\author{
UNIVERSIDADE DE SÃO PAULO \\ Faculdade de Filosofia, Letras e Ciências Humanas \\ Departamento de História \\ Programa de Pós-Graduação em História Social
}

\title{
O enigma da capital: \\ a mudança do vice-reinado para o Rio de Janeiro em 1763
}

Versão corrigida

Daniel Afonso da Silva

São Paulo

2012 


\section{O enigma da capital:}

a mudança do vice-reinado para o Rio de Janeiro em 1763 


\section{O enigma da capital:}

a mudança do vice-reinado para o Rio de Janeiro em 1763

Daniel Afonso da Silva

Estudo apresentado ao departamento de história da FFLCH-USP como demanda do curso de pós-graduação em História Social.

Nível: Doutorado

Orientação: Profa. Dra. Maria Inez Machado Borges Pinto (FFLCH-USP)

Direção no exterior: Prof. Dr. Lluis Ferran Toledano Gonzáles (Universitat Autònoma de Barcelona) e Prof. Dr. Luiz Felipe de Alencastro (Université de Paris 4 - Panthéon-Sorbonne) 
Estudo aprovado no dia 20 de abril de 2012 pela banca examinadora composta pela Profa. Dra. Maria Inez Machado Borges Pinto (FFLCH-USP), pelo Prof. Dr. Elias Thomé Saliba (FFLCH-USP), pelo Prof. Dr. João Luis Ribeiro Fragoso (IHUFRJ), pelo Prof. Dr. Antonio Carlos Robert Moraes (FFLCHUSP) e pelo embaixador Rubens Ricupero (FAAP e Itamaraty). 
Silva, Daniel Afonso da.

O enigma da capital: a mudança do vice-reinado para o Rio de Janeiro em 1763 / Daniel Afonso da Silva; Orientadora: Profa. Dra. Maria Inez Machado Borges Pinto - São Paulo, 2012.

\section{Estágios}

Universitat Autònoma de Barcelona - UAB Direção: Prof. Dr. Lluis Ferran Toledano Gonzáles.

Université de Paris 4 - Panthéon-Sorbonne Direção: Prof. Dr. Luiz Felipe de Alencastro.

Tese (doutorado) - Universidade de São Paulo, Faculdade de Filosofia, Letras e Ciências Humanas, Departamento de História.

Inclui:

Fontes e referências bibliográficas

Anexos

1. História - Tese. 2. Europa - Portugal - Brasil. 3. Rio de Janeiro - Bahia. 4. Diplomacia. 5. Administração.

I. Borges Pinto, Maria Inez Machado. II. Universidade de São Paulo. III. Título. 
O enigma da capital 


\section{Resumo}

O enigma da capital estuda a mudança do vice-reinado português da Bahia para o Rio de Janeiro em 1763. Contesta a tese da inevitabilidade dessa mudança. Relativiza a importância do Rio de Janeiro. Realça a importância da Bahia. Reafirma a centralidade de Lisboa na tomada de decisão. Apresenta cenários políticos e econômicos europeus e americanos do reinado do rei José e da gestão do secretário Sebastião compreendidos no período que recobre do tratado de Madrid de 1750 ao fim da guerra de sete anos em 1763. Enfatiza o concerto de alianças luso-inglesas e franco-espanholas. Acentua a influência dos diplomatas ingleses em Portugal. Reavalia a presença de enviados franceses e espanhóis em Lisboa. Recupera personagens capitais dessa diplomacia. Exibe figuras inglesas agudas e engenhosas como os embaixadores Abraham Castres e Edward Hay, os chanceleres Willian Pitt e conde de Egremont, o oficial James O’Hara, afamado lord Tyrawley. Expõe personalidades francesas decisivas como o conde de Merle, a madame Pompadour, o ministro Jacques O’Dunne, os chanceleres François-Joachim Pierre Bernis e Étienne-François Choiseul. Informa da relação conflituosa e cooperativa entre eles e os secretários do rei José. Indica a fina sintonia do secretário Sebastião com o embaixador Edward Hay. Lembra que trabalharam hand by hand durante os momentos decisivos da guerra. Reconhece a gravidade da guerra e sua difícil gestão do lado português. Relata como a onipresença de problemas europeus inviabilizou eventual participação mais ativa dos homens do rei José nas complicações americanas. Revalora a importância do governador Gomes Freire de Andrade, o conde de Bobadela. Diz de sua condição de confiado irrestrito da corte de Lisboa nas Américas. Fala de sua presença no contencioso Sacramento e de sua atuação como governador do Rio de Janeiro e do desolamento transcontinental que sua morte no início de 1763 causou. Propõe que a mudança da sede do vice-reinado para o Rio de Janeiro esteve em muito relacionada à sua morte. Leva em conta a força que o Rio de Janeiro ganhou com a exploração de ouro, mas demonstra a influência inabalável da Bahia nos séculos. Ressalta diferenças dessas duas capitanias. Defende que a decisão de mudar a capital para o Rio de Janeiro teve pouco ou nada que ver com possível "capitalidade" ou ainda intransponível importância adquirida pelo Rio de Janeiro. Suporta, com documentação administrativa e diplomática portuguesa, luso-brasileira, inglesa, francesa, espanhola, que houve absoluta indiferença no referente à mudança do lugar do vice-reinado no Brasil. Entende que a valorização do tema e do próprio Rio de Janeiro como capital inevitável foi construção histórico-ideológica dos séculos seguintes.

Palavras-chave: diplomacia, administração, colônia, Portugal-Brasil, Europa. 
Abstract

The enigma of capital does a study on the Portuguese viceroyalty capital change from Bahia to Rio de Janeiro in 1763. It contests the thesis of the inevitability of that change. It relativizes the importance of Rio de Janeiro. It stresses the importance of Bahia. It reaffirms the centrality of Lisbon in the decisionmaking. It presents political and economic European and American scenarios under King Joseph`s reign and the management of Under-Secretary Sebastian within a period that covers the treaty of Madrid in 1750 to the end of "seven years war" in 1763. It emphasizes the concert alliances LusoEnglish and French-Spanish. It emphasizes the influence of British diplomats in Portugal. It reassesses the presence of envoys from France and Spain in Lisbon. It recovers the importance characters of this diplomacy. It displays some sharp and witty English personages as ambassadors Abraham Castres and Edward Hay, the foreign ministers William Pitt and Earl of Egremont, Officer James O'Hara, the famous Lord Tyrawley. It exposes decisive French personalities as the Count de Merle, Madame Pompadour, Ambassador Jacques O'Dunne, the Chancellor Pierre Francois-Joachim Bernis and Étienne-François Choiseul. It tells the confrontational and cooperative relationship between them and the king Joseph's Under-Secretaries. It indicates the fine tuning of the Under-Secretary Sebastian to the ambassador Edward Hay. It remembers that they worked hand by hand during the decisive moments of the war. It recognizes the seriousness of war and its difficult to manage the Portuguese side. It relates how the omnipresence of European problems made it impossible for more active participation of King Joseph`s people due complications in America. It reevaluates the importance of Governor Gomes Freire de Andrade, Count of Bobadela. It says about his status as unrestricted and trustful inside the court of Lisbon in the Americas. It speaks of his presence in the Sacramento litigation and his performance as governor of Rio de Janeiro and the transcontinental desolation that his death caused in early 1763. It proposes that the change of the seat to viceroyalty in Rio de Janeiro was very much related to his death. It considers the force that Rio de Janeiro got with the exploration of gold, but it demonstrates the steady influence of Bahia in the centuries. It highlights differences in these two provinces. It argues that the decision to move the capital to Rio de Janeiro had little or nothing to do with possible "capitality" or insurmountable importance acquired by Rio de Janeiro. It supports, with Portuguese, Luso-Brazilian, English, French, Spanish administrative and diplomatic documentation, that there was complete indifference with regard to the change of place of the viceroyalty in Brazil. It believes that the valuation of the subject and Rio de Janeiro itself as the capital was inevitable historical and ideological construction of the following centuries.

Keywords: diplomacy, administration, colony, Portugal-Brazil, Europe. 


\section{Resumen}

El Enigma del capital estudia el cambio del vice-reinado portugués de Bahía para Rio de Janeiro en 1963. Contesta la tesis de lo inevitable de esos cambios. Relativiza la importancia de Rio de Janeiro. Destaca la importancia de Bahía. Reafirma un centralismo de Lisboa en la toma de decisiones. Presenta escenarios políticos e económicos europeo y americano del reino del rey José y de la gestión del secretario Sebastião comprendidos en el periodo que cubre el tratado de Madrid de 1950 al fin de la guerra de siete años en 1963. Enfatiza el acuerdo de alianzas luso-inglesas e franco-españolas. Hace hincapié la influencia de los diplomáticos ingleses en Portugal. Reevalúa la presencia de enviados franceses y españoles en Lisboa. Se recupera personajes capitales de esa diplomacia. Expone figuras inglesas agudas e ingeniosas como los embajadores Abraham Castres e Edward Hasy, los cancilleres Willian Pitt y conde de Egremont, el oficial James O'Hara, famoso lord Tyrawley. Muestra personalidades francesas decisivas como el conde de Merle, la madame Pompadour, el ministro Jacques O'Dunne, los cancilleres Françõis-Joachim Pierre Bernis e Étienne-François Choiseul. Informa la relación de conflicto y de cooperación entre ellos y los secretarios del rey José. Indica una fina sintonía del secretario Sebastião con el embajador Edward Hay. Recuerda que trabajan hand by hand durante los momentos decisivos de la guerra. Reconoce la gravedad de la guerra y su difícil gestión del lado portugués. Relata como la omnipresencia del problema europeo inviabilizo eventual participación activa de los hombres del rey José en las complicaciones americanas. Reevalúa la importancia del gobierno Gomes Freire de Andrade, el conde de Bobadela. Expresa de su condición de confiado irrestricto de la corte de Lisboa en las Américas. Habla de su presencia en el litigio sacramento y de su actuación como gobernador de Rio de Janeiro y del disgusto transcontinental de su muerte a inicio de 1763. Propone que el cambio de la sede del vice-reinado para Rio de Janeiro estuvo muy relacionado a su muerte. Valoriza la fuerza que Rio de Janeiro gano con la explotación de oro, pero demuestra una influencia firme de Bahía en los siglos. Enfatiza diferencias de esas dos capitanías. Defiende la decisión de cambiar la capital para Rio de Janeiro teniendo poco o nada que ver con un posible capitalismo o una insoportable importancia adquirida por Rio de Janeiro. Soporta, con documentación administrativa y diplomática portuguesa, luso-brasilera, inglesa, francesa, española, que tuvo absoluta indiferencia referente al cambio de lugar del vice-reinado en Brasil. Entiende que la valorización del tema en si y de Rio de Janeiro como capital inevitable fue la construcción histórico-ideológica de los siglos posteriores.

Palabras claves: Diplomacia, administración, colonia, Portugal-Brasil, Europa. 
Para minha avó. 
L'histoire est fille du récit. Elle n'est pas définie par un objet d'étude, mais par un type de discours. Dire qu'elle étudie le temps n'a en effet pas d'autre sens que de dire qu'elle dispose tous les objets qu'elle étudie dans le temps: faire de l'histoire c'est raconter une histoire.

François Furet, L'Atelier de l'historien. 


\section{Sumário}

\section{Prólogos}

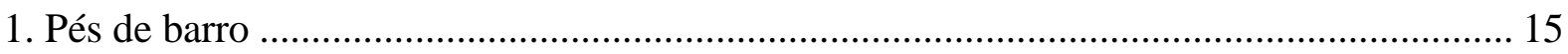

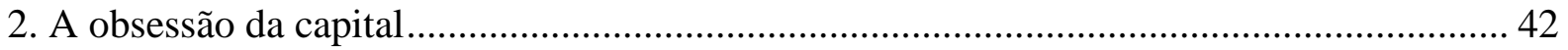

\section{Parte I - Sonâmbulos}

3. Depois que os sinos dobram.

\section{Parte II - Insones}

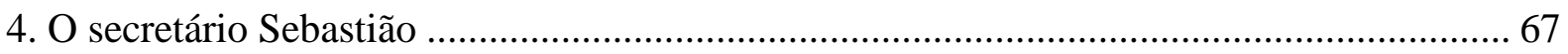

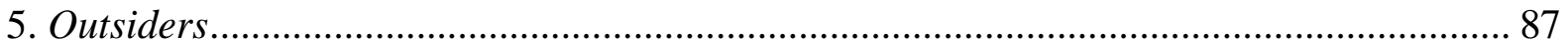

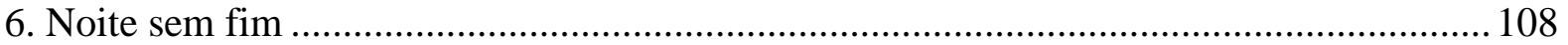

\section{Parte III - Os sentidos da capital}

7. Cidades

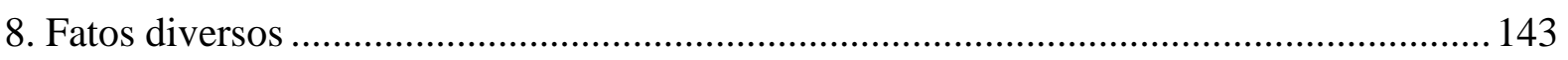

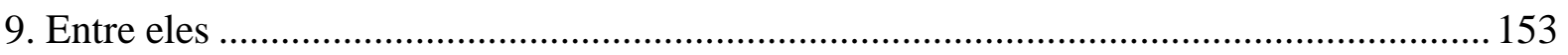

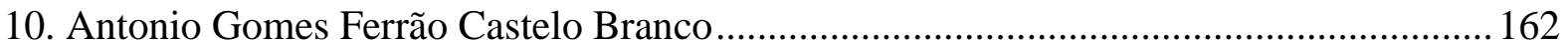

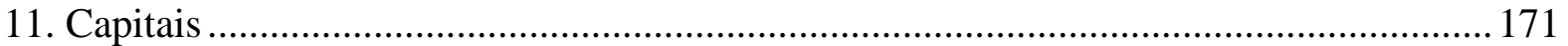

\section{Epílogo}

12. A ubiquidade do memento more

Fontes e referências bibliográficas

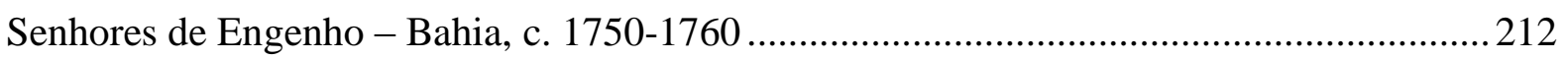

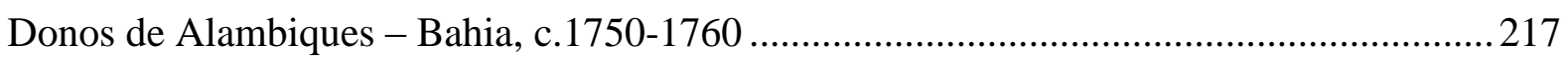

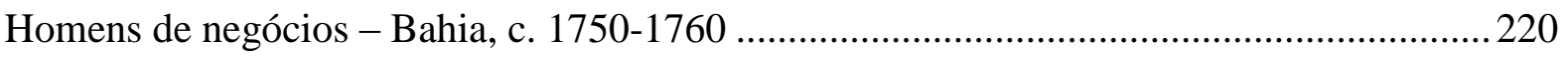


Siglas e abreviações

AHU - Arquivo Histórico Ultramarino

AMU - Arquivo Marítimo Ultramarino

BNRJ - Biblioteca Nacional do Rio de Janeiro

DH - Documentos Históricos

RIHGB - Revista do Instituto Histórico e Geográfico Brasileiro

SCMBA - Santa Casa de Misericórdia da Bahia

State Paper Foreing, The National Archives, Mémoires et documents e Archives du ministère des affaires étrangères seguem sem abreviação nem tradução. 
Prólogos 


\section{Pés de barro}

Quem ríe, entiende.

Pablo Neruda

Uma árvore geme se a cortam, um cão cane se lhe batem, um homem cresce se lhe ofendem.

José Saramago, $O$ evangelho segundo Jesus

Cristo, p. 324.

Life's but a walking shadow, a poor player That struts and frets his hour upon the stage And then is heard no more: it is a tale Told by an idiot, full of sound and fury, Signifying nothing.

Willian Shakespeare, Macbeth (V, 5)

Brasil, agosto-setembro de 1763. Autoridades de todas as capitanias receberam a notícia de que o Rio de Janeiro seria a nova capital. Sede do vice-reinado. Casa do vice-rei. Nenhuma lágrima vazou de olhos baianos. Nenhum sorriso, mesmo que mudo e zombeteiro, estampou rostos fluminenses. Comentário algum mereceu lugar em Lisboa. Muito menos em Paris, Londres, Madrid ou Buenos Aires. Indiferença absoluta envolveu a decisão e sua recepção. A vida seguiu seguindo como sempre seguiu na São Salvador da Bahia de Todos os Santos. Nada mudou no cotidiano de homens e mulheres que na cidade do Rio de Janeiro lutavam para ganhar seu pão. De sul a norte, ninguém entendeu esse acontecimento como extraordinário. Ou minimamente portador de alguma importância. Fosse política, identitária, estratégica, econômica, militar ou social. O silêncio foi ensurdecedor. A cidade da Bahia, a São Salvador, continuou o núcleo de peregrinação ao norte. Mesmo convivendo com intensa e já eterna rivalidade com Pernambuco. Mesmo estando muito longe da Amazônia, do Maranhão, do Grão-Pará. A cidade do Rio de Janeiro, capital de capitanias, seguiu núcleo ao 
sul. A despeito da impressão concreta de vazio e dispersão de Mariana a Goiânia a Santos a Curitiba a Sacramento. Antonio Álvares da Cunha, o conde da Cunha, enviado ao Rio de Janeiro como vice-rei do estado do Brasil, simbolizaria, por certo, o Brasil, mas responderia não muito mais que pela capitania onde iria residir. Fôra assim com seus predecessores na Bahia. Seria assim com um e outro que lhe faria suceder no Rio de Janeiro. O rei José sabia disso. Seus secretários também. O dr. Sebastião muito especialmente. A unidade do domínio Brasil existia somente no mapa. O mapa, agora, das cortes, de 1748-9. Preocupavam em nada mercadores luso-brasileiros em Portugal em Áfricas em Índias ser a capital na Bahia ou no Rio de Janeiro, no Rio Grande de São Pedro ou em Olinda-Recife. Corsários, piratas e inimigos também não faziam questão. O responsável pelo conselho ultramarino jamais tratara diferentemente os vassalos de sua majestade seu soberano nas Américas por serem estes vicereis, governadores, ouvidores ou capitães-mores. Conquanto sempre tenha sido evidente a importância da hierarquia e da liturgia das funções e das ações. Ser capitão-mor ou ser ouvidor ou ser governador, no mesmo espaço de abrangência, tinha pesos claramente desiguais. Mesmo que em certos casos essas medidas fossem invertidas. Não raro, ser governador e ser vice-rei punha em dúvida as reais dimensões e extensão do poder. Não deve de ter sido fácil ser vice-rei na Bahia enquanto o ouro jorrava em foz nos portos do Rio de Janeiro e os louros iam direto para o governador geral da capitania fluminense. Alguma tensão, na forma de insubordinação, existiu. Que não se subestime isso. A superioridade absoluta do responsável do domínio inteiro - entendam-se os estados do Brasil e do Maranhão e Grão-Pará - só iria ganhar consistência quando se afirmasse a consciência e o sentimento coletivo de coexistência e pertencimento à mesma barca. À mesma comunidade. Ao mesmo Brasil. Não foi em 1763 que isso ocorreu. Tampouco nos anos magros e modorrentos que se seguiram. Os ventos sopravam de fora e desde muitas partes. La fin-de-siècle deu sinais fortes. Indicativos. Decisivos. Decisórios. O desconjuntamento do que se convencionou chamar de ancien régime somado a contestações veementes aos pactos metrópoles-colônias anunciou a distensão e o novo diapasão. Nada e nem ninguém resistiram inertes ao verão de 1776 desde a Filadélfia. The American Revolution marcou profundamente as estruturas do cotidiano e le temps du monde. O reino unido da Grã-Bretanha jamais foi o mesmo. Não foi diferente o impacto e a veemência do verão de 1789 desde Paris. Cidadãos, em ciranda, fizeram sua manifestação, sua execução, sua realização, sua revolução. O povo pobre, como aventou e acertou o sátiro Réstif, descobriu enfim que era pobre e não filho do rei. Nenhuma cabeça de santo nos cumes de igrejas ficou sobre seus pescoços em Lyon, Marseille, Toulouse, Nice, Nantes, Toulon. Depois do 21 de julho de 1791, em Varennes-en-Argonne, 
na Lorena, rumos aos limites da França, nem mesmo a do rei Louis Auguste e de seus próximos foram poupadas. As imagens, os suspiros, as excitações, as dúvidas, as esperanças, as ilusões que sucederam essa dramática e sombria nuit de Varennes atravessaram fronteiras por terra e mar, bocas e ouvidos, com velocidade extraordinariamente exemplar. ${ }^{1} \mathrm{De}$ Washington a Buenos Aires a Coimbra a Dublin a Dover a Istambul a Curaçao a Nanquim a Varsóvia a percepção material do esgotamento e do paulatino desaparecimento de um tipo de civilização ficou flagrante. Os old regimes passavam a fortemente claudicar. A indústria, a triunfar. Não sem resistência. Não em instantâneo. Não sem forças do contra. A burguesia liberal foi se afirmando. Mesmo com as agudas permanências do statu quo ante. A geoeconomia mundial se redesenhou. Mesmo com diversa e efusiva dificuldade. 20, 30 anos antes, pelos 1750s, 1760s, 70\% da população do mundo estava submetida ao campo. Aos agrarian empires. Qing na China, Mughal na Índia, Tokugawa no Japão, Safavid no Irã, os espaços ottomano e russo e da monarquia Habsburg somados aos ibéricos davam o tom. Sofisticadas e rebuscadas modalidades de autoridade política, religiosa e cultural dependentes de economia singelamente baseada em agricultura eram os ingredientes da concreta realidade global e particular. Economia-agricultura contingente. Suscetível à natureza. Ao meio ambiente. À ecologia, à biosfera. Sol e chuva. E todos os insondáveis caprichos do clima geridos por mistérios de Deus ou deuses. ${ }^{2}$ Nessa global old order, mais de dois terços das pessoas eram ou escravos ou servos. Milhões de homens, mulheres e crianças trabalhavam incessantemente. Muita vez intimados por chicotes e intimidados por açoites. Muita vez mais de 14 horas por dia. Sempre sem nada receber. Forçados a viver muito malmente. A sobreviver com dificuldades. Muita vez sem nenhum mísero naco seco de pão. Mesmo com o excessivo suor saído de seus rostos. No mundo islâmico se escravizou. No ottomano se escravizou. Na Rússia se escravizou e se impôs a servidão. Na Índia e em várias partes da Ásia, milhões de trabalhadores eram escravos. Instrumentum vocale. Ora por dívida. Ora pelo azar de pertencer a reino vencido. Durante e depois da grande expansão transatlântica dos quatrocentos-quinhentos, o novo mundo se mostrou, convém crer, apenas adendo nessa história. Não por ser desprezível ou desprezável. Justo pelo contrário. Foi aí que o infame e imundo comércio mais sistematicamente revelou a face abominável do medonho sistema.

\footnotetext{
${ }^{1}$ Simon SCHAMA - Citizens: a chronicle of the French Revolution. New York: Alfred A. Knopf, 1990. Alexis de TOCQUEVILlE - De la démocratie en Amérique. Paris: Gallimard, 1961. Fernand BRAUDEL Grammaire des civilisations. Paris: Les Éditions Arthaud, 1987. Giovanni ARRIGHI - O longo século XX. Dinheiro, poder e as origens de nosso tempo. Trad. Vera Ribeiro. Rio de Janeiro: Contraponto, 1996. Niall FERGUSON - A lógica do dinheiro. Trad. Maria Teresa Machado. Rio de Janeiro: Record, 2007. Ettore SCOLA - La nuit de Varennes. Paris-Roma, 1982. 150min.

2 C. A. BAYLY - The birth of modern world 1780-1914. Global connections and comparisons. Oxford: Blackwell Publishing, 2005. pp. 27-34.
} 
Gerações e gerações de africanos só conheceram na vida prisão. Compulsão. O ingrato ofício de ser coisa de outro alguém. ${ }^{3}$ Séculos e séculos de confisco de seus sonhos e esperanças fizeram o Atlântico ficar negro. Virar espaço comum de negras memórias de gente negra arrancada de suas negras estruturas de sentimento, produção, comunicação e memória. ${ }^{4}$ Dezenas de milhares de peles e almas negras foram embarcadas, em média, nos áureos sórdidos anos, em tumbeiros para a morte. Os números globais desse crime são computados em milhões de pessoas em quatrocentos anos. ${ }^{5} \mathrm{O}$ açúcar, especialmente legado e dependente do trabalho da gente das Áfricas, cegou o bom-senso dos homens brancos europeus. Desde meados dos seiscentos, o produto açúcar - em decorrência, o negócio de fazendas de açúcar se afirmou o primeiro produto básico mundo afora. A primeira mercadoria sobre a base de valor das transações de comércio internacional. ${ }^{6}$ Plantations e plantations se transformaram nos desejos insuspeitos mais imponentes da gente de Europa. A realização desses anseios se deu com sangue negro. Não apenas nas sugar islands. Muito menos somente no Caribe onde o tratamento aos vindos das Áfricas era simplesmente inimaginavelmente brutal. Mas de Baltimore ao Rio de Janeiro a Buenos Aires. Milhões de seres foram arrancados, majoritariamente, do Senegal para a Virgínia. Da Serra Leoa para Charleston. Do delta do rio Níger para Cuba. De Angola para o Brasil. ${ }^{7}$ De 1660 em diante, a voracidade da expansão desse vil negócio da escravidão só fez, e faz, impressionar. De 1760, 1770, o impressionante foi seu retrocesso. O vácuo 1763-1776-1789 tornou a prática vez ilegal, vez inviável, imoral.

\footnotetext{
${ }^{3}$ Adam HOCHSCHILD - Enterrem as correntes. Profetas e rebeldes na luta pela libertação dos escravos. Trad. Wanda Brant. Rio de Janeiro: Record, 2007. pp. 12-3.

${ }^{4}$ Paul GILROY - O Atlântico negro. Modernidade e dupla consciência. Trad. Cid Knipel Moreira. São Paulo: 34, 2008. pp. 35 ss.

${ }^{5}$ Pesquisas mais recentes sugerem os números a seguir.
}

\begin{tabular}{|l|r|r|r|r|r|r|r|r|}
\hline & $\begin{array}{r}\text { Espanha } \\
\text { Rio da Prata }\end{array}$ & $\begin{array}{r}\text { Portugal } \\
\text { Brasil }\end{array}$ & Grã-Bretanha & Holanda & Estados Unidos & França & Bálticos & Totais \\
\hline $1501-1550$ & 31,738 & 32,387 & 0 & 0 & 0 & 0 & 0 & $\mathbf{6 4 , 1 2 6}$ \\
\hline $1551-1600$ & 88,223 & 121,804 & 1,922 & 1,365 & 0 & 66 & 0 & $\mathbf{2 1 3 , 3 8 0}$ \\
\hline $1601-1650$ & 127,809 & 469,128 & 33,695 & 33,558 & 824 & 1,827 & 1,053 & $\mathbf{6 6 7 , 8 9 3}$ \\
\hline $1651-1700$ & 18,461 & 542,064 & 394,567 & 186,373 & 3,327 & 36,608 & 26,338 & $\mathbf{1 , 2 0 7 , 7 3 8}$ \\
\hline $1701-1750$ & 0 & $1,011,143$ & 964,639 & 156,911 & 37,281 & 380,034 & 10,626 & $\mathbf{2 , 5 6 0 , 6 3 4}$ \\
\hline $1751-1800$ & 10,654 & $1,201,860$ & $1,580,658$ & 173,103 & 152,023 & 758,978 & 56,708 & $\mathbf{3 , 9 3 3 , 9 8 5}$ \\
\hline $1801-1850$ & 568,815 & $2,460,570$ & 283,959 & 3,026 & 111,395 & 203,890 & 16,316 & $\mathbf{3 , 6 4 7 , 9 7 1}$ \\
\hline $1851-1866$ & 215,824 & 9,309 & 0 & 0 & 476 & 0 & 0 & $\mathbf{2 2 5 , 6 0 9}$ \\
\hline Totais & $\mathbf{1 , 0 6 1 , 5 2 4}$ & $\mathbf{5 , 8 4 8 , 2 6 5}$ & $\mathbf{3 , 2 5 9 , 4 4 0}$ & $\mathbf{5 5 4 , 3 3 6}$ & $\mathbf{3 0 5 , 3 2 6}$ & $\mathbf{1 , 3 8 1 , 4 0 4}$ & $\mathbf{1 1 1 , 0 4 1}$ & $\mathbf{1 2 , 5 2 1 , 3 3 6}$ \\
\hline
\end{tabular}

Fonte: http://www.slavevoyages.org/tast/assessment/estimates.faces

\footnotetext{
${ }^{6}$ Manuel Moreno FRAGINALS - El ingenio. Complejo económico social cubano del azúcar. Barcelona: Crítica, 2001. p. 11.

${ }^{7}$ Adam HOCHSCHILD - Enterrem as correntes, op. cit., pp. 12 ss.
} 
Foi nesse momento que os preceitos nascidos na Europa começaram a dominar o mundo para além da Europa e para além dos domínios dos europeus. Mas, sobretudo, neles, Europa e domínios, especialmente. França e Reino Unido se afirmaram efetivamente os donos do mundo. Cada qual à sua maneira, na economia e na ideologia, saíram na frente no século XVII e chegaram primeiro nos fins do XVIII. Mesmo com perdas. Duras perdas. Mas foram dessas e por essas perdas - especialmente os Estados Unidos da América e a cabeça do rei Louis XVI e da austríaca dona Maria Antonieta, madame déficit segundo o povo - que surgiram como l'avant-garde dos novos tempos. Em essência, o balance of power e la raison d'État, nocauteados na guerra dos sete anos, 1756-1763, chegaram a rotação perigosa. ${ }^{8}$ Nunca antes cogitada. Foram criadas novas ideias e novos atores. Estado, nação, minoria étnica, ciência, trabalho livre surgiram ou foram metamorfoseados e impostos em casa e no exterior. ${ }^{9}$ Nem sempre sem risco. Quase nunca com controle. Os incomodados começaram a fazer os antiquados se mudar. Especialmente no já velho novo mundo. Os homens de L'Overture fizeram os franceses sumir para o além-mar. Ou simplesmente para o além. Os homens de Junot tentaram fazer o mesmo com os portugueses. Mas conseguiram apenas parte do que queriam. Dom João fugiu para o Brasil e fez do Rio de Janeiro um ambiente singular. ${ }^{10}$

\footnotetext{
${ }^{8}$ Henry KISSINGER - Diplomacy. New York: Simon \& Schuster Paperbaks, 1994. Caps. 1, 2 e 3. Hannah ARENDT - Da revolução. Trad. Fernando Dídimo Vieira. Brasília: Editora da UnB, 1988. Sofia COPOLA Marie Antoinette. EUA-França-Japão, 2006. 123 min.

${ }^{9}$ C. A. BAYLY - The birth of modern world 1780-1914, op. cit., p. 36. Benedict ANDERSON - Introdução. In.: Gopal BALAKRISHNAN - Um mapa da questão nacional. Trad. Vera Ribeiro. Rio de Janeiro: Contraponto, 2000. Benedict ANDERSON - Nação e consciência nacional. Trad. Lólio Lourenço de Oliveira. São Paulo: Ática, 1989. Geoff ELEY \& Ronald Grigor SUNY - Introduction: from the moment of social history to the work of cultural representation. In.: Geoff ELEY - Becoming national. A reader. Oxford: Oxford University Press, 1996. Pierre VILAR - Estat, Nació, Socialisme. Estudis sobre el cas espanyol. Barcelona: Curial, 1981. Liah GREENFELD - Nacionalismo. Cinco vías hacia la modernidad. Trad. Jesús Cuéliar Menezo. Madrid: Centro de Estúdios Políticos y Constitucionales, 2005. Reinhart KOSELLECK Futuro Passado: contribuição à semântica dos tempos históricos. Trad. Wilma Patrícia Maas e Carlos Almeida Pereira. Rio de Janeiro: Contraponto, 2006. Marcus Vinicius MAZZARI - Apresentação. In.: Johann Wolfgang GOETHE GOETHE - Os anos de aprendizado de Wilhelm Meister. São Paulo: 34, 2006. Norbert ELIAS - A sociedade de corte. Trad. Ana Maria Alves. Lisboa: Estampa, 1987. Norbert ELIAS - O processo civilizador. Trad. Rui Jungmann. Rio de Janeiro: Jorge Zahar, 1994. Hans Peter DUERR - Nudez e pudor. O mito do processo civilizacional. Lisboa: Editorial Notícias, 2002. Michael BILLIG - Banal nacionalism. Londres: Sage, 1995. Josep R. LLOBERA - El dios de la modernidade. Barcelona: Anagrama, 1994.

${ }^{10}$ Eric HOBSBAWM - A era das revoluções. Europa 1789-1848. Trad. Maria Tereza Lopes Teixeira e Marcos Penchel. 16. ed. São Paulo: Paz e Terra, 2002. Robin BLACKBURN - The overthrow of colonial slavery, 1776-1848. Londres: Verso, 2011. C. L.R. JAMES - The Black Jacobins: Toussaint L'Ouverture and the San Domingo Revolution. Londres: Allison and Busby Limited, 1980. Laurentino GOMES - 1808: como uma rainha louca, um príncipe medroso e uma corte corrupta enganaram Napoleão e mudaram a história de Portugal e do Brasil. São Paulo: Planeta, 2007. Lilia Moritz SCHWARCZ; Angela Marques da COSTA; Paulo Cesar de AZEVEDO - A longa viagem da biblioteca dos reis: do terremoto de Lisboa à independência do Brasil. São Paulo: Companhia das Letras, 2002.
} 
A interiorização da metrópole foi de fato um fato. ${ }^{11}$ Nenhum comentário, por mais sagaz e ardiloso, o pode obliterar. A transmigração do rei João e de sua corte para o Rio de Janeiro mudou desconsertantemente a geografia das percepções. Os colonos, mesmo tornados brasílicos no espaço americano, finalmente deixaram de projetar sua devoção para fora do Brasil. O Rio de Janeiro foi se tornando o centro natural da romaria da identificação. O farol do Brasil passou a lançar sua luz dessa cidade. Mesmo já sem tanto ouro. A força alucinante dessa lanterna impôs unidade jamais vista aos territórios e aos corações na porção Brasil das Américas. Quando não voluntária, pela fatura do fisco. ${ }^{12}$ Quando não entusiasmada, pelo recrutamento mais e mais forçado. Quando com impertinente resistência, com o degredo. Quando com obstinada objeção, com, por vezes, singela missa pós-féretro a expensas, quando sobrava, de algum vivente da família. Nada competia com a soberania soberana do soberano. Unidade e soberania foram definindo o sentido da capital. A importância verdadeiramente real da cidade do Rio de Janeiro. Pois somente esses dois predicados foram impondo a necessidade de reconhecimento do centro como central. Do fortemente central como capital. E, portanto, do Rio de Janeiro, morada do rei, como efetiva cidade-central-capital. Nada disso ocorreu antes da corte rumar para o exílio. ${ }^{13}$

A sanguinária devassa que as medidas da rainha Maria insuflaram nas Minas Gerais depois de 1777 e os conturbados acontecimentos que conduziram às execuções de 8 de novembro de 1799 na praça da Piedade na cidade da Bahia incluíam o Brasil na sintonia dos movimentos que estavam mudando o mundo. ${ }^{14}$ Prenúncio do exílio do rei. O grito dos decapitados se fazia ouvir nos extremos dos territórios de Portugal. O inexprimível dos massacres seguia ouvido e boca como notícia e exemplo. Ninguém do comum era indiferente à dor e insensível ao terror. A tomada de consciência dessa situação foi fazendo germinar a consciência da mudança. Os baianos, paulistas, pernambucanos que se sentiam genuinamente portugueses começaram a se querer e se afirmar, sem arroubos apressados, cada vez mais e mais brasileiros. A aceleração do tempo histórico nesses momentos despiu a apatia da

\footnotetext{
${ }^{11}$ Maria Odila Leite da Silva DIAS - A interiorização da metrópole e outros ensaios. 2. ed. São Paulo: Alameda, 2009. pp. 7-37.

${ }^{12}$ Wilma PERES - Do domínio à nação: os impasses da fiscalidade no processo de Independência. In.: István JANCSÓ - Brasil: formação do Estado e da Nação. São Paulo: Hucitec, 2003.

${ }^{13}$ Maria Odila Leite da Silva DIAS - A interiorização da metrópole e outros ensaios, op. cit., pp. 7-37. Jurandir MALERBA - A corte no exílio: civilização e poder no Brasil às vésperas da independência (1808-1821). São Paulo: Companhia das Letras, 2001. Flora LAHUERTA - Geografias em movimento: território e centralidade no Rio de Janeiro (1808-1821). São Paulo, 2010. (Dissertação apresentada ao departamento de Geografia da FFLCH-USP)

${ }^{14}$ Kenneth MAXWELL - A devassa da devassa. A Inconfidência Mineira. Brasil e Portugal (1750-1808). 5. ed. São Paulo: Paz e Terra, 2000. István JANCSÓ - Na Bahia, contra o Império. História do ensaio de sedição de 1798. São Paulo: Hucitec, 1996.
} 
aparente imobilidade dos dias. A fúria dessas contradições irromperia, para além da metropolização da colônia, o processo de separação e independência. ${ }^{15}$

Não houve consenso ou gradualismo absoluto na adoção de decisões. Tudo foi perdendo a espontaneidade. Tudo foi ficando anacrônico. Desfocado. Desbotado. A negação de Portugal e a afirmação do Brasil imprimiram em ações concretas a exaustão de um pacto, de uma aliança, de um destino manifesto que num passado não tão distante ainda eram vividos como eternais. O banimento da condição de colonial reforçou a necessidade de se construir uma nacional. O Estado nacional brasileiro, nucleado no Rio de Janeiro, mesmo sem povo, foi se consolidando em autonomia e poder e representação e unidade. A longa viagem para o reconhecimento dessa consolidação ultrapassaria os séculos seguintes. Não poucos acreditamos que essa viagem segue incompleta. ${ }^{16} \mathrm{E}$ é nessa incompletude que se conspurca o que realmente faz do Brasil, Brasil.

Indagação ou preocupação nenhuma desse porte e calibre povoaram os pensamentos e os cotidianos do rei José e do secretário Sebastião ${ }^{17}$ ao fazerem mudar a sede do vice-reinado da Bahia para o Rio de Janeiro em 1763. Mas segue imperativo indagar as razões que conduzem parte majoritária dos analistas a acreditar e reiterar o caráter providencial da nova sede e o aspecto trágico e desastroso da antiga. Questionar essa tendência e melhor problematizar os pretextos da mudança da capital consiste no objetivo de tudo que prossegue.

\footnotetext{
${ }^{15}$ Caio PRADO JR. - Formação do Brasil Contemporâneo. Colônia. São Paulo: Publifolha, 2000. Fernando A. NOVAIS - Portugal e Brasil na Crise do Antigo Sistema Colonial. 8. ed. São Paulo: Hucitec, 2005. István JANCSÓ \& João Paulo G. PIMENTA - Peças de um mosaico (ou apontamentos para o estudo da emergência da identidade nacional brasileira). In.: Carlos Guilherme MOTA - A viagem incompleta. A experiência brasileira (1500-2000). Formação: Histórias. São Paulo: Senac, 2000.

${ }^{16}$ Carlos Guilherme MOTA - A viagem incompleta. A experiência brasileira (1500-2000). Formação: Histórias. São Paulo: Senac, 2000. Carlos Guilherme MOTA - A viagem incompleta. A experiência brasileira (15002000). A grande transição. São Paulo: Senac, 2000. João Cezar de Castro ROCHA - "Nenhum Brasil existe”: poesia como história cultural. In.: João Cezar de Castro ROCHA (Org.) - Nenhum Brasil Existe. Pequena Enciclopédia. Rio de Janeiro: Topbooks, 2003. Roberto DAMATTA - Carnavais, Heróis e Malandros: para uma sociologia do dilema brasileiro. Rio de Janeiro: Guanabara, 1990. Gilberto FREYRE - Casa-Grande \& Senzala. Formação da família brasileira sob o regime da economia patriarcal. 51. ed. São Paulo: Global, 2006. Gilberto FREYRE - Sobrados e mucambos. Decadência do patriarcado rural e desenvolvimento urbano. Edição comemorativa de 70 anos. São Paulo: Global, 2006. Sérgio Buarque de HOLANDA - Raízes do Brasil. Edição comemorativa de 70 anos. Ricardo Benzaquen de Araújo e Lília Moritz Schwarcz organizadores. São Paulo: Companhia das Letras, 2006.

17 Ao longo de todo o texto tratarei o dr. Sebastião José de Carvalho e Melo, conde de Oeiras e marquês de Pombal, por secretário Sebastião. Isso poderá parecer afrontoso para os que sempre o conheceram pelos títulos de conde ou marquês. Entretanto, minha escolha tem por intuito fugir de comum tendencioso anacronismo. Na maior parte do recorte temporal analisado, 1750-1763, Sebastião José de Carvalho e Melo não era nem conde, nem marquês. Utilizo, portanto, a designação do que realmente ele era à época: secretário: secretário Sebastião.
} 
O mainstream considera e apoia e defende a inevitabilidade da transferência da sede do vice-reinado para o Rio de Janeiro. Parece ter sido Francisco José de Oliveira Vianna, por volta de 1920, o primeiro a chegar ao esquema interpretativo perfeito que sugere que o Rio de Janeiro capital nos sessentas dos setecentos expressava e era a expressão da oportuna e necessária alteração "do centro de gravidade econômica e militar" do domínio Brasil. ${ }^{18} \mathrm{O}$ ouro das minas e as fronteiras de Sacramento eram, por assim dizer, em seu ideário, a justificativa pura e simples para a mudança. O metal amarelo que saia dos portos fluminenses e o contencioso ao sul estavam milhas mais próximos dali que da Bahia. A força da explicação convenceu. Virou obviedade. Verdade. Prova inconteste. Pedro Octavio Carneiro da Cunha, em dois capítulos do tomo $1^{\circ}$, volume $2^{\circ}$ da História da civilização brasileira de Sérgio Buarque de Holanda, reconsiderou e reforçou a medida de Oliveira Vianna. Em Política e administração de 1640 a 1763 coordenou a avaliação de modo a valorizar a crescente centralidade do Rio de Janeiro em detrimento das demais capitanias no pósrestauração. ${ }^{19}$ Em Política e administração sob os últimos vice-reis sua tônica recaiu sobre a sapiência do secretário Sebastião em implantar política que condicionasse eficaz "geometria do poder". O Rio de Janeiro capital, informa Pedro Octavio, tinha sido o ponto agudo dessa intenção. $^{20} \mathrm{O}$ refinamento insuspeito e total dessa interpretação veio e vem com os importantes e decisivos estudos de Maria Fernanda Baptista Bicalho. Seu belo A cidade e o império virou obra absoluta para quem acredita no esquema de Oliveira Vianna. Quer dizer, de um modo ou de outro, todo mundo. Com esmerado requinte e singular densidade expositiva, Maria Fernanda plasmou a história do Rio de Janeiro à do império português em imensa tensão com os interesses das potências europeias dos setecentos. Como altas e pesadas doses de documentação portuguesa e francesa, e um e outro suposto de história da Inglaterra, a grandeza eternal e providencial do Rio de Janeiro transpira nas realmente muito bem escritas páginas do livro de Maria Fernanda. Capítulo a capítulo a persuasão vai se impondo implacável. "A cidade do medo", que encarna a situação do Rio de Janeiro, só o foi, ora insinua ora ratifica Maria Fernanda, por ter sido, a cidade do Rio de Janeiro, desproporcionalmente importante. ${ }^{21}$ Essa extraordinária importância conduziu Maria

\footnotetext{
${ }^{18}$ Francisco José de Oliveira VIANNA - Populações meridionais do Brasil. História, organização e psicologia. Populações rurais do centro sul. Paulistas, fluminenses, mineiros. Belo Horizonte: Itatiaia, 1987. pp. 206 ss.

${ }^{19}$ Pedro Octavio Carneiro da CUNHA - Política e administração de 1640 a 1763. In.: Sérgio Buarque de HOLANDA - História da civilização brasileira. 1. A época colonial. 2. Administração, economia, sociedade. Rio de Janeiro: Bertrand Brasil, 1997.

${ }^{20}$ Pedro Octavio Carneiro da CUNHA - Política e administração sob os últimos vice-reis. In.: Sérgio Buarque de HOLANDA - História da civilização brasileira, op. cit., pp. 355ss.

${ }^{21}$ Maria Fernanda BICALHO - A cidade e o império. O Rio de Janeiro no século XVIII. Rio de Janeiro: Civilização Brasileira, 2003.
} 
Fernanda a formular uma teoria da capitalidade para o Rio de Janeiro que, dito sem meias palavras, postula que dada a importância da cidade, não teria jeito: mais menos dia, seria capital. $^{22}$

Saindo da comodidade do esquema e da harmonia do consenso, as certezas do que pareceu inevitavelmente incontornável vão perdendo em substância. No canteiro das evidências, apenas um e outro sinal recobre diretamente o caso. Mas nada o sustenta. Apenas destaca e informa que houve decisão. O rastro mais eloquente - encontrado e analisado por Maria Fernanda especialmente, e que vou reanalisar adiante - é a própria carta que porta a decisão. Ou seja, o documento que nomeou o conde da Cunha vice-rei e definiu que sua casa seria no Rio de Janeiro. A tensão com o mainstream pode ser deduzida pela maneira que se compreendeu, eles compreenderam e eu tento compreender, essa decisão e seus supostos.

Pelo estudo inteiro que vou aqui tentando anunciar, seguirei caminhando, reforçando e apanhando dessa tensão. Não é fácil contrariar obsessões. Sempre é inglório marchar contra elas. Mas segue primordial pô-las continuamente em exame. N'A obsessão da capital, capítulo seguinte, vão, com mais ênfase, os elementos que justificam a minha reação. Resta aqui realçar o que parece o mais particular no enquadramento geral da abordagem: o ouro e Sacramento.

Ouro e Sacramento dão substância à tese da "mudança do centro de gravidade". Ou seja, à tese da inevitabilidade da mudança da capital. Entretanto, possivelmente, na cabeça dos homens de Lisboa, especialmente na do secretário Sebastião, esse ouro e esse Sacramento não passavam de gigantes de pés de barro.

Seria onanismo mental criminoso negar a importância do ouro e das minas e de Sacramento rota de minas. Ouro (e prata), como ensina Marx n'O capital, era, antes e acima de tudo, dinheiro. "Mercadoria que funciona como medida de valor e também, corporalmente ou por intermédio de representantes, como meio circulante". Sua posse, por si só, era expressão social de excedente e riqueza. ${ }^{23}$ A velha Sérvia, os Alpes, a Sardenha, a Etiópia, Solafa, Egito, Schwaz no vale do Inn, Neushol na Hungria, Mansfel na Saxe, Kuttenberg no

\footnotetext{
${ }^{22}$ Maria Fernanda BICALHO - As noções de capitalidade no Rio de Janeiro sob a política pombalina. In.: Ana Cristina ARAÚJO; José Luis CARDOSO; Nuno Gonçalves MONTEIRO et all (Org.). O terremoto de 1755: impactos históricos. Lisboa: Livros Horizonte, 2007.

${ }^{23}$ Karl MARX - O capital. Crítica da economia política. 1. O processo de produção do capital. Trad. Regis Barbosa e Flávio R. Kothe. São Paulo: Abril Cultural, 1983. pp. 107-11.
} 
entorno de Praga, Erz Gebirge, tudo antes das Américas, alimentaram todo o Mediterrâneo de prata e ouro. Essa riqueza foi essencial para saldar viagens e produtos do Oriente. ${ }^{24}$

Depois das Américas, muito dessas fontes mudaram. Especialmente a partir dos ibéricos. O metal generoso encontrado no Novo Mundo mudou a geografia, a demografia, a fisionomia, o destino das colônias e a fortuna do Brasil. Milhares de pessoas de tez branca atravessaram o Atlântico em sua procura. Milhares de índios, negros e misturados do interior foram implicados na missão. Antes e durante. Duas, três gerações de todos eles não fizeram outra coisa que viver em função dele, o metal, e para ele no caso português. A frustração do passado da colônia sem seu brilho desapareceu. A impotência diante dos cargueiros luminosos dos espanhóis chegando desde muito a portos inimigos também. Achar ouro no domínio Brasil foi a consagração da expansão. Desde Ceuta, do Marrocos, de Arguim, da Serra Leoa, da Mina, Portugal jamais disfarçara sua sede de ouro. Seu desejo de diamantes. Seu anseio por prata. Muita vez pela pura e simples necessidade. ${ }^{25}$ De 1440 a 1520 , sob bandeiras lusitanas se exploraram avidamente o golfo da Guiné. O ouro daí vinha casado com escravos e outras mercadorias de serventia. O pós-1520 foi de crise. "Secaram" as minas. Razões naturais e econômicas. A extração e o transporte ficaram excessivamente caros. Os metais da Guiné, nos barcos lusos, começaram a ter dificuldade de se pagar. As sempre implacáveis concorrências francesa, inglesa e espanhola se tornaram esmagadoras. Eram risíveis os $700 \mathrm{~kg}$ anuais de ouro português frente às mais de 4 toneladas espanholas que passaram a chegar oficialmente só no porto de Sevilha a partir de 1551, vindas em maior parte das Américas. ${ }^{26} \mathrm{E}$ que até 1783 somariam mais 45.000 toneladas de puro metal. E com o tempo fariam imortalizar a expressão vale un potosí como sinônimo de riqueza e prosperidade. ${ }^{27}$ Potosí incitava, portanto, ao Portugal um sentimento muito mais complexo que inveja. Algo próximo de ódio. Mesmo quando da união depois do desaparecimento do rei Sebastião, Alcácer Quibir.

Açúcar, tabaco, madeira, vindos das Américas com a cunha lusitana, eram afamados em todas as praças europeias. Isso já pelos fins dos quinhentos. Esses insumos, diferente do trigo, por exemplo, não sofriam de superprodução. As mesas dos países mais importantes daquele mundo mudavam numa rapidez impressionante. O gosto, inclusive do homem comum, do homem do campo, era convidado a experimentações. Pratos doces, bebidas

\footnotetext{
${ }^{24}$ Fernand BRAUDEL - La Méditerranée et le monde méditerranéen à l'époque de Philippe II. 2. Destins collectifs et mouvements d'ensemble. Paris: Armand Colin, 1990. pp. 137 ss.

${ }^{25}$ Pierre VILAR - Oro y moneda en la historia (1450-1920). 6. ed. Barcelona: Ariel, 1982. pp. 61 ss.

${ }^{26}$ Fernand BRAUDEL - La Méditerranée, op. cit., pp. 143-4.

${ }^{27}$ Niall FERGUSSON - The ascent of money. A financial history of the world. New York: Penguin Books, 2008. p. 24.
} 
quentes e frias, sobremesas se multiplicaram. Comer açúcar ia se fazendo fixação. Tara. Portugal agradecia. Holanda mais ainda. O açúcar saído do México era pouco ou nada notado. Do mesmo modo, a madeira extraída nos bálticos em nada afetava o comércio da rubra made in Brasil-Portugal. Mesmo o tabaco, primo pobre do açúcar, mercadejado pela gente de Virgínia e Maryland tinha pouca vez frente aos da Bahia e do Brasil. ${ }^{28}$

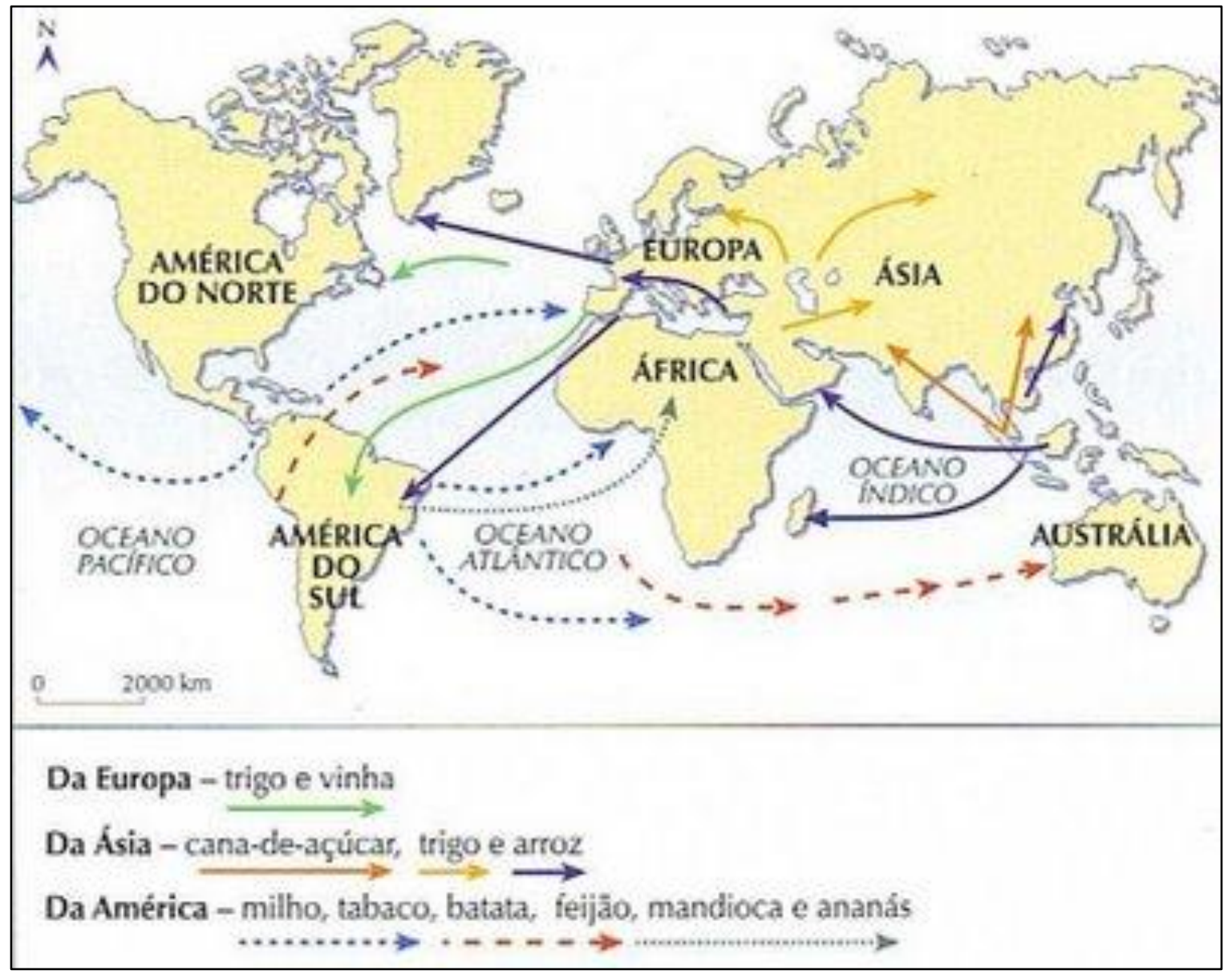

Rotas de comida pelo mundo - século XVI-XVII

Essa supremacia não perduraria. O século XVII faria estrago. Tudo que era gente consciente perderia a inocência. Centros e periferias se redefiniriam. Hegemonias se afirmariam. A economia-mundo europeia mostraria seu vigor. As estruturas do quotidiano

\footnotetext{
${ }^{28}$ Immanuel WALLERSTEIN - El moderno sistema mundial II: el mercantilismo y la consolidación de la economia-mundo europea, 1600-1750. Trad. Pilar López Máñez. Madrid: Siglo XXI de España editores, 1984. pp. 222 ss. Fernand BRAUDEL - Civilisation materiélle, économie et capitalisme - XVe-XVIIIe siècle. 1. Les structures du quotidian. Paris: Armand Colin, 1993. Caps. 2 e 3.
} 
passariam a adensar alguma sintonia. Os relógios do novo sistema mundial começariam a indicar que muito em breve, inevitavelmente, marcariam, impreterivelmente, a mesma hora. ${ }^{29}$

A depressão e a contração decorrentes da expansão do século XVI chegaram com força nos centros. Nenhum lugar europeu passou incólume. Nenhum de seus dependentes além-mar muito menos. Essa "fase b" amargou crise desconcertante. Crise total. Economia, política, religião, artes. Tudo foi rasteirado. Impactado. Modificado. Houve a revolta e a revolução dos preços. O radical do fenômeno foi o seu destino: a barriga. O preço dos cereais perdeu o juízo. Caros para se comprar. Baratos demais para se vender. Sobe e desce rápido e sem razão nem moderação. Tudo parte decorrente e em decorrência do ouro e da prata que rápida e com razão minguaram nos portos metropolitanos. Induzindo seu preço às alturas. Prata caríssima. Ouro, mais ainda. Diminuição consequente e inevitável do meio circulante. Menos moeda no mercado. Deflação monetária. ${ }^{30}$

Esse contexto horripilante pôs em questão a centralidade de Amsterdam. De 1651 a 1689, Paris e Londres não fizeram outra coisa que impulsionar direta e ostensivamente o desaparecimento de seu rival holandês. Constrangidos em Europa e combatidos no Brasil, esses holandeses se estabeleceram nas Antilhas; Barbados, Curaçao. Objetivo: continuar potência. Maneira: fazendo açúcar. O impacto sobre os desafetos foi imediato. Portugal sentiu. A Inglaterra, que se punha insone a auxiliar os portugueses a esquecer dos tempos que respondiam ao rei Felipe, reagiu. Foi por 1670, no âmbito de crise nos centros e crise nas periferias, que Londres conseguiu reavivar, ou ao menos avivar com força, o apetite de ouro nos portugueses dos dois lados dos mares. ${ }^{31}$ Os paulistas, havia tempo empenhados em entrar e desbravar grotões, foram executores naturais da empresa. Uns brancos, alguns negros,

\footnotetext{
${ }^{29}$ A discussão sobre esse processo, a transição, é especialmente sensível. Para além das proposições de Immnuel Wallerstein, que venho admitindo aqui, vale incorporar, ou ao menos mencionar, o tenso debate Maurice DOBB - A evolução do capitalismo. Trad. Manuel do Rêgo Braga. 7. ed. Rio de Janeiro: Zahar Editores, 1980 e Paul M. SWEEZY - Teoria do desenvolvimento capitalista. Princípios de economia política marxista. Trad. Waltensir Dutra. 2. ed. Rio de Janeiro: Zahar Editores, 1967. De modo mais específico e ainda mais tenso, os artigos contidos em T. H. ASTON \& C. H. E. PHILPIN (Org.) - El debate Brenner: estructura de clases agraria y desarrollo econômico en la Europa preindustrial. Trad. Isabel Moll y Paulino Irdiel. Barcelona: Editorial Crítica, 1988. As implicações da manifestação desse processo de transição nas ibero-Américas podem ser bem capitadas em Antonio Carlos Robert MORAES - Bases da formação territorial do Brasil. O território colonial brasileiro no "longo" século XVI. São Paulo: Hucitec, 2000.

${ }^{30}$ Immanuel WALLERSTEIN - El moderno sistema mundial II, op. cit., pp. 5-6, pp. 17-46. Pierre VILAR - Oro y moneda en la historia (1450-1920), op. cit., pp. 50, 259 ss. Vitorino Magalhães GODINHO - Prix et monnaies au Portugal. Paris: Armand Colin, 1955. Frédéric MAURO - Nova história e novo mundo. 3. ed. São Paulo: Perspectiva, 1973. pp. 107-33.

${ }^{31}$ Pierre VILAR - Oro y moneda en la historia (1450-1920), op. cit., pp. 320 ss. Immanuel WALLERSTEIN El moderno sistema mundial II, op. cit., pp. 223, 341 ss.
} 
centenas de mamelucos e milhares de índios seguiram os sinais do metal até achar. ${ }^{32}$ Enquanto isso, embarcações inglesas, e francesas, seguiam dando batida nos portos das Américas em sua sina de contrabandos e, portanto, sendo o que sempre souberam ser: bandidos. Para, quem sabe, moralizar e, certamente, facilitar esse assalto, esses ingleses fiaram a criação da colônia de Sacramento. ${ }^{33}$

Nos fins dos seiscentos, depois de assassinarem muita gente, inclusive o nobre espanhol Rodrigo de Castelo Branco, os paulistas encontraram o ouro. Por 1699, 725 quilos foram enviados para Portugal. Em 1701, 1.785. 1704, 9.000. 1712, 14.500. 1720, 25.000. $1725,20.000$.

Esses números, de surpreender mesmo os olhares atentos e experimentados da gente de Sevilha, representavam fração muito pequena do montante extraído. A maior parte chegava aos portos ingleses por contrabando. ${ }^{34}$ Esse contrabando auxiliou, e em muito, no desbanque dos holandeses. Ainda nos últimos instantes do século XVII, a gente de Londres fundou o Banco da Inglaterra. Seu objetivo era diverso. Restabelecer a ordem monetária do espaço europeu fundamentalmente. Xeque-matear os bancos municipais de Amsterdam, Barcelona e Rialto essencialmente. Massacrar os banqueiros e manipuladores privados concretamente. Foram duríssimos os ajustes monetários do triênio 1694-1696. O destino iria forjar os portugueses a assinar as diretrizes do sir Methuem em 1703. O mesmo destino deixaria ainda mais robusta a aliança anglo-lusitana no acerto de contas da guerra de sucessão espanhola. Harmonia diplomática; harmonia militar. Aos homens de Lisboa não restava que fazer vista grossa ao assalto ao ouro saído do Brasil. ${ }^{35}$

O ouro que restou gerou complicações em Portugal e no Brasil. Novamente dificuldade com preços. Autonomia monetária foi um antídoto. Também por isso se fundou a casa da moeda na Bahia em 1694 e no Rio de Janeiro em 1702.

\footnotetext{
${ }^{32}$ Laura de MELLO E SOUSA - O sol e a sombra: política e administração na América portuguesa do século XVIII. São Paulo: Companhia das Letras, 2006. pp. 81 ss. Charles Ralph BOXER - The Golden Age of Brazil, 1695-1750. Berkeley: University of California Press, 1964. João António ANDREONI - Cultura e opulência do Brasil. São Paulo: Companhia Editora Nacional, 1967.

${ }^{33}$ Pierre VILAR - Oro y moneda en la historia (1450-1920), op. cit., pp. 320 ss. Immanuel WALLERSTEIN El moderno sistema mundial II, op. cit., pp. 223, 341 ss.

${ }^{34}$ Immanuel WALLERSTEIN - El moderno sistema mundial II, op. cit., p. 231.

${ }^{35}$ Pierre VILAR - Oro y moneda en la historia (1450-1920), op. cit., pp. 299-321.
} 


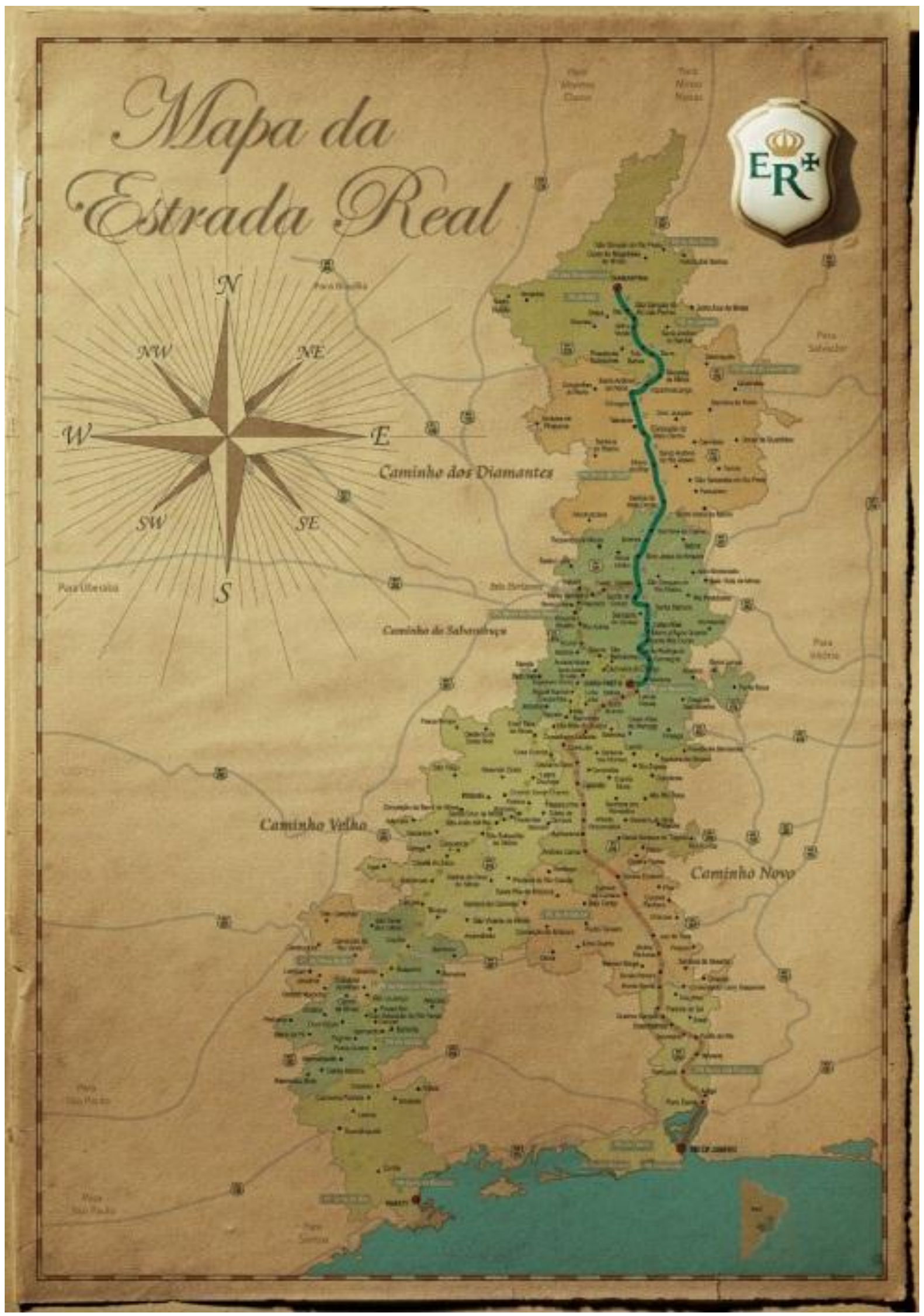


Esses eventos de aguda depressão coincidiram com a consolidação da aprendizagem da colonização. Escravização de negros e outras práticas de trabalho compulsório não garantiriam a exploração plena dos espaços conquistados. Os europeus colonizadores estavam cientes. Não demorou a ficarem convencidos. Ao longo do século de expansão, 1450-1550, essa foi a lição da experiência. Nos anos de 1530, a ostensiva ofensiva francesa e o esfriamento dos negócios no Oriente forjaram a valorização do domínio americano português. Os sistemas de feitorias e capitanias hereditárias até então implantados se revelaram fracassados. Ou, no mínimo, improducentes. A estratégia foi apostar na centralização da administração com a criação do governo geral. ${ }^{36}$ Em 1549, Tomé de Souza se instalou na São Salvador da Bahia de Todos os Santos. O nome que colou na cidade, cidade da Bahia, expressava, antes e acima de tudo, a oportuna condição de sua localização. ${ }^{37}$ Essa nova direção não demorou a redefinir o lugar da colônia na metrópole. Sua vocação de produtora de açúcar foi se desenhando ao passo que o produto foi ganhando importância no mercado internacional. Nisso, a economia de coleta, que impunha o emprego de índios no corte de paubrasil, foi dando lugar à economia de produção, estruturada definitivamente em torno de engenhos de açúcar tocados por escravos africanos. Nos fins dos quinhentos, o negócio estava praticamente encaminhado. Os colonos recorriam à metrópole para vender seus produtos e comprar seus meios de produção. Lisboa se afirmava núcleo ativo do sistema. Recebia mercadorias do domínio e intermediava o tráfico de escravos para os domínios. Essa triangulação definiu a presença e o poder luso no Atlântico sul. Diferente das mercadorias vindas dos domínios - mandioca brasileira, tecidos asiáticos, metais preciosos africanos - que eram redistribuídas desde os portos portugueses, o escravo, mercadoria viva, ia direto ao seu destino. Essa característica foi marcando não apenas a economia, mas a política, a demografia e a fisionomia dos territórios implicados. O aumento progressivo da importância do açúcar imputava razão proporcional à necessidade de produção e de meios de produção. Aos meados dos seiscentos, a utilização de braços negros na composição do sistema se tornou irreversível. Essa condição revelaria a desterritorialização do mercado de trabalho colonial. A força de produção, o escravo, vinha de fora de Portugal e de fora da colônia.

\footnotetext{
${ }^{36}$ Luiz Felipe de ALENCASTRO - O trato dos viventes. A formação do Brasil no Atlântico sul. São Paulo: Companhia das Letras, 2000. pp. 11-2.

${ }^{37}$ Milton SANTOS - O centro da cidade de Salvador. São Paulo: Edusp, 2008. p. 39.
} 


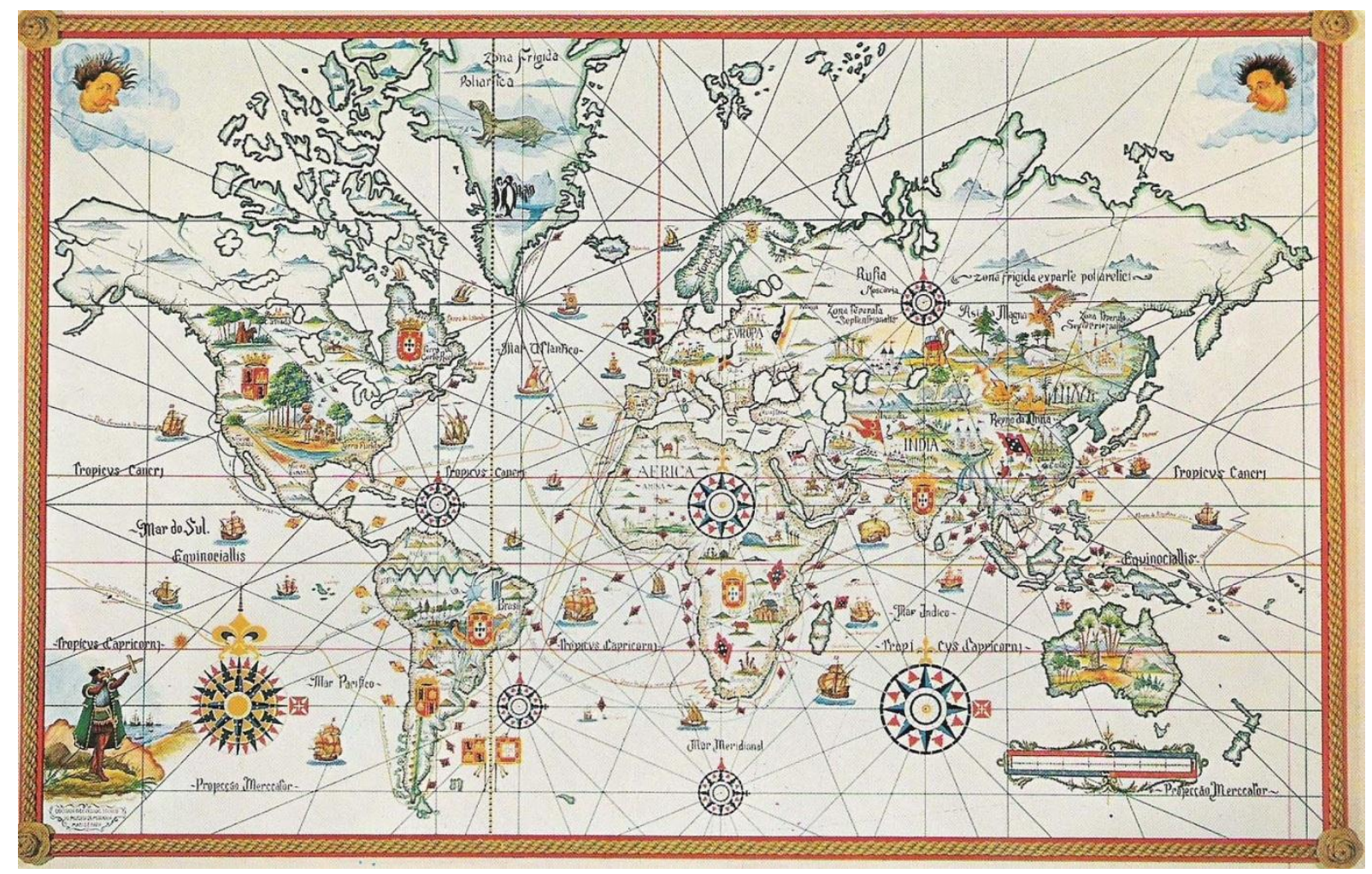

Descobrimentos

O contraponto luso-americano foi especialmente Angola. Mais e mais navios saíam dos portos de Recife, Rio de Janeiro e Bahia sentido Luanda. Menos e menos navios saídos de Portugal aportavam na capital angolana. A bilateralidade no Atlântico sul se fazia regra. $\mathrm{O}$ recintamento dos continentes conduzia o redesenho imaginário do mundo pangéico de antanho. Mandioca, milho, batata-doce, frutas americanas, cachaça, fumo ingressaram e/ou se desenvolveram rapidamente na dieta da gente de Angola. Toneladas desses produtos foram comerciadas ou enviadas de costas brasileiras para costas africanas. Fumo e cachaça viraram importante moeda de troca. Escambo. Muitos escravos foram trocados por fumo e cachaça. ${ }^{38}$ Quando o ouro foi encontrado, a estrutura da economia colonial estava totalmente costurada. O brilhante metal seria apêndice. Importante. Mas apêndice.

Apêndice, mas importante. Antes dele, o fundamento do meio circulante da colônia vinha do Peru. De Potosí com escala em Buenos Aires. Quando da união ibérica, a gente do Rio de Janeiro abdicou da caça de índios para privilegiar a construção naval, o comércio de escravos e as trocas na região do Prata. O nome desse intercâmbio foi Salvador Correia de Sá

\footnotetext{
${ }^{38}$ Luiz Felipe de ALENCASTRO - O trato dos viventes, op. cit., pp. 11-2, 20, 27-9, 40-1, 251-4, 324-5.
} 
Benevides. Filho de mãe espanhola e pai fluminense, Salvador de Sá, casado com Caetana de Velasco, viúva do ex-governador do Paraguai e Tucumã Juan de Velesco, aumentou significativamente o cabedal de bens e influência dos Sá em todo o mundo platino. Tendo dispensado mais de seis anos morando na região, Salvador de Sá foi várias vezes às minas de Potosí e consolidou seu fascínio e domínio do negócio da prata. Tornado governador do Rio de Janeiro em 1637, após gestões do pai e de avôs, trabalhou diuturnamente para manter livre o canal de acesso à prata peruana. Depois da restauração, não era outro o desejo de Lisboa. Mesmo sendo a mesma Lisboa receosa de o nobre governador trocar de coroa, vestir bandeira espanhola, por conta do forte poder de sedução de Buenos Aires e adjacências. Decorrência do receio e estratégia para agregar ou ao menos manter proximidade descomprometida com a região do prata, Portugal mandou povoar Laguna em 1674 e criar, dois anos depois, o bispado do Rio de Janeiro com jurisdição até o Prata. A fundação de Sacramento veio na sequência. Em 1680. ${ }^{39}$ Bem ou mal, enquanto o rei Felipe da Espanha dava as cartas ao Portugal e aos governadores Martin de Sá depois Salvador de Sá no rio da Prata, não faltou moeda nas praças da colônia. A partir da metade dos seiscentos, a falta de dinheiro gerou ruína, carestia, miséria. Nos últimos anos dos terceiro e quarto quartos daquele século, a desgraceira tomou conta da Bahia. O relatório do governador Antônio Luiz Gonçalves da Câmara Coutinho informava ao rei português de modo terminal que "a miséria e a penúria" eram a regra em todo o estado do Brasil. Não havia mais moedas. Inexistia dinheiro. ${ }^{40}$ Não tinha dinheiro, especialmente, porque faltava o insumo para produzi-lo. Minguara a prata. Essa situação abriu vazão para se malversar. Produzir moeda falsa virou açúcar em bolo doce. Pão pras horas de precisão. Grupos de falsários se multiplicaram pela Bahia. Sua função não era outra que adulterar moedas de prata e ouro. Raspando seus bordos, apagando seu valor facial, fundindo as aparas acumuladas, comprando e vendendo metal. Em 1693, um observador da câmara notou que quando eram comuns dois ou três navios de prata e ouro vindos de Buenos Aires entrar no porto da Bahia, havia apenas um ourives na cidade. Francisco Vieira, o Fanha. Que bem trabalhava com o suporte de não mais que seis ajudantes. E dava conta de todas as demandas. Com o fim dos carregamentos, só São Salvador tinha uns 25 ourives prontos para todo tipo de negócio. Sujo. ${ }^{41}$

\footnotetext{
${ }^{39}$ Charles BOXER - Salvador de Sá and the struggle for Brazil and Angola, 1602-1686. London: Greenwood Press, 1975. Cap. 1. Luiz Felipe de ALENCASTRO - O trato dos viventes, op. cit., pp. 199-203.

${ }^{40}$ Relatório de Antônio Luiz Gonçalves da Câmara Coutinho, governador da Bahia. 4 de julho de 1692. In.: Inês INÁCIO \& Tania Regina DE LUCA - Documentos do Brasil Colonial. São Paulo: Ática, 1993. pp. 112-5.

${ }^{41}$ João Adolfo HANSEN - A Sátira e o Engenho. Gregório de Matos e a Bahia do século XVII. 2. ed. rev. São Paulo: Ateliê Editorial, 2004. pp. 160-5.
} 
Viver de ouro era perigoso. Sem ele, pior. O passar dos anos ia mostrando. A renda média dos demais produtos, açúcar em especial, era mais equilibrada. O ouro, para Portugal, era fictício. Somente simulava riqueza. O benefício foi majoritariamente para outros. Geralmente para os ingleses. Com o ouro das minas, eles, especialmente os ingleses, estabilizaram seu sistema bancário, estimularam sua produção de manufaturas, ampliaram sua capacidade de importação, trouxeram o centro financeiro de Amsterdam para Londres. ${ }^{42}$ Tudo isso ambientou o segundo momento de "luta no centro". 1689 a 1763 viu alguma quase nenhuma crise econômica e muita violência militar e diplomática. Os dois grandes do pedaço, França e Inglaterra, promoveram guerras sem fim. O mundo ficou pequeno para eles. A Europa e as Américas essencialmente. ${ }^{43}$ A visita do nobre sequestrador René Duguay-Trouin ao Rio de Janeiro em 1711 foi apenas uma mostra disso. Amigos de inimigos eram inimigos. Portugal e Brasil foram seguidamente visados por estarem do lado de Londres. Espanha e seus domínios, por estarem do lado de Versailles. Agressão e intimidação foram recorrentes. Mesmo entre os siameses Portugal e Espanha. A história e a geografia já os haviam condenado a ser vizinhos. Na Europa e fora dela. Nada sugeria que mudariam de endereço. Num lugar ou noutro. Sendo assim, tinham duas alternativas imediatas. Engolir a mágoa e contemporizar as diferenças ou remoer suas histórias e vingar tanta humilhação. O plano b venceu. Manter Sacramento parte de Portugal seguiu sendo, antes de tudo, uma questão de honra. Dificultar a vida dos homens del Prado, uma missão. Isso queria dizer que a guerra dos outros, a luta no centro, era suposto para essa luta particular, na periferia e na semiperiferia.

Ouro e Sacramento se melaram nessa confusão. Durante 60 anos, antes do achamento e ao longo da exploração do ouro (e dos diamantes) no Brasil, 600 mil pessoas atravessaram o Atlântico na busca de um mundo melhor. Quase todos voluntariamente. Sempre na miragem do metal. Sem grilhões nem amarras. Muitos sem dinheiro nem comida. Só com a coragem. Que logo se mudaria em destino. O contingente de gente livre aumentou agressivamente nas terras luso-americanas. Ao menos o silêncio e a solidão dos primeiros anos da colonização ${ }^{44}$ foram, ao certo, desaparecendo. Em toda a serra da Mantiqueira e em todo o Cuiabá, cidades e

\footnotetext{
${ }^{42}$ Celso FURTADO - Formação econômica do Brasil. 27. ed. São Paulo: Publifolha, 2000. pp. 29-31, 83 ss.

${ }^{43}$ Immanuel WALLERSTEIN - El moderno sistema mundial II, op. cit, pp. $341 \mathrm{ss.}$

${ }^{44}$ Fernando A. NOVAIS - Condições de privacidade na colônia. In.: Laura de MELLO E SOUZA - História da Vida Privada: o cotidiano e a vida privada na América portuguesa. São Paulo: Companhia das Letras, 1997.
} 
cidadezinhas e vilas e lugarejos foram se formando velozmente. Certo que populações inteiras, por vez, surgiam e desapareciam do dia para a noite. Muita vez mesmo antes de chegar, começar, a noite. Mas isso era desimportante. Fundamental era que pela primeira vez o uti possidetis estava sendo aplicado de verdade. Os momentos mais que sofridos vividos em Portugal e na Europa nos tempos de recessão traumatizaram toda uma civilização. Os homens e mulheres de bem e da vida que, agora, conseguiam chegam a terras americanas, começaram a cogitar não voltar. Com algum quê de losers, viam no ouro e nas minas o fim da partida. Em Portugal, seu passado. A maldição. Como Sodoma e Gomorra dos tempos de Ló. Nada mais justo. Afinal, "todo indivíduo que pertence a uma determinada massa leva dentro de si um pequeno traidor que quer comer, beber, amar e ser deixado em paz". 45 De toda maneira, por ou contra, o empenho dessa gente fez aumentar a importância estratégica da capitania do Rio de Janeiro. Muitos deles chegavam por ali. Muito do que produziam - o ouro - saía por ali. Nesse sentido, tem muita razão Niall Fergusson quando, emulando Balzac, constata que "behind each great historical phenomenon there lies a financial secret". ${ }^{46} \mathrm{O}$ segredo financeiro dali esteve inegavelmente ancorado no ouro. O que não necessariamente impulsionou a mudança da capital para o Rio de Janeiro. Justamente porque talvez essa mudança não tenha representado em nada extraordinário grande fenômeno histórico.

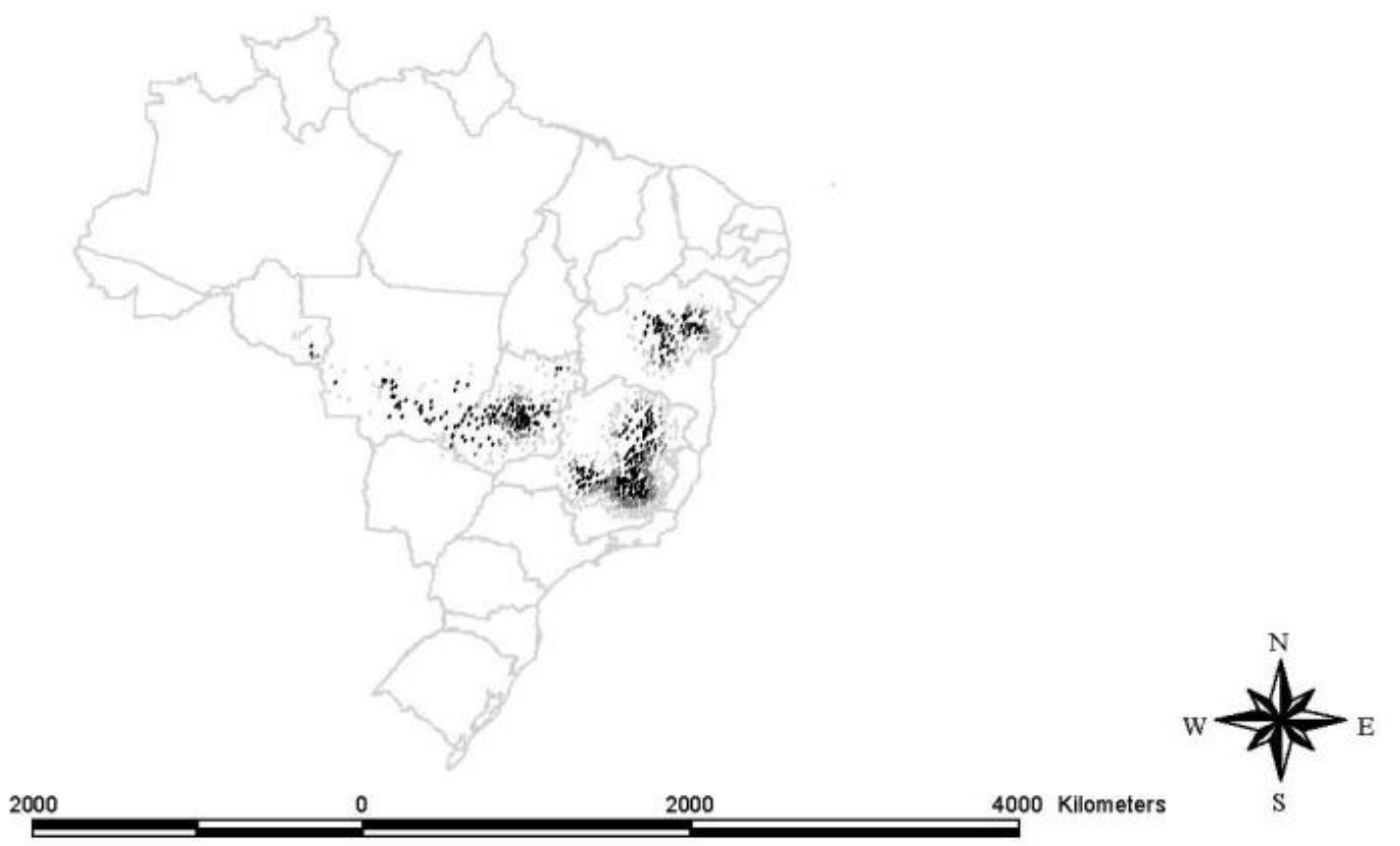

Espacialização da exploração de ouro ${ }^{47}$

\footnotetext{
${ }^{45}$ Elias CANNETTI - Massa e Poder. Trad. Rodolfo Krestan. Brasília: Editora UnB, 1983. p. 21.

${ }^{46}$ Niall FERGUSSON - The ascent of money, op. cit., p. 4.

${ }^{47}$ Joana NARITOMI - Herança colonial, instituições \& desenvolvimento. Um estudo sobre a desigualdade entre os municípios brasileiros. Rio de Janeiro, 2007. (Dissertação apresentada ao departamento de Economia da PUC-RIO), p. 87.
} 
Malgrado os sabidos fluxos e refluxos do envio anual do metal ao reino, a partir de 1750 foi evidenciada uma tendência a crise estrutural na extração do produto. Ainda nesse decênio dos cinquentas, as 100 arrobas de quota foram satisfeitas. No seguinte, não mais. 86 arrobas foram médias, desconsiderando a margem de erro que, se levada a sério, sempre jogaria para cima, dado aos desvios. Os secretários do rei José estavam por dentro. ${ }^{48}$ Mais que isso. Sabiam que não se executa mudança a longo termo com base em situação casual. Metais preciosos, estavam persuadidos, tinham vida curta. Não eram eternos. O metalismo não poderia ser forma de governo. Embora tenha sido. Era antes infortúnio. O exemplo espanhol servia de exemplo. ${ }^{49}$ Ao que consta, jamais se insinuou fazer de Potosí capital. Essa convicção dos portugueses, e ingleses, pode sugerir diminuição importante na possível "capitalidade" do Rio de Janeiro. Restava ao contencioso Sacramento o impulso.

O desaparecimento do rei João coincidiu com os momentos iniciais de execução do tratado de Madrid de 1750. A ascensão do rei José e do secretário Sebastião matizou a empresa. O núcleo não era bem só Sacramento. E sim a readequação dos limites das Américas de Portugal e Espanha depois das Tordesilhas. Mas Sacramento acabou ganhando dimensão. Não tinha como não. Muita honra. Muito metal. Muito comércio. Muito escravo. Das primeiras decisões do rei e do secretário foi mandar nominar alguém para coordenar e vistoriar a demarcação. O governador Gomes Freire de Andrade, o conde de Bobadela ${ }^{50}$, foi o indicado. O secretário Sebastião tinha inteira confiança nele. Eram próximos e prósperos. Aos funcionários do conselho ultramarino ficou a incumbência, que lhes era concernente, de assessorar o nobre governador. Seu ofício no extremo sul não era dos mais excitantes. Lisboa e Madrid e Paris e Londres sabiam. A possibilidade de dar em nada era muito grande. O pessimismo era explícito. E desde os primeiros minutos. Quase ninguém o dissimulou. O cálculo era preciso. O arrastar dos anos só fez confirmar. E, mais que isso, amplificar a preocupação dos altos funcionários do rei José para suas próprias casas. Portugal e Europa. Eram os anos de 1750. Neles aumentou o acirramento definitivo da luta no centro. Precisou chegar 1762-3 para a Inglaterra impor seu sucesso.

\footnotetext{
${ }^{48}$ Kenneth MAXWELL - A devassa da devassa, op. cit., p. 65.

${ }^{49}$ Pierre VILAR - Oro y moneda en la historia (1450-1920), op. cit., pp. 213 ss.

50 Ao longo do estudo, utilizarei mais frequentemente Bobadela que governador Gomes Freire de Andrade. Diferente da escolha para me referir ao marquês de Pombal. Embora mencione Bobadela para momentos em que o governador do Rio de Janeiro ainda não tinha o título, e isso é, indubitavelmente, pecaminosamente anacrônico, o faço por ao menos uma razão. Quando de sua morte em 1763, que é onde fixo a tônica de sua participação na história que vou contando, ele já possuía o título.
} 
1762-1763 foi um ano, ano e meio daqueles. Disso ninguém duvida. A paz de Paris serenou as animosidades no espaço europeu. O rei Louis XV pôde novamente enviar embaixadores para Lisboa. O rei Carlos, para Londres. E ao contrário. Moscou, Viena, Amsterdam, Nápoles, e outros, que jamais foram amigos, menos ainda em espaços portugueses, passaram a se tratar com alguma educação. Mesmo que ríspida e seca e longe de ser voluntariamente afável. A paz saída de Paris era aparente. Seus efeitos colaterais foram se mostrando imensos. O povo, que ia pagando centavo por centavo das guerras precedentes, não ficou nada entusiasmado. ${ }^{51}$ Não tinha nada menos popular que fazer guerra. Com o reino do rei José não foi diferente. Por ao menos dois terços da guerra que findou efetivamente no 10 de fevereiro de 1763, Portugal esteve plenamente envolvido. Durante, ao menos três dos sete anos de conflito, Portugal não fez outra coisa senão viver intensamente a guerra. Do 27 de dezembro de 1761 ao 13, 15 de setembro de 1762, o gabinete do secretário Sebastião passou em claro, ancorado em pesadelo de noite sem fim. Como aliado de primeira hora do rei George do Reino Unido e inimigo de todos os momentos de toda a gente del Prado, os homens de Lisboa foram absorvidos pelas circunstâncias. O reino ficou cercado. Sem potência. Sem poder. Edward Hay, enviado do rei George na corte lusa, fez de Lisboa um posto avançado do Westminster. O todo poderoso secretário Sebastião teve de se conformar. O rei José não fazia nenhuma questão. Realmente somente os sábios conseguem identificar o melhor momento de recuar. O rei português não era estulto. Estava longe de ser impermeável. Era ungido, mas racional. Perfeitamente passível de ser persuadido. Gostava, pelo que contam, muito de ópera e caça. Mas era muito mais que somente caçador e auditor. Seu embaixador em Londres só fez reforçar a gravidade global da situação com o apoio dos aliados ingleses e sua tragicidade sem. Depois do sismo de 1755, quase nada foi decidido nas secretarias do rei José sem o consentimento ou mínimo conhecimento de Londres. Depois do estúpido assalto de Lagos, quando a British navy destruiu navios com bandeira de Versailles em solo luso dito neutro, praticamente tudo de importância foi decidido com aval da corte do rei George. Diante dessa intensa colaboração, parceria ou - se se quiser - intervenção, nada mais natural que estudar mais detidamente essa relação.

\footnotetext{
${ }^{51}$ Paul KENNEDY - The Rise and Fall of the Great Powers. Economic Change and Military Conflict from 1500 to 2000. New York: Random House, 1987. pp. 147 ss. Jeremy BLACK - Eighteenth century Europe. 17001789. London: The Macmillan Press, 1990. pp. 276 ss.
} 
Quem primeiro parece ter querido desafrancesar - no sentido analítico e documental a abordagem e a compreensão do período foi, por certo, Dauril Alden. Diplomacy and war, capítulo 4 de seu monumental e ainda importante Royal government in colonial Brazil, indica fundamentos para compreensão da importância e da complexidade da internacionalidade dos fenômenos. No caso, sua obsessão era o contencioso Sacramento. E aí, com outro foco e outro recorte, as minúcias da atuação dos enviados ingleses em Lisboa ficaram em outro plano. ${ }^{52}$ Pombal and the Nationalization of the Luso-Brazilian Economy de Kenneth Maxwell colocou em relevo a importância da Inglaterra nas coisas do Portugal. A indisposição dos secretários do rei José com industriais ingleses pôs em evidência a dimensão da relação luso-inglesa e seu peso no equilíbrio europeu. ${ }^{53}$ Mas foi n'A devassa da devassa que o que era sugestão virou argumento. Leitura atenta do capítulo Mudança, segundo do livro de Maxwell, mostra isso. Embora todos os movimentos do estudo tenham como matriz a relação anglo-portuguesa. ${ }^{54}$

Evidenciar essa relação Londres-Lisboa-Londres significaria nada dizer. Maxwell, principalmente, e outros, tudo já disseram. Diferente é levar em conta e às últimas consequências concretas que ela, a relação anglo-portuguesa, obviamente, teve no quotidiano do exercício do poder em Lisboa. Especialmente durante os primeiros treze anos da administração do rei José e do secretário Sebastião. 1750-1763.

Tem muita razão Antonio Manuel Hespanha ao observar que 1750 era como "o princípio do fim". 55 Sim. Foi um rasgo na história das gentes do Portugal. Fossem do continente, fossem d'além-mar. Mas tendo a sugerir que, para o caso de Portugal e Brasil, esse crepúsculo ocorreu no bloco fechado dos anos de 1750 a 1763. Nesse período, reino e domínio ficaram imersos na indefinição. O horror tomou, sim, conta do Rio de Janeiro, como bem disse Maria Fernanda. ${ }^{56}$ Mas carcomeu todo o resto do território em igual ou maior proporção. Não era nada fácil estar nos extremos. Espanhóis não fizeram outra coisa que molestar quem vivia nas bandas do sul. Muita vez, a ferro. Toda vez, a fogo. Não foram menos incomodados os brasílicos que viviam na Amazônia e no Grão-Pará. Franceses, e espanhóis, fizeram hobby e job intimidar esses locais. Qualquer franco-invasor da parte do rei

\footnotetext{
${ }^{52}$ Dauril ALDEN - Royal government in colonial Brazil: with special reference to the administration of the Marquis of Lavradio, viceroy, 1769-1779. Berkeley: University of California Press, 1968.

${ }^{53}$ Kenneth MAXWELL - Pombal and the Nationalization of the Luso-Brazilian Economy. The Hispanic American Historical Review, vol. 48, n. 4, pp. 608-631, nov. 1968.

${ }^{54}$ Kenneth MAXWELL - A devassa da devassa, op. cit.

55 Antonio Manuel HESPANHA - $O$ antigo regime. Lisboa: Estampa, 1998. p. 10.

${ }^{56}$ Maria Fernanda BICALHO - A cidade e o império, op. cit., pp. 60 ss.
} 
Louis sonhava com Recife sem desprezar São Salvador. A impiedade do sismo de 1755 forçou unidade solidária para reconstruir Lisboa. Nenhuma indulgência brilhava nos olhos e nas ações dos enviados espanhóis e franceses que estavam, em solo português, prontos para pôr facas no pescoço de todos os secretários do rei José e inclusive no do rei José no momento mais agudo da guerra anos depois. Queira ou não se queira, o cetro do rei George impediu que a desgraceira não fosse maior do lado de lá e de cá. Em Portugal e no Brasil. E foi, naturalmente, somente depois de 1763 que os homens de Lisboa conseguiram melhor respirar sendo que os senhores de Westminster se viram consumidíssimos com as demandas da sua gente no ultramar.

Fundado nessa convicção e sem perder de vista os demais membros do concerto europeu, analisei praticamente todos os cables Londres-Lisboa-Londres e Londres-LisboaBrasil-Lisboa-Londres-Lisboa disponíveis para o período 1750-1763. Não se trata, pura e simplesmente, duma história diplomática. Muito menos tão somente duma história da diplomacia anglo-luso-brasileira. O núcleo da perquirição, que ensaia plasmar ambos os recortes diplomáticos, induz à explicitação dos supostos mais decisivos da conjuntura daquele momento que colaboraram para a tomada de decisão do rei José e do secretário Sebastião de mudar o lugar da sede do vice-reinado no Brasil. A relação entre Lisboa e Londres não era pueril. Desconsiderar a intensidade dessa relação, não apenas empobrece como deforma qualquer abordagem acerca da administração do destino daquele Brasil. Esse modo de valorização tende a suscitar contrapontos duros. Dito no popular: oposições destruidoras. Geralmente com razões. Geralmente com más-fés. Quase sempre ideológicas. Ancoradas em convicções desprovidas de evidências ou, no canteiro da história, exangues em evidências. Até melhor juízo, não representa ingenuidade alguma lançar mão de expediente diplomático para compreender o processo de tomada de decisão em Portugal e algures naqueles anos. Não representa, até comprovação contumaz, oportunismo algum nem facilidade adicional e descompromissada privilegiar a esfera do poder na gestão da administração das coisas do reino. O rei José e o secretário Sebastião, ao seu tempo e maneira, eram encarregados de sustentar a responsabilidade de adotar decisões. Nem sempre as corretas. Nem sempre as melhores. Quase nunca as mais populares. Sempre provocando imensa decepção. Frustração no plural. Nem o rei José, nem o secretário Sebastião, nem qualquer alto funcionário do reino, se dedicava a comentar os acontecimentos. Não era sua função. No torvelinho dos dias de guerra e de paz, seus comentários em si eram decisão. Parece elementar redizer e é 
constrangedor tentar esclarecer, mas era, como sempre foi e será, absolutamente diferente a responsabilidade de tomar decisão da de comentar decisão tomada ou a tomar. Por mais que o ambiente das duas práticas fosse quase que completamente fechado, o risco de uma prática e de outra tinham pesos e medidas extremamente diferentes. Reconstituir a história política desse período vira incontornavelmente reconstruir esse ambiente. Isso envolve ampla humildade e profunda honestidade ${ }^{57}$ Certos ou errados, o soberano luso e seus funcionários adotavam medidas sob o controle de densos e complicados planos estratégicos cosidos no tempo. Toda atuação seguia cálculos técnicos e ideológicos muito próprios. Merece respeito um alto funcionário em ação. Merecem respeito críticos com convicção. O "princípio do fim" que viviam era momento de crise. Não se faz outra coisa em tempo de crise que tomar decisão. Os vestígios e a inteligência nem sempre possibilitam a compreensão balanceada de todos os supostos das decisões. ${ }^{58}$ Sem humildade não há reconstituição. A decisão de mudar o vice-reinado para o Rio de Janeiro não causou alvoroço nem discussão. Com razão. Esse silêncio é, no fundo, o que vai problematizado e esboçado no tudo a seguir.

$\mathrm{Na}$ travessia dessa selva selvagem sem Virgílio nem Beatriz, muita vez sem encanto nem salvação, que é escrever sobre história num mundo onde poucos são humildes e honestos e pouco covardes e afetados o bastante para aceitar diferenças e convicções, foi impossível não perder em leveza. Tinha razão o poeta quando aforismava que "ninguém passa impune sob palmeiras”. Graças a diversas pessoas, próximas, amigas, indulgentes, sinceras ou respeitosas, não perdi de todo o prumo nem o rumo. André Rodrigues Nagy, Antonio Carlos Robert Moraes, Bernardo Sayão, Daniel Oliveira, Raul Mateos Castell, Rosemberg Ferracini e Wilson do Nascimento Barbosa sabem exatamente o impasse onde tudo começou. Maria Inez Machado Borges Pinto orientou com interesse e afeição e obstinação e carinho todos os movimentos do trabalho. Luiz Felipe de Alencastro dirigiu o estudo no Centre d'Etudes du Brésil et de l'Atlantique Sud da Université de Paris IV - Panthéon-Sorbonne. Lluis Ferran Toledano Gonzáles, no Departament d'Història Moderna i Contemporània da Universitat Autònoma de Barcelona. Francisco Morente Valero desburocratizou minha ida à Espanha.

\footnotetext{
${ }^{57}$ Como assevera Richard Sennett, "Chega-se à honestidade intelectual precisamente admitindo-se a realidade da contradição e abstendo-se de qualquer esperança de chegar a uma afirmação imutável". Richard SENNETT O declínio do homem público: as tiranias da intimidade. Trad. Lygia Araujo Watanabe. São Paulo: Companhia das Letras, 1988. p. 63.

${ }^{58}$ Carlo GIZNBURG - O fio e os rastros: verdadeiro, falso, fictício. Trad. Rosa Freire d'Aguiar e Eduardo Brandão. São Paulo: Companhia das Letras, 2007. Roger CHARTIER - Inscrire et effacer. Culture écrite et littérature (XIe-XVIIIe siècle). Paris : Gallimard, 2005.
} 
João Roberto Patrinhani, minha ida para a França. Nelson Caetano, para toda parte e muitas coisas. Adone Agnolin e Henrique Antonio Ré e Júlio Couto Filho, como também Antonio Carlos e Wilson Barbosa, leram o projeto inicial e/ou diversas versões carunchadas do texto. Paulo Roberto de Almeida, entre Brasília e Paris, e Antonio Risério, entre Brasília e Salvador, foram prestativos em momentos decisivos. Nelson Nozoe, esse exímio economista historiador economista, examinou com extraordinário cuidado e respeito e apreço o prólogo Pés de barro. O embaixador Alberto da Costa e Silva muito generosamente me colocou em contato com o embaixador Rubens Ricupero. Josep Fontana i Lázaro, autor do monumento Por el bien del imperio: una historia del mundo desde 1945 (Barcelona: Passado \& Presente, 2011), comentou paciente e afavelmente algumas das ideias da tese em seu despacho na Universidad Pompeu Fabra. José Luiz-Ruiz Peiñado Alonso foi absolutamente torena comigo na Universidad de Barcelona. Roger Chartier me recebeu com simpatia no Collège de France. Diversas pessoas, na London school of economics and political science. Frank Débie e Pascal Fontaine, na École Normale Supérieure. Michel Foucher, em seu Grand séminaire de géopolitique. Antoni Moliner, Borja de Riquer, Ferran Archilés, Lluis Roura, Jesus Millán, María Cruz Romeo, Martin Ramos, Pere Gabriel e Ramón del Río ampliaram minha compreensão da história das Espanhas. Agnes Mariano, Anete Ivo, Graça Cantalino, Maria de Azevedo Brandão, Firmo David Azevedo, Paulo de Jesus e Ricardo Wildberger, das Bahias. Felipe Andrade Abreu e Lima, das arquiteturas coloniais. Lívia Carvalho Pedro, essa sensível e dedicada sabedora das coisas da Bahia, chegou quase no fim, mas ainda me ensinou, e vem ensinando, muito sobre muita coisa. Alejandro Andreassi Cieri, esse ítalo-argentino radicado em Bellaterra, me proporcionou discussões intelectuais inesquecíveis em tardes catalãs. Josep-Maria Terricabras me levou ao coração do catalanismo. Diosdado Toledano me fez aprender a respeitar e admirar a capacidade da esquerda internacional na compreensão de conjunturas. Fabien du Stop, antigo secretário do presidente François Mitterrand, me mostrou a concretude disso pelas ruas do quatorzieme. Irene Castells e José Bailo Ramonde, sobreviventes da guerra civil espanhola e da brutalidade do franquismo e do império da mediocridade do pensamento único hodierno, me deixam simplesmente sem palavras para expressar minha admiração e honra em tê-los como amigos e interlocutores transatlânticos.

Com tanta gente de proa ao meu encalço, só posso ser eu mesmo o responsável por eventuais desvios e enganos e incoerências e imprecisões.

O geógrafo Antonio Carlos Robert Moraes, o embaixador Rubens Ricupero, os historiadores João Luis Ribeiro Fragoso e Elias Thomé Saliba, juntos com a orientadora 
Maria Inez Machado Borges Pinto, examinaram e aprovaram este estudo-tese, numa agradável tarde de outono de 2012, o 20 de abril, dando mostra do mais agudo e franco e penetrante brilhantismo acadêmico e intelectual, predicados progressivamente ausentes ou insipientes ou desprezados e maltratados nos contextos acadêmicos e intelectuais absolutamente desencantados que vivemos no Brasil e mundo afora.

A Coordenação de Aperfeiçoamento de Pessoal de Nível Superior, a Fundação de Amparo à Pesquisa do Estado de São Paulo e o Programa Mobilidade Internacional da PróReitoria de Pós-Graduação da USP-Banco Santander franquearam todos esses anos de pesquisa, estudo e formação.

Devo agradecer aos amigos e colegas que partilharam comigo três gestões de representação discente nos conselhos universitário e de pesquisa da Universidade de São Paulo. Jamais esquecerei a generosidade dos amigos e colegas da Maison du Brésil e da Maison d'Argentine que me elegeram membro do Conseil d'administration de la Cité Internationale Universitaire de Paris. Hamza Hjyej, que dividiu liderança comigo, foi cortês mesmo em momentos em que nossa discordância era integral. Não menos afáveis foram vários de meus colegas e amigos da Rede de Brasileiros na Europa, da Rede de Brasileiros no Mundo e da Associação de Pesquisadores e Estudantes Brasileiros na Catalunha. Marco Antonio Ribeiro Vieira, desgarrado de casa na charmosa Milão, segue parceiro nas quebradas do mundo e do Brasil. Nas encruzilhadas dos acasos dos dias, várias outras pessoas se mostraram essenciais. Fábio Leão e Hiroshi de Sandes me encheram de bière nas muitas noites de Paris sonhando estar em São Paulo ou Fortaleza. Stefano Mascia e José Luis Garcia, de foster's, nas de Londres querendo estar nas da Sardigna ou de Madrid. Nancy Doherty facilitou em muito minha vida no Reino Unido. Marino Pesce, na 35 Buckingham Road em Londres. Ana Mallada e Ana Vilar, em Barcelona. Viviane Briccia, em Valência. Marianna Cancela, em Lyon. Isabela Fadul e Maurício Freire, em Salvador. Fabrício Marques, no Rio de Janeiro. Henrique Coelho Hernandez, em Ourinhos. Carlos Roda e Fabiano Faridi e Admir Rubens Zarpellon, em vários cantos do Paraná. Paola Giacomoni vem me mostrando o quão grave tudo em italiano pode ser. Marion de Maury encheu de vida e ânimo momentos em que tudo me parecia desabado na nem sempre fácil vie française et européenne. A memória dos dias e a memória das noites em Londres, Dover, Lille, Paris, Tours, Loire e Fontenay-auxRoses seguirão inalteravelmente vivas em mim. Adriana Campos e Hugues Fournier aportaram Buenos Aires e o Quebec duma só vez ao meu encontro. Ahamed H., a Palestina e o mundo árabe. Bruno Marcius, Lucilene Brise e Leandro Thomas de Almeida me fizeram 
acenos de afeto em dias turvos pela Europa. Clenes Louzeiro, Daniel Huertas e Eliseu Gouveia me fazem acenos de afeto nos dias turvos pelo Brasil. Carlos Arbieto e Jalmar Carrasco puseram cheiros de Cusco e sabores de Lima em meus sentidos. Caroline Reis Bueno me acompanha e incentiva de modo incondicional desde os tempos do onça. Altair dos Santos, Marciano do Vale e o Potchego são irmãos mais velhos que não tive que acreditam em mim em momentos que inclusive eu me desacredito. Tiago Inocêncio me ajuda a diminuir o vazio irreparável que o desaparecimento de nosso amigo-irmão Samuel Choaire Sanches deixou. Elanir Carvalho ainda não sabe muito bem o que faço, mas soube como me fazer feliz. Maria Rachel Dias também não sabe o que faço, mas segue me fazendo feliz. Sérgio Motejunas Ramos segue meu manito viejo de guerra. Júlio Couto, quem melhora minhas ideias. Ricardo Ortiz, quem põe luz e som e vida e gente em minhas convicções. Fernando Neves, amigo apesar dos contrários. Henrique Antonio Ré, referência de honestidade e determinação. Anderson Lino, meu amigo eterno. Minha avó, dona Sebastiana, razão de tudo. 


\section{A obsessão da capital}

Ahi quanto a dir qual era è cosa dura.

Dante Alighieri, Comédia (Inferno, I, 4).

Écrire est un déchirement, une obscure damnation.

Ernesto Sabato

Tout comprendre, c'est tout pardoner.

Irlanda, novembro-dezembro de 1710. René Duguay-Trouin, oficial da marinha real francesa, preparava sua esquadra para emboscar cargueiro inglês vindo da Índia quando começaram a chegar as notícias do fracasso da expedição de Jean-François Duclerc no Rio de Janeiro. O comandante Duclerc, nascido em Guadalupe e também oficial da marinha da França, na liderança de pouco mais de oitocentos homens, acessara a baía de Guanabara no dia 17 de agosto próximo passado com clara intenção de afanar riquezas em ouro e víveres que aquele porto escoava aos montes. Por subestimar, ou desconhecer em detalhes, a força de combate das milícias locais, acabou facilmente interceptado e aprisionado e ampla e duramente humilhado. Seus homens mais ordinários foram encarcerados pela casa da moeda e pelos conventos e mosteiros da cidade. Os mais graduados e sofisticados e, por isso, considerados perigosos foram enviados para Bahia e Pernambuco. Duclerc ficou dias no colégio dos jesuítas e dias no forte de São Sebastião. Por novembro-dezembro, foi enviado para uma casa-prisão nas proximidades do centro da vila. Por novembro-dezembro, os colonos luso-brasileiros ainda promoviam festas para comemorar a vitória sobre o vilão e sobre, simbolicamente, a França. Não era a primeira vez que bandeiras daquele reino rival do português acessavam terras e mares daquele domínio americano ibérico. Milhares de milhas dali, Duguay-Trouin, horror dos navios de sua majestade inglesa desde 1704, recebeu essas más-novas como argumento-justificativa para pôr em marcha seu antigo desejo de atravessar o Atlântico e ver de perto a pujança dessa cidade-mundo que era o Rio de Janeiro que havia mais de dez anos alimentava de ouro a capital de sua metrópole, Lisboa-Portugal, e as capitais 
dos inimigos do rei de França, Londres e Amsterdam. Sem nenhuma hesitação, esse já afamado corsário francês retornou à França e à sua Saint-Malo para organizar a empresa. A essa altura, o sentimento de honra ferida cobria todo o reino do rei Louis XIV. Corria boca a boca o tratamento nada cortês que os prisioneiros franceses vinham recebendo nas terras do Brasil. Era dito que alguns, inclusive, estavam a morrer de sede e fome. Nesse ambiente, não foi custoso a Duguay-Trouin, de imediato, localizar fiadores para seu empreendimento. Sob o suposto de fazer honrar o nome da França, seis empresários de Saint-Malo se prontificaram em financiar a expedição. Três desses avalistas, amigos do agora comandante desde os tempos de seminário, muito antes de Duguay-Trouin decidir pela marinha, foram designados diretores de armamento. Com a intercessão do rei, milhares de voluntários foram recrutados por toda a França. Muitos vinham sem nem mesmo ser chamados. Soldados especializados dispersos pelos mares de Holanda, Portugal e Espanha foram convocados em caráter de urgência. Oficiais em comando, dispostos nos mais diversos portos de França e de aliados de França, foram instados. Nesse momento, 1711 já entrado em meses, chegou o informe da morte do comandante Duclerc no Rio de Janeiro. Nenhuma explicação alteraria esse fato. E, diante do fato, a ira dos franceses só fez aumentar. A notícia dessa grande expedição em vingança foi se espalhando às rápidas por todo o espaço europeu. Em fins de maio, Duguay-Trouin, que fazia de Brest seu centro de comando, decidiu partir às pressas ao saber que uma armada inglesa se preparava para vir ao seu encontro. Assim, no dia 2 de junho, partiu de Brest rumo La Rochelle, de La Rochelle para Rochefort, de Rochefort para as Ilhas Canárias - por certo, Tenerife. Mês e pouco depois, 17 navios com 700 canhões, 10 morteiros e mais de cinco mil e quinhentos homens iniciavam sua rota para os trópicos. Sua aventura em terras do Brasil.

O resultado dessa expedição alteraria definitivamente a relação entre Portugal e essa importante cidade de seu domínio americano que era o Rio de Janeiro.

Ainda em águas profundas do Atlântico, Duguay-Trouin conferenciou com os demais comandantes a alternativa de fazer escala na cidade da Bahia e bombardear todos os navios de bandeira inimiga antes de partir para o Rio de Janeiro. A ideia foi perdendo força ao passo que os dias iam passando e a tripulação, se estressando diante da lentidão que ventos contrários impunham ao deslanchar das naus. O risco de eventual derrota também era cogitado. Naqueles anos de guerra de sucessão ao trono de Espanha, que era um conflito de dimensão internacional, a marinha francesa vinha amargando duros malogros. Era grande o receio de perder mais homens, navios e dinheiro. Optou-se pela objetividade.

Direto ao alvo, em começos de setembro, os soldados da França avistaram as terras do Brasil. Na manhã do dia 12, estavam a postos para adentrar a Guanabara. O tempo estava feio. 
Escuro. Cheio de nevoeiro. Prenúncio de chuva, soluços de chuvisqueiro. O governo da capitania estava a par dos acontecimentos. $\mathrm{O}$ rei da Inglaterra mandara avisar. Sem mesurar o que aguardavam, brasílicos aguardavam a postos a chegada do vingador. Durante as mais de quatro horas, dispensadas para as gigantes e modernas naus francesas acessarem os perímetros do Rio de Janeiro, ocorreram arremedos de resistência. Tropas da cidade canhonearam ato contínuo os navios de Duguay-Trouin. Cerca de trezentos homens franceses vieram a pique. Um e outro navio teve uma e outra parte danificada. Nada mais. A marinha e os soldados locais foram silenciados. Gamboa e ilha das Cobras foram feitos pontos de ancoragem do invasor. No 13 e no 14, a cidade foi bombardeada e definitivamente sitiada. 500 homens do nobre malfeitor foram, em primeiro ato, desembarcados em terra. Outros quase cinco mil seguiam alerta. Mais de três vezes o contingente de soldados a disposição da cidade do Rio de Janeiro que não possuía que 12 mil pessoas como população. Com medo, pavor e ódio, o governador geral da capitania autorizou a deserção de seus homens de guerra e estimulou os moradores a também desaparecer. Qualquer tentativa de reação produziria tragédia ainda maior. No dia 14, em meio a uma tempestade que havia muito não se via em terras do Brasil e de Europa, Duguay-Trouin foi a solo e decretou a cidade oficialmente sequestrada. 2 milhões de libras francesas foi o preço do resgate pago, mais de 50 dias depois, em 600 quilos de ouro, 610 mil cruzados portugueses, 100 caixas de açúcar, 200 bois e dezenas de escravos. ${ }^{1}$

O empreendimento rendeu lucro de praticamente $100 \%$ ao corso francês. A operação foi um sucesso. Tratou-se, basicamente, da melhor empreitada da marinha do rei Louis XIV. A humilhação imposta aos súditos da coroa portuguesa em domínio americano foi das maiores até então. A importância do Brasil e do Rio de Janeiro foi posta em discussão. Portugal e Reino Unido pautaram em conjunto a questão. O melhoramento do sistema de segurança da cidade foi precipitado. Portos foram reforçados. Muralhas, construídas. Número de soldados, aumentado. O próprio povoamento foi incrementado. Nos anos que se seguiram não se fez outra coisa que valorizar esse endereço que, desde o século anterior, representava uma das mais importantes rotas de comércio do Atlântico sul. Era o elo forte entre Luanda e

\footnotetext{
${ }^{1}$ Jeanne Françoise OZANNE - Recueil des combats de Duguay-Trouin. N. Ozanne delineavit, Jna. Fca. Ozanne sculpsit. Paris: Chez le Sr. le Gouaz, graveur [1734?]. René DUGUAY-TROUIN - Relation de ce qui s'est passé pendant la campagne de Rio de Janeiro. Angers: Chez Jean Hubault, 1712. Memoires de monsieur du Guay Trouin, Lieutenant Géneral des Armées Navales de France et Commandeur de l'ordre Royal \& Militaire de Saint Louis, 1740. Robert SOUTHEY - História do Brasil. Trad. Luis Joaquim de Oliveira e Castro. Rio de Janeiro: Garnier, 1862. pp. 143-4. Sebastião da ROCHA PITA - História da América portuguesa. Bahia: Imprensa econômica, 1878. p. 394. José de Sousa Azevedo PIZARRO E ARAÚJO - Memórias históricas do Rio de Janeiro. Rio de Janeiro: Imprensa Nacional, vol. 1, 1945. p. 165. Charles BOXER - The Golden Age of Brazil, 1695-1750. Berkeley: University of California Press, 1964. Cap. 4. Antonio TORRES - O nobre sequestrador. Rio de Janeiro: Record, 2002.
} 
Buenos Aires. ${ }^{2}$ Era o encontro desses mundos numa fase de diminuição relativa da acuidade do cultivo de açúcar face à exploração do ouro. A relevância econômica se somou à política.

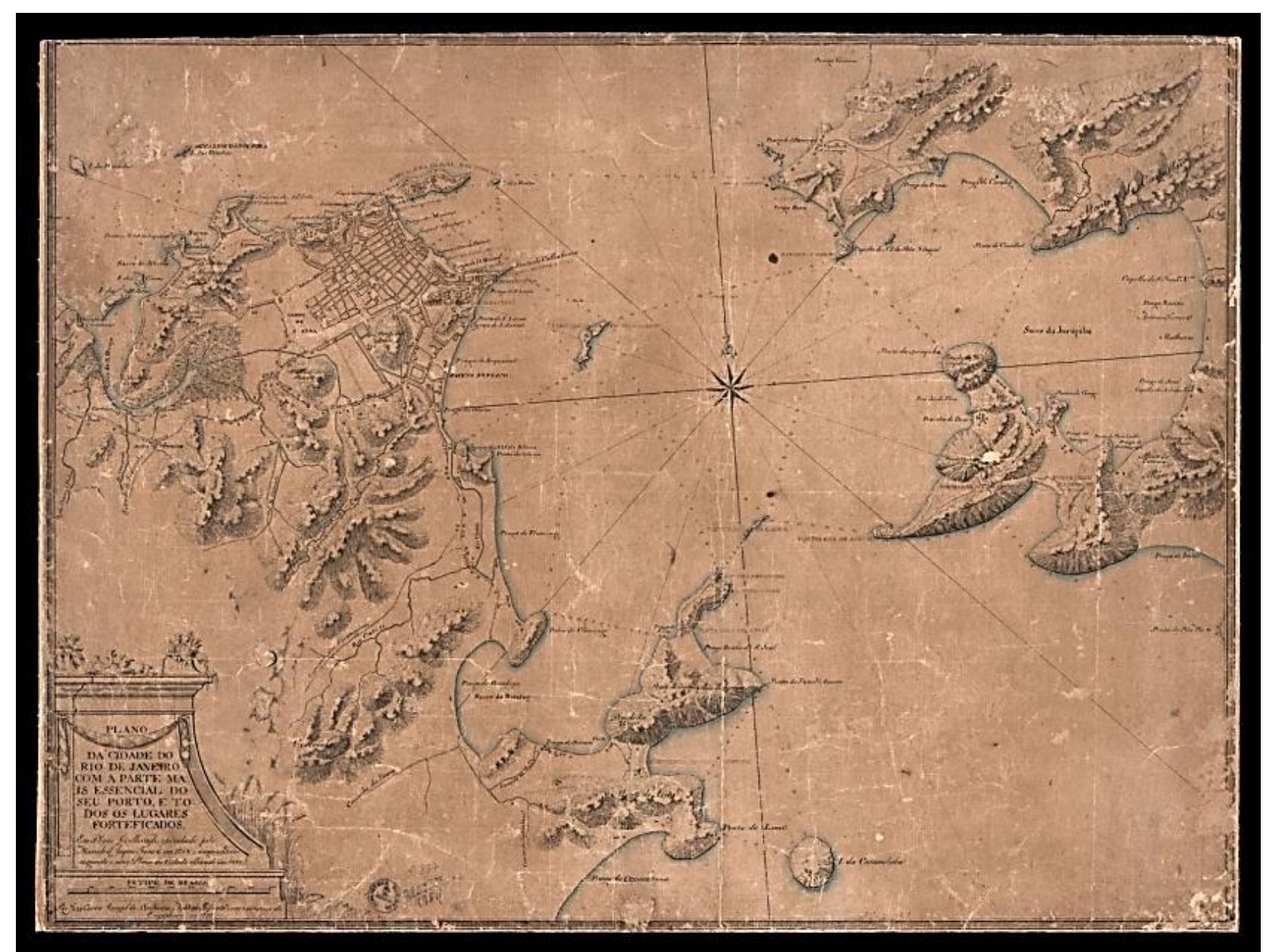

Plano do Rio de Janeiro

O Rio de Janeiro passou a jurisdicionar com maior presença as praças do sul. Começou a administrar positivamente a atuação das gentes das minas de Goiás ao Sacramento. A fundação do tribunal de justiça, a relação, em 1751, no Rio de Janeiro, foi um trajeto quase natural. O judiciário geral da colônia centralizado na cidade da Bahia, a São Salvador da Bahia de Todos os Santos, era mais e mais improcedente. Ir até lá ficou longe e perigoso. Por vez, caro.

Em 1763, a cidade do Rio de Janeiro virou capital.

\footnotetext{
${ }^{2}$ Luiz Felipe de ALENCASTRO - $O$ trato dos viventes: formação do Brasil no Atlântico Sul. São Paulo: Companhia das Letras, 2000.
} 


\section{Desatinos}

Impera certo consenso analítico absoluto acerca da necessidade e da importância da mudança do vice-reinado da Bahia para o Rio de Janeiro em 1763. O argumento mais recorrente supõe que a Bahia amargava decadência econômica e social e representativa ao passo que o Rio de Janeiro ascendia em todos esses e outros aspectos. ${ }^{3}$ Com a vinda da família real para o Brasil em 1808, o esplendor fluminense só fez aumentar. Com o avançar dos oitocentos, a desgraceira baiana só fez se afirmar. Essa linha cruzada foi se aprofundando ao longo do século XX. O enigma baiano enquanto debate segue fortemente lastreado nesse paralelo. A perda de centralidade do, hoje, norte e nordeste frente ao sul e sudeste foi ganhando materialidade inconteste. Entretanto, pelos idos de 1763, eventual centralidade do Rio de Janeiro em detrimento da centralidade da Bahia deve ser observada como algo, no mínimo, discutível. O centro administrativo do império português, sob a direção do secretário Sebastião, futuro conde de Oeiras, futuro marquês de Pombal, parece não ter admitido essa tese. A decisão de mudar a capital para o Rio de Janeiro, ao que tudo indica, não resultou de longa discussão ou reflexão ou pauta. Fôra na corte em Lisboa, fôra nas câmaras municipais pelo Brasil. Desde que assumira o cargo de secretário de estado do reino em 1750, o dr. Sebastião foi consumido por demandas europeias. Mesmo o contencioso Sacramento, dos mais delicados daqueles anos, foi delegado quase inteiramente ao enviado especial que era o governador Gomes Freire de Andrade, o conde de Bobadela. O sismo de 1755 e a guerra dos sete anos foram que ocuparam mais tempo e paciência dos homens do rei José na corte lusitana. Em terras do Brasil, somente muito tempo depois da mudança da capital, provavelmente nos fins dos setecentos, que a importância do Rio de Janeiro foi absorvida pela consciência coletiva. ${ }^{4}$

O ponto de partida deste nosso estudo partia do consenso. Acreditava profundamente na decadência da Bahia e no aumento irresistível da importância do Rio de Janeiro. E, com isso, sugeria abordagem pretensamente inovadora. Queria pôr história no ressentimento que a transferência da sede administrativa havia eventualmente causado aos baianos que perderam o estatuto e a condição material de moradores da capital. Baseado em pesquisa anterior que

\footnotetext{
${ }^{3}$ Stuart SCHWARTZ - Segredos internos: engenhos e escravos na sociedade colonial, 1550-1835. São Paulo: Companhia das Letras, 2000. pp. 80 ss. Maria Fernanda BICALHO - As noções de capitalidade no Rio de Janeiro sob a política pombalina. In.: Ana Cristina ARAÚJO; José Luis CARDOSO; Nuno Gonçalves MONTEIRO et all (Org.). O terremoto de 1755: impactos históricos. Lisboa: Livros Horizonte, 2007. Maria Fernanda BICALHO - A cidade e o império: o Rio de Janeiro no século XVIII. Rio de Janeiro: Civilização Brasileira, 2003.

${ }^{4}$ Kátia MATTOSO - Au nouveau monde: une province d'un nouvel empire: Bahia au XIX siècle. Histoire, économie et societé, 4ème trimestre, pp. 535-69, 1987.
} 
resultou no meu Histórias de Bahia, Histórias de Brasil ${ }^{5}$, estava muito convencido da força do ressentimento baiano no pós-independência. Especificamente de 1823 a 1838. Com um controle razoável da história política e social do 2 de julho à Sabinada, acreditava que a raiz de tudo - do ressentimento, da miséria, da opulência, da indiferença, do esnobismo baianos estava na mudança da capital. Seguia a tendência analítica que entende que a perda da capital foi um duro golpe na sociedade baiana. Passei muito tempo enfeitiçado por essa avaliação. Como a história do Histórias de Bahia, Histórias de Brasil esteve profundamente contaminada pelos bordões formação da identidade nacional brasileira, formação o estado e da nação, crise do antigo regime, para ser coerente, acreditava que a transferência da capital havia produzido certa distorção lógica na percepção baiana das coisas. Julgava que o ressentimento proveniente do pós-1763 havia conduzido os baianos a progressivamente negarem Portugal e Brasil-Rio de Janeiro como núcleos de peregrinação política e identitária. Nesse sentido, a conjuração dos alfaiates (1789) e a guerra de independência (1823) e abdicação de d. Pedro I (1831) e a revolta separatista liderada por Francisco Sabino (1837-8) eram mostras claras e fortes do cartão vermelho que os baianos davam ao outros. 1789 e 1823, contra Portugal. 1831 e 1837-8, contra o Brasil encarnado no Rio de Janeiro. Tinha para mim que esse ressentimento alimentava profundo e insuperável localismo. Que os baianos do pós-1763 não admitiriam outra identidade que não a sua própria. Ou seja, que mais e mais abdicariam se ser baiano-portugueses para se admitir baiano-baianos e nunca baianobrasileiros. E que aí estaria uma das chaves de compreensão da ausência de unidade nacional brasileira.

Nos cadinhos da identidade e da política, o frágil da proposta não eram tanto suas hipóteses, mas seus supostos de história.

\section{Novos rumos}

Analisando mais de perto a situação da colônia e da corte em Lisboa no momento da transferência da sede do vice-reinado, ficou patente certa indiferença por parte dos administradores dos dois lados do Atlântico com relação ao assunto. Nenhum acontecimento de importância teve lugar em Portugal, no Rio de Janeiro ou na Bahia por conta ou em favor

\footnotetext{
${ }^{5}$ Daniel Afonso da SILVA - Histórias de Bahia, Histórias de Brasil: cinco estudos sobre a crise do primeiro reinado na Bahia (1828-1831). São Paulo, 2007. (Dissertação apresentada ao programa de pós-graduação do departamento de História da FFLCH-USP)
} 
da mudança da capital. Contrárias às aparências e às insinuações, esse foi que foi o fato. E esse fato me fez alterar a direção da análise e as convicções sobre o fato. Ao invés de observar o depois da transferência, procurei, questionando internamente o saber estabelecido, entender suas razões. Começando, então, pelo imediatamente antes. Sem perder de vista estruturas de longue durée. Esse antes correspondeu à perda da colônia de Sacramento nos fins de 1762 e à morte do governador Bobadela, no início de janeiro de 1763, isso na colônia, e aos momentos finais da guerra de sete anos entre os titãs europeus além-colônias. Intrinsecamente relacionados, esses incidentes concorreram fortemente para a decisão de se mudar a capital para o Rio de Janeiro. Não necessariamente em razão de o Rio de Janeiro estar supostamente em posição privilegiada para proteger fronteiras coloniais, nem tampouco por eventual decadência da capital antiga que era a cidade da Bahia. Mas por razões menos óbvias e pouco frequentadas.

Ao perceber que a morte iminente do rei Fernando da Espanha poderia pôr fim ao tratado de limites de 1750, o secretário Sebastião de Portugal ordenou que o governador Bobadela, comissário português responsável pela demarcação das fronteiras dos domínios de Portugal e Espanha no sul das Américas, retornasse ao Rio de Janeiro. Após mais de sete anos nas ásperas terras do sul, o nobre governador reassumiu o governo da capitania do Rio de Janeiro nos inícios de 1759. Ano e pouco depois, a morte do conde de Lavradio, vice-rei do Brasil sediado na cidade da Bahia, produziu certo simbólico e metafórico vazio de autoridade na colônia. Ou ao menos. Sobretudo porque os membros do governo interino não se entendiam e batiam cabeça. Seus desentendimentos eram permanentes. Ciente da situação, o secretário Sebastião orientou o rei José a nomear, em 1761, o governador Bobadela vice-rei do Brasil na Bahia.

O distinto governador não só não atendeu à determinação real como demorou quase um ano para se justificar. Disse ser imperativo ficar no Rio de Janeiro. Seu objetivo era continuar vistoriando as ações no sul.

Dias depois da capitulação em Sacramento, Bobadela veio a morrer. Para muitos, de desgosto. Entre o primeiro e o segundo quartos de 1763, o rei José nomeou outro governador para o Rio de Janeiro. Esse novo governador acumularia a função de vice-rei. Por isso e por conta disso, o secretário Sebastião determinou que a capital fosse mudada para o Rio de Janeiro.

Essas decisões, hesitações e preocupações estiveram marcadas, no geral e no específico, por cálculos políticos forjados pela situação de guerra e pela presença dos 
representantes dos principais países em combate, França e Inglaterra, na corte lusa. Desde o início da gestão do secretário Sebastião, sua relação com os diplomatas desses países vinha sendo intensa. Entretanto, a partir de 1757-8, ela se tornou determinante. Por vez, asfixiante. Edward Hay, embaixador inglês em Portugal de 1757 a 1763, influenciou enormemente a formulação da política interna e externa portuguesa nos tempos de guerra. Ele teve papel decisivo, por exemplo, na nomeação e na orientação do envio do governador Bobadela como vice-rei para a Bahia em 1761. Do lado francês, o conde de Merle, embaixador do rei Louis XV em Portugal entre 1759 e 1761, talvez tenha sido o mais indesejado enviado estrangeiro na corte lusa naqueles anos. O secretário Sebastião chegou a declará-lo inimigo infiltrado. Cortou relações. Deixou de lhe falar. Fez de tudo para lhe impor zarpar. Seu objetivo, o de Merle, foi, no fundo, ofuscar a tomada de decisão dos ministros portugueses com relação ao conflito. O contexto de guerra, e as audiências permanentes com esses e outros enviados diretamente interessados na guerra, conduziu o secretário Sebastião a se afastar, quase definitivamente, dos negócios do Brasil.

O governador Bobadela era o representante dos mais importantes do império luso nas Américas. Sua morte em 1763 deixou um vazio imenso. Irreparável. Quase impossível de suplante. Pior que isso, a partir dali, as principais capitanias da colônia, assim como a própria colônia, estavam sem governo estável. O secretário Sebastião se viu num dilema. Esses dois centros - Bahia e Rio de Janeiro - possuíam densa comunidade política e necessitavam de um administrador com, entre outras coisas, autoridade política e nobiliárquica provadas. A ausência de gente com esse perfil disponível era uma realidade. O conde da Cunha, escolhido para vice-rei do Brasil em 1763, era o irmão do secretário Luiz da Cunha. Luiz da Cunha era o responsável pelos negócios estrangeiros do reino. Servia como espécie de homem 2 ou 3 do rei José. Seu irmão, o conde da Cunha, também por isso, tinha muita influência na corte. Em 1760 fôra fortemente cotado para substituir o embaixador português em Paris. Chegou, inclusive, a ser entrevistado por Merle. Merle, que tinha tido problemas pessoais com o então enviado português na França, o abade Salema, insistira, durante todo o período que esteve em Lisboa, para os ministros lusos nomearem o conde da Cunha para Paris. O rei José chegou a nomear, mas o secretário Sebastião forjou mudança de ideia. Como foi o secretário Sebastião que fez o rei José mudar de ideia com relação ao destino do novo vice-rei no Brasil. Por isso, o conde da Cunha, ao invés de ir para a Bahia, foi para o Rio de Janeiro. 
De modo objetivo, as razões dessa mudança seguem um mistério. Ou, ao menos, um suspense. Não sobrou, ou não foi encontrado, nenhum documento "eloquente" sobre o fato. ${ }^{6}$ Com o intuito de conferir maior inteligibilidade ao assunto-mistério-suspense, examinei a documentação política e diplomática de Portugal, Espanha, França e Inglaterra referentes ao Portugal e ao Brasil de 1750 a 1763. Para o caso de Portugal e Brasil, cartas régias, cartas e ofícios do secretário Sebastião, cartas e ofícios dos governadores de Bahia e Rio de Janeiro, correspondência e ofícios do conselho ultramarino. Nesse quesito, lancei mão, entre outros, de diversas coleções do acervo do Centre Culturel Calouste Gulbenkian em Paris. Ainda na e sobre a França, analisei todo o fundo Mémoires et documents - Portugal do Archives du ministère des affaires étrangères onde existe documentação referente a missões francesas em Portugal e missões portuguesas na França. Para o caso do Reino Unido, analisei especialmente os State Paper Foreing - Portugal, 89 e State Paper Foreing - France, 78, parte do acervo do The National Archives em Londres. No Brasil, compulsei informações dispersas em diversas bibliotecas e arquivos, públicos e privados, espalhados por São Paulo, Rio de Janeiro, Minas Gerais e Bahia. Alguns foram especialmente fundamentais e merecem destaque. Na Bahia, o Arquivo da Cúria Metropolitana, o Arquivo Municipal de Salvador, o Centro de Documentação e Informação Cultural sobre a Bahia da Fundação Clemente Mariani, o Centro de Estudos Baianos, a Fundação Pedro Calmon - Centro de Memória e Arquivo Público do Estado da Bahia e o Instituto Geográfico e Histórico da Bahia. No Rio de Janeiro, o Arquivo Histórico do Itamaraty, o Arquivo Nacional, a Biblioteca Nacional, o Instituto Histórico e Geográfico Brasileiro e o Real Gabinete Português de Leitura. Em São Paulo, o Instituto de Estudos Brasileiros, a Casa de Portugal e acervos da Universidade de São Paulo, da Pontifícia Universidade Católica e da Universidade de Campinas. Em Minas Gerais, o Arquivo Público Mineiro. No espaço virtual, frequentei essencialmente a Biblioteca Digital do Senado http://www2.senado.gov.br/bdsf, o Arquivo Público Mineiro http://www.siaapm.cultura.mg.gov.br, o Centro de Memória Digital http://www.cmd.unb.br/resgate_busca.php, os Anais da Biblioteca Nacional http://objdigital.bn.br/acervo_digital/anais/anais.htm, a Brasiliana Eletrônica http://www.brasiliana.com.br, o Center for research libraries global resources network http://www.crl.edu/brazil, o Instituto Histórico e Geográfico Brasileiro http://www.ihgb.org.br/rihgb.php?s=p, o Instituto Brasileiro de Geografia e Estatística www.ibge.gov.br e Gallica, Bibliothèque numérique - http://gallica.bnf.fr .

\footnotetext{
${ }^{6}$ Maria Fernanda BICALHO - As noções de capitalidade no Rio de Janeiro sob a política pombalina. In.: Ana Cristina ARAÚJO; José Luis CARDOSO; Nuno Gonçalves MONTEIRO et all (Org.). O terremoto de 1755: impactos históricos. Lisboa: Livros Horizonte, 2007.
} 
Notícias geográficas

Antes de ensaiar pôr história em tudo que vou aqui suponto, convém referir pontos de geografia. Em passagem sutil de seu discreto Espaço e Método, Milton Santos distingue lugar de local-localização. Lugar, esclarece, é o ponto, a paisagem, o fixo. Local-localização, do contrário, fica aos sabores da força social. Nas palavras do mestre, "é um momento do mundo". 7 Essa distinção, pão de cada dia dos geógrafos e absolutamente descartada do cardápio dos não-geógrafos, aporta explicações decisivas. De olho no mapa, o lugar tende a monopolizar a visão do geógrafo enquanto o local, a dos outros. São Salvador da Bahia e Rio de Janeiro, antes de ser localizações de capitais, são lugares. Suas particularidades sempre foram e serão manifestas. A baia da Bahia e a baia da Guanabara são realizações naturais insondáveis. Sua utilização, especialmente na condição de capital, levou e leva em muita conta essa particularidade estratégica. Que, na condição de estratégica, se mutaciona em local.

Estar perto de portos e baias, como observou esse extraordinário antes e acima de tudo grande prosador que é o historiador Eric Hobsbawm, "era estar perto do mundo". 8 A história, que veio para as Américas em caravelas, transformou as cidades voltadas para o mar em locais importantíssimos do mundo da colonização. A cobiça de inimigos e a voracidade de bandidos foram sempre contra locais. Lugares que a presença humana transformou em importantes.

De olho no mapa, a sensibilidade dessas definições ganha sentido todo especial. A cartografia, mesmo a colonial, tende a projetar os lugares. Mas as cartas não são fim em si. Têm intencionalidades e servem intenções. Quem tomava, e toma, decisão via, e vê, nas cartas locais. Isso era tão evidente para homens de decisão metropolitanos e coloniais que chega a ser constrangedor debater. A visita do "nobre sequestrador" René Duguay-Trouin ao Rio de Janeiro diz mais que qualquer palavrório.

Entretanto, a consciência dessa distinção não necessariamente se traduzia em ação proativa imediata. Malgrado toda a referência que os homens de Lisboa tinham dos melhores pontos de suas costas americanas, contingências de gestão, muita vez, impuseram aos locais a dura realidade de ser lugar. A vulnerabilidade das cidades portuguesas viradas para o mar nas

\footnotetext{
${ }^{7}$ Milton SANTOS - Espace et méthode. Trad. Marie-Hélène Triercelin. Paris: Publisud, 1989. p. 6.

${ }^{8}$ Eric HOBSBAWM - A era das revoluções. Europa 1789-1848. Trad. Maria Tereza Lopes Teixeira e Marcos Penchel. 16. ed. São Paulo: Paz e Terra, 2002. p. 26.
} 
Américas era vexatória. O oficial francês só fez comprovar o saber sabido da época acumulado por anos de insegurança.

O que se viveu no Brasil durante os 13, 14 primeiros anos de reinado do rei José e gestão do secretário Sebastião, período de análise de nosso estudo, foi algo terrivelmente similar.

Notas de cabotagem

Mas não necessariamente essa inseguridade crônica impôs a mudança do vice-reinado da Bahia para o Rio de Janeiro em 1763. Antes de tudo, o contexto desses anos do rei José e do secretário Sebastião foram de guerra. O convício diário com a iminência da défaite conduziu essa administração a ter imensas dificuldades em ir ao encontro de seus locais americanos. Isso em detalhes vai estudado na Parte II - Insones. Na Parte I - Sonâmbulos o objetivo não é outro que indicar como a gente de decisão na colônia - na Bahia, no Rio de Janeiro e no Brasil - ia se virando na ausência presente dos homens de Lisboa. O contencioso Sacramento, por certo, chamou imensamente a atenção de Portugal. A salvação era a existência do nobre governador Bobadela. Sua ida ao sul para negociar a demarcação foi providencial. Seu regresso ao Rio de Janeiro para tudo defender desde aí, essencial. O seu desaparecimento em janeiro de 1763 causou um vazio imenso. Na colônia e no reino. O rei José e o secretário Sebastião perceberam que o Brasil, sem o nobre governador, estava forçosamente sem cabeça. Isso precipitou o envio imediato de um substituto. Que veio com a função de ser vice-rei e com a determinação de morar no Rio de Janeiro. A Bahia, que amargavam quase quatro anos sem governador - que no caso era o próprio vice-rei e o último havia morrido em 1760 sem ser substituído -, perdia sua condição de capital. A discussão geral sobre essa condição de capital vai apresentada na Parte III - Os sentidos da capital. Essa parte, especialmente os capítulos Cidades e Capitais, é, por assim dizer, a hora da verdade da tese. Essa hora, como sempre nos ensinam os antigos, melhor não antecipar.

Os objetivos de tudo que se segue são muito mais ambiciosos que os resultados. Entretanto, o desejo profundo e genuíno do estudo não deixa de ser o simples e modesto exercício de contar uma história. No caso, outra. Logo me dirão se consegui. 
Parte I

Sonâmbulos 


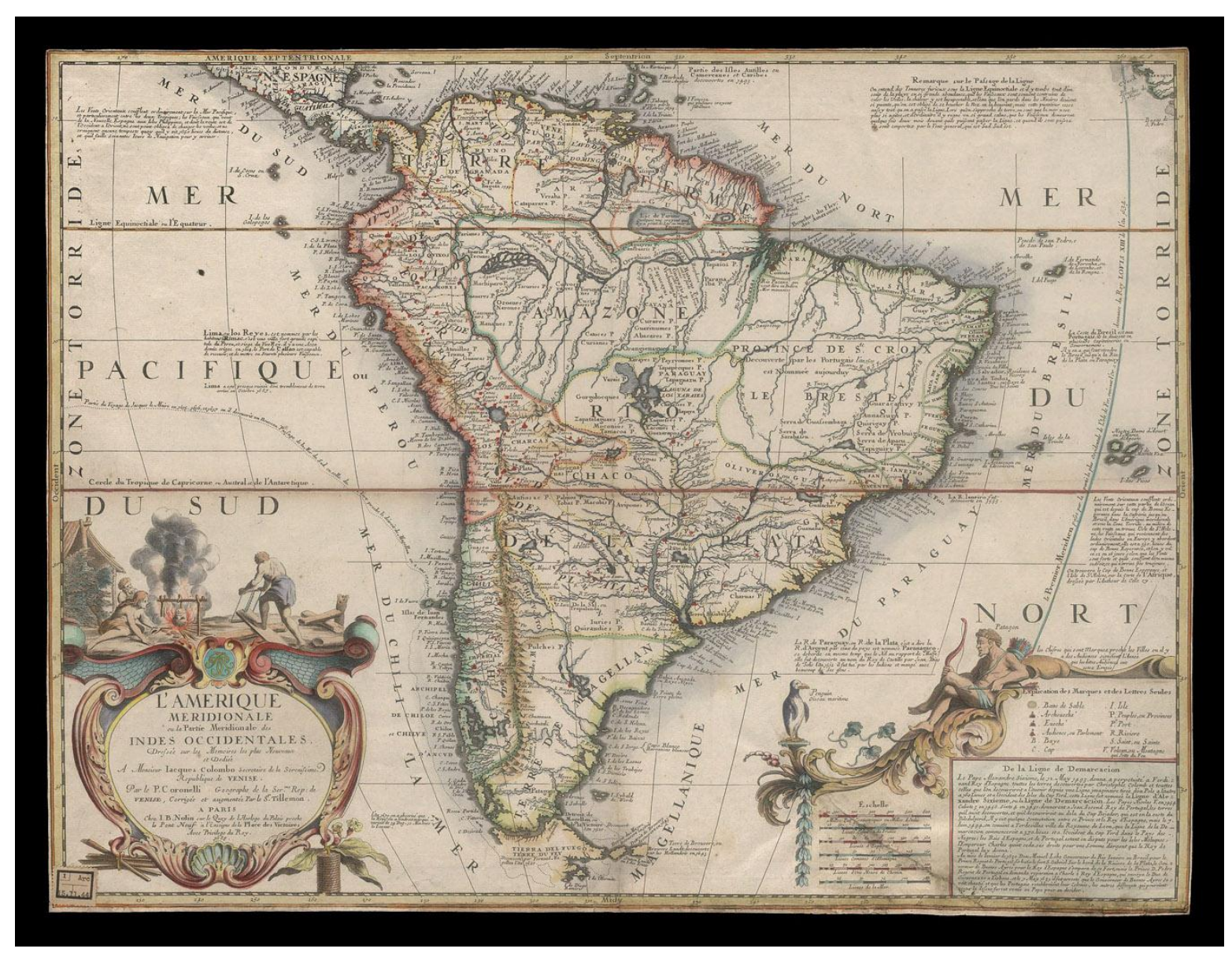




\section{Depois que os sinos dobram}

never send to know for whom the bells tolls; it tolls for thee.

John Donne, Devotions...

Pele após pele! Para salvar a vida, o homem dá tudo que possui.

Jó, 2, 4.

Requiescat in pace

Lisboa, maio de 1763. O rei José I nomeia Antonio Álvares da Cunha, o conde da Cunha, novo vice-rei e capitão geral do estado do Brasil. A decisão saiu em decreto de 11 de maio. ${ }^{1}$ Dois meses depois, a resolução foi comunicada ao governo interino de Rio de Janeiro, Minas Gerais e São Paulo. O informe foi enviado em ofício do secretário de estado do reino e mercês Sebastião José de Carvalho e Melo, que viria a ser conde de Oeiras e marquês de Pombal. Esse ofício carregava outra decisão. Nada convencional. Determinava que a residência do vice-rei nomeado e dos demais seria, doravante, na cidade do Rio de Janeiro. Deixando, portanto, de ser, como sempre fôra, em São Salvador da Bahia de Todos os Santos. A justificativa, contida nesse ofício de 8 de julho, era direta e objetiva: "a conjuntura impõe". Várias autoridades em exercício no sul do Brasil, dizia secretário Sebastião, alertavam para a necessidade de proteção da costa. O Rio de Janeiro conferiria maior segurança. Porquanto, o vice-rei administraria do Rio de Janeiro. Ponto. ${ }^{2}$ A condição estratégica da cidade do Rio de Janeiro era uma realidade. A perda relativa de centralidade e visibilidade da cidade da Bahia também. O sul e suas fronteiras eram preocupação imperativa do reino. O contencioso Sacramento tirava o sono de gestores públicos e privados dos dois lados do Atlântico. Desde muito tempo, essa nova colônia, de frente para Buenos Aires, era regida e protegida pelo governo do Rio de Janeiro. Desde muito tempo, brasileiros e argentinos, portugueses e espanhóis, e todos os seus aliados em todos os continentes, tramavam a posse daquele

\footnotetext{
${ }^{1}$ AHU - Rio de Janeiro, cx. 72, doc. 4.

${ }^{2}$ AHU - Rio de Janeiro, cx. 72, doc. 22.
} 
território. Do lado luso-brasileiro, manter Sacramento era questão de honra. Do lado hispânico, de princípio. De toda maneira, as constantes investidas inimigas causavam insegurança, impotência e medo dos dois lados. Sacramento era mais que prata. Mais que ouro. O secretário Sebastião confidenciou diversas vezes ao antigo governador do Rio de Janeiro, Gomes Freire de Andrade, o conde de Bobadela, seu medo, seu receio e seu cuidado com aquela fronteira. Disse com todas as letras em cartas de 20 e 28 de abril de 1762 a Bobadela, seu fiel amigo e leal subordinado, que seu "maior receio [era] a praça da colônia (...) o grande osso e cuidado do governo". Ela é toda banhada por mar, complementava. ${ }^{3}$ Entre o rio da Prata e o ouro das minas, o Rio de Janeiro seria o ponto estratégico natural para centralizar a administração do território do domínio Brasil. A capital continuar na cidade da Bahia seria, por esse prisma, improcedente. E, portanto, a decisão do rei José e do secretário Sebastião foi aparentemente absolutamente lógica.

Olhando pelo caráter lógico, desde muito antes de 1763, as mesmas condicionantes imperavam. $\mathrm{O}$ ouro das minas era explorado com sucesso havia muitos e muitos anos. $\mathrm{O}$ contencioso Sacramento era secular. Assim como a presença inimiga em costas fluminenses. Sacramento era, talvez, o assunto-problema, fora da Europa, mais ubíquo na agenda dos homens do rei José - especial e francamente liderados pelo secretário Sebastião desde 1750. Piratas e corsários no Rio de Janeiro também. Seguindo nesse raciocínio, houve, evidentemente, procrastinação. Leniência, talvez. A capital deveria de já estar havia tempos no Rio de Janeiro. Entrementes, contendo a ligeireza e a comodidade duma resposta lógica, conviria olhar para a cidade da Bahia. O ouro aparente minorou a importância evidente do açúcar. Isso foi um fato. Em Lisboa ou Paris ou Londres, era essa a impressão e convicção. Mas o ouro, por certo, não destruiu a sociedade que o açúcar bateu. Eventual perda de centralidade da Bahia não era, ao menos à época, sinônimo de perda de importância. Oligarquias de nome e sangue, com brasões banhados em prata e ouro, irrigavam, continuaram e continuam a irrigar, a teia social luso-afro-baiana. A influência dessa gente tornada brasílica na Bahia seguia decisória e decisiva. Os homens de Lisboa o sabiam perfeitamente. A área de abrangência e a força da Bahia e de sua gente era algo incontestável. Esse pode ter sido componente de força para a hesitação na mudança da capital.

Admitindo e avançando no maniqueísmo, o secretário Sebastião estaria, portanto, num impasse. Bahia ou Rio de Janeiro capital? Desconsiderando o maniqueísmo e avançando no cotidiano político do reino em 1750, as condicionantes lógicas vão perdendo força.

\footnotetext{
${ }^{3}$ Apud Francisco Adolfo VARNHAGEN - História Geral do Brasil. Antes de sua separação e independência de Portugal. Notas de Rodolfo Garcia. 8. ed. São Paulo: Melhoramentos, 1975. p. 183.
} 
Atravessando o Atlântico e analisando o cotidiano dos enviados a servir na Bahia, no Rio de Janeiro e algures na luso-América, toda teoria de impasse desaparece completamente. $\mathrm{O}$ secretário Sebastião, ao que consta, não enviou nem recebeu nenhum comunicado abordando o assunto. O secretário do conselho ultramarino, muito menos. Os governadores e os vicereis, menos ainda. Dito diretamente: não houve impasse; houve história.

\section{A dobra dos sinos}

No dia 4 de julho de 1760, Antonio Soares de Almeida Portugal, $1^{\circ}$ marques e $2^{\circ}$ conde de Lavradio, vice-rei e capitão geral de terra e mar do estado do Brasil, desapareceu. Partiu deste mundo. Ele padecia de uma doença incurável e, à época, inominável. "No bofe tinha um tumor da esfera de um ovo coberto de 17 granitos e no fígado tinha duas chagas". 4 Nos dias que correm sabemos que o nome disso só pode ser câncer. Já passava das 20h quando os médicos chegaram à sua casa de campo - de se supor, no recôncavo - e constataram sua morte. A notícia se espalhou e desolou ligeira. Na manhã do dia seguinte, o corpo desse baiano de mais de sessenta anos, arguto e experiente administrador e manejador de gente e de armas, conselheiro do rei e veador da rainha e antigo governador e capitão geral de Angola foi exposto no palácio do governo da cidade da Bahia. ${ }^{5} \mathrm{O}$ cabido, os párocos, os homens da relação, a "nobreza e o povo" se fizeram representar. No fim daquela tarde de 5 de julho, seu féretro seguiu para o convento de São Francisco. Horas depois, Lavradio foi sepultado na capela dos terceiros. "Com toda solenidade que pode caber no possível". 6 Numerosas honras militares. Dobra de todos os sinos. Descarga de tiros, por mais de 40 horas, pela artilharia e infantaria.

Após os tiros, a sucessão.

De imediato, com Lavradio ainda em corpo presente, os trâmites de sua sucessão - a sucessão do vice-rei do Brasil e do governador geral da capitania - foram iniciados. Uma reunião foi convocada. Local: Palácio dos vice-reis. Dia: 7 de julho. Horário: 10h. 36 pessoas foram instadas. Desembargadores da relação, o corpo da câmara, coronéis de infantaria, mestres de campo, religiosos, cinco representantes dos proprietários baianos. ${ }^{7}$ A condução dos trabalhos ficou a cargo do desembargador e chanceler da relação Thomaz Roby de Barros

\footnotetext{
${ }^{4}$ BNRJ - AMU - Bahia, 5083.

${ }^{5}$ Conde de Campo BELO - Governadores gerais e vice-reis do Brasil. Lisboa: Divisão de Bibliotecas e Publicações/Agência Geral das Colônias, 1935. pp. 139-40.

${ }^{6}$ BNRJ - AMU - Bahia, 5083.

${ }^{7}$ BNRJ - AMU - Bahia, 5033.
} 
Barreto e do deão da Sé da Bahia. Ambos, enquanto os sinos dobravam e os tiros rajavam nos dias anteriores, organizaram a pauta da reunião, que versaria sob a resolução real sobre sucessão de vice-reis de 24 de fevereiro de 1754. Essa resolução, guardada no convento da Sé e jamais lida, impunha a composição duma junta provisória que deveria de ser composta pelo arcebispo, o chanceler e o coronel Lourenço Monteiro. Essa normativa rendeu perplexos o chanceler Thomaz e o deão da Sé. Razão: o arcebispo estava "decrépito" e o coronel Lourenço Monteiro, morto. Esse nonsense foi o ponto da reunião. Apresentado sem delongas, o assunto virou debate sem fim. A polêmica era justamente acerca dos nomes para compor com o chanceler o triunvirato que a junta provisória precisava ser. Quanto mais se discutia, mais confuso tudo ficava. E o dia ia indo, indo embora. Perto das 4 da manhã do dia seguinte, por exaustão, decidiram que o chanceler lideraria, até segunda ordem, sozinho o governo interino. ${ }^{8}$

A notícia da morte do vice-rei foi comunicada ao secretário Sebastião em carta do coronel Gonçalo Xavier de Barros e Alvim do dia 13 de julho. ${ }^{9}$ Dois dias depois, o chanceler Thomaz, subscrevendo como governador interino, informou do sucedido ao secretário do conselho ultramarino, Francisco Xavier de Mendonça Furtado, irmão do secretário Sebastião. Comunicou rapidamente da morte e os procedimentos de guardamento de Lavradio, e se delongou nas intempéries da composição do governo interino. ${ }^{10}$ Seis dias depois, no dia 21 , o chanceler-governador enviou outra carta ao secretário Mendonça Furtado descrevendo e explicando mais e mais do ocorrido. ${ }^{11}$

A composição do governo interino, como se deu, mascarou muitos interesses. Contentou certa maioria. Não a maioria. A não escolha de adjuntos para compor com o chanceler-governador Thomaz soou estranha. Mesmo os que apoiaram, o fizeram com reserva. O coronel Gonçalo foi um deles. Claramente descontente e contrariado, acreditava ser um absurdo. Durante a reunião do dia 7 de julho, manifestou amplamente sua posição. Pôs-se como adjunto potencial e, portanto, natural na falta dos indicados na resolução. Afinal, ele era coronel e o trato definia a junta com arcebispo, chanceler e coronel. Dado o avançado da hora e seu claro isolamento na discussão, recuou. Abdicou de politicar em causa própria. Ao menos na reunião. Dias depois, mandou, para o secretário do ultramar em Lisboa, sua versão do

\footnotetext{
${ }^{8}$ BNRJ - AMU - Bahia, 5041; BNRJ - AMU - Bahia, 5033.

${ }^{9}$ BNRJ - AMU - Bahia, 5033.

${ }^{10}$ BNRJ - AMU - Bahia, 5041.

${ }^{11}$ BNRJ - AMU - Bahia, 5083.
} 
sucedido. ${ }^{12}$ No fundo, suas reclamações. Somente elas. De todo modo, da parte do reino fosse do rei José, do secretário Sebastião, do secretário Mendonça Furtado - não houve manifestação. Nada de comentário. Silêncio de lápide. A vida seguiu seguindo. No reino, na colônia e nos domínios. Assim como conflitos e perplexidades.

No dia 28 de abril de 1761, menos de doze meses depois, ocorreu o inesperado. Uma carta régia, assinada em Nossa Senhora da Ajuda, instou o chanceler-governador Thomaz a partir imediatamente para o reino. Pelas normas do chamado, ele deveria se desempossar. Entregar o governo interino e o cargo de chanceler da relação. O novo governo seriam José Carvalho de Andrade e, para surpresa de ninguém, o coronel Gonçalo. ${ }^{13}$ Para alguns, justiça fôra feita. Para outros, vingança. José Carvalho de Andrade era o sucessor do chanceler Thomaz na relação. Portanto, passou a acumular a chancelaria e o governo interino. O coronel Gonçalo acessou como o segundo homem do governo. Ficou ainda faltando a participação da igreja, mancou o arcebispo.

De todo modo, decisão real não se discute. Por isso, o chanceler-governador Thomaz, no dia 31 de julho de 1761, escreveu ao secretário do conselho ultramarino agradecendo. ${ }^{14}$

Desde que assumira o governo interino, a pressão sobre ele, por parte dos baianos, só fez crescer. Homem de importância na colônia, Thomaz Roby passara mais de 20 anos ininterruptos na relação da Bahia. Era um baiano; um brasílico. ${ }^{15}$ Agora, seu regresso ao reino estava por dias.

O novo governo interino, com José Carvalho de Andrade e Gonçalo Xavier Barros e Alvim, começou vivendo controvérsias que se tornaram contradições intermináveis, incomensuráveis e insustentáveis. A luta no poder e por poder era explícita. Andrade, diferente de Alvim, tinha ligações com os homens mais poderosos do reino e da colônia. Do lado de lá, com Mendonça Furtado. Do lado de cá, com o governador Bobadela.

No dia 3 de outubro de 1761, ambos governadores interinos escreveram carta conjunta ao secretário do conselho ultramarino comunicando a partida do chanceler-governador Thomaz. Uma correspondência padrão, formal. Sem muitos floreios. ${ }^{16}$ No dia seguinte, o

\footnotetext{
${ }^{12}$ BNRJ - AMU - Bahia, 5033.

${ }^{13}$ BNRJ - AMU - Bahia, 5322.

${ }^{14}$ BNRJ - AMU - Bahia, 5332.

15 Stuart SCHWARTZ - Burocracia e sociedade no Brasil colonial. A suprema corte da Bahia e seus juízes: 1609-1751. São Paulo: Perspectiva, 1979. pp. 251 ss.

${ }^{16}$ BNRJ - AMU - Bahia, 5629.
} 
novo chanceler-governador Carvalho de Andrade descreveu o coronel-governador Gonçalo, seu colega de função, a Mendonça Furtado, seu superior e amigo.

O coronel-governador, embora importante na Bahia, era semi-desconhecido na corte. O chanceler-governador Carvalho de Andrade, ao contrário, vinha de família conhecida e reconhecida nos dois lados do Atlântico. E, obviamente, bem relacionada. Tanto que, nessa mesma carta do dia 4 de outubro, depois de falar, mal, do coronel-governador Gonçalo, agradeceu longa e intensamente a Mendonça Furtado pelos "favores dispensados a pessoas da sua família". ${ }^{17}$ Sua relação com Bobadela não era das menos fraternas e quentes. No conjunto, suas correspondências ao então governador geral do Rio de Janeiro foram majoritariamente em caráter "particular". ${ }^{18}$ Mostra de sua relação reservada com Bobadela. Ao passo que ao coronel-governador Gonçalo restava o protocolo. Essa desproporcionalidade de relações não tardou a gerar mais confusão, desentendimento, tensão.

No dia 23 de fevereiro de 1762, muito oficiosamente, o coronel-governador Gonçalo escreveu a Bobadela. Comunicou ligeiramente a situação da Bahia. Disse estar tudo tranquilo. Sem "novidades". Mas que ele, o coronel-governador, tinha "grande desejo de deixar o governo". Não suportava mais. Não entrou em muitos detalhes. Apenas fez entender que seria melhor se afastar. Um mês depois, Bobadela deu retorno. Ratificou o pedido. "Permitiu" sua saída. ${ }^{19}$ Entre a Bahia e o Rio de Janeiro, tudo se passou "tranquilamente".

Em Lisboa, o secretário Sebastião em pessoa quis saber que passara. $\mathrm{O}$ chancelergovernador Carvalho de Andrade explicou o mais pronto que pôde. Sintetizou a situação com apenas um qualificativo: "intrometido". O coronel-governador, disse o chanceler-governador, estava xeretando os assuntos da relação. Assuntos públicos, mas não da competência de coronel. Mesmo sendo o coronel, à época, governador. Seu sucessor, o frade Antonio de Santa Ignês, tomou posse de imediato, no dia 1 de agosto. ${ }^{20}$

\section{O Brasil sem cabeça}

De modo geral, o governo interino, imposto pela morte de Lavradio, desde o início, só conheceu crise. Ora de legitimidade, ora de governabilidade. A reunião de 7 de julho de 1760 , insinuou. $\mathrm{O}$ afastamento do chanceler-governador Thomaz, confirmou. A despedida do

\footnotetext{
${ }^{17}$ BNRJ - AMU - Bahia, 5636.

${ }^{18}$ BNRJ - AMU - Bahia, 5765.

${ }^{19}$ BNRJ - AMU - Bahia, 5766-7.

${ }^{20}$ BNRJ - AMU - Bahia, 6000-6001; BNRJ - AMU - Bahia, 6009.
} 
coronel-governador Gonçalo, consumou. Desde Lisboa, o secretário Sebastião e seu irmão estavam completamente cientes e apreensivos. Desde o Rio de Janeiro, Bobadela acompanhava os fatos. Pelo sim pelo não, o núcleo simbólico da administração colonial estava desconjuntado. Sem vice-rei e, por conseguinte, sem autoridade.

Entre a morte de Lavradio e a renúncia do coronel-governador Gonçalo, ocorreu um fato de grande importância. Em notificação de 16 de abril de 1761, o rei José, via secretário Sebastião, mandou Bobadela substituir Lavradio defunto. Ordenou que o governador do Rio de Janeiro fosse para a Bahia na condição de vice-rei. Desde o raciocínio de Lisboa, era claro: ordem dada, ordem cumprida. Em assim se sucedendo, as rusgas e contendas baianas no interior do governo interino estariam com dias contados. E, ao certo, movidos por essa convicção, foi que mandaram chamar a Lisboa o chanceler-governador Thomaz. O afastamento dele datou de apenas pouco mais de duas semanas após a nomeação do governador Bobadela vice-rei. Mas um fator não atendido teve lugar. O Bobadela vice-rei nomeado não respondeu ao chamado e demorou mais de onze meses para se explicar. Seu ofício concernente ao assunto foi enviado direta e exclusivamente ao secretário Sebastião apenas no dia 26 de março de 1762. Sua resposta era não. Sim: Bobadela dissera não ao seu reino e ao seu rei. Ato claro de insubordinação. Teria que ter muito bons argumentos. Muito boas razões. Procurou os descrever em seu ofício. No seu dizer, os "motivos que o impediam de se recolher à Bahia" eram imperativos. Imperativos para o reino, imperativos para o Brasil. Disse Bobadela sem nenhum rodeio que as razões do Brasil estavam nas minas e no Prata. A cobiça pelo Rio de Janeiro só aumentava. Os agravos no território ao sul só se complicava. "Viajar à Bahia seria deixar o Brasil sem cabeça". ${ }^{21}$

O Rio de Janeiro era o centro de tudo. Cidade mais rica, mais segura, mais bem localizada. Essa era a avaliação de Bobadela. Que, possivelmente, aceitaria ser vice-rei; desde que continuasse no Rio de Janeiro.

Bobadela, portanto, recusou ser vice-rei para ficar no Rio de Janeiro.

O secretário Sebastião jamais tocou no tema e, vendo no contexto, inclusive apoiou e reconheceu a decisão e o senso de responsabilidade de seu enviado. Ninguém, ao que consta, protestou a decisão do nobre governador. Ninguém sequer comentou. Desse março de 1762 à nomeação do novo vice-rei do Brasil em maio de 1763, o vazio tomou conta do correio reino-

\footnotetext{
${ }^{21}$ AHU - Rio de Janeiro, cx. 70, docs. 28, 29, 40 e 65; Brasil Limites, cx. 2, doc. 125.
} 
colônia. A guerra entre as potências europeias estava na antessala do rei José. Isso queria dizer, sobre todas as mesas do secretário Sebastião e sobre todas as cabeças mais instruídas e interessadas de Portugal. A velocidade dos acontecimentos sofria aceleração. O frenesi dos fatos incomodava. A insegurança tomava conta lá e cá. Da Amazônia ao rio da Prata, a bandeira francesa cobria o mar. Do outro lado da fronteira seca de Portugal, espanhóis em carne e osso apenas aguardavam o sinal para avançar.

Os comunicados do secretário Sebastião ao governador Bobadela nos meses seguintes, 20 e 28 de abril e do 28 de maio de 1762, foram uma maneira mais que explícita de lhe delegar a responsabilidade sobre a colônia. ${ }^{22}$ Como quem diz: cuide das coisas daí que aqui a danação já é demais. Desde a longínqua Lisboa, a gente do rei José nem ninguém nada podiam. Seu maior receio era muito mais que a "praça da colônia". Seu receio era a própria toda colônia.

Muito rápido esse receio virou pesadelo. Os espanhóis tomaram aquela "praça da colônia" e precipitaram o desaparecimento de Bobadela. Em fração de semanas, o reino luso perdeu Sacramento e o secretário Sebastião, um amigo.

\section{Bobadela}

Rio de Janeiro, $1^{\circ}$ de janeiro de 1763 . Era um sábado, mais ou menos $10 \mathrm{~h}$ da manhã. Gomes Freire de Andrade fechou os olhos à tout jamais. Morreu e deixou saudade. Desaparecia o discretíssimo administrador. Fiel seguidor do reino. Rígido cumpridor de normas. Profundo conhecedor da razão de e do estado. Um homem bom, um nobre da corte. Que defendia seu império e encarnava a colônia. "Habilíssimo ministro", afirmara diversas vezes o secretário Sebastião. ${ }^{23} \mathrm{O}$ melhor governador de Portugal nas colônias, reconheceria Francisco Adolfo Varnhagen cem anos depois. ${ }^{24}$ Amplamente experimentado pela vida e pelo trabalho. Muita vez, surrado e maltratado por eles. Seu desaparecimento, completamente imprevisto, deixou um vazio imenso e produziu embaraço ainda maior. A colônia perdia uma de suas referências. Mesmo os que não conheceram Bobadela em pessoa, sentiram sua morte.

\footnotetext{
${ }^{22}$ Apud Francisco Adolfo VARNHAGEN - História Geral do Brasil, op. cit., p. 183.

${ }^{23}$ Correspondência do Governador e Capitão-general do Estado do Grão-Pará e Maranhão, Francisco Xavier de Mendonça Furtado (1751-1759). Organização de Marcos Carneiro de Mendonça. Brasília: Senado, 2004. 3 vols.

${ }^{24}$ Francisco Adolfo VARNHAGEN - História Geral do Brasil, op. cit., p. 181.
} 
Foi o caso, por exemplo, de Edward Hay, embaixador inglês em Lisboa. ${ }^{25}$ O secretário Sebastião, ainda envolvido no sentimento de perda, agiu rápido. Persuadiu o rei José a enviar imediatamente um substituto. O escolhido foi o conde da Cunha, irmão do secretário Luiz da Cunha. Sua função seria de vice-rei no Rio de Janeiro. Uma, sim, necessidade estratégica; mas mais e mais uma homenagem póstuma ao antecessor.

No dia 6 de dezembro de 1762, Bobadela recebera a notícia da perda de Sacramento. Foi participado que Vicente da Silva da Fonseca, seu enviado, capitulara. A sensação foi de desgosto profundo e desilusão sem limite. O que lhe causou depressão incontornável e incontível. ${ }^{26}$ Sacramento era muito mais que a menina de seus olhos. Protegê-la era uma necessidade. Guardá-la, um dever. Manter aquela praça do sul tinha se transformado, ao longo dos derradeiros anos desde a restauração, uma questão, mais que nunca, de honra. Ainda mais para esse homem de ancien régime absolutamente consciente de sua função naquela porção do mundo português. Foi Sacramento e, com ela, sua vontade de viver. Passou seus últimos dias completamente absorto, magoado, deprimido. Nesses mesmos dias, foi ainda acometido por "atrevida" intimidação. Recebeu, em seu palácio, uma carta anônima com duas balas dentro. ${ }^{27} \mathrm{O}$ que só fez aumentar seu desacorçoo. Nada lhe reabilitou o ânimo. Preferiu morrer. Nos seus últimos momentos, negou toda tentativa de cuidado. Fôra de amigos, fôra de médicos. ${ }^{28}$ No dia $1^{\circ}$ de janeiro, morreu. Desapareceu. Mas sua trajetória não se apagaria jamais.

De estudante de leis na antiga Universidade de Coimbra, entrou oficial de cavalaria durante a grande guerra de sucessão. Foi preso de guerra. Liberto. Feito sargento-mor. Logo em seguida, por 1733, nomeado governador e capitão-geral do Rio de Janeiro. Dois anos depois, de Minas Gerais. Em 1737, de São Paulo também. A partir de 1748, do Rio de Janeiro, de São Paulo, de Minas Gerais, de Goiás, do Mato Grosso, de Santa Catarina, de Rio Grande de São Pedro e da colônia de Sacramento. Com a chegada do rei José e do secretário Sebastião ao poder e a mise en place do tratado de limites de 1750 , foi nomeado, por patente de 1751, comissário de demarcação. Foi para o sul, para Sacramento, para as missões. Lá ficou mais de sete anos. Só voltou ao Rio de Janeiro, novamente como governador, em

\footnotetext{
${ }^{25}$ E. Hay to Earl of Egrement. Lisboa, 9 de maio de 1763. The National Archives - Londres, State Paper Foreing - Portugal, 89/58.

${ }^{26}$ BNRJ - AMU - Bahia, 6039.

${ }^{27}$ Catálogo dos capitães móres governadores, capitães generais, e vice-reis, que tem governado a capitania do Rio de Janeiro, desde a sua primeira fundação em 1565 até o presente anno de 1811 . RIHGB, tomo 21, p. 94, 1858.

${ }^{28}$ Francisco Adolfo VARNHAGEN - História Geral do Brasil, op. cit., p. 181.
} 
fevereiro de $1759 .{ }^{29}$ Mas com a obrigação moral de acompanhar os desfechos do tratado de limites.

O tratado preliminar de limites foi assinado em 13 de janeiro e ratificado no dia 26 de janeiro de 1750 em Madrid. No dia 31 de julho, seu signatário do lado português, o rei João, no alto de seus 61 anos, faleceu. Seu sucessor natural e imediato era seu filho dom José. Dom José empossou de imediato o dr. Sebastião secretário de estado do reino. O secretário Sebastião rapidamente se inteirou da gravidade e urgência das necessidades. Uma delas era a execução desse tratado. Seguiu permanentemente a negociação de detalhes em Lisboa e em Madrid. Acompanhou todas as interpretações e todas as controvérsias. Muito em breve colocaria em marcha a demarcação. Para tanto, no dia 23 de agosto de 1751, nomeou Bobadela como principal comissário régio para acompanhar a discussão com seus homólogos espanhóis in loco e administrar toda a execução e efetivação do tratado. "Probidade, zelo e inteligência" foram os principais predicados que induziram sua escolha como comissário. ${ }^{30}$

Menos de mês após a nomeação, o secretário Sebastião lhe enviou duas cartas "secretíssimas". A primeira apresentava um panorama geral dos problemas, das posições, das interpretações, das alternativas, das estratégias. A segunda resenhava e aprofundava a primeira. A tônica, sobretudo na segunda, recaiu sobre o caráter matreiro dos comissários espanhóis. Eram "dissimulados", afirmava o secretário. Portanto, toda cautela seria pouca, aconselhava. $^{31}$

No dia 19 de fevereiro de 1752, Bobadela partiu do Rio de Janeiro com destino ao sul. Foi na nau de guerra Nossa Senhora da Lampadosa. Levou larga e importante comitiva e grande comboio. Conduziu mais de dez navios com munição, mantimentos e tropas. Tudo em companhia, entre outros, do brigadeiro José Fernandes Pinto Alpoim e do chanceler Thomaz Roby de Barros Barreto. Passou raiva. Frio. Medo. Índios e jesuítas dominavam a região e dificultavam a ação. Quase nunca não eram hostis. Só não mais que os comissários do outro lado. O trabalho era lento e inglório. Difícil e desanimador. Retornou ao Rio de Janeiro mais

\footnotetext{
${ }^{29}$ Maria Fernanda BICALHO - As noções de "capitalidade" no Rio de Janeiro sob a política pombalina. In.: Ana Cristina ARAÚJO; José Luis CARDOSO; Nuno Gonçalves MONTEIRO et all. (Org.). O terremeto de 1755: impactos históricos. Lisboa: Livros Horizonte, 2007. pp. 260-1; Francisco Adolfo VARNHAGEN História Geral do Brasil, op. cit., p. 182.

${ }^{30}$ Quadro elementar das relações políticas e diplomáticas de Portugal com diversas potências do mundo desde o princípio da monarquia portuguesa até os nossos dias ordenado e composto pelo visconde de Santarém. Lisboa: Typ. da Academia Real das Sciencias, vol. 18, 1867. p. 348; Francisco Adolfo VARNHAGEN - História Geral do Brasil, op. cit., p. 159.

${ }^{31}$ Primeira Carta secretíssima de Sebastião José de Carvalho e Melo, para Gomes Freire de Andrade, para servir de suplemento às instruções que lhe foram enviadas sobre a forma de execução do Tratado Preliminar de Limites, assinado em Madrid a 13 de janeiro de 1750. Lisboa, 21 de setembro de 1751.
} 
de sete depois. Aportou no Rio de Janeiro no dia 20 de abril de 1759. Continuou acompanhando as questões do sul. Sobretudo a atuação do governador de Rio Grande de São Pedro, o general Luís Garcia de Bivar. Que, no dia 14 de fevereiro do ano seguinte, foi substituído pelo brigadeiro Vicente da Silva da Fonseca. ${ }^{32}$

Com o acirramento da guerra na Europa e da assinatura do pacto franco-espanhol, o contencioso Madrid-Lisboa foi replicado com força em Rio de Janeiro-Buenos Aires. Aliados e contra-aliados inclusive. A Inglaterra não tardou em enviar duas fragatas em favor do Rio de Janeiro e do Brasil. Isso já no ano seguinte. 1762. Lord Clive e Ambuscade. Lideradas pelo capitão John Macnamara e pelo tenente Willians Roberts. Nenhuma das duas teve êxito. Macnamara nem a própria vida salvou. Espanhóis bombardearam seu navio. Atearam fogo. E afogaram todos os sobreviventes. Contando com o próprio capitão inglês. ${ }^{33}$

Nesse contexto, a situação no sul seguia de pior a pior. Agressões eram permanentes. No dia 17 de outubro de 1762, Vicente da Silva da Fonseca comunicou a Bobadela que conseguiria defender a praça por não mais que três meses. Antes mesmo de Bobadela receber esse informe, doze embarcações, partidas do Rio de Janeiro e lideradas pelo capitão João da Costa de Athaíde, chegaram ao Rio Grande com extensa quantidade de mantimentos e munição, algum dinheiro para pagar tropas, carne, arroz, farinha, feijão, pólvora e bala. ${ }^{34}$ Nesses dias, depois de 17 ou 18 mortes, Vicente da Silva da Fonseca recuou. Assinou, no 29 de outubro, um ato de capitulação. Entregou Sacramento aos outros. ${ }^{35}$ Foi a gota d'água para Bobadela.

\footnotetext{
${ }^{32}$ Francisco Adolfo VARNHAGEN - História Geral do Brasil, op. cit., p. 183.

${ }^{33}$ Id., p. 182.

${ }^{34}$ BNRJ - AMU - Rio de Janeiro, 6039.

${ }^{35}$ Capitulação da colônia do Santíssimo Sacramento concluída a 30 de outubro de 1762. In.: Frei Cláudio da CONCEIÇÃO - Gabinete Histórico. Desde 1760 até 1762. 2. ed. Lisboa: Imprensa Nacional, tomo XV, 1881.
} 
Parte II

Insones 


\section{O secretário Sebastião}

L'histoire n'est pas une nostalgie.

Charles De Gaulle

... a virtude da
moderação não é
mais que nome.

Secretário Sebastião ${ }^{1}$

Os fatos explicarão melhor os sentimentos; os fatos são tudo.

Machado de Assis, $O$ espelho.

O secretário Sebastião foi um mito em vida. Amado e detestado. Temido e adulado. Alto, bonito, charmoso, inteligente, audacioso, perverso, covarde, autoritário, iluminado, prepotente, corajoso, pretensioso, indiferente, presunçoso, doce, vivaz, voluntarioso, amável, tímido, destemido, envolvente e outra sorte infinita de adjetivos foram utilizados para lhe descrever. Na essência, não se duvide, um homem cheio de demônios. Um gênio. Gente dessa estirpe, como nos ensina HaroldBloom, "we cannot explain, only appreciate". 2 Tinha e sempre terá razão o outro endemoninhado genial que escrevera Les Misérables quando dizia que "vrai ou faux, ce qu'on dit des hommes tient souvent autant de place dans leur vie et surtout dans leur destinée que ce qu'ils font". ${ }^{3}$ De toda maneira, os dias desse secretário de estado português marcaram profundamente a história de seu (nosso) país que, obviamente, ultrapassava as fronteiras de seu continente europeu. Análises e mais análises sobre ele - o dr. Sebastião-secretário Sebastião-conde de Oeiras-marquês de Pombal - vêm sendo feitas ato

\footnotetext{
${ }^{1}$ Discurso político sobre as vantagens que o reino de Portugal pode tirar da sua desgraça por ocasião do terremoto do $1^{\circ}$ de novembro de 1755. In.: CARTAS e outras obras selectas do Marques de Pombal. Lisboa: Typographia de Costa Sanches, tomo II, 1861. p. 98.

2 Harold BLOOM - Charlie Rose, Shakespeare Series: why Shakespeare? With Harold Bloom, Oskar Eustis, Michel Boyd. New York, CBS, 10/11/2011, 60 min.

${ }^{3}$ Victor HUGO - Les Misérables. Paris: Librairie Générale Française, 1985. p. 23.
} 
contínuo desde então, meados daquele conturbado século das luzes. Umas para louvar. Outras para demonizar. Algumas para historiar. Partindo dessas últimas ${ }^{4}$, fica a impressão de ser impossível dizer algo diferente e novo e melhor. O objetivo do que se segue visa apenas sumarizar alguns momentos decisivos da administração do nobre secretário durante seus primeiros 13, 14 anos de gestão. Especialmente dar uma notícia do tratado de limites, o terremoto, a guerra dos sete anos. Justo de 1750-1763.

Logo se entenderá a utilidade dessa manobra.

\section{Depois das Tordesilhas}

No dia 26 de janeiro de 1750, o rei João de Portugal ratificou o tratado de Madrid. Treze dias depois, no dia 8 de fevereiro, rei Fernando da Espanha fez o mesmo. O acordo foi produto de longo trabalho de reflexão e engajamento. Punha em conformes os limites territoriais ibéricos. Teve como protagonista inconteste o advogado e economista santista Alexandre de Gusmão. Reconhecido estrategista do império português. Bem-quisto de seu soberano e de influentes na corte e em Lisboa. O texto, assinado previamente no dia 13 de janeiro pelo visconde de Villa Nova da Cerveira e pelo ministro José de Carvajal e Lancastre, respectivos plenipotenciários de Portugal e Espanha, foi passo de importância na resolução do contencioso. A maior ambição do acordo foi claramente revisitar todos os tratados

\footnotetext{
${ }^{4}$ Ver, dentro outros, João Lúcio de AZEVEDO - Épocas de Portugal Económico. Esboço de História. Lisboa: Clássica Editora, 1988. João Lúcio de AZEVEDO - O Marquês de Pombal e a sua Época. Lisboa: Clássica, 1990. Francisco BETTENCOURT \& Kirti CHAUDHURI - História da Expansão Portuguesa. Lisboa: Círculo de Leitores, 1998. 5 vols. João Pedro FERRO - A População Portuguesa no Final do Antigo Regime (1750-1815). Lisboa: Presença, 1995. José MATTOSO (dir.) - História de Portugal. Lisboa: Círculo de Leitores, vol. 4, 1993. Luís A. de Oliveira RAMOS - Sob o Signo das Luzes. Lisboa: INCM, 1987. José Vicente SERRÃ̃ - Do Antigo Regime ao Liberalismo. 1750-1850. Lisboa: Vega, 1989. Camilo CASTELO BRANCO - Perfil do Marquês de Pombal. Porto, Porto Editora, 1962. Hernâni CIDADE - O marquês de Pombal. O Homem e a Obra na Metrópole e no Ultramar. Lisboa: Agência Geral do Ultramar, 1963. Clara DIAS - Marquês de Pombal. Porto: Asa, 1993. Jorge Borges de MACEDO - O Marquês de Pombal. 16991782. Lisboa: Biblioteca Nacional, 1982. MINISTÉRIO DA CULTURA E COORDENAÇÃO CIENTÍFICA Marquês de Pombal: Catálogo Bibliográfico e Iconográfico, edição para a comemoração do $2{ }^{\circ}$ Centenário da morte de Marquês de Pombal. Lisboa: Biblioteca Nacional, 1982. Maria Helena Carvalho dos SANTOS Pombal Revisitado. Lisboa: Estampa, 1984. Francisco José Calazans FALCON - A Época Pombalina. Política Económica e Monarquia Ilustrada. São Paulo: Ática, 1982. Luís José BAIARDO - O Marquês de Pombal, Sebastião José de Carvalho e Melo, ou o Terramoto de 1755. Lisboa: Tipografia António José da Costa, 1839. CÂMARA MUNICIPAL DE LISBOA - Exposição Comemorativa do Terramoto de 1755. Catálogo. Exposição realizada de 1 a 15 de Novembro de 1934, no Pavilhão de festas do Parque Eduardo VII, na cidade de Lisboa. Lisboa: Câmara Municipal, 1934. FUNDAÇÃO CALOUSTE GULBENKIAN - Cartografia Portuguesa do Marquês de Pombal a Filipe Folque. 1750-1900: o património histórico e cartográfico do Instituto Geográfico e Cadastral. Lisboa, 1982. Visconde de CARNAXIDE - O Brasil na Administração Pombalina: Economia e Política Externa. São Paulo: Editora Nacional, 1940. António CARREIRA - As Companhias Pombalinas de Grão-Pará e Maranhão e Pernambuco e Paraíba. 2. ed. Lisboa: Editorial Presença, 1983.
} 
precedentes. Seu primeiro ato foi xeque-matear o tratado de Tordesilhas de 1494. Em seguida, reler o tratado de Lisboa de 1661. E, por fim, inutilizar o tratado d'Utrecht de 1715. Tudo para chegar o fundamental: os limites coloniais. Especialmente americano-meridionais. Em uma palavra: Sacramento. Vale lembrar que o texto ratificado tinha 26 artigos. O primeiro, mais abstrato, refutava todos os tratados precedentes que demarcavam legalmente territórios dos dois reinos nas Américas e na Ásia. A menção à Ásia não foi sem propósito. Determinara-se, logo no segundo artigo, que as Filipinas e ilhas adjacentes seriam doravante de domínio espanhol. O contraponto foi dar posse ao Portugal de tudo que cobria do rio Maranhão, Amazonas e distrito do Mato Grosso. Do artigo $4^{\circ}$ em diante, o único assunto em questão foi o sul da América do sul. Espanha cederia ao Portugal tudo que circundasse a banda oriental do rio Uruguai e setentrional do rio Ybicui. Portugal abdicaria da colônia de Sacramento. A execução de tudo isso dependeria da inspeção de comissários de cada um dos reinos. Em claro, esses pontos foram os primazes do tratado. Evidentemente houve detalhes. Exemplos. Proibição do contrabando na área. Proibição da feitura de fortificações na área. Paz entre os vassalos, portugueses e espanhóis e de nações amigas, em caso de guerra entre as coroas na região. ${ }^{5}$

No dia 31 de julho daquele 1750, o rei João desapareceu. Tinha 61 anos. Nem velho, nem moço. O vácuo de poder abriu cancha para sucessão. Dom José ascendeu monarca. Em seguida, nomeou o dr. Sebastião José de Carvalho e Mello secretário de estado. O tratado de limites foi de seus primeiros grandes trabalhos.

\footnotetext{
5 Jaime CORTESÃO - Alexandre de Gusmão e o Tratado de Madrid. Rio de Janeiro: Instituto Rio Branco, 1950. 9 vols. Quadro elementar das relações políticas e diplomáticas de Portugal com diversas potências do mundo desde o princípio da monarquia portuguesa até os nossos dias ordenado e composto pelo visconde de Santarém. Lisboa: Typ. da Academia Real das Sciencias, tomo 2, 1864. pp. 232-244.
} 


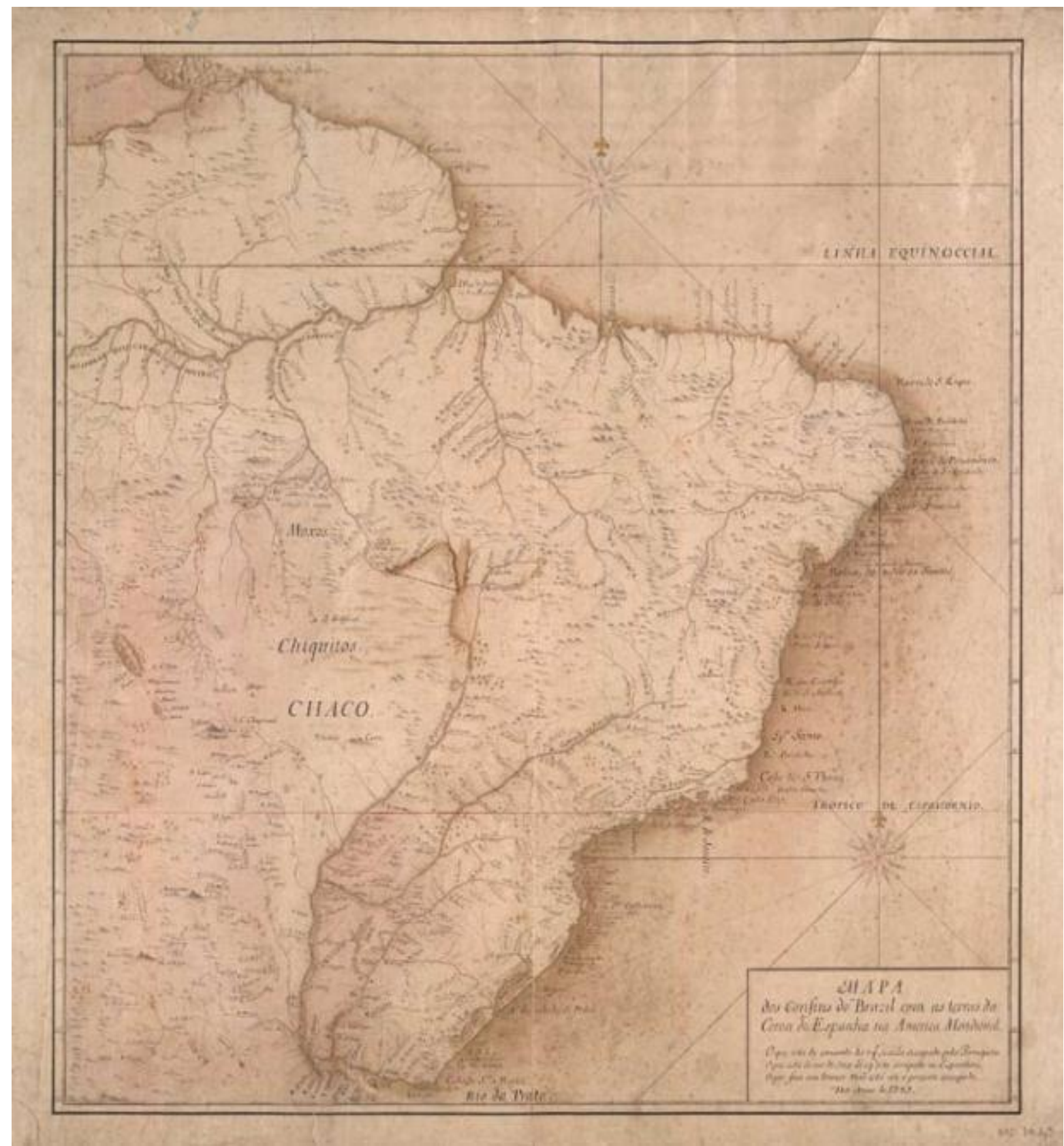

Carta das cortes, $1749^{6}$

Alexandre de Gusmão e o tratado de limites eram sinônimos do lado português. O rei José, para reconhecer os importantes serviços prestados por esse brasílico, o designou à secretaria de estado dos negócios da marinha e dos domínios ultramarinos. O secretário Sebastião gostou nada. Em princípio, não considerava Gusmão tudo aquilo que corria de boca em boca. Por fim, não o queria em seu caminho. Questão de nervos e personalidade. Ambos possuíam duro carácter emergido de fortes convicções. Ambos eram gigantes. Em tamanho e

\footnotetext{
${ }^{6}$ Autoria desconhecida Mapa dos confins do Brasil com as terras da Coroa da Espanha na América Meridional, 1749. In.: Question des limites du Brésil et de la Guyane Anglaise soumise a l'arbitrage de S. M. Le Roi D'Italie. Paris: Ducourtioux et Huillard, 1903.
} 
em certezas. A corte ficou pequena. O conflito, que se presumia sem fim, não perdurou por muito tempo. Gusmão morreu em $1753 .^{7}$

A impressão do dr. Sebastião sobre o tratado, bem ou mal, foi grafada em suas Cartas secretíssimas. ${ }^{8}$ Ao todo duas. Ambas do dia 21 de setembro de 1751. Ambas para o governador Bobadela, comissário responsável pelas demarcações do sul. De modo geral, o nobre secretário Sebastião acreditava que era definitivamente perigoso tratar com espanhóis. Eles eram amplamente capciosos. Perniciosos. E suas propostas para a América meridional eram, francamente, inaceitáveis. Mas, tratado assinado, cumpria cumprir. Seria longo e árduo esse cumprimento. Embora uma primeira "vitória" tenha ocorrido em 1753 depois do reconhecimento, por convenção, entre Portugal e Espanha do assunto Sacramento. ${ }^{9}$

O sismo

Lisboa, novembro de 1755. Sábado, $1^{\circ}$ do mês. Dia de festa. Festa de todos os santos. Igrejas cheias. Ruas movimentadas. Alegria. Euforia. Devoção. Estação, outono. Temperatura, $14^{\circ}$ C. Vento de outono. Frescor de outono. Manhã de outono. 9h40, 9h45. O chão tremeu. Mais que 6, menos que 7 minutos. Foi sincopado. Vário em intensidade. Nenhum grande edifício suportou. Igrejas, prédios, sobrados. Tudo desabou. Tudo foi a terra. Restou de muito só poeira. Quem em pessoa restou, correu. Gritou. Clamou. Chorou. Indagou. Senhor, senhor; por que me abandonaste?! Nada adiantou. A terra voltou a tremer. Menos forte. Mas moveu o chão. O mar - e o rio - desapareceu. A maioria nem percebeu. Continuou a correr. Sem destino. Sem sentido. Pensando em nada. Entendendo, também, por certo, nada. Fugindo. Sós. Com medo. Sem chão. Muito em breve, com água. As águas do Tejo voltaram. Não em farsa. Vieram aumentar a tragédia. Quem, na espera de se salvar, buscara abrigo em suas margens, foi engolido. Sem piedade. Com voracidade integral. As

\footnotetext{
${ }^{7}$ Marcelo CAETANO - Do conselho ultramarino ao conselho do império. Portugal: Divisão de publicações e Biblioteca Agência das Colônias, 1943. pp. 33-4. Quadro elementar das relações políticas e diplomáticas de Portugal com diversas potências do mundo desde o princípio da monarquia portuguesa até os nossos dias ordenado e composto pelo visconde de Santarém. Lisboa: Typ. da Academia Real das Sciencias, tomo 8, 1864. p. 348.

${ }^{8}$ Primeira Carta secretíssima de Sebastião José de Carvalho e Melo, para Gomes Freire de Andrade, para servir de suplemento às instruções que lhe foram enviadas sobre a forma de execução do Tratado Preliminar de Limites, assinado em Madrid a 13 de janeiro de 1750. Lisboa, 21 de setembro de 1751. Segunda Carta secretíssima de Sebastião José de Carvalho e Melo para Gomes Freire de Andrade, sobre os oficiais militares que se lhes enviaram, assim, nacionais, como estrangeiros, com motivo da execução do Tratado de Limites. Lisboa, 21 de setembro de 1751.

${ }^{9}$ Quadro elementar, op. cit., tomo 8, p. 245.
} 
águas se fizeram ondas. Ondas de morte. Um maremoto. Que lavou o pó. Destroçou mais edifícios. Levou mais gente. Mais esperança. Mais fé. Aquele $1^{\circ}$ de novembro era um dia de fé. Ardente fé. Que, no adeus das águas, ardeu nas chamas. O fogo não demorou a começar. Nada num raio de uma légua não queimou. O palácio do marquês de Louriçal. A igreja de São Domingos. O recolhimento do Castelo. O bairro da Ribeira. Da rua Nova. Do Rocio. Dos Romulares. Do Limoeiro. De Alfama. O dito bairro Alto. Quase nada sobrou. As casas de madeira alimentaram fogueiras por dias e dias. 5, 6 dias. Sem trégua. Os viventes foram reduzidos em sua fé. Duvidaram de Deus. Do rei. Da vida. Ficaram esgualepados. Perdidos. Penados. Desolados. Penando. Locais e não locais. Cada qual à sua não-maneira construía o mosaico da danação. Desgraça eternal. Desgraça terrena. Desgraça total. Somada a rapinagem. Bandoleiros e marginais iniciaram roubos e furtos. Pequenos e grandes. Canalhas iniciaram a violar donzelas e damas em geral. Miséria humana. Nada mais. Nem menos. Miséria. Quem sobreviveu fez de tudo para fugir. Ora invadindo outras cidades. Ora penetrando os jardins de Belém na procura de abrigo nos braços do rei. Belém - casa de campo, casa real -, por milagre, não fôra afetada. Quem não saiu de Lisboa, foi tirado. Em algum momento, alguém se lembrou da existência de uma casa de pólvora no meio da cidade. O medo de mais desventura conduziu a evacuação. O rei José mandou construir cabanas, barracos, vivendas por todos os jardins reais. Viraram jardim de refugiados. Refugiados climáticos. Os primeiros na história. Na tormenta, não houve escolhas prioritárias. Com o passar dos dias, se preferenciou ordens religiosas e a fidalguia. O rei mandou socorrer. Cuidar. Vestir. Dar de comer. Utilizou medidas excepcionais, sendo que o caso era, em forma e conteúdo, agudamente excepcional. ${ }^{10}$

O rei José teve imenso trabalho. Ao menos simbólico. Teve medo. Dificuldades. Momentos de desespero, momentos de desilusão.

Fogo, maremotos e terremotos consumiram Lisboa. Mais da metade da cidade, com o que nela continha, se perdeu para nunca mais. Perdas inestimáveis. Pessoas: entre 10 e 40 mil. Preciosidades: joias, armações, vidros, vitrais, cristais, porcelanas, ouros, pratas, sedas, panos;

\footnotetext{
10 Memórias das principais providências que se derão no terremoto que padeceo a Corte de Lisboa no ano de 1755, ordenadas, e oferecidas à Majestade Fidelíssima de El Rey D. Joseph I, nosso senhor por Amador Patrício de Lisboa. Lisboa, 1758. Estragos do Terremoto. Vatecinio de felicidades. Sobre os habitadores da nobilíssima Villa de Setuval na jusfificada aflição em que se virão no primeiro de novembro de 1755. Oferecido ao Ilmo. Senhor D. Antonio Luiz Caetano de Souza Marques das Minas, conselheiro de guerra, Gentil-Homem da Camara de sua Majestade Fidelíssima. Por Francisco de Santo Alberto. Lisboa, 1757. Frei Cláudio da CONCEIÇÃO - Gabinete Histórico. Desde janeiro de 1755 até dezembro de 1758. 2. ed. Lisboa: Imprensa Nacional, tomo XII, 1881. João Duarte FONSECA - 1755, o Terramoto de Lisboa. Lisboa: Argumentum, 2004.
} 
obras de arte; livros; igrejas. 35 das 40 igrejas. Diversas importantes bibliotecas e livrarias foram tragadas. Livrarias e bibliotecas de franceses, italianos, espanhóis. A biblioteca real, largamente aumentada pelo rei João. As bibliotecas do marquês de Louriçal, do convento de São Domingo, do Carmo, de São Francisco, de Trindade, da Boa hora. Das aproximadas 20 mil casas, apenas 3 mil seguiram habitáveis. ${ }^{11}$ Desolação real. Que só fez aumentar com os dias. O sismo não castigara apenas em Lisboa. Todo o Portugal sofria. Mafra, Cascaes, Cintra, Ericeira, Ribaltejo, Alemquer, a maior vila de Portugal que era Santarém, Tejo, Palmela, Beira, Alentejo.

Muito problema. Muito trabalho. Muita crise. Muita necessidade de decisão e gestão. Tudo, de fato, ficou a cargo do secretário Sebastião.

Não se sabia ao certo se fôra punição dos céus ou da terra. Por desencargo, na primeira oportunidade, foi agendada uma procissão. No dia 13 de novembro, os lusos foram convocados a, descalços, implorar a misericórdia de Deus. Foi uma estratégia religiosa para retomar o moral. Antes e depois desse cortejo, muito se fez para conferir socorro, alívio, segurança. Milhares de corpos espalhados pelas ruas foram sepultados. Muitos outros já não eram mais que carne podre. Doenças de indizíveis tipos eram previstas. Mesmo pestes. Muitos cogitavam até inclusive uma nova negra. Além disso, o povo tinha fome. Por isso, praticamente todos os celeiros foram abertos. Tudo que se tinha de farinha e víveres foi distribuído. A fome, real antes mesmo do sismo, passou de endêmica a pandêmica. A partir do 24 de novembro, dinheiro também começou a ser distribuído. Os ladrões e marginais identificados foram exemplarmente punidos. Muitos foram enforcados. Outros muitos foram lançados ao mar. Serviços de enfermagem foram, como nunca, expandidos. Muitos feridos e doentes foram encaminhados a enfermarias. Inclusive as reais. Militares espalhados pelo reino foram instados a Lisboa. Moradores, desaparecidos de Lisboa por medo, foram encorajados a retornar. Retomar a vida e reconstruir a normalidade. Alojamentos e casas foram sendo rebatidas. O setor de construção civil recebeu incentivo. Madeira e cal foram subvencionadas. Ofícios e atividades divinos foram retomando seus lugares. Religiosos dispersos foram sendo reagrupados. Por fim, a reedificação das cidades. A primeira mesura sobre o assunto foi iniciada no dia 29 de novembro. Era preciso avaliar o estrago. Catalogar o desboque. Medir praças, ruas, casas, edifícios. Retirar entulhos. Limpar, em especial e mais urgentemente, os bairros, antes, nobres. Rocio, rua Nova etc. Mais de trezentas pessoas - metade soldados,

\footnotetext{
${ }^{11}$ Kenneth MAXWELL - Marquês de Pombal. Paradoxo do Iluminismo. 2. ed. São Paulo: Paz e Terra, 1996. pp. 23-4. Frei Cláudio da CONCEIÇÃO - Gabinete Histórico, op. cit., tomo XII, p. 54.
} 
metade civis - trabalharam nisso durante mais de ano. Apenas em maio de 1758, foram abertos editais para conferir direitos públicos e particulares para a reedificação das cidades; primeiro da Lisboa. ${ }^{12}$

\section{Sismo do sismo}

Constrange falar do terremoto de 1755. Improvável e impossível não repisar pasto pisado. Coevos dele e contemporâneos nossos foram e são, somos, fascinados pelo incidente. Dos deles, Voltaire, Kant, Rousseau, Casanova, Gabriel Malagrida, um tal Francisco Xavier de Oliveira e o próprio secretário Sebastião. ${ }^{13}$ Dos nossos, o conjunto de autores de $O$ terremeto de $1755^{14}$ dá uma noção da atualização e da atualidade do tema e do debate. Faz um balanço.

O assunto virou catarata. Garganta do diabo. Sujeito inesgotável. Sobretudo porque não afetou apenas Lisboa e Portugal. Molestou muitos reinos e estados no $1^{\circ}$ de novembro e nos dias e meses seguintes. No mesmo dia $1^{\circ}, 20$ minutos depois do primeiro estrondo na capital lusa, abalou Madrid, Estouro e Sevilha na Espanha. Pouco mais ou menos, Bordeaux e Strasbourg na França. Simultaneamente, a Lombardia na Itália. Pelas 12h, Haya e Amsterdam nos Países Baixos. Pouco mais ou menos, Treplin, região metropolitana de Berlim. No mesmo momento, diversas localidades em Dinamarca, Suécia, Noruega. E também Açores e Marrocos. Tarde na Europa, manhã nas Américas, vibrou Barbados e Nova Inglaterra. ${ }^{15}$

De toda maneira, português que viu a terra escapar de seus pés não recebeu, nem receberia, notícia de outros sismos como consolo. Homens de ação da época, muito menos. Esse pragmatismo, necessário e oportuno, concernia a todos os envolvidos com coisas de Portugal. Não por acaso, o rei George da Inglaterra, enviou importante socorro. Em dinheiro, comida, gente. 270 mil cruzados. 140 mil em dinheiro espanhol. 200 mil alqueires de farinha.

\footnotetext{
${ }^{12}$ Frei Cláudio da CONCEIÇÃO - Gabinete Histórico, op. cit., tomo XII, pp. 134-9.

${ }^{13}$ O Juízo da verdadeira causa do terremoto... e o sacrifício simbólico do Pe. Gabriel Malagrida; seguido do fac-simíle da edição princeps desta obra (Lisboa, oficina de Manuel Soares, 1756) e outros documentos sobre a circulação da obra e punição deste jesuíta / direcção e edição de Manuel Cadafaz de Matos. Lisboa: Távola Redonda, 2008. Francisco Xavier de OLIVEIRA - Discurso patético sobre as calamidades presentes sucedidas em Portugal: seguimento do discurso patético. Lisboa: Frenesi, 2004. VOLTAIRE - Candide ou l'optimisme. Paris, 1759. Immanuel KANT - Escritos sobre o terramoto de Lisboa. Trad. Benedith Bettencourt. Coimbra: Almedina, 2005.

${ }^{14}$ Ana Cristina ARAÚJO; José Luis CARDOSO; Nuno Gonçalves MONTEIRO et all (Org.). O terremoto de 1755: impactos históricos. Lisboa: Livros Horizonte, 2007.

${ }^{15}$ Frei Cláudio da CONCEIÇÃO - Gabinete Histórico, op. cit., tomo 12, pp. 146-51.
} 
200 mil alqueires de trigo. 6 mil barris de carne salgada. 4 mil barris de manteiga. 11 mil barris de arroz. 15 mil sacas de bolacha. Milhares de sapatos. Tudo em seis navios de guerra repletos de soldados e civis para auxiliar os portugueses no que de precisão. A dimensão dessa ajuda surpreendeu inclusive o embaixador francês em Lisboa que participou com espanto todos esses detalhes aos seus superiores em Versailles. ${ }^{16}$

No caso do Brasil, ajudar era mais que cooperação. Era obrigação. Imposição intrínseca ao pacto: Portugal-Brasil. Intrínseco ao regime. A gestão desse suposto produziu dificuldades na colônia. Conflitos e tensões se multiplicaram, sobretudo, nas principais vilas. Rio de Janeiro e Bahia. ${ }^{17}$ Havia conflitos e tensões em demasia sobre o birô do secretário Sebastião.

Em 1783, mais de um ano da morte do dr. Sebastião, se fez publicar pela livraria do erudito desembargador da Gamboa o autógrafo Discurso político sobre as vantagens que o reino de Portugal pode tirar da sua desgraça por ocasião do terremoto do $1^{o}$ de novembro de 1755. O discurso foi atribuído ao secretário Sebastião e não existe nada que conteste sua autoria. $^{18}$

O enunciado guarda algum suspense. Os primeiros tópicos também. A mensagem vai aparecendo em crescendo. A maior vantagem da desgraça que foi o terremoto de Lisboa poderia ser a possibilidade de se suplantar a desgraça que era o julgo imposto pela Inglaterra. Com decoro e retórica absolutamente irreprocháveis, o secretário Sebastião construiu um argumento que seduz pela forma e convence pelo conteúdo. Com o fim da união ibérica, Portugal legou sua segurança e liberdade à Inglaterra. O objetivo era fugir do jugo espanhol. A monarquia lusa queria; a britânica estendeu a mão. Ora para socorrer, ora para oprimir. Queixava o nobre secretário. Contextualizando o dia anterior ao terremoto, descrevia os pontos principais de sua crítica aos malefícios da intromissão inglesa. Agricultura: ingleses destruíram a agricultura portuguesa. Desvalorizaram suas terras. Incentivaram êxodos. Ocuparam territórios. Com isso, impuseram dependência à boca. Comércio: ingleses, depois

\footnotetext{
${ }^{16}$ Quadro elementar, op. cit., vol. 18, p. 363.

${ }^{17}$ Para mais detalhes, ver Carolina Chaves FERRO - Terremoto em Lisboa, tremor na Bahia. Um protesto contra o donativo para a reconstrução de Lisboa. Niterói, 2009. (Dissertação apresentada à Universidade Federal Fluminense)

${ }^{18}$ Discurso político sobre as vantagens que o reino de Portugal pode tirar da sua desgraça por ocasião do terremoto do $1^{o}$ de novembro de 1755. In.: CARTAS e outras obras selectas do Marques de Pombal. Lisboa: Typographia de Costa Sanches, tomo II, 1861. pp. 97-187.
} 
das terras, ocuparam o comércio. "Eram ao mesmo tempo patrões e feitores dos víveres." Nem o comércio do Brasil era poupado. "Não havia coisa portuguesa em seu comércio mais que o nome". Indústria: ingleses neutralizaram o florescimento industrial português a partir de tratados de cooperação. Recebia vinhos e impunha seus panos. Política: os ingleses neutralizaram toda autonomia portuguesa para tomar decisões. Impôs um severo constrangimento. Impediu sua entrada em guerras pela Europa. Metalismo: ingleses estimularam esforços para exploração de minas de ouro em detrimento de outras atividades. Ação que concorreu para a aceleração o enfraquecimento e desfalecimento da economia lusa. Mesmo os negros que tralhavam nas minas do Brasil eram vestidos pelos ingleses.

O pior dessas múltiplas dependências, imposições e ilusões era o estado de pobreza gerado pela corrupção. Portugal estava carcomido pela desgraça da corrupção. O rei era rico; o povo, pobre. A desgraça do terremoto, sempre na visão do secretário Sebastião, poderia forjar a mudança.

\section{Guerras do Secretário}

O Discurso político veio a público aftermath. Quando o dr. Sebastião e o rei José não estavam mais entre os vivos. Mas seu diagnóstico não fôra em nada extravagante. Nada diferente do que observadores ponderavam recorrentemente. O conde de Merle, enviado da França em Lisboa no pós-terremoto, relatara, com mais fortes cores, a daninha relação lusobritânica para com Portugal. Vindo do secretário geral do rei José, independente de suposto déjà $v u$ da avaliação, o diagnóstico tem relevo diferente. O secretário Sebastião queria a mudança. Queria fugir desse subjugo. Não foi dessa vez. Menos de ano após o sismo de Lisboa de 1755, outro sismo, agora político, ocasionado pelo acirramento de rivalidades entre potências europeias, tomou tempo e esforço e energia desse homem maior do estado português. A guerra dos sete anos, capitaneada pelas principais lideranças da Europa de então que eram Inglaterra e França, redesenhou a carta de praticamente todo o Ocidente. ${ }^{19}$

\footnotetext{
${ }^{19}$ Fred ANDERSON - Crucible of War: the seven years' war and the fate of empire in British North America, 1754-1766. London: Faber and Faber, 2001. Fred ANDERSON \& Andrew CAYTON - The Dominion of War: Empire and Liberty in North America 1500-2000. New York: Penguin Books, 2005. Jeremy BLACK - Pitt the Elder. Cambridge: Cambridge University Press, 1992. Alice Clare CARTER - The Dutch Republic in Europe in the Seven Years War. London: MacMillan, 1971. Christopher HIBBERT - George III: A Personal History. London: Penguin, 1999. Frank MCLYNN - 1759: The Year Britain Became Master of the World. London: Pimlico, 2005. N. A. M RODGER - Command of the Ocean: A Naval History of Britain, 1649-1815. London:
} 
O século XVII reorientou o lugar das potências europeias. No pós-1660, guerra e diplomacia impuseram a ascensão e declínio de estados por toda a Europa. França, Inglaterra, Rússia, império de Habsburg e Prússia se afirmaram na dianteira dos fatos. Espanha, império ottomano, Países Baixos, Suécia passaram a segundo time. Polônia se tornou absolutamente desimportante. Quase desprezível. Essa reordenação de forças foi à custa, sobretudo, de geografia e finanças, história e estratégias, diplomacia e guerras. Ou, para seguir os termos surrados, mas ainda eficientes de The rise and fall of the great powers, novas riquezas passaram a necessitar de novos aparatos militares como proteção, novos aparatos militares passaram a necessitar de novas riquezas para lhes sustentar.

A França, por exemplo, incitou ao menos quatro grandes guerras por territórios e poder entre 1689 a 1763 . O objetivo, na maior das vezes, foi dominar o centro e o oeste da Europa. Esse campo minado sempre colidiu com aliançados ou subordinados à Inglaterra e/ou ainda simplesmente contrários à França. Essa “justificável” obsessão por guerras conferiu certo pioneirismo aos franceses no quesito organização militar. Sob o reinado do rei Louis, ministros visionários como Colbert e Louvois foram os primeiros a impor ao estado o monopólio do poder militar a partir da criação da secretaria de guerra. Isso, somado a avanços tecnológicos, conferiu imenso salto de qualidade à gestão de guerras. Inglaterra e Rússia seguiram caminhos similares de modernização. Diferente apenas em foco. Britânicos focaram nos mares. Russos, em terra. Os primeiros se transformaram em potência marítima definitiva. Os outros, os russos, num dos maiores exércitos terrestres da época. Portugal e Espanha tiveram suas forças atrofiadas conjunta e progressivamente. ${ }^{20}$

\begin{tabular}{|l|c|c|c|c|c|c|}
\hline \multicolumn{7}{|c|}{ Contingentes militares } \\
\hline & 1690 & 1710 & $1756-1760$ & 1778 & 1789 & $1812-1814$ \\
\hline Inglaterra & 70.000 & 75.000 & 200.000 & 40.000 & 250.000 & - \\
\hline França & 400.000 & 350.000 & 330.000 & 170.00 & 180.000 & 600.000 \\
\hline Império Habsburg & 50.000 & 100.000 & 200.000 & 200.000 & 300.000 & 250.000 \\
\hline Prússia & 30.000 & 39.000 & 195.000 & 160.000 & 190.000 & 270.000 \\
\hline Rússia & 170.000 & 220.000 & 330.000 & - & 300.000 & 500.000 \\
\hline Espanha & - & 30.000 & - & - & 50.000 & - \\
\hline
\end{tabular}

Fonte: Kennedy, 1987, p. 183.

Penguin, 2006. Brendan SIMMS - Three Victories and a Defeat: The Rise and Fall of the First British Empire. London: Penguin, 2008.

${ }^{20}$ Paul KENNEDY - The Rise and Fall of the Great Powers. Economic Change and Military Conflict from 1500 to 2000. New York: Random House, 1987. p. 147-77. H. T. DICKINSON - A companion to eigheteen-century Britain/Blackwell Companions to British History. London: Wiley-Blackwel, 2002. 
A guerra dos sete anos, para retomar o fio, foi momento decisivo do concerto europeu. 1740, para não retroceder demais, deu o start. Primeiro, a morte do imperador da Áustria, Charles VI, sucedido por Maria-Thérèse. Em seguida, no inverno de 1740-1, a anexação da Silésia pelas tropas prussas lideradas por Frederico II. A França apoiou incondicionalmente os avanços de Frederico II com intuito de minar a herdeira Habsburg. A Inglaterra veio em socorro de Maria-Thérèse e reatou a velha aliança anglo-austríaca. Tropas inglesas entraram no conflito e ajudaram os austríacos a expulsar prussos e franceses dos territórios ocupados. Como revanche, franceses se dirigiram aos Países Baixos. Em resposta, os ingleses bloquearam rotas comerciais marítimas de França e seus parceiros. Isso implicou ações que cobriram o espaço europeu e ultrapassaram aos domínios coloniais. Os custos dessas operações se traduziram em aumento de impostos. Civis franceses e britânicos protestaram. A impopularidade do conflito foi resolvida pelo tratado de Aix-la-Chapelle de 1748. Que forjou partida em retirada para ambos e o amainamento de todos os humores. Entretanto, MariaThérèse jamais esqueceria a audácia dos prussos. O desejo de vingança seguiu latente. Do lado dos franceses, idem. A França refletia, sem cesse, sobre como vencer os britânicos no continente e nas colônias. A tensão nas Américas se intensificava proporcionalmente. Muito especialmente, ao norte. Em 1755, a perspectiva de novo conflito franco-inglês se materializou. Dispositivos de forças terrestres e marítimas se puseram em alerta. Espanha se pôs neutra. Ao Portugal foi imposta a neutralidade. Prússia colocou mais de 150 mil soldados em teatros de guerra. Áustria, 200 mil. Rússia, muito mais que 300 mil. No ano seguinte, 1756, a França, lançando mão de seu arranjo diplomático, rebaralhou seu núcleo de alianças. Borrou suas animosidades com os Habsburg e avivou boa relação com a Áustria. Em adição, com a Rússia. Londres, em outra via, se aliou à Berlim e a Frederico II. A guerra recomeçava. E, novamente, de modo transcontinental. Ingleses e prussos mobilizaram todos os seus aliados. Seus domínios e habilidades militar e naval aglutinados, rapidamente, deram prova de superioridade. Sobriedade também.

\begin{tabular}{|l|c|c|c|c|c|c|}
\hline \multicolumn{7}{|c|}{ Navios de guerra } \\
\hline & 1689 & 1739 & 1756 & 1779 & 1790 & 1815 \\
\hline Inglaterra & 100 & 124 & 105 & 90 & 195 & 214 \\
\hline Dinamarca & 29 & - & - & - & 38 & - \\
\hline França & 120 & 50 & 70 & 63 & 81 & 80 \\
\hline Rússia & - & 30 & - & 40 & 67 & 40 \\
\hline Espanha & - & 34 & 48 & 72 & 25 & - \\
\hline
\end{tabular}

Fonte: Kennedy, 1987, p. 183. 
A Royal navy passou a manchar mares e oceanos. Do Mediterrâneo ao Atlântico. Do Pacífico ao Índico. De Cartagena a Lagos. Do Rio de Janeiro e Buenos Aires a Quiberon a Toulon. Essa mão gigante e bem visível sobre as águas isolou França e companhia. Canadá e Antilhas ficaram sem apoio metropolitano. Não por desleixo, e muito pelo contrário, em 1759, colônias francesas recaíram sob o mando inglês. Por terra, vitórias anglo-germânicas progrediam. Em 1762, a Espanha entrou na guerra. Em consequência, perdeu colônias nas Antilhas e nas Filipinas. O escasseamento de recursos financeiros e humanos - a Prússia, para ficar apenas com um número, perdera 60 mil soldados apenas em 1759 - impulsionou o fim da guerra. A Inglaterra, como previsível, saiu vitoriosa. Mas não demoraria a perder outra guerra: os EUA. ${ }^{21}$ Mas essa seria outra história.

O amor do secretário Sebastião por seu irmão Francisco Xavier de Mendonça Furtado era importante. Admiração quase obsessiva e respeito incondicional. Ambos eram ligados pelo sangue e pelo trabalho. Quando o Atlântico os separou, sua correspondência privada se multiplicou. De 1751 a 1759, Mendonça Furtado esteve governador e capitão geral do estado do Grão-Pará e do Maranhão. O conjunto de suas cartas - oportunamente organizadas por Marcos Carneiro de Mendonça ${ }^{22}$ - revela homens sensíveis, agudos, discretos. Ambos leais ao seu tempo e ao decoro do régime. Daí a inconfundível riqueza de forma e conteúdo de sua correspondência. Detalhes de vida privada eram somados a análise de conjuntura. Sempre numa demonstração natural de erudição plena. No dia 22 de novembro de 1755, desde o Arraial de Muriuá, o dr. Sebastião endereçou mais uma carta ao irmão. A primeira depois do sismo. O sismo, em si, não fôra mencionado. Somente as "moléstias" que o estresse do póssismo estavam lhe causando. Mas o contencioso gerido pelo governador Bobadela, esse sim, foi mencionado. O que não era de estranhar. Como também não foi estranha a menção do secretário à situação europeia. Foi das primeiras proposições do secretário de estado sobre o conflito iminente entre França e Inglaterra e todo mundo no mundo. Escreveu o dr. Sebastião: “a guerra dos franceses com os ingleses, como nos deixam, não nos prejudicará e, conquanto

\footnotetext{
${ }^{21}$ Id., pp. 200-5.

${ }^{22}$ Correspondência do Governador e Capitão-general do Estado do Grão-Pará e Maranhão, Francisco Xavier de Mendonça Furtado (1751-1759). Organização de Marcos Carneiro de Mendonça. Brasília: Senado, 2004. 3 vols.
} 
se quebrassem as cabeças uns aos outros, espero em Deus que nos conservemos em forma que teremos daquela discórdia as felicidades que a paz traz consigo". ${ }^{23}$

Veio a paz. Mesmo que relativa. Mas depois da guerra. Guerra que, inevitavelmente, implicou Portugal.

Oficializada a guerra, em 1756, das primeiras decisões do secretário Sebastião foi mandar trazer Luiz da Cunha, que servia como ministro de Portugal em Londres. Ele seria, acreditava e apostava o secretário Sebastião, indispensável em Lisboa.

Homem de experiência, confiança e competência reconhecidas, Luiz da Cunha foi tornado ministro geral dos negócios estrangeiros de Portugal. Essa decisão foi reação à preocupação da cúpula do rei José com a guerra da aliada Inglaterra que tornaria os inimigos ingleses automaticamente inimigos de Portugal. ${ }^{24}$ Agressões vindas de França e Espanha se tornaram iminentes. Ambos vizinhos, indesejados e inevitáveis. Desconfianças e manipulações se multiplicariam. Hostilidades, também. Versailles nem Madrid eram afeiçoados ao pacto luso-britânico. Espanhóis e franceses não eram necessariamente bemquistos em terras lusitanas. Muito menos portugueses no contraponto. Com o artifício de proteger Portugal, a presença inglesa, que já era imensa, depois do início da guerra, só fez aumentar. Em 1757, mais de cento e quarenta navios e vinte paquetes ingleses adentraram o Tejo. Especialmente os franceses gostavam nada disso.

Em maio de 1759, o enviado francês em Lisboa informou Versailles do mancomunamento das cortes de Londres e de Portugal com a rainha-mãe da Espanha. ${ }^{25}$ Dizia que algo estava sendo tramado contra a França. Desconfiava que os ingleses, que dominavam os mares europeus, fariam alguma emboscada aos navios franceses com apoio dos ibéricos. $\mathrm{O}$ que, em acontecendo, evidenciaria que a neutralidade dos ibérios talvez não era tão neutra. Sendo ou não neutra-neutra, o caso de Lagos, ocorrido meses depois, deu força à convicção do diplomata francês.

Em agosto de 1759, o almirante francês de la Clue conduzia uma esquadra de cinco navios. Oceano, Temeraire, Modeste, l'Amérique e Redoutable. Ia rumo Lagos, em Portugal. Duas léguas do destino, uma esquadra britânica foi avistada. Quatro navios de linha, duas

\footnotetext{
${ }^{23}$ Correspondência do Governador e Capitão-general do Estado do Grão-Pará e Maranhão, Francisco Xavier de Mendonça Furtado, op. cit., vol. 3, carta 143, p. 51.

${ }^{24}$ Quadro elementar, op. cit., tomo 18, pp. 366-368.

${ }^{25}$ Id., p. 368.
} 
fragatas e dois brulotes, barcos com explosivos. Percebendo a rápida aproximação e a clara intenção de lhes acometer, o capitão de l'Oceano abriu fogo. Iniciou com três tiros. Outro capitão francês seguiu o exemplo. Às rápidas, fizeram o que puderam para desembarcar sua tripulação. O mar também conspirava. Estava agitado. La Clue, que estava n'Oceano, conseguiu escapar sem maiores danos. Sorte não similar para os demais. Que tiveram suas naus queimadas ou despedaçadas ou, quando não, caso de l'Amérique e do Redoutable, apossadas. Na contabilidade das vidas, mais de seiscentos homens foram ou mortos ou feridos ou capturados. ${ }^{26}$

Homérica lambança. E em duplo sentido. Ou bem afirmava que a tese da neutralidade era apenas para inglês ver - no caso, para francês ver. Ou bem que Portugal era uma mera extensão de Londres.

A reclamação dos franceses durou anos. $\mathrm{O}$ rei inglês teve que tomar partido e enviar um representante a Lisboa para resolver o mal-entendido. O conde de Kinnoull foi designado embaixador extraordinário para solucionar a "desinteligência" que o almirante inglês causara. O gesto inglês foi importante. Mas não resolveu o problema.

O negócio dos navios aportou mais elementos para a discussão referente à eficácia da neutralidade. Tanto em Portugal quanto em Espanha. Os franceses, muito habilmente, convenceram os espanhóis a entrar, oficialmente, no conflito. Uma guerra protagonizada por aliado e inimigo da Espanha poderia pôr em causa a prosperidade de ambas reais famílias franco-espanholas. Por isso, o tratado, nominado Pacto de família ou parentesco, justificara os motivos da operação como depositários dos "vínculos de sangue" e do "afeto com que reciprocamente se amam". A "amizade" e o "parentesco" precisavam "estabelecer um monumento solene do recíproco interesse, que deve ser a base dos desejos de ambos os monarcas". 27

O pacto se deu no dia 17 de agosto de 1761 e não demorou repercutir. Os ingleses se irritaram de imediato. O que era previsto. Os portugueses, irados, ficaram em sobreaviso. No dia 8 de dezembro, um enviado inglês chegou a Lisboa e passou mais de três horas em despacho com o secretário Sebastião. Não se sabe ao certo o tom da conversa. Mas, a partir

\footnotetext{
${ }^{26}$ Id., p. 371-3.

27 Pacto de família entre os reis da França e da Espanha de 17 de agosto de 1761. In.: Frei Cláudio da CONCEIÇÃO - Gabinete Histórico, op. cit., tomo 15.
} 
daí, o contato dos secretários portugueses com o embaixador espanhol em Lisboa se intensificou. Mas de nada adiantou. No dia 22 de dezembro, o monarca espanhol mandou chamar seu enviado em Londres e declarou guerra à Inglaterra. Ficara progressivamente difícil e custoso para Portugal manter a neutralidade. Nesse momento a França iniciou uma campanha para pulsar o rei José a aderir à guerra. Mas do lado franco-espanhol. ${ }^{28}$

Jacques O’Dunne, pela França, e José Torrero, pela Espanha, ficaram incumbidos da operação-convencimento. Ambos, portadores de memórias políticas reportadas ao rei José, fixaram diversos rendez-vous com Luiz da Cunha, responsável pelos assuntos externos. 16 de março de 1762, foi o primeiro encontro e onde a primeira memória foi entregue. Seu ponto central consistia em afirmar a necessidade de guerra contra a Inglaterra. Do lado francês, o argumento aferia que era preciso impedir que os ingleses continuassem a dominar, despoticamente, os mares. Do lado espanhol, era lembrada a relação de sangue e amizade que unia a península. O destino estaria na mão de parentes, cunhados e amigos. Ambos, franceses e espanhóis, argumentavam a necessidade de se fechar os portos portugueses aos ingleses. Era a maneira mais digna de cooperação. A resposta, negativa, não demorou. Quatro dias depois, no dia 20 de março, Luiz da Cunha comunicou aos dois a posição do rei. Que era sensível à situação e lamentava “o fogo de uma sanguinolenta guerra entre potências". Mas não via razão nem motivo para suspender a aliança secular estabelecida com a coroa inglesa. No dia $1^{\mathrm{o}}$ de abril, os enviados de França e Espanha se renderam novamente ao encontro do secretário português. Dessa vez, o argumento se fazia mais concreto. Acusavam o governo luso de indiferença diante da guerra. Colocavam em questão a efetividade de sua neutralidade. Reapresentavam o caso dos navios de Lagos. Arrematavam com o aforismo que informa que era "preferível a doçura da paz às desgraças da guerra". Luiz da Cunha respondeu imediatamente reafirmando a posição de Portugal. Primeiro: não se podia romper tratados sem motivo; e a Inglaterra não havia dado motivo. Segundo: os tratados entre Portugal e Inglaterra eram imemoriais. A terceira memória foi entregue no dia 23 de abril. Nela se dizia, quase que desesperadamente, que a união das forças queria sacudir a dependência da Inglaterra sobre os portugueses. Dois dias depois, o representante português desqualificou esse argumento, considerando-o mais do mesmo, e deu a última posição do rei que afirmara ser lícito defender a própria casa!

\footnotetext{
${ }^{28}$ Quadro elementar, op. cit., tomo 18, p. 371-3.
} 
Percebendo a irredutibilidade dos desacordos, a corte portuguesa mandou buscar seus José da Silva Peçanha e Pedro da Costa de Almeida, embaixadores portugueses em Madrid e Paris. Concomitantemente, os enviados de Espanha e França foram enfaticamente convidados a se retirar. E o representante da Inglaterra em Madrid foi feito correr. A guerra estava para marchar sobre Portugal. ${ }^{29}$

Com o pacto de família, a Espanha entrou na guerra. A diplomacia francesa não fez outra coisa que instigar espanhóis a forçarem os portugueses ao mesmo. As memórias foram uma tentativa. Mas a resposta inglesa veio instantânea. A corte de Londres conhecia perfeitamente a situação de seu aliado luso. Tudo faltava. Marinha, exército. Navios, tropas. Dinheiro. A carestia era intensa. Ajuda era incontornável. No dia 2 de fevereiro de 1762, dez navios de guerra de bandeira britânica aportaram em Lisboa. Na madrugada de 10 para 11, chegaram mais nove. Vinham guarnecer as guarnições. Ocupar os fortes. Proteger a costa e as posses. Ato contínuo, um e outro navio continuou a chegar. Nada de extraordinário. Nesse entremeio, depois de longas discussões, a corte britânica aprovou um socorro mais de verdade. 8 mil homens bem treinados, bem vestidos, bem alimentados. Lord Tirawley, lord Loudoun e general Townshend para comandos. No mesmo contexto, Portugal importou o conde de Lippe-Buckbourg para comandar o exército local. ${ }^{30}$ A frente espanhola vinha sob o comando do marques de Sarria, marechal espanhol. Em manifesto do dia 30 de abril, Sarria declarou que nenhum português seria maltratado. Seus subordinados solicitariam apenas a boa vontade dos lusitanos em cooperar com auxílios de primeira serventia. Portanto, suas tropas avançavam. ${ }^{31}$ Mas nisso a guerra já estava em vias de terminar. Entre agosto e setembro, diplomatas dos países envolvidos foram chamados a Versailles para as tratativas. Daí saiu o texto do tratado de Paris de 10 de fevereiro do ano seguinte subscrito pelos reis dos países fortemente implicados: França e Inglaterra e seus aliados, Espanha e Portugal.

\footnotetext{
${ }^{29}$ Memórias apresentadas ao conde da Cunha. In.: Frei Cláudio da CONCEIÇÃO - Gabinete Histórico, op. cit., tomo 15, cap. 21; Quadro elementar, op. cit., tomo 2, pp. 248-81.

${ }^{30}$ Quadro elementar, op. cit., tomo 18, pp. 377-9.

${ }^{31}$ Id., tomo 2, p. 280.
} 


\section{O caso dos Távoras}

Belém-Lisboa, 3 de setembro de 1758. Era noite. Pouco mais ou menos onze. O rei José fazia seu passeio costumeiro. Vinha em carruagem. Saíra da porta da quinta do Meio. Rumava para seu palácio. Do outro lado do pequeno campo. No que quebrou a esquina do meio, foi surpreendido por tiros. Não de brincadeira. Era uma tocaia. Por pouco, perfeita. Três homens a cavalo. Munidos a carabinas. Armas de grosso calibre da época. Desferiram, sem piedade, diversos tiros contra o soberano. Ao menos dois dos tiros acertaram. Um de raspão entre ombro e braço. Outro no mesmo braço e no lado direito do corpo. Fim de noite e quase fim de vida para o monarca. Que, no chão, perdia muito sangue. Agonizava. E, como seus súditos maltratados pelo sismo anos atrás, deveria de estar a indagar onde estaria Jesus. Seu cocheiro, invés de rumar para a Ajuda, foi à Junqueira. Casa do cirurgião real. Que imediatamente se ocupou dos dois. O caso era grave. Era de morte. O rei José não pôde retornar no mesmo dia ao seu palácio. E seu restabelecimento foi previsto demorado. Por isso, no dia 7 de setembro decretou sua mulher soberana do reino. Ao longo de mais de dois meses, martirizou. Sua debilidade pôs seus secretários em aviso. Sua passagem do leito ao gabinete foi motivo de festa. Ocorreu no dia 9 de dezembro. Dia em que tornou público o que tinha em segredo com seus secretários Sebastião, Luiz da Cunha e Diogo Corte Real. Resenhou o atentado, o drama que vivera e a estratégia para vingar o causo. Assinou em decreto e mandou publicar em todo Portugal. A execução da vingança ficou a cargo dum tribunal de inconfidência. Cuja presidência, sem nenhuma surpresa, ficaria a cargo do secretário Sebastião. Que já vinha mobilizando, em avanço, na discrição, ministros, desembargadores, brigadeiros, corregedores, tenentes e gente do comum. Por isso, quatro dias após o decreto real, suspeitos foram interceptados. Era manhã do dia 13 corrente, quando fidalgos e gentes d'outras procedências foram surpreendidos. Ao menos um duque, um conde e um marquês foram postos em juízo. Todos os presos, independente de sua origem, tiveram a casa de seus próximos metida em suspeição. Guardas passaram a as guardar noite e dia e noite. Em mês exato, veio a sentença. 12 de janeiro de 1759, quase não houve outro assunto nas gazetas. Ficara fixada a execução para o dia seguinte. Mas desde aquele 12, os réus devieram desnaturalizados e declarados peregrinos e vagabundos. A notícia correu mundo. De boca em boca, gente de toda parte tomava partido. Bem antes do início do espetáculo das execuções, o público se agigantava. Na praça do cais de Belém, de fronte ao palácio que havia sido do conde de Aveiras, um cadafalso de sete palmos de altura foi levantado. 8h30 da manhã começou a matança. Durou toda a manhã e parte da tarde. 11 pessoas foram finadas nesse dia. 
Umas, degoladas; outras, incineradas. Horror e satisfação, frisson e alegria se mesclaram. Entre os desgraçados, Francisco de Assis, Luiz Bernardo e Leonor Thomazia. Marqueses e marquesa de Távora. Fidalgos cuja alcunha "Távora" imortalizou o evento. Francisco de Assis fôra vice-rei na Índia. Outros importantes também receberam a morte. José Mascarenhas, duque de Aveiro. Jeronimo de Athaide, conde de Athouguia. Gente de menor patente também. José Maria, ajudante de Francisco de Assis. Antonio Alvares Ferreira, Manuel Alvares Ferreira e José Miguel, guarda-roupas e criado de José Mascarenhas. Jose Polycarpo de Azevedo, cunhado de Antonio Alvares. Braz José Romero, companhia de Luiz Bernardo. Findo, pôs-se fogo em tudo. Não sobrou que cinzas, lançadas ao mar. Não sobrou que memórias da "grande traição", imortalizadas com sal e dizeres de "aqui morou..." nas casas. $^{32}$

\section{Vinhas da ira do Porto}

A execução dos Távoras e companhia chocou o reino e dividiu opiniões. Mesmo sendo os lusos d'aquém e além-mar acostumados com o inglório espetáculo. Ano e meio antes do horroroso dia 13 de janeiro de 1759, a cidade do Porto assistiu a morte de dezenas de locais. Incluindo mulheres e crianças. Como em 1759, alguns foram açoitados. Outros, enforcados. Muitos, degolados. Em suma, fôra outro dia de festa. Era 14 de outubro de 1757. Razão: sentença contra rebeldes que ousaram contrariar determinações de sua majestade. O ocorrido se deu em fins de fevereiro daquele ano de 1757. No dia 23 de fevereiro, o Lisboa, codinome de José Fernandes da Silva, liderou gigante manifestação contra a Companhia Geral da Agricultura dos Vinhos do Alto Douro. Descontentamento era generalizado. Essa Companhia, também conhecida como Real Companhia Velha, fôra uma das invenções do secretário Sebastião no pós-sismo. Tinha por objetivo, retirar, sutilmente, dos ingleses o monopólio dos vinhos produzidos na região. Pelo decreto de fundação de 10 de setembro de 1756, a Companhia passava a deter o exclusivo da produção e distribuição de vinhos do Douro, donde saíam - e saem - o afamado vinho do Porto. ${ }^{33}$

O ápice da insatisfação ganhou lugar definitivo no carnaval de 1757. 23 de fevereiro foi uma quarta-feira de cinzas. Depois de apanhar a hóstia para iniciar bem a quaresma, entre

\footnotetext{
${ }^{32}$ Frei Cláudio da CONCEIÇÃO - Gabinete Histórico, op. cit., tomo 14, pp. 1-35. Kenneth MAXWELL Marquês de Pombal, op. cit., p. 23-4.

${ }^{33}$ Rui de Figueiredo MARCOS - As Companhias Pombalinas: Contributo para a História das Sociedades por Acções em Portugal. Coimbra, 1997.
} 
o fim da manhã e o início da tarde, liderados pel'o Lisboa, o juiz do povo, dezenas de pessoas se dirigiram à casa do desembargador Bernardo Duarte Figueiredo, responsável local da Companhia. Sem pedir licença, adentraram sua casa e o coagiram. Juntava gente para ver. Ninguém, por certo, para defender o "homem bom" que era Figueiredo. Em uníssono, os manifestantes pediam a extinção da Companhia e o fechamento de todas as tabernas concernentes. Minuto a minuto, a chusma se fazia multidão e a reivindicação se tornava implacável. Nesse clima e concomitantemente, outro grupo tomou de assalto a casa de Luiz Belleza de Andrade, o administrador da Companhia. Em fato, não era uma casa; era uma mansão. De supetão, pedradas foram quebrando vidros e vidraças, e chutes e pontapés foram arrombando portas e entradas. Progressivamente, diversas pessoas invadiam o recinto do nobre Belleza. Móveis e ornamentos foram destruídos. Quadros, danificados. Cortinas, rasgadas. Tudo na "procura" do esconderijo dos livros da Companhia. Encontraram. Festejaram. Queimaram. Seguiram para outras casas. Todos os envolvidos com a Companhia foram visados. Ou seja, todos os "homens bons da cidade do Porto" que, no fundo, serviram de alicerce para aquela iniciativa do secretário Sebastião. Desembargadores, deputados, vereadores governador de justiça etc. todos se puseram em alerta fugindo. A rebelião seguiu nos dias que se seguiram. Era quase uma festa. Continuação do carnaval. Micareta. Diversos refrões de ordem foram confeccionados e cantados continuamente. No entrar da primeira noite, começou uma reação liderada pelo desembargador do paço João Pacheco Pereira de Vasconcellos. À frente dum regimento de cavalaria, Vasconcelos foi recebido com os dizeres de "Aque do povo, morra, fogo, viva o povo" ou/e "Aque do povo, viva o povo, e morra a companhia" e/ou ainda "morra tudo, queime-se esta beleza, deite-se-lhe fogo às casas e queime-se tudo." 34 Diante duma quantidade desproporcional de pessoas, a inteligência do nobre desembargador o forçou a recuar, se retirar para buscar reforço. Enquanto isso, essas novas do Porto chegavam ao conhecimento do rei José e do secretário Sebastião. A gestão do contra-ataque foi posta em obra. Na manhã do dia seguinte, praticamente todas as frentes de guerra das proximidades foram instadas para dar combate. Dragões da Beira mandou um regimento. Infantaria do Minho, dois. Traz os Montes mandou além da infantaria, cavalaria. Desde o Porto, todas as guarnições foram envolvidas e, ao todo, contribuiu com ao menos 1.200 homens. Todos os bairros e distritos foram dominados, vasculhados, acalmados. Todos suspeitos encontrados - ao menos quinhentas pessoas - foram movidos para cárceres. Toda a operação consumiu mais de dois dias e noites. No dia 28 de fevereiro, do desembargador João

\footnotetext{
${ }^{34}$ Frei Cláudio da CONCEIÇÃO - Gabinete Histórico, op. cit., tomo 13, pp. 237-245.
} 
Pacheco foi designado para abrir a devassa. No dia 12 de outubro, foi dada a sentença. 378 condenados. Ao menos 50, à pena capital. ${ }^{35}$

\section{De volta às Tordesilhas}

No dia 10 de agosto de 1759, morreu o monarca espanhol. O rei Fernando era intensamente dado à música e à mulher, dona Maria Bárbara de Bragança. Dona Maria Bárbara era filha do rei João, falecido soberano português. Portanto, irmã de dom José I, corrente soberano luso. A morte de dona Maria Bárbara, em agosto de 1758, acelerou a degradação da saúde de rei Fernando que havia tempo ia mal. Com sua morte, foi sucedido por dom Carlos III. ${ }^{36}$ Sob o rei Carlos, a discussão sobre o tratado de limites de 1750 retomou definitivamente praça. Evidentemente por pressões desde Europa e desde as Américas. Durante todo o decênio, negociações formais e informais tinham sido maneadas. Projetos e contraprojetos, ensaiados. No início de 1760, as negociações finalmente foram seriamente recomeçadas. A sede das discussões foi Madrid. Da parte espanhola, o responsável foi o secretário de estado Ricardo Wall. Do lado português, o rei José conferiu plenos poderes ao seu embaixador na Espanha, José da Silva Peçanha.

O secretário Ricardo Wall era espécie de secretário Sebastião espanhol. Controverso. Poderoso. Corajoso. O embaixador Peçanha era mais habilidoso que poderoso. Madrid, definitivamente, não era o posto mais importante para Portugal nem para quaisquer à época. Consequentemente não possuía o enviado mais importante. De todo modo, ambos, Wall e Peçanha, com plenos poderes, tomaram decisões importantes. Sobre o tratado de limites, promoveram diversas conferências. Avaliaram diversos projetos. Reavaliaram toda a história e prática da negociação. O interesse espanhol sobre esses limites era preponderante. Ainda na primeira metade de 1760, o secretário Ricardo Wall compilou o resultado de todo seu trabalho

\footnotetext{
${ }^{35}$ Kenneth MAXWELL - Marques de Pombal, op. cit., pp. 70ss.

${ }^{36}$ Francisco AGUILAR PIÑAL - Bibliografía de estudios sobre Carlos III y su época. Madrid: Consejo Superior de Investigaciones Científicas, 1988. Miguel AVILÉS FERNÁNDEZ - Carlos III y el fin del Antiguo régimen. Madrid: EDAF, 1973. Antonio DOMÍNGUEZ ORTIZ - Carlos III y la España de la Ilustración. Madrid: Alianza, 1988. Javier GUILLAMÓN - Las reformas de la administración local durante el reinado de Carlos III. Madrid: Instituto de Estudios de Administración Local, 1980. Henar HERRERO SUÁREZ - El monopolio de una pasión: las reales loterías en tiempos de Carlos III. Valladolid: Universidad de Valladolid, 1992. Anthony HULL - Charles III and the Revival of Spain. Washington: Rowman \& Littlefield, 1980. Charles PETRIE - King Charles III of Spain. Londres, 1971. Stanley J. STEIN \& Barbara H. STEIN - El apogeo del imperio: España y Nueva España en la era de Carlos III, 1759-1789. Barcelona: Crítica, 2005. Pedro VOLTES BOU - Fernando VI. Barcelona: Planeta, 1996. Pedro VOLTES BOU - Carlos III y su tiempo. Barcelona: Juventud, 1964.
} 
com embaixador Peçanha e encaminhou ao rei Carlos. No dia 16 de setembro de 1760, o rei espanhol em pessoa rendeu sua avaliação. Sem hesitação, rompeu o trato de 1750. Aos negociadores, Wall e Pessanha, restava negociar os estragos dessa decisão. ${ }^{37}$

O momento era absolutamente tenso para todos os lados. O rei Carlos nem o rei José descartavam que estavam em guerra direta e indireta. O secretário Sebastião nem o secretário Ricardo Wall dissimulavam nesse quesito. Franceses e ingleses alimentavam a fogueira de problemas ibéricos. A discussão sobre o tratado seguiu em aberto. A avaliação do monarca espanhol foi comunicada ao seu homólogo português. O embaixador Peçanha seguiu em Madrid e incumbido de decidir que fazer. As negociações seguiram até o dia 12 de fevereiro de 1761, quando se celebrou o trato del Prado. No fundo, a oficialização a posição do monarca espanhol. A partir dali, o tratado de Madrid de 1750 passava a, definitivamente, nada valer. Dez anos de trabalho simplesmente assim desapareciam.

${ }^{37}$ Quadro elementar, op. cit., p. 244-7. Kenneth MAXWELL - Marques de Pombal, op. cit., pp. 70 ss. 


\section{Outsiders}

Apenas os fracos são submetidos à neutralidade em função dos fortes.

Secretário Sebastião ${ }^{1}$

O homem comum evita seus inimigos, os ponderados tiram proveito deles.

Plutarco $^{2}$

Qui nescit fingire nescit vivere

Lisboa, Porto e Portugal acolhiam muitos estrangeiros naqueles idos dos 1750s e 60s. Franceses, romanos, florentinos, sardos, espanhóis, russos, austríacos, germânicos, ingleses. Assim como diversos tipos deles. Negociantes, viajantes, intelectuais, artistas, homens e mulheres da vida. Cada qual à sua maneira ia marcando o cotidiano da corte e da sociedade lusa. Com o acirramento de conflitos entre os países europeus, a presença de diplomatas e enviados extraordinários ganhou importância. Ora para defender seus compatriotas. Ora para reforçar alianças. O secretário Sebastião, mais mesmo que o secretário de negócios estrangeiros de Portugal, o secretário Luiz da Cunha, passou a despachar frequentemente com esses agentes externos. Tarefa nem sempre tranquila. São algumas dessas intranquilidades que vão esboçadas a seguir.

\section{Castres}

No dia 11 de abril de 1752, dois dos mais notáveis enviados ingleses em terras lusas aportaram em Lisboa. Abraham Castres, embaixador em Portugal, e James O'Hara, Lord Tyrawley, enviado extraordinário. Castres acumulava mais de trinta anos de vida diplomática.

\footnotetext{
${ }^{1}$ Discurso político sobre as vantagens que o reino de Portugal pode tirar da sua desgraça por ocasião do terremoto do $1^{\circ}$ de novembro de 1755. In.: CARTAS e outras obras selectas do Marques de Pombal. Lisboa: Typographia de Costa Sanches, tomo II, 1861. p. 101.

${ }^{2}$ Como tirar proveito de seus inimigos. Trad. Isis Borges B. da Fonseca. São Paulo: Martins Fontes, 2003. p. 4.
} 
Tinha servido em diversos postos. Em Londres e no exterior. Esteve responsável de assuntos ingleses em Lisboa por curto período em 1745. A partir de 1749, foi nomeado para ficar. O'Hara era dos oficiais mais experientes da British army. Filho do marechal Charles O'Hara, iniciara sua carreira como coronel do regimento de fuzileiros reais durante a guerra de sucessão da Espanha. Em seguida, foi coronel e capitão em diversos destacamentos. Participou de ações em numerosas praças de combate. E, entre 1747 e 1756, virou governador da ocupação inglesa de Minorca. ${ }^{3}$ Castres, por seu turno, ausente de Portugal, estava em Londres, para despachos privados com seu soberano e com ministros. Fôra seu primeiro regresso para casa e para a corte depois de 1749. Saíra de Lisboa em fins de junho de 1751. No dia 3 de julho, teve com o diplomata Robert Darcy, $4^{\circ}$ conde de Holdernesse. O propósito era render contas sobre as condições de Portugal auxiliar a Inglaterra em eventual novo conflito. O território português era estratégico. Impunha saber se o reino de Portugal continuava fiel e potencial parceiro. Holdernesse queria saber. O relatório de Castres deu a resposta. "Portuguese policy likely to remain pro-British, as British is the only power that can protect Portugal against her natural enemy, Spain". ${ }^{4}$ Ou seja, continuava a haver espécie de fidelidade compulsória. Mas Castres comunicou também algo sabido, esperado e indesejado: o exército português estava em farrapos.

Essa ida de Castres a Londres foi fruto da grande apreensão dos britânicos com os "novos" portugueses. A corte inglesa queria mais e mais informações sobre a administração que aterrissara no poder depois da morte do rei João. Ano e meio de reinado de dom José e gestão do secretário Sebastião, a preponderância desse secretário sobre todos os assuntos entrou a preocupar. No dia 17 de abril precedente, Castres enviara longa correspondência ao duque de Bedford. Era, no fundo, um relatório detalhado sobre os rumos do império luso. Nele, Castres comentou os rumores da possibilidade de suspensão do tratado de Madrid de 1750. O secretário Sebastião e muitos lisboetas, disse Castres, eram contra e propunham uma convenção mais favorável ao Portugal. No mesmo diapasão, noticiou a surpresa generalizada que a indicação de Francisco Xavier de Mendonça Furtado, irmão do secretário Sebastião, para o governo geral do Maranhão, estava gerando. E arrematou a nota reafirmando a influência das ideias desse braço forte do rei José. ${ }^{5}$ Essa carta motivou a corte inglesa a ter

\footnotetext{
${ }^{3}$ Stuart HANDLEY - Second Baron Tyrawley and Baron Kilmaine (1681/2-1773). In.: Oxford Dictionary of National Biography http://dx.doi.org/10.1093/ref:odnb/20634. Consultado em 10 de julho de 2011.

${ }^{4}$ A. Castres to Earl of Holdernesse. Londres, 3 de julho de 1751. The National Archives - Londres, State Paper Foreing - Portugal, 89/48.

5 A. Castres to Duke of Bedford. Lisboa, 17 de abril de 1751. The National Archives - Londres, State Paper Foreing - Portugal, 89/48.
} 
pessoalmente com Castres. O assunto era delicado e Castres não estava autorizado a tudo dizer em carta. Sobretudo pela crescente hostilização dos ingleses em geral em terras lusitanas.

A administração rei José-secretário Sebastião estava dificultando a vida dos negociantes ingleses em Lisboa. Após a morte do rei João, o recebimento e envio de valores metálicos, ouro e prata, passou a ser sobretaxado e, muita vez, confiscado. Por isso, negociantes ingleses se organizaram em protesto. Confeccionaram representações e colheram assinaturas. $\mathrm{O}$ assunto não tardou a chegar ao conhecimento de Londres. As queixas eram endereçadas ao procedimento do oficial da alfândega. Contrabando de ouro era cogitado. A gravidade da situação impôs a feitura duma comissão especial para entender o que se passava e arbitrar que se poderia fazer. O problema, a princípio, era reconhecido como político. Castres foi a Londres. O'Hara foi convocado para uma conversa direta com Castres sobre o que estava acontecendo. No dia 22 de fevereiro de 1752, O’Hara foi nomeado ministro plenipotenciário em Portugal e recebeu instruções secretas e secretíssimas para aprofundar uma investigação sobre o imbróglio. Queria se saber se as queixas eram, no mínimo, razoáveis. Como complemento, e talvez o mais importante, lhe foi requerido um relatório detalhado da situação do exército português. ${ }^{6}$

O’Hara e Castres retornaram juntos para Lisboa. Uma vez aí, no dia 11 de abril, foram imediatamente recebidos por rei e família real. Tiveram os mais austeros tratamentos.

No dia seguinte, O’Hara iniciou seu périplo. Falou com praticamente todos os ministros portugueses e com todos os representantes ingleses. Conversou também com diversos diplomatas de todos outros países e causou a mais positiva impressão no enviado francês, por exemplo.

Entretanto, os negociantes ingleses estavam nada satisfeitos. Após de uma, duas conversas, passaram a considerar O'Hara medíocre e vendido. Depois de três meses, tempo da costura dos acordos, continuaram acreditando o mesmo. De todo modo, ficou decidido que o governo português devolveria eventuais importâncias confiscadas. E essa devolução teve

\footnotetext{
${ }^{6}$ Secret and Separate instruction for Lord Tyrawly as Minister Plenipotentiary to Court of Portugal. Londres, 22 de fevereiro de 1752. The National Archives - Londres, State Paper Foreing - Portugal, 89/48.
} 
início já no dia 8 de agosto, menos de dez dias depois do regresso de O’Hara para Londres. Mas o clima de animosidades não fora dissolvido. ${ }^{7}$ E atravessou fronteiras.

O enviado português em Londres, Joaquim José Fidalgo da Silveira, homem de leis e de letras, que vinha sendo pressionado desde que assumira o posto em fins de 1750, a partir daquele momento foi quase forçado a ir embora. Era o representante da nova administração lusitana. Primeiro enviado depois da morte do rei João. Os nobres ingleses não o aceitaram desde sua chegada. Nada pessoal. Era uma forma de protestar o tratamento recebido pelos ingleses em Portugal. O clima era de tensão. Mesmo inteirado, o secretário Sebastião postergou o quanto pôde um eventual processo de substituição. Quando não pôde mais, deixou à corte portuguesa a escolha. Esta indicou Freire de Andrade - homem de 50 anos, somados a muito prestígio e prudência. O secretário Sebastião também o segurou o quanto pôde. Esperou a resolução do conflito com os ingleses. Esperou O'Hara ir embora. Quando foi para enviá-lo, mudou a diretiva. Impôs Luiz da Cunha. O rei José aceitou sem mais problemas. Luiz da Cunha chegou a Londres no dia 28 de setembro de 1752 e foi bem recebido pelas comunidades inglesa e portuguesa e logo conseguiu audiência com o rei e com a princesa de Gales. Enquanto isso, Joaquim da Silveira retornava para casa via Dover-CalaisLisboa. $^{8}$

Negociantes ingleses seguiram descontentes em Portugal. Interpretaram o acordo de O'Hara como para português ver. Continuaram pressionando suas lideranças políticas. O secretário Sebastião era tido por adversário. Castres passou a ser visto como conivente. Nesse ambiente, as conversas privadas entre Castres e o secretário Sebastião se multiplicaram. Precisavam encontrar uma saída política para os problemas. Castres não tinha mais o que dizer. De todo modo, no dia 26 de junho de 1753, o lord Holdernesse fez saber aos enviados em Portugal que o rei George estava satisfeito com o desfecho da missão de O’Hara e com a normalização do foreing trade of Portugal. ${ }^{9}$

Mas os protestos continuavam. Em Portugal; na Inglaterra. Em novembro daquele ano, a contestação chegou ao ápice. Willian Shirley, empresário domiciliado em Lisboa, líder de várias manifestações, tentou agredir George Crowle, cônsul geral inglês em Lisboa. O nobre

\footnotetext{
${ }^{7}$ Quadro elementar das relações políticas e diplomáticas de Portugal com diversas potências do mundo desde o princípio da monarquia portuguesa até os nossos dias ordenado e composto pelo visconde de Santarém. Lisboa: Typ. da Academia real das Sciencias, tomo 8, 1864. p. 348-354.

${ }^{8}$ Id., ibid.

${ }^{9}$ Lord Holdernesse to G. Growle. Londres, 26 de junho de 1753. The National Archives - Londres, State Paper Foreing - Portugal, 89/49.
} 
secretário do rei José não admitiu o ocorrido. Por isso, no dia 5 de novembro, deu 24 horas para Shirley deixar Lisboa e 5 dias para deixar Portugal. O cálculo era simples. Expatriando Shirley se estaria teoricamente neutralizando os manifestantes. Foi a leitura dos portugueses e dos ingleses encarregados da burocracia. Por isso, no dia 12 de novembro, Castres comunicou com imensa satisfação o ocorrido à corte inglesa. Depois dos acordos de O'Hara, os comerciantes ingleses não tinham mais que reclamar. Era consenso nas cortes. ${ }^{10}$ Não tardou a aparecerem manifestações de apoio a Shirley e contra o rei José e manifestações de apoio ao secretário Sebastião e a Castres e contra Shirley. O movimento ganhou dimensão tamanha que o secretário Sebastião e o rei José tiveram de recuar e perdoar Shirley. ${ }^{11}$ Essa conduta fomentou o isolamento do enviado inglês. A corte portuguesa não suportava mais as reclamações intermináveis da parte dos negociantes ingleses e interpretava como incompetência de Castres em acalmar seus compatriotas. No início de 1754, o rei José, via seus subordinados, fez público seu descontentamento. O rei inglês foi comunicado. Castres foi repreendido. ${ }^{12}$ De nada serviu. A solução veio apenas com sua morte anos depois.

\section{Les Français}

Porto, fevereiro de 1760. Um corsário francês - leia-se pirata a serviço oficial de seu soberano - rumava para o porto de Vianna do Minho com uma presa, um barquinho, inglesa. Quanto mais se aproximava, mais locais chegavam para ver. Percebendo a cor da bandeira da presa e do predador, negociantes ingleses, abundantes na cidade do Porto, se organizaram em bando e partiram para o cais. Em instantes, se distribuíram por quatro navios. Pequenos navios de pesca. Armaram-nos e se armaram. Nada de muito sofisticado. Foram ao encontro do blue. Não encontraram dificuldades para acometê-lo. Não demoraram a trazer seu capitão ao povo. Muita gente em terra ia se aglomerando. Como de costume. Como se fosse festa. Sem cerimônia, o francês foi escorraçado. Fizeram-lhe toda sorte de humilhação. Toda sorte de constrangimento. Tudo à vista e ao sabor da curiosidade pública do público. O barquinho inglês foi reavido. Os pertences do corsário, confiscados.

\footnotetext{
${ }^{10}$ A. Castres to A. Amyand. Lisboa, 12 de novembro de 1753. The National Archives - Londres, State Paper Foreing - Portugal, 89/48.

${ }^{11}$ Kenneth R. MAXWELL - Pombal and the Nationalization of the Luso-Brazilian Economy. The Hispanic American Historical Review, vol. 48, n. 4, pp. 608-631, nov. 1968.

${ }^{12}$ Quadro elementar, op. cit., tomo 8, pp. 354-5.
} 
A notícia do incidente chegou em tempo real ao conhecimento do enviado do rei Louis na cidade. Esse cônsul francês relatou o mais rápido que pôde ao seu superior em Lisboa. $\mathrm{O}$ conde de Merle, embaixador de França em Portugal, reagiu com uma mistura de raiva e déjà $v u$. Sem demora, nem titubeio, foi ter com o secretário Sebastião. Sem agendar, sem nada, chegou chegando. Com suas credenciais de embaixador, passou fácil pela guarda do luso secretário. Em minutos, estava diante do próprio. Na seguida dos cumprimentos habituais, se pôs a narrar o ocorrido do Porto. O secretário Sebastião, por certo, já sabia de tudo. Antes que Merle avançasse na explanação, o nobre secretário então cerrou os ouvidos se recusando a ouvir. Fora de qualquer código de finura ou decoro, ordenou que o mais alto representante de França em Portugal se calasse. Disse não ter nada que ver com o caso. Nem tempo, paciência ou interesse para falações. Merle insistiu. O secretário Sebastião também. Redisse: não. Disse que somente o secretário de negócios estrangeiros, Luiz da Cunha, poderia, eventualmente, dar ouvidos ao fato. Merle retrucou referindo que Luiz da Cunha, como do conhecimento de todos, estava em Londres e, em assim sendo, o secretário Sebastião deveria de ser o responsável. O secretário disse nada. Merle, em assim sendo, questionou quem respondia pela secretaria do exterior na ausência de seu ministro. O secretário seguiu calado. Merle insinuou ser o secretário dos secretários. O secretário em questão esnobou, deu as costas e saiu. Deixou Merle às paredes. Sem mais que fazer, Merle se foi e, ainda envolvido pela irritação do momento, relatou o ocorrido ao seu chanceler em Versailles. ${ }^{13}$

Meses depois, outro constrangimento teve lugar. O dia era 6 de maio. Local, Lisboa. Endereço, casa de Merle.

Depois da lida, em um momento de descontração, o cozinheiro de confiança do embaixador francês conversava com a criadagem, colegas e amigos, no hall de entrada. Pelas tantas, o olhar insistente de alguns passantes lhe congelou. Eram ingleses. De rosto e de farda. Marinheiros. Oito ao todo. Iam fazendo a segurança d'um oficial que vinha e ia não se sabe para onde. Pararam. Olharam e olharam até ter certeza. Tiveram. O cozinheiro também. Eram conhecidos. Pouco tempo antes, o cozinheiro tinha estado prisioneiro de guerra e tinha ficado sob a vigilância dos mesmos passantes que agora, surpresos e irados, lhe observavam com olhar de quem ama. Num instante, estavam cara-a-cara. Sem nada dizer, sacaram o cozinheiro para o meio da rua e começaram o espancamento ali mesmo. O oficial foi o primeiro a açoitar o pobre francês pobre. Meteu-lhe a mão na goela e ensaiou seu enforcamento. Foi tudo muito

\footnotetext{
${ }^{13}$ Merle. Archives du ministère des affaires étrangères - Paris. Mémoires et documents - Portugal, 1 - avulsos. Quadro elementar, op. cit., tomo 6, pp. 200-1.
} 
rápido. Os colegas do infeliz demoraram a reagir. Hesitavam. Não sabiam que fazer. Uns gritaram. Outros corriam. Quando se viu, estavam todos embolados em socos e pontapés.

Les britaniques, fisicamente melhor preparados, batiam sem dó. Sua intenção era visivelmente matar. Foi nesse propósito que o oficial inglês desembainhou sua espada. Mas antes que ocorresse o pior, o secretário de Merle gritou imponente e imperiosamente desde sua janela e, quase por encanto, conseguiu impedir desgraceira maior. Nisso outras autoridades francesas se achegaram. E, mais por sorte que qualquer outro recurso, nenhuma vida foi ceifada.

Merle ficou pasmado com o récit. Custou a acreditar. Foi preciso ver para crer. Sua criadagem ficou em frangalhos. No mesmo instante, foi falar com Luiz da Cunha, que já estava de volta. Luiz da Cunha, disse Merle, foi inacreditavelmente gentil. Mas sua resposta não passou de mero retórico sinto muito. ${ }^{14} \mathrm{Ou}$, quem sabe, um mais sutil e penetrante "perdoe-me e esqueça-me".

Descaso, arrogância, cinismo, esnobismo. Assim se tratavam os adversários e inimigos. Dum lado e doutro. Portugal era terreno minado para franceses. Como Espanha o era para ingleses. Os conflitos eram mais que somente institucionais. A violência era, quando não física, simbólica. Não alinhados corriam riscos. Tanto pelas ruas como pelos mares. Ingleses estavam por todos os cantos. A British navy era um pesadelo soturno e onipresente. Nenhum francês, do povo ou da corte, esquecera Lagos. O incidente do porto de Vianna do Minho só fez realçar. Depois de Lagos, a relação franco-luso-britânica só fez se estressar.

\section{Homens - e mulher - de Louis XV}

François-Joachim de Pierre de Bernis, Étienne-François Choiseul e Jeanne Antoinette Poisson. Personagens que merecem un mot. Bernis, Choiseul e madame de Pompadour redefiniram a política externa francesa da metade dos setecentos. Bernis e Choiseul foram diplomatas e secretários de estado. Madame de Pompadour ${ }^{15}$, protetora pública e privada dos dois.

Bernis era homem de letras e de lábia. Padre, cedo conquistou respeito e reconhecimento públicos pela lírica de seus versos. Voltaire, Casanova, Verney foram alguns

\footnotetext{
${ }^{14}$ Quadro elementar, op. cit., tomo 6, pp. 228-30.

${ }^{15}$ Évelyne LEVER - Madame de Pompadour. Paris: Perrin, 2003.
} 
de seus admiradores e interlocutores. ${ }^{16}$ Em 1744, foi eleito para L'Académie Française. Por esse momento, passou a compor o entorno de amizades de madame de Pompadour. Não demorou a ser admitido como seu novo protegido. Essa proteção lhe conferiu acesso à corte e ao rei em pessoa. Em 1752, iniciou sua carreira diplomática. Foi designado para Veneza. Dispensou três anos nessas terras. Conheceu gente. Aprimorou sua leitura, visão e compreensão da Europa. Quando a tensão da Inglaterra sobre a França se impôs, foi solicitado em Paris. Participou de diversas conferências de análise de conjuntura com o próprio rei Louis XV. Para maquinar alianças, foi designado, pelo conselho de estado, para servir em Madrid. Jamais assumiria. Os fatos tinham sido mais velozes. Madame de Pompadour insistiu que o rei lhe enviasse para a Áustria, onde seria mais providencial. Não foi o caso. A partir de setembro de 1755, foi dado início às negociações entre Viena e Versailles, e a Áustria veio a Bernis. O objetivo último era o restabelecimento de aliança. Do lado de lá, estiveram rainha Maria-Thérèza e seu ministro plenipotenciário. Do lado de cá, madame de Pompadour e Bernis. Bernis foi decisivo na feitura das entrevistas e nas confidências. Por fim, o alvo do negócio foi duplamente acertado. França e Áustria se uniram contra a Inglaterra. Áustria e França se uniram contra a Prússia. Essa negociação lançou Bernis no coração da corte. Ele se tornou oficialmente guardião de segredos reais. Nesse entremeio, arquitetou um plano de unidade geral e segurança recíproca para os países europeus excluindo, obviamente, a Inglaterra. Essa proposta motivou o monarca francês a nomeá-lo enviado em Viena. Bernis, novamente, não assumiria. Por outro lado, ganhou uma residência em Versailles e passou a integrar o conselho real como ministro de estado. No dia 28 de julho de 1757, foi empossado ministro das relações exteriores da França. ${ }^{17}$

A Inglaterra vinha em toda ascensão. A França estava desgastada. Sem dinheiro. Sem soldados. Sem apoio de seu povo francês. Portanto, com reduzidas alternativas. Nesses termos, Bernis assumiu uma convenção de não-belicismo. Em seus marcos, "faire la paix à tout prix." Para executar essa nada fácil tarefa, Bernis implantou conversa como estratégia. Sua intenção era ampliar as alianças e multiplicar seu conhecimento da real realidade dos outros. Sob esse desígnio, espalhou homens pelas mais variadas cortes europeias e criou, também, uma imensa rede de espionagem. Ou, eufemisticamente, como se quis, une diplomatie du secrète.

\footnotetext{
${ }^{16}$ Correspondence du cardinal de Bernis, Ministre d'État, avec M. Paris du Verney, Conseiller d'État, depuis 1752 jusqu'em 1769, précédée d'une notice historique, 1790.

${ }^{17}$ Lucien BÉLY et all - Dictionaire des ministres des affaires étrangeres. Paris: Fayard, 1995. pp. 158-66.
} 
As palavras e os ouvidos não conseguiram serenar a fúria dos navios e dos canhões ingleses. A armada francesa seguiu apanhando. A credibilidade de Bernis foi se desgastando. Sua saúde também. O estresse de operações militares, diplomáticas e políticas se lhe tornou insuportável. Por isso, após receber o esperado título de cardeal, começou a negociação de sua aposentadoria. ${ }^{18}$ Antes de pedir oficialmente demissão, preparou e indicou seu sucessor. Choiseul, enviado francês em Viena.

Choiseul era militar proveniente de antiguíssima nobre família francesa. Quatro anos mais jovem que Bernis - nascera em 1719 e Bernis em 1715 -, se casou com uma das mulheres mais ricas da França, a irmã da duquesa de Gontault, que acabou por introduzi-lo no círculo de madame de Pompadour. Sempre ela. Isso se dera pelo início dos cinquentas. Nos chás da madame, conheceu Bernis. Em 1753, foi nomeado enviado em Roma. Seu primeiro posto diplomático. Depois foi movido a Viena. Isso em 1756, a pedido de Bernis e madame de Pompadour, para aprofundar o processo de alianças. Dois anos depois, Bernis o recomendou para lhe substituir. Em carta pessoal ao rei, disse com todas as letras que Choiseul era "le seul" capaz para assumir o cargo. Razões múltiplas. Era militar. Profundo conhecedor da Europa. Exímio político. Refinado estrategista.

Com isso, veio a ser ministro das relações exteriores e operou o ministério, oficialmente, de 1758 a 1761 e, de fato, até o fim da guerra de sete anos. ${ }^{19}$ Seu ministério estabeleceu uma política mais pragmática e menos "romântica". Deixou claro que não podia confiar nem acreditar na política de alianças por alianças. Com a morte do marechal BelleIsle, em janeiro 1761, assumiu o departamento de guerra. De modo estanque, conduziu seu primo, Choiseul-Praslin, ao ministério das relações exteriores.

Os desafios eram imensos. A França perdia no continente e além-mares. Inglaterra e aliados já tinham se apoderado do Canadá, de Pondichéry, do Senegal, das Antilhas. Nesse contexto, o pacto de família era como a jogada de misericórdia. A garantia recíproca de terras de possessões de França e Espanha e Nápoles e Parma era o objetivo. Não se podia perder mais terra. Nesse espírito, foi forjada a paz. Que só veio em fins de 1762 -começos de $1763 .{ }^{20}$

\footnotetext{
${ }^{18} I d .$, p. 166.

19 Mémoires du Duc de Choiseul. Préface et textes de liaison de Jean-Pierre Guicciardi. Notes de Philippe Bonnet. Paris: Mercure de France, 1982.

${ }^{20}$ Lucien BÉLY et all - Dictionaire des ministres des affaires étrangeres, op. cit., pp. 166-179. Paul KENNEDY - The Rise and Fall of the Great Powers. Economic Change and Military Conflict from 1500 to 2000. New York: Random House, 1987. p. 147 ss.
} 
Merle

No dia 6 de maio de 1759, Edward Hay, enviado inglês em Portugal, informou a sua corte em Londres da chegada do novo embaixador francês a Lisboa. Não entrou em detalhes. Comentou apenas que viera com a mulher, a bela madame Marie-Anne Peirenc de Moras. ${ }^{21}$ Nada mais. Essa notícia, aparentemente corriqueira, era da maior importância. Merle era o homem de Pompadour-Bernis-Choiseul. Gozava de confiança irrestrita. Foi praticamente a primeira decisão e indicação de Choiseul ao assumir o ministério das relações exteriores da França. Não que o conde de Baschy, antecessor de Merle, não estivesse desenvolvendo bom trabalho. Questão foi que estava desgastado. Portugal, sabida e consensualmente, não era dos melhores dos mundos para os diplomatas franceses. Com o progresso da guerra, ia ficando longe do paraíso. Charles-Louis, o conde de Merle, provinha duma tradicional família de Beaujolais e Dauphiné. Sua missão era pôr em prova a nova estratégia diplomática francesa adaptada por Choiseul. Para os ingleses, do embaixador ao homem do povo, àquela altura, independente de quem fosse, vindo da França era bastard. Assim, o enviado inglês em Lisboa, mais que nunca, tinha obrigação de segui-lo e observá-lo e assediá-lo e entendê-lo. Neutralizá-lo se necessário. Mais que imediatamente Hay deu jeito de ter com Merle. Em menos de duas semanas, enviou sua ficha completa ao chanceler inglês William Pitt. Contrária a toda pré-impressão, o embaixador Hay teve a mais amistosa sensação do colega francês. Disse ser Merle um monsieur modesto, tranquilo e humilde. Conversável. Inteligente. Discreto. E, em linhas gerais, inclusive, interessante. ${ }^{22}$

No dia 13 de dezembro de 1758, Choiseul assumiu a secretaria de estado exterior francês. No dia 15 de janeiro de 1759, Merle recebeu o pacote com o mémoire d'instrucition que trazia a radiografia francesa da corte portuguesa e os conselhos indispensáveis para se viver por lá. A missão de Merle seria acompanhar a movimentação portuguesa na guerra. Isso majoritariamente. Em caso de brecha, o enviado francês deveria também seguir o casamento

\footnotetext{
${ }^{21}$ E. Hay to R. Wood. Lisboa, 6 de maio de 1759. The National Archives - Londres, State Paper Foreing Portugal, 89/51, folio 153.

${ }^{22}$ E. Hay to W. Pitt. Lisboa, 19 de maio de 1759. The National Archives - Londres, State Paper Foreing Portugal, 89/51.
} 
da princesa do Brasil e tentar promover o reestabelecimento e o melhoramento do comércio Portugal-França. $^{23}$

No dia em que recebeu o mémoire, o processo dos Távora em Lisboa ainda não tinha sido levado a cabo em Lisboa. Mas o atentado ao soberano luso, no setembro passado, era o pretexto ideal para novo enviado francês aterrissar em Portugal. Esse foi um dos cálculos de Choiseul. O outro era fazer Merle se demorar o mais possível em Madrid antes de seguir para Lisboa. Em terras espanholas deveria visitar os habitantes del Prado. Falar com os enviados franceses e estrangeiros. Quanto com mais, melhor. Colher instruções dos espanhóis. Informações sobre os ingleses. Notícias de Portugal. E, não menos importante, interiorizar o jeito ibérico de ser. Acostumar com o clima e com a temperatura, sensivelmente mais seco e mais quente. A aliança de Versailles com Madrid era uma realidade. Passar mais tempo que o habitual com os espanhóis era uma forma de marcar sua chegada às terras lusas. ${ }^{24}$

A ênfase do mémoire recaía, sem ser surpresa, sobre duas personagens: o rei José e o secretário Sebastião.

O rei português era visto como doce e justo. Amante da vida e de tudo que de bom que ela poderia proporcionar. Preguiçoso. Pouco dado ao trabalho. Mimado. Dado a delegar. Dependente.

Ao secretário, a verve francesa era viperina. Ele era visto como medíocre. Ciumento. Cínico. Despótico. Vaidoso. Ressentido. Mau-caráter. Perigoso. Astuto. Imperioso. Opressor. Para ficar nos adjetivos mais recorrentes.

O trato com ambos deveria ser prudente, insistia o mémoire. Desde a França, se acreditava que o pós-atentado ao rei José tinha mudado a conjuntura interna. Sugeria que o rei tinha tido seus hábitos e humor alterados. Que estava menos previsível. O secretário Sebastião, em contraponto, estava mais imperativo e hiperativo. Seu autoritarismo estava no auge. Era mais e mais a autoridade maior "sans avoir le titre de premier ministre". Também

\footnotetext{
23 Mémoire pour servir d'instruction au sieur comte de Merle, cornette de la première compagnie des mousquetaires de la garde du roi, allant a Lisbonne em qualité d'ambassadeur de as majesté auprès du roi de Portugal. Versailles, 15 de janvier 1759. Archives du ministère des affaires étrangères - Paris. Mémoires et documents - Portugal, 1.

${ }^{24}$ Recueil des instructions donnés aux ambassadeurs et ministres de France depuis les traités de Westphalie jusqu'a la Revolution Française publié sous les áuspices de la commission des Archives diplomatiques au Ministère des affaires étrangéres. Portugal - avec une introduction et des notes par le Vte. De Caix de SaintAymour. Paris, ancienne librairie Germer Baillière et Félix Alcan, éditeur, 1886.
} 
porque, mais que nunca, estava tirando proveito do atentado ao rei para oprimir a nobreza local e humilhar a estrangeira.

Os primeiros meses de Merle na corte portuguesa foram impecáveis. De maio a agosto de 1759, não passou de mero observador. Amistoso e gentil. Cordato e discreto. Ocupou seus dias conferenciando com os enviados estrangeiros. Falou com praticamente todo o corpo diplomático. Conquistou a intimidade dos embaixadores de Espanha e Áustria, aliados da França. Teve boas conversas com Luiz da Cunha e com o próprio secretário Sebastião.

O assalto de Lagos mudou tudo.

Depois que os barcos franceses foram massacrados pelos ingleses em terras lusas, foi impossível manter a discrição. Versailles reivindicava diariamente explicações do governo português. Na condição de enviado, Merle ficou incumbido de falar com os secretários Sebastião e Luiz da Cunha sobre o assunto. O objetivo era, sobretudo, questionar qual era a qualidade daquela neutralidade portuguesa. A insistência e inconveniência estafaram os secretários do rei José. Depois da segunda semana, ambos passaram a recusar a visita do enviado francês.

O incidente de Lagos, em verdade, aceleraria o fluxo dos acontecimentos. Tanto da guerra europeia quanto das relações internas. O enviado inglês em Lisboa não tinha o que dizer. O secretário Sebastião ficou revoltadíssimo. Desde Londres, a alternativa foi promover o mea culpa. $\mathrm{O}$ atentado poderia precipitar os movimentos da guerra. $\mathrm{O}$ espaço marítimo de Portugal fôra invadido. A dignidade da França, afetada. O conselho inglês decidiu enviar o conde de Kinnoull com palavras do rei George aos portugueses e aos franceses. ${ }^{25}$ Além do problema Lagos, Kinnoull teria mais duas incumbências. Tratar do descontentamento dos ingleses em Portugal e acompanhar de perto o estado luso na guerra. Mesmo sem Lagos e sem a guerra, mais dia menos dia, seria imperativo alguém de Londres para negociar a situação dos ingleses no Porto. Esses negociantes estavam cada vez mais barulhentos. ${ }^{26}$

\footnotetext{
${ }^{25}$ Lucien BÉLY et all - Dictionaire des ministres des affaires étrangeres, op. cit., pp. 158-66. Quadro elementar, tomo 6, pp. 183-4.

${ }^{26}$ Royal instructions for the Earl of Kinnoull as Ambassador Extraordinary and Plenipotentiary of King Joseph I. Londres, 18 de janeiro de 1760. The National Archives - Londres, State Paper Foreing - Portugal, 89/52. Separate Instructions for the care of Kinnoull. Londres, 18 de janeiro de 1760. The National Archives Londres, State Paper Foreing - Portugal, 89/52.
} 
No dia 29 de janeiro, Merle enviou para Versailles sua interpretação dos interesses da Inglaterra com o envio de Kinnoull. Em conclusão, acreditava que a questão central era nem Lagos, nem os negociantes ingleses. A vinda era para impor "um trabalho sujo" a Portugal. Com uma dívida de mais de 112 milhões de libras e a diminuição progressiva da popularidade da guerra, o objetivo da Inglaterra era, para Merle, forçar Portugal a se impor sobre Sacramento para ampliar a quantidade de súditos e, consequentemente, de fundos. ${ }^{27}$

Entre 7 e 8 de março, Kinnoull aportou em Lisboa. Foi recebido pela corte. O rei José compareceu em pessoa. Houve festa de recepção. Durante o evento, Kinnoul teve longa conversa com o secretário Sebastião e rascunharam já ali estratégias de atuação. Conversar com Merle lhe seria inevitável. Depois do rei José, o enviado francês era o interessado maior do caso de Lagos. Mas antes de ter com ele, já o tinha por causador de caso. ${ }^{28}$ Além de desculpas formais, caberia a Kinnoull - e ao secretário Sebastião - decidir se devolveria, e como e quando, os barcos de guerra franceses destroçados e queimados em Lagos. Era consensual a importância e a gravidade do caso.

Estando em campo, o enviado inglês teve a clara dimensão da tensão. Todos estavam excitados. Participou William Pitt, seu chanceler em Londres, do iminente rompimento da França com Portugal. Lisboa era um barril de pólvoras, dizia. Qualquer faísca poderia desencadear o agravamento do problema. Desde Londres, isso tudo era sabido. Mas, in loco e naquele momento preciso, Kinnoull percebeu que o assunto era ainda mais delicado. ${ }^{29}$

Como Merle estava desmoralizadíssimo em Lisboa, quando da visita de Kinnoull, Choiseul enviou as demandas francesas diretamente para o endereço da corte luso-britânica. Duras demandas. Kinnoull decodificou a mensagem de Choiseul para Pitt. Descreveu que depois de Lagos, Portugal seguia ainda mais em perigo. Versailles estava claramente incitando as forças espanholas e preparando as suas próprias para invadir o território português. Não necessariamente o europeu. O Brasil era o alvo. O projeto era entrar via Cayenne pelo norte, acessando a Amazônia, e via Argentina e Montevideo, pelo sul, para

\footnotetext{
${ }^{27}$ Quadro elementar, op. cit., tomo 6, pp. 188-99.

${ }^{28}$ Earl of Kinnoull to W. Pitt. Lisboa, 10 de março de 1760. The National Archives - Londres, State Paper Foreing - Portugal, 89/52.

${ }^{29}$ Earl of Kinnoull to W. Pitt. Lisboa, 14 de abril de 1760. The National Archives - Londres, State Paper Foreing - Portugal, 89/52.
} 
abocanhar Sacramento, o Rio Grande de São Pedro, a ilha de Santa Catarina etc. ${ }^{30}$ No dia 30 de maio, Pitt respondeu longamente a Kinnoull e ao secretário Sebastião. A mensagem do rei George reforçava o hand by hand dizendo estar em stand by para se por acaso. E sugeria que os franceses iriam ter de engolir eventual atrevimento contra Portugal. ${ }^{31}$ Ou seja, Kinnoull, $d r$. Sebastião: fiquem tranquilos.

Antes desse quiproquó todo, Merle esteve com Luiz da Cunha e esteve com Kinnoull. Quatro dias depois da chegada de Kinnoull, no dia 11 de março, Merle foi recebido por Luiz da Cunha. A conversa foi longa. Mais que o habitual, estranhou o francês. O assunto, mais que o caso do porto de Vianna do Minho, foi o desrespeito do secretário Sebastião. Luiz da Cunha até que tentou pôr panos quentes. Prometeu tomar conta do caso pessoalmente para restituir o que fôra afanado e punir quem merecer. Merle não se convenceu. Por isso, o posto do enviado português em Paris passou a correr risco. Choiseul passou a pressionar o abade Salema.

Mês e pouco depois, Luiz da Cunha convidou Merle para o jantar do corpo diplomático em homenagem ao enviado extraordinário inglês. Nesse jantar, lhe entregou cartas a serem enviadas a Versailles, ao rei Louis e ao chanceler Choiseul, pedindo perdão pelo incidente do porto de Vianna do Minho e comunicando os procedimentos empregados. A impressão de Choiseul ao ler as cartas não foi outra. Disse, de imediato, que embora firmadas por Luiz da Cunha, quem falava era o secretário Sebastião. A missão de Merle, nesse sentido, estava profundamente comprometida. Nada mais que o cinismo alimentava as relações diplomáticas entre Lisboa e Versailles. ${ }^{32}$

No dia 13 de maio, a ira da corte lusitana a Merle foi oficializada. Nesse dia, o abade Salema foi a Versailles e entregou pessoalmente uma memória, com dezessete artigos, de queixas ao enviado francês em Lisboa. Arrogante. Indiscreto. Ousado. Mal-educado. Foram alguns dos adjetivos utilizados pelo abade. A memória era uma encomenda do secretário Sebastião. ${ }^{33}$ Não existia mais clima para Merle em Lisboa. Ninguém dos da cúpula em serviço

\footnotetext{
${ }^{30}$ Earl of Kinnoull to W. Pitt. Lisboa, 16 de abril de 1760. The National Archives - Londres, State Paper Foreing - Portugal, 89/52 - folios 73-8 e 81-87.

${ }^{31}$ W. Pitt to Earl of Kinnoull. Londres, 30 de maio de 1760. The National Archives - Londres, State Paper Foreing - Portugal, 89/52 - folios 51-61.

${ }^{32}$ Quadro elementar, op. cit., tomo 6, pp. 220-4.

${ }^{33}$ Memória do Abade Salema com queixas contra o conde de Merle. In.: Quadro elementar, op. cit., tomo 6, pp. 221-241.
} 
da corte lusa mais o reconheciam como embaixador. O ríspido tratamento entre eles deixou até Kinnoull surpreso. ${ }^{34}$

Merle foi embora. Saint-Julien, cônsul francês em Lisboa, foi designado para ser espécie de olho absoluto. Falar pouco. Menos ainda com os inimigos. Sair pouco. Aguardar ordens. De Versailles; de Madrid. Cuidar da correspondência. Ser "observador judicioso, historiador fiel", instruía Choiseul. ${ }^{35}$ Continuaria cônsul. Não tinha permissão lusa para ser embaixador. Mas como parte do corpo diplomático, poderia se dirigir a Luiz da Cunha. Em todas as oportunidades que tivesse, deveria falar de Lagos. Tudo em vão. ${ }^{36}$ A aliança lusobritânica só fez hesitar. Nesse mesmo momento, chegou a Lisboa o novo enviado espanhol, José Torrero. Poderia ser o início da reação.

\section{Inimigos}

"Que o tempo e os sucessos façam se arrepender os portugueses de terem faltado naquela ocasião com o que deviam à soberania e à coroa do Rei seu amo." ${ }^{37}$ Era o pacto de família em marcha. Foi a manifestação mais que clara de Choiseul para Saint-Julien cerca de um mês antes da assinatura definitiva do pacto franco-espanhol. Era, portanto, julho de 1761 . O plenipotenciário espanhol Girolamo Grimaldi e o próprio secretário Ricardo Wall estavam em Paris. ${ }^{38}$ Essa presença somada ao momento deve ter feito Choiseul carregar nas tintas para escrever aquela afirmação. Efetivamente o raciocínio do ministro francês era decididamente pro-Portugal.

Em junho do ano precedente, quando Merle ainda andava por Lisboa, uma frota de navios portugueses foi destroçada no canal da mancha pela armada inglesa. $O$ incidente não surpreendeu, mas deu ideias a Choiseul. Não se tratava de fato isolado. Bem do contrário, recorrente. A "tirania" inglesa, advertia o francês, era progressivamente contra todos. Mesmo contra os aliados. Mesmo contra Portugal. Choiseul chegou a pedir para Merle pulsar a

\footnotetext{
${ }^{34}$ Earl of Kinnoull to W. Pitt. Lisboa, 7 de junho de 1760. The National Archives - Londres, State Paper Foreing - Portugal, 89/52. Earl of Kinnoull to W. Pitt. Lisboa, 21 de junho de 1760. The National Archives - Londres, State Paper Foreing - Portugal, 89/52 - folio 108.

${ }^{35}$ Quadro elementar, op. cit., tomo 6, p. 274.

${ }^{36}$ Id., pp. 274-7.

${ }^{37}$ Quadro elementar, op. cit., tomo 7, p. 15.

38 G. BENZONI - GRIMALDI, Girolamo. In.: DIZIONARIO Biografico degli Italiani. Roma: Istituto dell'Enciclopedia Italiana, vol. LIX, 1998.
} 
opinião dos portugueses nesse sentido. Mas Merle era ninguém para os portugueses. Não conseguiu levar a cabo. Mas a orientação ficou.

Junho-Julho de 1761, portugueses e ingleses se puseram preocupados com as tramas franco-espanholas. Pressentiam que manobra de envergadura estava em arquitetura. A incerteza conduzia a inquietude. O secretário Sebastião estava atipicamente preocupadíssimo, contou o cônsul inglês em Lisboa. Sir H. Frankland estava responsável dos correios. Edward Hay, como o secretário português, estava consumido pela atualidade da guerra. Essa preocupação imoderada advinha da movimentação dos espanhóis. A cúpula do governo do rei da Espanha estava em Versailles. O secretário Sebastião sabia das fragilidades de Portugal. Sobretudo da insegurança das fronteiras. E, concomitantemente, não estava seguro de ajuda imediata dos ingleses se por acaso. Luiz da Cunha estava em Londres desde maio. Acenos de apoio inglês eram bastante tímidos. Inclusive porque, na verdade, não era consenso entre os ingleses que a França tivesse competência para persuadir a Espanha a invadir Portugal. O embaixador Hay era um dos que duvidavam. E Hay, além de homem de convicções e também por sê-lo, era ouvido em Londres. Suas posições tinham força e peso. Para ele, agressões espanholas contra Portugal poderiam eventualmente ocorrer. Mas não seriam nada de extraordinário. Existiria impacto maior somente se a França se apresentasse fisicamente. E essa possibilidade não lhe parecia plausível. As dificuldades financeiras francesas eram públicas e sabidas. Hay tentava convencer o secretário Sebastião. O secretário não se deixava persuadir. Seguia inquieto. ${ }^{39}$

Veio o 15 de agosto. Le pacte d'amitié foi assinado. ${ }^{40}$ Alguma ofensiva seria obrada. Hay seguia duvidando. O secretário Sebastião seguia matutando. O enviado de França em Londres, imergido no palavrório inglês, tendia a partilhar da opinião de Hay. Desacreditava do poder de fogo espanhol e do ânimo francês. Não era, em absoluto, a impressão do enviado inglês em Paris que cogitava que "Spain is likely to attack Portugal". ${ }^{41}$ Likely to seguia muito diferente de is going to. Choiseul sabia perfeitamente e apostava na negativa. Acreditava no poder de convencimento da diplomacia francesa. Por isso, iniciou o processo de nomeação de um novo embaixador para Portugal. Jacques O’Dunne foi o escolhido. Em seguida, um longo

\footnotetext{
${ }^{39}$ Sir. H. Frankland to R. Wood. Londres, 18 de julho de 1761. The National Archives - Londres, State Paper Foreing - Portugal, 89/53 - folios 157-71.

40 Tratado llamado Pacto de família ajustado entre su Magestad Católica y su Magestad Christianíssima, em Paris à quince de agosto del año mil setecentos sessenta y uno. In.: Coleccion de los tratados de paz, alianza, comercio \&c. ajustados porla corona de España com las potencias extrangeras desde el reynado del señor don Felipe quinto hasta el presente. Madrid en la Imprenta real año de 1796.

${ }^{41}$ Comentário avulso e secreto. Paris, 22 de setembro de 1761. The National Archives - Londres, State Paper Foreing - State Paper Foreing - France, 78/252.
} 
e complexo, mas rápido, processo de formalização da nomeação. Não se sabia se o melhor era um embaixador ou um enviado plenipotenciário. Um embaixador poderia ser tido como um novo Merle. Um plenipotenciário poderia pôr em suspeição redobrada a intenção da França. Fato era que havia mais de ano que a França estava sem embaixador em Portugal. Saint-Julien era cônsul. E fazia mais tempo ainda que a França não enviava alguém em missão especial. Para somar, quando Merle ainda estava em Lisboa e por conta de sua "impertinência", o governo luso impusera um novo regimento para ministros estrangeiros. Uma espécie de código de conduta. O’Dunne precisava de liberdade total. Seu caráter, portanto, foi de plenipotenciário. Em seguida, foi lhe mandado preparar uma resenha de todos os movimentos ingleses de guerra dos últimos meses. Todas as estratégias. Todas as análises. Todos os comentários. Todos os comentários dos comentários. Por outro lado, todos os movimentos franceses no mesmo período. Enquanto isso, o gabinete de Choiseul preparava o novo mémoire d'instruction. ${ }^{42}$ No dia 15 de novembro, O’Dunne esteve com o rei francês. No mesmo dia, recebeu o mémoire. Curto se comparado aos dos demais enviados no último decênio, mas com eloquência e objetividade desproporcionais.

La cour de Londres ne se prescrivant aucunes bornes dans le projet qu'elle paroit avoir formé de dominer despotiquement sur toutes les mers, et ne laisser aux autres nations qu'une navigation et un commerce précaire, le Roi d'Espagne a pris la sage et généreuse résolution d'unir ses forces à celles du Roi, pour mettre un frein à l'ambition injuste et à la cupidité démesurée des Anglois. ${ }^{43}$

O inimigo era a Inglaterra. Ponto. Inimigo declarado. Inimigo inimigo. Portugal estava de vítima na história. Não era outro o objetivo de O'Dunne senão ampliar o traité d'amitié com a participação do rei José. Nos termos do mémoire, quebrar a neutralidade de Portugal para o lado de França e Espanha.

Dura missão.

No dia 16 de novembro, O’Dunne saiu de Paris rumo Lisboa, com escala em Madrid. Para o rei Carlos, levava especiais cumprimentos. Para seus ministros, recomendações. Para o

\footnotetext{
${ }^{42}$ Correspondences de Portugal. Archives du ministère des affaires étrangères - Paris. Mémoires et documents Portugal 1, folio 86.

${ }^{43}$ Mémoire pour servir d'instruction au sieur O’Dune, allant a Lisbonne pour y résider em qualité de Ministre Plénipotentiaire du roi auprès du roi de Portugal. Versailles, 15 novembre 1761. Archives du ministère des affaires étrangères - Paris. Mémoires et documents - Portugal 1, minutes, folio 255.
} 
enviado francês, trabalho. Muito trabalho. Levava uma cópia do mémoire das negociações França-Inglaterra que recebera. Chegou a Madrid no dia 21 de dezembro. Com um atraso que não se sabe ao certo a razão. Despachou imediatamente com o rei Carlos e com o secretário Ricardo Wall. A tensão não era pequena. Não tinha mais como evitar. A Espanha entrara na guerra contra a Inglaterra. O’Dunne foi para a casa do enviado francês com quem conversou e conversou. O secretário Ricardo, por ordem de seu rei, mandou chamar o conde Fuentes, seu embaixador em Londres. Lord de Bristol, embaixador inglês em Madrid, fugiu. ${ }^{44}$

Em Lisboa, os receios do secretário Sebastião vinham se tornando realidade com as informações que iam chegando. Em fins de novembro, desde Londres, o conde de Egremont orientou Hay a não mais enviar papéis sigilosos para Madrid. Espanha, em sua visão, estava praticamente na guerra. Precisava apenas oficializar. Não tinha muito mais saídas. No mesmo correio, pedia para que o secretário Sebastião fosse informado. ${ }^{45}$ Esse correio chegou a Lisboa pelo dia 8 de dezembro. Nesse dia, Hay esteve com o secretário Sebastião sem a intermediação de Luiz da Cunha. Talvez tenha sido a primeira vez em que o consenso se instalara entre os dois a respeito da guerra. No dizer do secretário Sebastião, não tinha mais jeito. Era esperar o pior. ${ }^{46}$ Nas Américas, a desgraça já era total. Os espanhóis haviam amplificado as hostilidades na região do rio da Prata. O secretário Sebastião ordenara contraataque massivo. "Repel force with force", no dizer do inglês. Problema era que essa força estava enfraquecida ou inexistente. ${ }^{47} \mathrm{E}$ a sensação de impotência, por vez, os acometia. Mesmo tendo a Inglaterra nas costas. No caso do embaixador Hay, a impotência virou desespero quando perdeu contato com o enviado inglês em Madrid. Era 23 de dezembro. A notícia da entrada da Espanha na guerra ainda não tinha chego. Nem precisava. Fazia mais de duas semanas que Bristol não dava notícia. Isso preocupava ao secretário Sebastião também. ${ }^{48}$ Mas preocupações maiores recaíram sobre esse secretário do rei José. No dia 27 de dezembro, recebeu a nova desde a Espanha. Já passava do meio-dia. Imediatamente convocou um conselho com todos os ministros. Não se sabe se com os ingleses, ou pelo menos com Hay,

\footnotetext{
${ }^{44}$ Quadro elementar, op. cit., tomo 7, pp. 29-34.

${ }^{45}$ Earl of Egrement to E. Hay. Londres, 21 de novembro de 1761. The National Archives - Londres, State Paper Foreing - Portugal, 89/54.

${ }^{46}$ E. Hay to Earl of Egrement. Lisboa, 9 de dezembro de 1761. The National Archives - Londres, State Paper Foreing - Portugal, 89/54.

${ }^{47}$ E. Hay to Earl of Egrement. Lisboa, 23 de dezembro de 1761. The National Archives - Londres, State Paper Foreing - Portugal, 89/54.

${ }^{48}$ Id., ibid.
} 
também. Foi uma longa tarde-noite. Nela o secretário Sebastião fez o que jamais fizera nos últimos meses e ano. Foi à casa do embaixador espanhol. E mais de uma vez. ${ }^{49}$

${ }^{49}$ Quadro elementar, op. cit., tomo 7, p. 37. 


\section{Noite sem fim}

War! that mad game the world so loves to play.

Jonathan Swift $^{1}$

The peace must take account of the security of Portugal.

Conde de LippeBückeburg $^{2}$

Spain must make peace with Portugal before with Britain.

Rei George III $^{3}$

Agonia. Desespero. Aflição.

Tensão.

Raiva. Conspiração.

Desacorçoo.

Decisão.

Do dia 27 de dezembro de 1761 ao início de setembro de 1762, não foi outra a rotina na corte lusa. A guerra deixara de ser dos outros. Portugal poderia ser invadido a qualquer momento. Lisboa poderia ser tomada sem grande esforço. Sua capacidade de reação tendia ao nulo. Seus domínios corriam risco de diminuir em dimensão. Muito especialmente o espaço americano. Os franceses estavam prontos para invadir a Amazônia. Os espanhóis, preparados

\footnotetext{
${ }^{1}$ Ode to the honourable Sir William Temple. In.: The poetical words of Jonathan Swift. London: William Pickering, vol. 1, 1833 .

${ }^{2}$ Instructions from the King to the Duke of Bedford. St. James, 4 de setembro de 1762. The National Archives Londres, State Paper Foreing - France, 78/253, folio 7.

${ }^{3}$ Id., ibid.
} 
para tomar, dominar a região sul. Não houve dia em que o secretário Sebastião não recebeu ou procurou gente para tratar desses problemas. Os diplomatas ingleses viraram aliados decisivos. Sebastião e Edward Hay assumiram o hand by hand cotidiano. Cooperação absoluta. Não sem alguma desconfiança.

Naquela noite de 27 de dezembro de 1761, o conselho de ministros português se reuniu às pressas. Desde Madrid chegara a notícia da ofensiva espanhola contra a Inglaterra. Mesmo gentil e afável e bem intencionado, José Torrero, enviado del Prado em Lisboa, provavelmente não tinha informações privilegiadas. Sabia tanto quanto todos sobre que se passava. Do lado francês, Saint-Julien estava ainda menos informado. Praticamente todos os contatos em Madrid estavam inviabilizados. Desde a assinatura do pacto de família, o chanceler Choiseul diminuiu importantemente a substância de suas conversas com seus enviados em Lisboa e Madrid. Saint-Julien e d'Ossum. Ordenou que esses fizessem o mesmo. Entre eles. Madrid-Paris-Madrid-Lisboa-Paris-Lisboa-Madrid. O chanceler inglês tinha dado a mesma orientação para o embaixador Hay e ao lord Bristol, homem do rei George em Madrid. ${ }^{4}$ O secretário Ricardo Wall adotara o mesmo com os seus. Restava ao secretário Sebastião os espiões e a intuição. Embora tivesse muito - espiões e intuição -, preferiu a temperança.

No dia 31 de dezembro, depois de tido por desaparecido, lord Bristol chegou a Lisboa. O enviado espanhol em Londres fôra precavido da decisão da Espanha antes dela ser tomada. Portanto, teve tempo para preparar sua saída. Bristol, do contrário, recebeu a notícia como os demais. Por isso, saiu às carreiras da capital espanhola. Como que fugitivo e sem noticiar a ninguém. ${ }^{5}$ Reestabelecido em Lisboa, foi falar com o secretário Sebastião. Foi das poucas vezes que o nobre e, como diziam, fleumático secretário português pediu para falar com alguém. O objeto da conversa era claro: a situação na Espanha. Bristol tinha pouco a dizer. Ao menos, nada que interessasse ao secretário geral do rei José. A única quase novidade talvez tenham sido as intenções do enviado francês estacionado em Madrid. ${ }^{6} \mathrm{O}$ secretário Sebastião sabia das tramas do gabinete francês. Sabia do ideário "todos contra a Inglaterra". Jamais se

\footnotetext{
${ }^{4}$ E. Hay to Earl of Egremont. Lisboa, 23 de dezembro de 1761. The National Archives - Londres, State Paper Foreing - Portugal, 89/54.

${ }^{5}$ Id., ibid.

${ }^{6}$ Sir H. Frankland to Earl of Egrement. Lisboa, 15 de janeiro de 1762. The National Archives - Londres, State Paper Foreing - Portugal, 89/55.
} 
posicionara oficialmente. Entretanto, nesse momento de dúvidas, não desconsiderou saber mais. Ouviu e ouviu. ${ }^{7}$

Ouvir para agir.

No dia 5 de janeiro, o embaixador inglês em Lisboa, depois de ser dos primeiros a estar com Bristol e conversar longamente com ele, enviou o primeiro relatório sobre o poder de ação e ataque português. Consideração-síntese: "lamentável". Foi o qualificativo que utilizou para se referir à total desgraça do Portugal. Que, estruturalmente, ainda não tinha se recuperado da fúria do fogo e dos sons do sismo. Tinha poucos barcos de guerra. Pouca tropa. Pouco dinheiro. Nenhum crédito. Sua nobreza estava absolutamente descontente. ${ }^{8}$ Uma radiografia honesta. Nada novidadeira. Mas nem sempre reconhecida. Sabendo desse relatório de Edward Hay, o secretário Sebastião lhe instou a uma entrevista a sós. Queria uma retratação. Afirmava que a situação não era tão danosa assim. Pelo sim pelo não, a resposta de Londres foi pedindo um relatório, então, português sobre a situação. O objetivo era saber o que Portugal poderia fazer curto, médio prazo em caso de guerra. O secretário Sebastião respondeu com tenência que seu reino poderia suportar por três ou quatro meses uma eventual investida inimiga. Espanhola ou francesa. E passou mais de hora explicando sua estratégia. Hay não discutiu. Não contradisse. Mas denunciou ao seu superior - que agora era o conde de Egrement, pois William Pitt estava enfermo - haver, no mínimo, certa ingenuidade ou máfé da parte do luso secretário. Ou uma subavaliação da gravidade do estágio da guerra. Ou ainda e pior, a possibilidade de os homens do rei José estarem tombando para o lado francês querendo participar da família franco-espanhola. Na visão de Hay, o socorro naval e militar precisaria chegar imediatamente. Era imprescindível. Para não contrariar o secretário Sebastião, Hay sugeriu que o lord Tyrawly fosse incumbido do socorro. Tyrawly era conhecedor do português, língua, e dos portugueses, povo. Bem ambientando à corte. Bem relacionado com o rei José. Bem visto pelo secretário Sebastião. ${ }^{9}$ No dia 9 de fevereiro, Egremont respondeu a Hay e ao sir Frankland confirmando o envio de Tyrawly para chefe da armada e mediação de conflitos. ${ }^{10}$

\footnotetext{
${ }^{7}$ Id., ibid.

${ }^{8}$ Sir H. Frankland to Earl of Egrement. Lisboa, 5 de janeiro de 1762. The National Archives - Londres, State Paper Foreing - Portugal, 89/55.

${ }^{9}$ E. Hay to Earl of Egremont. Lisboa, 17 de janeiro de 1762. The National Archives - Londres, State Paper Foreing - Portugal, 89/55.

${ }^{10} \mathrm{Sir}$ H. Frankland to Earl of Egrement. Lisboa, 5 de janeiro de 1762. op. cit.
} 
No início de março, chegou todo mundo. Chegou Luiz da Cunha que estava em Madrid avaliando pessoalmente o andamento da guerra. Chegou Jacques O’Dunne, enviado francês, com a difícil tarefa de convencer os portugueses a mudarem de casaca. ${ }^{11}$ Chegou o lord Tyrawly com a esperança de aumentar as possibilidades de Portugal na guerra.

No dia 12 corrente, Tyrawly, Luiz da Cunha, o embaixador Hay e o secretário Sebastião estiveram reunidos durante quase o dia inteiro. Tyrawly queria saber das avaliações do gabinete português. Luiz da Cunha fez uma exposição do que se passava na Espanha. O movimento de tropa. A inteligência militar. Diversos segredos de estado. ${ }^{12} \mathrm{Em}$ seguida, o secretário Sebastião repetiu avaliação e sua exaltação da grandeza de Portugal em guerra e em paz. Reconheceu os riscos de uma invasão. Descreveu as condições de defesa. Sem comentar, Tyrawly e Hay se retiraram para tirar suas impressões em silêncio. Essas impressões foram enviadas em seguida para Londres. Da pena de Hay, mais do mesmo. ${ }^{13}$ Tyrawly foi mais direto e incisivo. Não praticou comedimentos. Afirmou que a dupla Sebastião-Luiz da Cunha era de lamentar. De chorar mesmo. Conheciam nada do assunto. Possuíam nula inteligência e nula coerência. Portugal, em sua ótica, precisava, para além de suporte naval e militar, de clareza estratégica. Essa clareza exigia inteligência. Inteligência, estocava, não havia entre aqueles lusos. $^{14}$

Durante sua passagem por Portugal, os comentários de Tyrawly foram todos nesse nível. Ásperos e sarcásticos. Meio exagerados. Meio realísticos. O secretário Sebastião não demorou a ficar sabendo. Obviamente não gostou nada. Entretanto, não alterou sua relação. No curso da guerra, a dissimulação virou regra entre eles.

Natural.

Um gênio da diplomacia em termos de guerra e em tempo de paz nos fins do século seguinte observaria de modo irreparável que "é melhor não saber como as salsichas são feitas".

Sim: melhor não saber.

\footnotetext{
${ }^{11}$ Quadro elementar das relações políticas e diplomáticas de Portugal com diversas potências do mundo desde o princípio da monarquia portuguesa até os nossos dias ordenado e composto pelo visconde de Santarém. Lisboa: Typ. da Academia Real das Sciencias, tomo 7, 1864. pp. 49-50.

${ }^{12}$ E. Hay to Earl of Egremont. Lisboa, 12 de março de 1762. The National Archives - Londres, State Paper Foreing - Portugal, 89/55.

${ }^{13}$ Id., ibid.

${ }^{14}$ Lord Tyrawly to Earl of Egremont. Lisboa, 12 de março de 1762. The National Archives - Londres, State Paper Foreing - Portugal, 89/55.
} 
No correr daquele mês de março, Torrero e O’Dunne iniciaram encontros oficiais com Luiz da Cunha com o objetivo único de convencê-lo a convencer sua corte a aderir ao pacto franco-espanhol. Luiz da Cunha serviu apenas de mediador. A discussão de fundo foi efetuada entre o secretário Sebastião e Tyrawly. O embaixador Hay, vez por outra, também participou do debate. $\mathrm{O}$ ultimato prometia não ataque a Portugal em caso de adesão. Sugeria mediação geral de todos eventuais problemas diplomáticos, políticos e econômicos que o rompimento da aliança luso-britânica pudesse ocasionar. E garantia vantagens econômicas e políticas a Portugal. ${ }^{15} \mathrm{O}$ secretário Sebastião avaliou a proposta e respondeu sempre sob o controle dos ingleses. Tyrawly, notando a importância do ultimato, reforçou a necessidade de apoio inglês. Em sua visão, os lusos poderiam fraquejar. O subentendido do texto ficou evidente para todos desde o primeiro momento. A negativa portuguesa seria o sinal verde para o ataque hispanofrancês. ${ }^{16} \mathrm{O}$ secretário Sebastião mandou dizer não. Mas cobrou uma conversa imediata com Hay. Foi pressionar os ingleses. Sabia, como todos, que a partir dali, a invasão era questão de dias, horas. A invasão, entenda-se, de Lisboa. Portugal estava em muito já visada. No imediatamente pós-assinatura do pacto de família, o enviado francês em Madrid persuadiu o governo espanhol a romper negócios com os portugueses. O comércio do trigo, dos mais importantes no balanço comercial para o lado luso, foi o primeiro. A segunda diretiva foi ocupar as fronteiras em gesto de intimidação. Enquanto Luiz da Cunha recebia o ultimato e o secretário Sebastião conferenciava com Hay e Tyrawly, o marquês de Sarria, oficial espanhol, invadia Miranda e tomava, sem esforço, Bragança e Moncorvo. Na sequência, adentrou Traz os Montes. Sua próxima parada seria o Porto. Vendo e sentindo a vontade e determinação desses espanhóis, o almirante inglês responsável pela área por pouco sucumbe e libera os seus para debandar. Mas em última hora, decidiu emboscar os homens de Sarria no Douro. Foi em Douro que os espanhóis afinaram e voltaram para Moncorvo. Mesmo assim, seguiram para Val de la Mula querendo chegar à Beira. O objetivo era, sobretudo, vingar seus homens abatidos no Douro. Sitiaram Almeida. Na sequência, forçaram a gente da Beira a se entregar. ${ }^{17}$

\footnotetext{
${ }^{15}$ E. Hay to Earl of Egremont. Lisboa, 22 de março de 1762. The National Archives - Londres, State Paper Foreing - Portugal, 89/55.

${ }^{16}$ Lord Tyrawly to Earl of Egremont. Lisboa, 22 de março de 1762. The National Archives - Londres, State Paper Foreing - Portugal, 89/55.

${ }^{17}$ Quadro elementar das relações políticas e diplomáticas de Portugal com diversas potências do mundo desde o princípio da monarquia portuguesa até os nossos dias ordenado e composto pelo visconde de Santarém. Lisboa: Typ. da Academia Real das Sciencias, tomo 18, 1864. pp. 377 ss.
} 


\section{Due to arrive}

A notícia do ultimato franco-espanhol chegou a Londres, primeiramente, pela pena de Tyrawley. E numa mensagem ao seu estilo. No dia 22 de março, esse lord inglês lamentava peremptoriamente a situação de Portugal. Em seu entender, pior que o assédio dos inimigos era a situação e organização dos lusos frente à guerra iminente. ${ }^{18}$ A Portuguese army era-lhe uma "multidão de barulhentos sem roupa, armas, comida e pagamento". ${ }^{19}$ Nada que dependia dos comandantes, dr. Sebastião e cia., funcionava. Os hospitais militares eram vergonhosos. Munição, não havia. A solução seria o envio imediato de uma força expedicionária como suporte. Pois, diante do ultimato, a fragilidade emocional dos lusos aumentava. ${ }^{20}$ Sabendo do parecer de Tyrawley, o embaixador português em Londres se apressou em pressionar ainda mais o governo inglês a liberar o suporte. No dia 8 de abril, no mesmo dia em que a carta de Tyrawley chegou, Martinho de Mello e Castro, homem de Lisboa em Londres, escreveu para Egremont reforçando a avaliação dos riscos. Disse ter o rei José mobilizado 31.400 homens e 9 navios de guerra, mas não era suficiente. British subsidy era imperativo. ${ }^{21}$ Antes de responder, Egremont foi ter com o rei George. Nesses últimos dias, ambos, Egremont e o rei George, despachavam sobre tudo e muitas vezes ao dia. Mas não necessariamente sobre os ibéricos. No dia 13 pela manhã, divulgou a posição real. Para Martinho de Mello relatou ter o rei ficado extremamente surpreso com a astúcia franco-espanhola. Disse estar a caminho ao menos 200.000 libras mais tropas, cavalos e assessórios. ${ }^{22}$ Essa era a estimativa. Mas que precisava passar pela house of commons, onde, em verdade, a ajuda estava empacada. No mesmo suspiro, solicitou a Hay que acalmasse Tyrawly que, ao que se percebia, estava certo, mas alterado. $^{23}$

Assim que soube dos avanços de Sarria, Martinho de Mello reescreveu a Egremont em tom de desespero. O mesmo desespero que, por certo, animava os espíritos da gente em Lisboa. O colapso de Portugal estava por dias, argumentava. British military precisava rumar para lá urgentemente. Egremont lamentava, mas tinha pouco a fazer que esperar a deliberação

\footnotetext{
${ }^{18}$ Lord Tyrawly to Earl of Egremont. Lisboa, 22 de março de 1762. The National Archives - Londres, State Paper Foreing - Portugal, 89/55, folio 82.

${ }^{19}$ Lord Tyrawly to Earl of Egremont. Lisboa, 29 de maio de 1762. The National Archives - Londres, State Paper Foreing - Portugal, 89/56.

${ }^{20}$ Lord Tyrawly to Earl of Egremont. Lisboa, 22 de março de 1762, op. cit.

${ }^{21}$ Martinho de Mello e Castro to Earl of Egremont. Londres, 8 de abril de 1762. The National Archives Londres, State Paper Foreing - Portugal, 89/55, folios 178-82.

${ }^{22}$ Earl of Egremont to Martinho de Mello e Castro. Londres, 13 de abril de 1762. The National Archives Londres, State Paper Foreing - Portugal, 89/55.

${ }^{23}$ Earl of Egremont to E. Hay. Londres, 13 de abril de 1762. The National Archives - Londres, State Paper Foreing - Portugal, 89/55, folios 174-200.
} 
do parlamento. Nesses dias, segunda quinzena daquele mês, chegou a notícia do segundo ultimato franco-espanhol. A ideia de Martinho de Mello para pressionar ainda mais os lords foi mandar, com a permissão de Egremont, publicar os ultimatos na London Gazette. Tal e qual se fez. ${ }^{24}$ Ao mesmo tempo, não menos desesperados, o embaixador Hay e os secretário Sebastião e Luiz da Cunha e o rei José discutiam fervorosamente que fazer. Partiu de Hay a ideia de influenciar os parlamentares com seu depoimento de campo. De alguém que conhecia perfeita e profundamente as razões do impasse. Não era nova para ninguém que a resistência dos homens de Londres estava relacionada às dificuldades impostas aos ingleses em terras portuguesas. A carta de Hay, dirigida ao rei George e aos parlamentares, argumentava que "any military assistance given to Portugal at this time, will have its proper weight in all our comercial negotiations for the future, and the more effectual, the more it will operate in this respect." 25 Ciente dessa diretiva, no fundo lusa, expressa nas palavras de Hay, o rei Geoge mandou participar as autoridades em Lisboa da sua mais profunda admiração por tal coragem. ${ }^{26}$ Sob esse furor, a house of commons declinou: aprovou o apoio.

Tyrawly

Mesmo com a liberação e o envio do suporte, o descontentamento de Tyrawly com os homens do rei José era progressivo. Dias imediatamente depois da carta do embaixador Hay ao rei George, Tyrawly escreveu também. Reforçou ser impossível comandar qualquer tipo de força em terras lusitanas, "due to the bad state of Portuguese army", e pediu a permissão de sua alteza para se demitir. Tyrawly gozava de grande respeito e admiração em Londres. Era dos poucos enviados que falava e escrevia português como língua materna. Tinha passe livre nas altas rodas de Lisboa e de Belém. Conversava francamente com todos. Independente da patente. Aos 76 anos, tinha sido próximo do finado rei João. Isso lhe conferia ainda mais respeitabilidade diante do rei José e súditos. Menos do secretário Sebastião que passou a simplesmente não mais lhe aturar. E a cizânia era de mão dupla. $\mathrm{O}$ rei inglês custou a dar retorno que veio em meados de junho. Em carta do dia 15, remetida por Egremont, Tyrawly

\footnotetext{
${ }^{24}$ Martinho de Mello e Castro to Earl of Egremont. Londres, 28 de abril de 1762. The National Archives Londres, State Paper Foreing - Portugal, 89/55, folios 208-13. Martinho de Mello e Castro to Earl of Egremont. Londres, 3 de maio de 1762. The National Archives - Londres, State Paper Foreing - Portugal, $89 / 55$.

${ }^{25}$ E. Hay to Earl of Egremont. Lisboa, 27 de abril de 1762. The National Archives - Londres, State Paper Foreing - Portugal, 89/55, folio 280.

${ }^{26}$ Earl of Egremont to E. Hay. Londres, 18 de maio de 1762. The National Archives - Londres, State Paper Foreing - Portugal, 89/56.
} 
era solicitado a aguardar os substitutos. Sim: dois. O lord Loudoun para substituí-lo no comando do exército inglês e o conde de Lippe-Bückeburg para liderar a Portuguese army. Muito em breve, seriam três. O príncipe Mecklembourg Strelitz, the queen's brother, se juntaria ao conde de Lippe. ${ }^{27}$ Tyrawly não estava disposto a esperar ninguém. "I have taken an insurmountable disgust to the country, and therefore the more unfit to act with them", respondeu ao rei George logo na primeira oportunidade. ${ }^{28}$ Mesmo assim, esperou. Não muito. Só um pouco. Loudoun estava para chegar via Belle Isle. Lippe e Strelitz já estavam com as malas prontas e fechadas. Vendo que nunca chegavam, se retirou a Cintra. De Cintra volveu a Lisboa somente no dia 8 de agosto, momento da chegada de Loudoun. ${ }^{29}$

Sabendo da presença de Tyrawley, o vice-consul inglês em Lisboa promoveu um jantar de boas vindas e até mais. Tyrawley voltaria para Londres logo em seguida. Entre os convivas, havia somente ingleses. Dentre os quais, o embaixador Hay. Regados a vinhos, os convidados entraram a discutir a conjuntura. Discussão acalorada e tensa. Cada qual expunha sua convicção com desmedida emoção. Pelas tantas, Tyrawley acusou os ingleses de traição. Disse estar a Inglaterra vendida. E que Hay era um dos fiadores dessa deslealdade. Insultado, o cortês enviado inglês maior, pediu ao lord modos. Tyrawley, do contrário, insistiu em sua acusação. Hay e os demais, surpresos, ensaiaram engrossar exigindo respeito. Foi quando Tyrawley foi em direção de Hay para afirmar sua afirmação. O embaixador foi apanhado pela casaca e chacoalhado e esbofeteado. Sem a intervenção dos presentes, Tyrawley iria machucá-lo de verdade. O jantar foi dado por encerrado e Tyrawley, por completamente demente. ${ }^{30}$ Seu encontro com Loudoun e com o rei José seria na manhã seguinte. O secretário Sebastião foi participado do ocorrido na casa do vice-cônsul. Foi apenas mais um artifício para reconhecer Tyrawley por louco e, portanto, interlocutor não frequentável. Seu retorno a Londres foi antecipado o mais que se pôde. E a recomendação dupla, do secretario português e do embaixador inglês, foi que fosse enviado diretamente para um hospício.

Ambos devem de ter concordado, como concordamos, em silêncio com a máxima que adverte que canalhas e cretinos e covardes também envelhecem.

\footnotetext{
${ }^{27}$ Earl of Egremont to Lord Tyrawly. Londres, 15 de junho de 1762. The National Archives - Londres, State Paper Foreing - Portugal, 89/56, folio 19.

${ }^{28}$ Lord Tyrawly to Earl of Egremont. Lisboa, 26 de junho de 1762. The National Archives - Londres, State Paper Foreing - Portugal, 89/56.

${ }^{29}$ Quadro elementar das relações políticas e diplomáticas de Portugal com diversas potências do mundo desde o princípio da monarquia portuguesa até os nossos dias ordenado e composto pelo visconde de Santarém. Lisboa: Typ. da Academia Real das Sciencias, tomo 7, 1864. pp. 75 ss.

${ }^{30}$ Id., ibid.
} 


\section{Destinos}

Antes do nobre lord inglês e do correio de lamentações chegarem a terras britânicas, Egremont mandou novas de Londres. No dia 7 de setembro, com imenso entusiasmo, escreveu para Hay informando o "Franco-British agreement" para se discutir os termos da paz. O processo, em verdade, estava em andamento e adiantado. O palco das negociações era Paris-Versailles-Fontainebleu. O duque de Bedford, que nutria relações civilizadas com os diplomatas franceses, fôra nomeado negociador. A instrução do rei George sugeria ênfase na inclusão ativa e positiva de Portugal na discussão. As demandas lusas já haviam sido solicitadas ao embaixador português em Londres e inseridas na pauta da primeira reunião Bedford-Choiseul. A pedra angular do trato anglo-luso firmava que nenhum armistício seria assinado "without including Portugal and evacuation of all territory taken by France and Spaniards". Nada disso era ainda do conhecimento dos homens do rei José. Martinho de Mello e Castro e Egremont trabalhavam também hand by hand no segredo e na discrição. Nada fôra precipitado. Lisboa soube de tudo no mesmo instante. Setembro já entrado. Dali em diante, o processo ganhou novo rumo e ritmo e velocidade. O rei George mandou solicitar ao secretário Sebastião pressa. Inexistia voz lusitana em Paris. Ou bem se nomeava negociador da parte do rei José ou bem que se atribuísse a Bedford "full powers to do so". Tudo para logo. A corte de Londres não queria sofrer atrasos ou obstruções desnecessários. ${ }^{31}$ Participados, o secretário Sebastião e o rei José respiraram aliviados. O rei José mandou agradecer ao rei George. Desespero queria quase nada mais dizer diante da horrenda situação naquela parte da Ibéria. Surgia alguma alvorada naquela noite que, desde dezembro passado, parecia sem fim. Mas a satisfação nem de longe estava perto do fecho. O rei de Portugal ficou desapontado por seu homólogo não tê-lo mantido seguidamente informado. Entendeu, muito influenciado por seu secretário Sebastião, desrespeitoso. Monarcas aliados não deveriam segredar entre si. Sobretudo em se tratando de assunto tão capital. ${ }^{32}$

No dia 18, ainda de setembro, o rei José nomeou Martinho de Mello seu procurador em Paris. Nenhuma surpresa. No dia 13 de outubro, escreveu para o rei francês informando e apresentando seu enviado. No dizer do soberano português, era tempo de renovar a "antiga amizade" que sempre subsistira entre os dois reinos, povos e coroas. ${ }^{33}$ Entretanto, essa

\footnotetext{
${ }^{31}$ Earl of Egremont to E. Hay. Londres, 7 de setembro 1762. The National Archives - Londres, State Paper Foreing - Portugal, 89/57.

${ }^{32}$ Martinho de Mello e Castro to Earl of Egremont. Londres, 9 de outubro 1762. The National Archives Londres, State Paper Foreing - Portugal, 89/57.

${ }^{33}$ Quadro elementar, op. cit., tomo 7, p. 80-1.
} 
decisão não fôra simples nem fácil. No dizer de Hay, dúvidas e hesitações e observações críticas tomaram conta. O secretário Sebastião estivera reticente diante das preliminares da negociação. Não perdoava a indiferença - a bem dizer, frigidez - do rei George e do chanceler Egremont. O fato novo foi a anexação de pauta bilateral entre os ibéricos para renegociação do trato del Prado de 1761 que suspendera o tratado de Madrid de 1750. Hay nada disse. Apenas passou o informe para Londres. ${ }^{34}$ Londres ficou em silêncio até saber que o rei José havia retomado diálogo com a gente de Madrid e com a mãe do rei Carlos, dona Isabel Farnésio. Egremont mandou redobrar a atenção sobre eles. O conflito luso-espanhol continuava. Não por vontade. Por desinformação. Tropas dos dois lados ainda seguiam em campo. Nem todos tinham sido informados do início da resignação coletiva. Nem o secretário Sebastião nem o secretário Ricardo Wall tinha batuta para trazer seus recrutas para caserna. Tinham frieza. Mas não tanto sangue frio. Para Lisboa e Madrid, Paris parecia, mais ainda nesses dias, muito longe. Só a apreensão cevava a missão. Não era covarde titubear. O receio deles era a guerra não terminar. O receio de Londres era, por conta deles, a guerra continuar. Na passada de outubro a novembro, Hay acalmou Londres. Descobriu, por informantes, que o objetivo do rei José era apenas avivar relação fora do eixo britânico. ${ }^{35} \mathrm{O}$ fim da guerra era inevitável. Estava due to. Como bem sabia e sentia o rei de Portugal, os reinos, na Europa e fora dela, eram constrangidos pela geografia. Mantinham vizinhança incontestável. E não mudariam de endereço tão logo. Talvez jamais. Boa relação em tempo de paz era ainda mais importante que em tempo de guerra. Mas só os cables de 8 e 9 de novembro serenaram os homens de Londres. Foi neles que Hay informou dos últimos detalhes das últimas operações militares em solo português invadido.

As autoridades portuguesas estavam absolutamente satisfeitas com Lippe. Para eles, comentou Hay, o "behaviour of Count Lippe and British troops who have saved Portugal". 36 Strelitz, em revanche, passou doente por toda a operação e estava convalescendo em Lisboa. Em uníssono se propalava vitória. Mas os números nos campos não eram animadores. Soldados por Portugal e por Espanha padeciam enfermidades. Ao menos 1.500 homens da parte do rei Carlos estavam hospitalizados. Mais ou menos a mesma quantia desertou por fome, sede, frio ou banzo. Não se tem os números para os batalhadores do rei José. Mas não

\footnotetext{
${ }^{34}$ E. Hay to Earl of Egremont. Lisboa, 14 de outubro de 1762. The National Archives - Londres, State Paper Foreing - Portugal, 89/57.

${ }^{35}$ E. Hay to Earl of Egremont. Lisboa, 15 de outubro de 1762. The National Archives - Londres, State Paper Foreing - Portugal, 89/57.

${ }^{36}$ E. Hay to Earl of Egremont. Lisboa, 8 de novembro de 1762. The National Archives - Londres, State Paper Foreing - Portugal, 89/57.
} 
deve de ter tido dimensões muito diferentes. ${ }^{37}$ Egremont sentia conforto nessas, mesmo que trágicas, novas. Enquanto isso em Paris, Martinho de Mello só fazia se queixar. Estava convencido que França e Espanha tramavam contra Portugal. Fariam de tudo para pô-lo em posição inferior. Por isso, clamava ato contínuo intervenção do rei George, de Egremont, de Bedford, de anjos, de deus. ${ }^{38}$ No fim de dezembro, foi falar diretamente com o árbitro francês. Disse ao chanceler Choiseul, o primo, ser inadmissível que o enviado espanhol, Grimaldi, além de fazer corpo mole não desse resposta plausível para fazer avançar a discussão em torno das terras surripiadas do rei José. ${ }^{39}$

Com custo, o acordo se pactou. A paz de Paris veio no fevereiro de 1763. Certa calmaria foi imposta às metrópoles. Restava agora juntar os cacos duma Europa cujo destino passou a ser travado fora dela.

\footnotetext{
${ }^{37}$ Id., ibid. E. Hay to Earl of Egremont. Lisboa, 9 de novembro de 1762. The National Archives - Londres, State Paper Foreing - Portugal, 89/57.

${ }^{38}$ Martinho de Mello e Castro to Earl of Egremont. Londres, 9 de dezembro 1762. The National Archives Londres, State Paper Foreing - Portugal, 89/57.

${ }^{39}$ Quadro elementar, op. cit., vol. 7, p. 81.
} 
Parte III

Os sentidos da capital 


\section{Cidades}

Toute ville un peu importante, surtout si elle est ouverte sur la mer, est une 'Arche de Noé', une vraie foire de masques', 'une tour de Babel'.

Fernand Braudel, Civilisation materielle, v. 3, p. 24 .

O ouro e os diamantes, então, fizeram perder o resto da cabeça e bom-senso que sobravam à metrópole.

Caio Prado Jr., Formação do Brasil Contemporâneo, p. 343.

Hoy, todo intelectual honesto está necesitado de un análisis y recuento de su actitud, y los historiadores no son una excepción. No podemos vivir en la sociedade nueva com las viejas concepciones históricas.

Manuel Moreno Fraginals, La historia como arma, p.11.

São Salvador da Bahia de Todos os Santos, a cidade da Bahia, foi, por mais de duzentos anos, a cidade do Brasil. De 1549 a 1763, foi o núcleo administrativo do império português nas Américas. Foi central e capital. Estratégica. Essencial para a organização e estruturação da colônia. Sede do governo geral, da provedoria, da ouvidoria. Sede do bispado, a partir de 1551. Do arcebispado, depois 1676. Praça de ordens religiosas. Colégios, mosteiros, conventos. Jesuítas, franciscanos, beneditinos, carmelitas, ordem das Clarissas primeiro convento fundado em 1677. Tinha diversas irmandades religiosas. Pujante Santa Casa de Misericórdia. Importante Senado da Câmara. Imprescindível alfândega. Múltiplas 
fortificações. Armazéns e igrejas. Muitas igrejas. Gente. Muita gente. De todo tipo. De muita origem. De plurais interesses. "Era uma cidade de burocratas e estivadores, mercadores e prostitutas". ${ }^{1}$ Pelos idos de 1587, tinha aproximadamente 4 mil almas sem contar escravos. Em 1724, quase 25 mil, contando-lhes. Para o fim daquele século, mais de 50 mil. Uma vila densa, complexa, agitada. Rica e de gente rica e desgraçadamente pobre. Movimentada e em movimento. Opulenta. Opressiva. Para alguns, livre. Uma verdadeiro espaço planetário ${ }^{2}$ que seguia le temps du monde. Cheia de senhores "enfatiotados, cadeirinhas de arruar, tanger de sinos, jogadas financeiras, candeias de azeite, tavernas tumultuadas, discursos bacharelescos, soldados insolentes, batuques de negros, batinas apressadas e mulatas seminuas". ${ }^{3}$ E por tudo isso, não demorou a se tornar objeto de cobiça, disputa, tocaia. Corsários franceses namoraram sua a baía em 1520. Piratas ingleses atacaram navios mercantes na região em 1586. Depois, os holandeses. Navios com sua bandeira ficaram mais de dois meses em 1599 emboscando passantes. Esse era apenas o prenúncio. Prelúdio da ciranda de intimidações. No julho de 1604, sob a liderança do almirante Paulus van Caarden, sete navios holandeses tomaram a baía e miraram 142 canhões engatilhados para a cidade da Bahia. Van Caarden era, sim, o conhecido "assombro dos mares". Adorava intimidar e maltratar inimigos. Em 1614, voltaram os franceses. Pilharam alguns comerciantes e se foram embora. Em 1624 e 27, voltaram os holandeses. Dessa vez, barbarizaram. Saquearam. Caçaram moradores. Violaram moças e mocinhas lindas e cheirosas. Em 1634 e 1648, vieram again. Invadiram territórios. Queimaram engenhos. Hostilizaram inocentes. Tararam donzelas. ${ }^{4}$ E assim seguidamente.

Quanto mais a cidade progredia, mais necessitava proteção. Administração. Atenção.

Grandiosa e altaneira, mas não isolada. Era o núcleo de capitania. Mais uma nesse oceano luso na América. Existia Pernambuco, existia o Rio de Janeiro. Em seguida, Sacramento. Depois São Paulo, as vilas das minas, Goiás. Depois o sul como um todo - Rio Grande de São Pedro e ilha de Santa Catarina e Sacramento. Depois o norte inteiro - GrãoPará e Maranhão. O dinamismo português era espetacular. Mesmo que caranguejando, expandia a convicção e a ocupação no mundo novo. Os desafios eram imensos no interior daquele território ermo e silencioso e sombrio. Pouco a pouco, tudo foi se amoldando. $\mathrm{O}$ mosaico foi se modelando. Gente foi se identificando. Identidades foram se formando.

\footnotetext{
${ }^{1}$ Stuart SCHWARTZ - Segredos internos: Engenhos e escravos na sociedade colonial, 1550-1835. São Paulo: Companhia das Letras, 2000. p. 80.

${ }^{2}$ Katia MATTOSO - Bahia, século XIX: uma província no Império. Rio de Janeiro: Nova Fronteira, 1992.

${ }^{3}$ Antonio RISÉRIO - A utopia brasileira e os movimentos negros. São Paulo: 34, 2007. p. 237.

${ }^{4}$ Hernâni DONATO - Dicionário das batalhas brasileiras. São Paulo: Ibrasa, 1996. p. 482. Stuart SCHWARZ Segredos internos, op. cit., p. 78.
} 


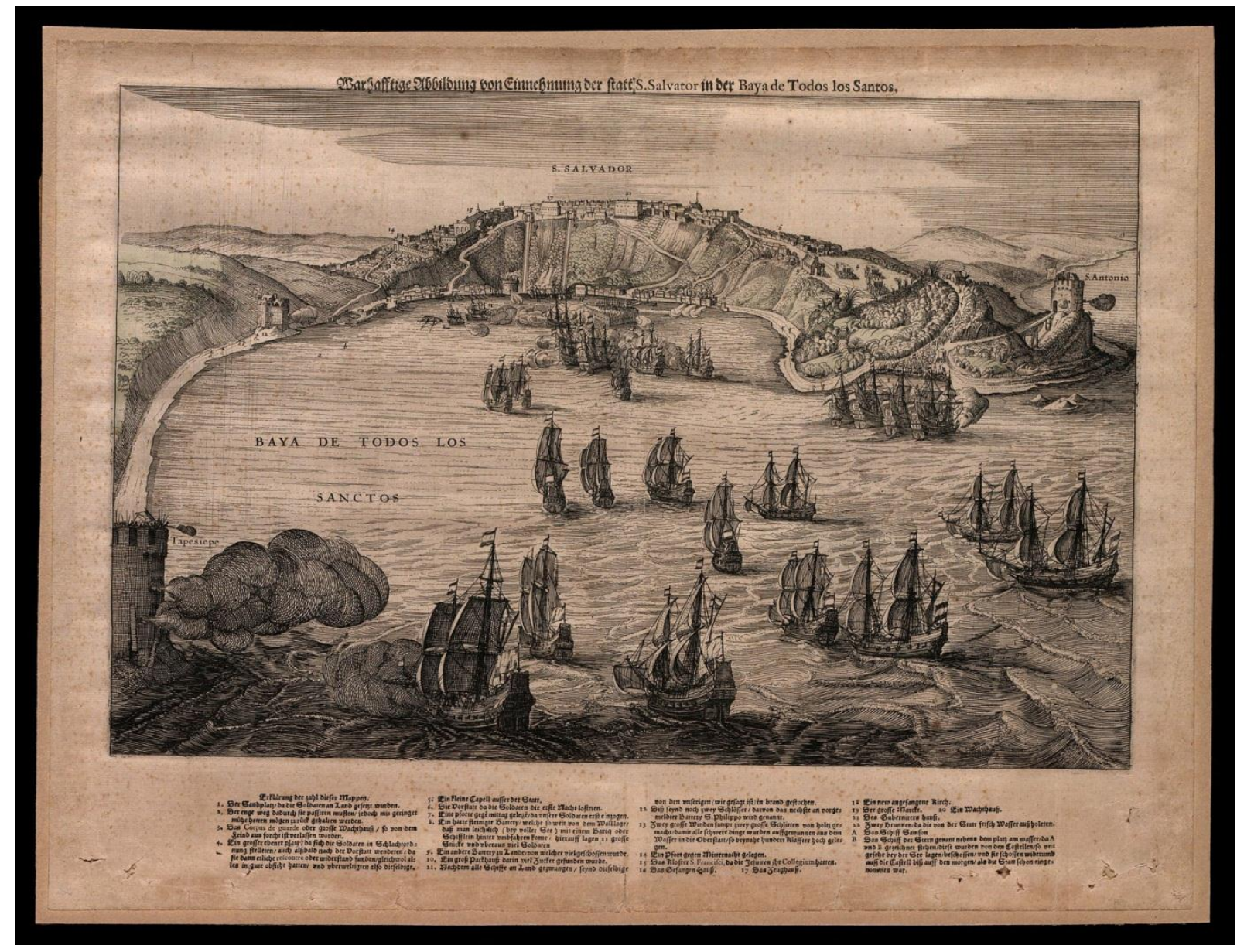

Com a pluralização das grandezas e das importâncias, a cidade-Bahia-capital foi ganhando concorrentes no interior do seu próprio domínio colonial. Ainda nos quinhentos, em 1570, o governador geral Luiz de Brito de Almeida equiparou o Rio de Janeiro à Bahia. Reivindicou e afirmou a força e o reconhecimento do Rio como o guardião de tudo que estava ao sul. ${ }^{5}$ Assim foi. Razão razoável. O sul vinha progressivamente se transformando num grande e grave problema. Os conflitos eram constantes. O tratado de Tordesilhas não passava de simulacro. Ninguém aceitava. Ninguém respeitava. Eram linhas. Imaginárias linhas. Ilusórias marcações. Nada mais. Sem gente, as fronteiras eram porosas. Movediças. Os lugares precisavam de pessoas de carne e osso. Muita vez, de arma na mão. A união ibérica fez um pouco se esquecer tudo isso. Depois dela, só aumentou o problema, a confusão.

O pós-restauração, pós-1640, operou na manutenção da independência e no estabelecimento de boas relações diplomáticas de Portugal. Incluso com Espanha, França e

\footnotetext{
5 Conde de Campo BELO - Governadores gerais e vice-reis do Brasil. Lisboa: Divisão de biblioteca e publicações, 1935. p. 127.
} 
Holanda que muito lhe preocuparam. A criação do conselho ultramarino, 1643, seguia essa meta. O conselho centralizou as relações com as colônias. Sobretudo a administração da americana. Salvador de Sá, governador do Rio de Janeiro, solicitou ao rei João IV, quase que desesperadamente, o povoamento do Rio de Janeiro até o rio da Prata. Em 1676 foi criado o bispado do Rio de Janeiro para tomar conta espiritual da região. Em 1680, finalmente, a colônia de Sacramento dependente do Rio de Janeiro. Que lhe administrava a burocracia, o comércio e o exército. ${ }^{6}$

O avanço dos paulistas, a descoberta de ouro, a concorrência do açúcar baianopernambucano com o antilhano, as disputas diplomáticas sobre Sacramento fizeram a cidade do Rio de Janeiro adentrar os setecentos com grande ar de prosperidade e responsabilidade. Administrar foi ficando mais complicado. A cidade se movia. A capitania se expandia. As jurisdições intentavam fugir.

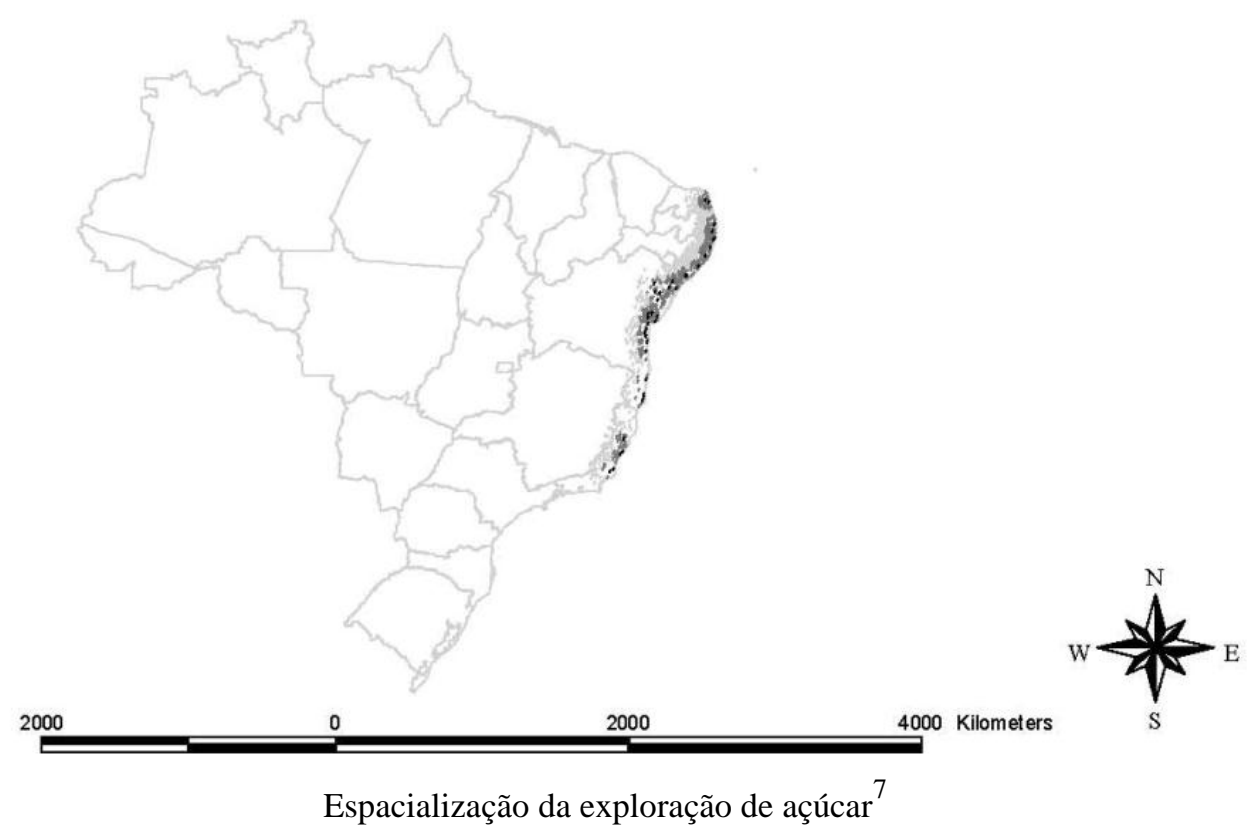

Nessa sequência de aumento de responsabilidade e importância do Rio de Janeiro, quem olha no conjunto e no isolado não resiste a retrospectivamente imaginar e conjecturar: vai ser capital, vai ser capital. Até que em 1763, veio a ser capital. A partir de 1808, virou capital. Na belle époque, irradiante capital. Desde Brasília, símbolo. Símbolo de uma cidade

\footnotetext{
${ }^{6}$ Pedro Octávio Carneiro da CUNHA - Política e administração de 1640 a 1763. In.: Sérgio Buarque de HOLANDA - História da civilização brasileira. 1. A época colonial. 2. Administração, economia e sociedade. Rio de Janeiro: Bertrand Brasil, 1997. pp. 13-7.

${ }^{7}$ Joana NARITOMI - Herança colonial, instituições \& desenvolvimento. Um estudo sobre a desigualdade entre os municípios brasileiros. Rio de Janeiro, 2007. (Dissertação apresentada ao departamento de Economia da PUC-RIO), p. 86.
} 
que se recusa voltar à vala comum dos espaços. ${ }^{8}$ Nesse sentido, a cidade-Rio de Janeirocapital tem sido vista como destino e tragédia. A obviedade de sua condição de capital transpassa a maioria das análises. O sentimento de ter deixado de ser, com a construção de Brasília, conjuga frustração, decepção e ressentimento. O imaginário carioca-fluminense acredita e afirma que o Rio de Janeiro continua sendo. ${ }^{9}$ E, muito pior que isso, vem fazendo de tudo para persuadir a todos que continua mesmo sendo.

Essa obsessão de cidade-capital impõe um impasse metodológico delicado. Especialmente quando o interesse se volta às razões da oficialização da cidade-Rio de Janeirocapital em 1763. Os rastros são poucos. Restaram o ofício-nomeação do secretário Sebastião de 8 de julho de 1763 e o ofício-retratação do governador Bobadela de 26 de março de $1762 .{ }^{10}$ Todo o mais não passa de especulação.

\section{Terra desolada}

Com ou sem documentação, toda narração depende de especulação. Verdade não passa de convenção. Uma relação de forças mediada por prova e convencimento, discurso e interpretação. Busca eterna de razão. Guerra sem fim. ${ }^{11}$

Maria Fernanda Bicalho e Marly Silva da Motta vêm sendo, salve melhor juízo, as pioneiras a chamar a atenção para a necessidade de discussão mais aprofundada sobre o Rio de Janeiro cidade-capital. Marly da Motta repousa sua abordagem sobre o impacto da perda da capital-Rio de Janeiro com a construção de Brasília para a "memória de capitalidade" da gente do Rio de Janeiro. Ou seja, chama a atenção para a dificuldade do carioca em

\footnotetext{
${ }^{8}$ Marly Silva da MOTTA - Que será do Rio? Refletindo sobre a identidade política da cidade do Rio de Janeiro. Tempo, Rio de Janeiro, vol. 4, pp. 146-174, 1997.

${ }^{9}$ Marly Silva da MOTTA - O Rio de Janeiro continua sendo? Rio de Janeiro: CPDOC , 2000.

${ }^{10}$ AHU - Rio de Janeiro, cx. 72, doc. 22. AHU - Rio de Janeiro, cx. 70, docs. 28, 29, 40 e 65; Brasil Limites, cx. 2, doc. 125.

${ }^{11}$ O debate é hipersensível no campo das ciências humanas e da filosofia. Alguma amostra da discussão pode ser encontrada em Paul RICOEUR - Temps et récit. Paris: Seuil, 1985. Roger CHARTIER - Au bord de la falaise. L'histoire entre certitudes et inquiétude. Paris: Albin Michel, 1998. Roger CHARTIER - Cardenio entre Ceravantes et Shakespeare. Histoire d'une pièce perdue. Paris: Gallimard, 2001. Carlo GINZBURG Mitos, emblemas, sinais. Morfologia e história. São Paulo: Companhia das Letras, 1998. Carlo GINZBURG Olhos de madeira. Nove reflexões sobre a distância. São Paulo: Companhia das Letras, 2005. Edward W. SAID - Culture and imperialism. New York: Alfred Knopf, 1994. Gianni VATTIMO \& P. A. ROVATTI - Il pensiero debole. Milano: Feltrinelli, 1983. Gianni VATTIMO - La fine dela modernità. Milano: Garzanti, 1985.
} 
reconhecer que o passado passou. ${ }^{12} \mathrm{O}$ foco de Maria Fernanda tem recaído sobre o enquadramento do Rio de Janeiro que ganha a capital no meio dos setecentos. Seu argumento essencial tem sido a noção de "capitalidade" na política do secretário Sebastião. ${ }^{13}$

O diálogo adiante será mais com Maria Fernanda que com Marly da Motta. Mas antes, convém explicitar que o elemento que as une creio ser o termo-conceito-argumento-jargão "capitalidade".

Marly da Motta se filia ao conceito por intermédio de L'Europe des capitales de Giulio Argan. Maria Fernanda, por "Goa É a Chave de Toda a Índia” de Catarina Madeira Santos. Argan e Madeira Santos navegam no alvorecer da época moderna. Quinhentos e seiscentos. Mesmo em realidades históricas quase contrastantes que eram Europa e Índia, seu diagnóstico converge. Ou seja, grosso modo, quando a cidade alcança grau espetacular de equipagem militar e organização cultural e importância política e ascensão econômica, não tem jeito: vira capital. Foi o caso de Goa, como enfatiza Madeira Santos. Foi o caso das principais capitais da Europa, como enfatiza Argan. ${ }^{14}$ A diferença entre eles - Marly da Motta-Giulio Argan e Maria Fernanda-Catarina Santos - reside na temporalidade e na historicidade. A “capitalidade” do Rio de Janeiro em Marly da Motta se exprime na memória de uma cidade que quer para sempre unir, unificar e sintetizar a nação e o país. Uma cidade, e população, que não admite não ser capital. Em Maria Fernanda, o oposto. O Rio de Janeiro aparece como cidade que quer viver a experiência de ser capital.

"Goa É a Chave de Toda a Índia” de Catarina Madeira Santos, saído em 1996 na Universidade Nova de Lisboa e publicado em 1999 em espaço português, recebeu muito favorável recepção no meio universitário especializado. Cobriu lacuna importante no estudo desse espaço da expansão portuguesa nos quinhentos. Com imensa sensibilidade no trato de fontes e conceitos, iluminou a compreensão do funcionamento do sistema político do império luso com menção ao caráter fragmentado e autônomo que poderia adquirir. Caso de Goa,

\footnotetext{
${ }^{12}$ Marly Silva da MOTTA - O Rio de Janeiro continua sendo: de cidade-capital a estado da Guanabara. Niterói: ICHF-UFF, 1997.

${ }^{13}$ Maria Fernanda BICALHO - As noções de capitalidade no Rio de Janeiro sob a política pombalina. In.: Ana Cristina ARAÚJO; José Luis CARDOSO; Nuno Gonçalves MONTEIRO et all. (Org.). O terremoto de 1755: impactos históricos. Lisboa: Livros Horizonte, 2007. Maria Fernanda BICALHO - O Rio de Janeiro no século XVIII: A transferência da capital e a construção do território centro-sul da América portuguesa. (mimeo)

${ }^{14}$ Giulio ARGAN - L'Europe des capitales. Genebra: Albert Skira, 1984. Catarina Madeira SANTOS - "Goa É a Chave de Toda a Índia". Perfil Político da Capital do Estado da Índia (1505-1570). Lisboa, CNCDP, 1999.
} 
estado da Índia. A porção americana do império português não era a Índia. O século XVIII não era o XVI. O Rio de Janeiro não era Goa. Sabendo amplamente disso, Maria Fernanda não ensaia nenhum tipo de comparação. Apenas extrai de Catarina Madeira o conceito e a inspiração. Seu objetivo, ao menos em seus escritos que tive acesso e se bem os entendo, vem sendo historicizar a "construção da centralidade - ou capitalidade - da cidade do Rio de Janeiro" "a partir da segunda metade do século XVIII". ${ }^{15}$ E o faz com perícia. Fugindo dos lugares-comuns de quase tudo que se escreveu sobre o assunto, a autora do belo A cidade e o império atacou com as preliminares da decisão do secretário Sebastião. Abordou em três atos, em sua ótica, definidores. $\mathrm{O}$ aumento da ameaça estrangeira aos portos do Rio de Janeiro. $\mathrm{O}$ fim repentino da missão do governador Gomes Freire de Andrade, o conde de Bobadela, na negociação Sacramento para retornar ao Rio de Janeiro. A recusa do mesmo governador Bobadela em ser vice-rei na Bahia.

Raciocínio lógico, poderoso e documentado.

A primeira prova descansa sobre a centena de canhões de uma fragata francesa que se posicionou sobre a barra do Rio de Janeiro em julho de 1757. Comandados pelo conde de Arché, os seis navios inimigos desproporcionalmente bem armados evidenciaram a fragilidade do sistema de segurança da cidade do Rio de Janeiro. "Terror e pânico" tomaram conta. Sabendo do incidente, menciona Maria Fernanda, o secretário Sebastião teria enviado ofício secretíssimo ao chanceler da relação do Rio de Janeiro ordenando que "sugerisse às câmaras de todas as vilas e cidades da capitania do Rio de Janeiro que escrevessem a Gomes Freire, pedindo-lhe que voltasse imediatamente à cidade, por ficarem seus moradores, em sua ausência, indefesos diante da incessante 'audácia' dos franceses”. E o governador Bobadela, insiste Maria Fernanda, passou imediatamente ao Rio de Janeiro após ordem direta do secretário do rei José. Toda essa movimentação de ofícios, sugestões e ordens, sustenta Maria Fernanda, ocorreu em $1758 .{ }^{16}$ Por fim, a derradeira evidência, sempre seguindo Maria Fernanda, advém da resposta do governador Bobadela recusando a condição de vice-rei sob o artifício de que não poderia deixar o "empório do Brasil" "sem cabeça". Quando, anos depois, finalmente a capital do estado do Brasil chegou, esclarece Maria Fernanda, não foi mais que o aspecto natural do "caráter central que a cidade vinha assumindo como cabeça e locus

\footnotetext{
${ }^{15}$ Maria Fernanda BICALHO - As noções de capitalidade no Rio de Janeiro sob a política pombalina, op. cit., pp. 258, 259.

${ }^{16} I d .$, p. 262.
} 
articulador das fronteiras territoriais e atlânticas de toda a vasta região centro-sul da América portuguesa." 17

Embora o arremate retome o lugar-comum da obsessão do Rio de Janeiro cidadecapital, o núcleo do argumento de Maria Fernanda inova. Sobretudo onde põe história.

$\mathrm{O}$ incidente das fragatas francesas intimidando os moradores dessa inegável importante cidade do império português que era o Rio de Janeiro certamente deve ter ressoado no gabinete do secretário Sebastião em Lisboa. Não consultei a documentação específica sobre o ocorrido. Conseguintemente, não vi o ofício do nobre secretário geral do rei José ao chanceler da relação do Rio de Janeiro que Maria Fernanda refere. Mesmo assim, fui persuadido. Acredito, pelo que ela, Maria Fernanda, conta, que o acontecimento operou fortemente no retorno do governador Bobadela ao Rio de Janeiro. Mas vou insistir em reparos e especulações.

Ao mesmo momento em que os franceses horrorizavam os mares do Brasil, o rei Fernando agonizava em Madrid. O secretário Sebastião e o rei José tinham informações privilegiadas e preocupações agudas com o caso. O receio não era tanto pela saúde do cunhado do monarca português, mas pelos rumos que seu desaparecimento poderia proporcionar. Com a morte do secretário José de Carvajal y Lancáster em 1754, a corte del Prado mandou buscar o secretário Ricardo Wall em Londres. Carvajal y Lancáster era tido como mais "previsível". Tinha negociado e assinado o tratado de limites de 1750. Tinha boas relações com a corte portuguesa. Era inclusive parente longínquo do rei português e da rainha espanhola. ${ }^{18}$ Ricardo Wall era espécie de secretário Sebastião faz-decide-aprova-tudo do rei Fernando. Era um muro. Uma muralha. Justo como seu nome indicava. Homem de convicções e forte caráter. De família irlandesa fugida de guerra religiosa inglesa, Wall nascera em Nantes na França e se mudara para a Espanha para ser militar em Cadiz em 1717. Durante mais de trinta anos de caserna, ganhou confiança na corte e recebeu incumbências diplomáticas em missões de paz. Foi o caso em Londres em fins dos quarentas. Anti-inglês empedernido, acumulou numerosos desafetos em Westminster. De volta à Espanha em lugar de Carvajal y Lancáster, teve atuação discreta até o estouro da guerra de sete anos. Desde então, posicionou a política espanhola claramente contra o arco de alianças inglês. Coincidiu

\footnotetext{
17 Id., 263.

18 José Miguel DELGADO - El proyecto político de Carvajal: pensamiento y reforma en tiempos de Fernando VI. Madrid: CSIC, 2001. D. OZANAM - La diplomacia de Fernando VI. Correspondencia entre Carvajal y Huéscar, 1746-1749. Madrid: Escuela de Historia Moderna, Madrid, 1975.
} 
com o início da guerra o agravamento da saúde do casal real espanhol. Fruto da situação, o poder e a influência do secretário Ricardo Wall foram rápida e decisivamente aumentando. $\mathrm{O}$ secretário Sebastião acompanhava essa movimentação com interesse ativo. Mesmo que a distância. Sabia perfeitamente das posições de seu homólogo. E não era segredo para ninguém a intenção do sr. Ricardo Wall em suprimir todas as atividades em torno do tratado de limites nos moldes em que tinha sido assinado em 1750. Só não o fazia por impedimento do rei e da rainha. ${ }^{19}$ Pelo que informa Maria Fernanda, a intenção-decisão do secretário Sebastião de passar imediatamente o governador Bobadela de Sacramento para o Rio de Janeiro foi materializada em outubro de 1758. Em outubro de 1758, a corte lusa ainda sorvia o luto do desaparecimento da irmã do rei José, dona Maria Bárbara em Madrid, ocorrido no último agosto, sabia da recaída emocional e mental do rei Fernando e da ascensão definitiva do secretário Ricardo Wall sobre administração espanhola. Em adição, Edward Hay, o embaixador inglês que substituíra Abraham Castres em Lisboa desde fins de 1757 e mantinha contato direto com o secretário Sebastião, conhecia mais que ninguém o feitio, a personalidade e os planos do secretário espanhol. Além de terem sido contemporâneos em Londres menos de dez anos antes, o embaixador Hay acompanhava a indisposição insistente do secretário Ricardo Wall com o enviado inglês em Madrid, o lord Bristol, com relação aos domínios coloniais ingleses e portugueses. ${ }^{20}$

Por isso, o secretário Sebastião pode ter antecipado a retirada do governador Bobadela das negociações com os espanhóis no sul também por estar convicto de que a ação estava com dias contados a partir dali. Mesmo que não, obviamente, prevendo, ou querendo, a morte do rei Fernando, a ascensão de dom Carlos e a extinção do tratado, o secretário Sebastião, por certo, tinha calculado que com o avanço da guerra e com o avanço do secretário Ricardo, o fim do tratado, ou ao menos seu bloqueio, era inevitável. Sendo assim, o nobre governador Bobadela estava perdendo tempo e correndo risco no sul.

\footnotetext{
${ }^{19}$ D. TÉLLEZ ALARCIA - La supuesta anglofilia de D. Ricardo Wall. Filias y fobias políticas durante el reinado de Fernando VI. Revista de Historia Moderna. Anales de la Universidad de Alicante, 21, pp. 501-36, 2003. D. TÉLLEZ ALARCIA - Richard Wall: light and shade of an Irish minister in Spain (1694-1777). Irish Studies Review, 11.2, pp. 123-36, aug. 2003.

${ }^{20}$ John LYNCH - El siglo XVIII. Barcelona: Crítica, 1991. María José RUBIO - Reinas de España. Siglos XVIII al XXI. De María Luisa Gabriela de Saboya a Letizia Ortiz. Madrid: Editorial La Esfera de los Libros, 2009. Macarena MARQUEZ - Bárbara de Braganza. Madrid: Eila Editores, 2011. Quadro elementar das relações políticas e diplomáticas de Portugal com diversas potências do mundo desde o princípio da monarquia portuguesa até os nossos dias ordenado e composto pelo visconde de Santarém. Lisboa: Typ. da Academia Real das Sciencias, tomo 8, 1864. pp. 354-5.
} 
Esse floreio não inutiliza a tese de Maria Fernanda. Apenas sugere mais cores. O Rio de Janeiro era importante. O governador Bobadela, como dos mais experientes servidores do império português nas bandas americanas, deveria estar aí ou em outro lugar também, ou ainda mais, importante. Por essa razão, o secretário Sebastião lhe ofereceu o posto da Bahia como vice-rei do Brasil. Aqui, a tensão forte com Maria Fernanda fica inevitável.

Datou de 16 de abril de 1761 a carta régia que impôs ao governador Bobadela ir para a Bahia. Conteúdo justo. Objetivo. Direto. Sem sustância, nem adjetivo. Vos quero vice-rei, vos quero na Bahia. Logo. Vá. Nada mais. O distinto governador não foi e levou quase um ano para se justificar. Suas explicações apareceriam em carta do dia 26 de março de 1762. Localizei e analisei a carta. Em primeira impressão, sucumbi, como Maria Fernanda, ao seu encanto. Na sequência, tudo mudou.

Contrárias às aparências e insinuações, a capital do estado do Brasil era São Salvador da Bahia de Todos os Santos. Era o endereço e a referência de Portugal nas Américas. A morte do conde de Lavradio e o bate-cabeça do governo provisório colocou a corte lusa em apreensão. Os últimos anos vinham sendo difíceis. 1759, muito especialmente. A execução dos Távoras e o assalto inglês aos navios franceses em Lagos amplificaram toda sorte de complicações. A oposição ao secretário Sebastião, dentro e fora de Portugal, aumentou enormemente. Os negociantes ingleses que residiam em Lisboa ou no Porto só faziam pressionar. O novo enviado francês não fazia outra coisa senão apoiar essa pressão. A morte do rei Fernando e a ascensão de dom Carlos ao trono espanhol foi outro ponto de pressão. Complicação. A aproximação entre os tronos de França e de Espanha, desnecessário mencionar que também o foi. Os acontecimentos tinham ganhado velocidade e densidade. A guerra era iminente. Quando o enviado extraordinário inglês, conde Kinnoull, chegou a Lisboa em 1760 para ajudar a resolver problemas, o secretário Sebastião estava perplexo. O movimento do duelo franco-inglês estava para massacrar duas peças fundamentais de seu império. Brasil e Portugal. Os franceses tinham estado em peso no Rio de Janeiro em 1757. Mas não para atacar. Faziam apenas uma parada para rumar para o Índico para acometer ingleses. $^{21}$ Agora, além de flanar suas bandeiras por toda costa brasileira, estavam estacionados em Cayenne aguardando permissão para avançar e dominar o estado do GrãoPará e Maranhão, a Amazônia e avançar até a cidade da Bahia. No outro extremo, os

\footnotetext{
${ }^{21}$ Maria Fernanda BICALHO - As noções de capitalidade no Rio de Janeiro sob a política pombalina, op. cit., p. 261. Para uma visão geral das investidas dos franceses em costas brasileiras, ver Vasco MARIZ - BrasilFrança: Relações históricas no período colonial. Rio de Janeiro: Biblioteca do Exército, 2006.
} 
espanhóis estavam esperando brecha para tomar o Rio Grande de São Pedro, ilha de Santa Catarina e tudo mais que se pudesse. Na Europa, forças franco-espanholas, ainda antes do pacte d'amitié, contavam com em breve despachar em Belém, de preferência na birô do secretário Sebastião. O conde Kinnoull percebeu o clima incerto imediatamente ao chegar e comentou seguidamente ao seu superior em Londres, o chanceler Willian Pitt. Ficou surpreso com a apatia da corte lusa na nomeação de alguém vice-rei para cobrir o defunto Lavradio. A despeito do agito constante no gabinete do secretário Sebastião, sobre esse assunto, observara o inglês, tudo estava "very quiet". Sem vice-rei, imaginava, era que o estado do Brasil estava descabeçado. Mas os British tinham muito mais que fazer que convencer o secretário a se mover. $^{22}$ Ele se moveu concorrendo para a nomeação do governador Bobadela vice-rei. Naquele março-abril-maio de 1761, a ofensiva da guerra tornava totalmente direção Portugal. O trato do Prado que anulou o tratado de limites de 1750 deu o tom. Foi de posse dessa informação que o secretário Sebastião confidenciou estar prevendo o fim de tudo. Segundo sua avaliação, sussurrava em segredo ao embaixador Edward Hay, depois daquilo que se fizera no Prado era só esperar a invasão dos espanhóis. Qualquer resquício de neutralidade que pudesse existir, evaporara. O secretário Sebastião fez marcar, descreveu Hay a Pitt, que seu homólogo espanhol servia de maestro da aliança franco-espanhola contra Portugal. Que era o cabeça da ação. O detalhe marcante da evidência era o esforço que os espanhóis estavam fazendo para enviar crescentes quantidades de prata para Paris. Visto que, por mar, risco grande era certo, estavam mandando por terra e com reforço de proteção das duas coroas. ${ }^{23}$ Francesa e espanhola. O secretário Sebastião via o cerco se fechando. Sabia que tudo ia ficar ainda mais hostil em toda parte. Muito especialmente nos limites com a Espanha. No rio da Prata, por exemplo. De todo modo, queria o nobre Bobadela na Bahia. A Bahia, para o luso secretário Sebastião, era a "síntese" do Brasil. Difícil encontrar outra razão. Como também foi provável que seu cálculo ao promover seu nobre governador vice-rei era precisamente pôr a administração geral do estado em boas mãos para deixar. Ao menos naqueles momentos. Bobadela não foi. Os espanhóis estavam para tomar o sul na América e o norte em Portugal. ${ }^{24}$ Nessas circunstâncias, quase ano depois da ordem real, com todo homem importante de Lisboa consumido pela noite sem fim que a entrada da Espanha na guerra imputou, foi que a resposta do governador Bobadela chegou ao secretário Sebastião. Difícil encontrar argumento

\footnotetext{
${ }^{22}$ Earl of Kinnoull to W. Pitt. Lisboa, 11 de outubro de 1760. The National Archives - Londres, State Paper Foreing - Portugal, 89/53 - folio 105.

${ }^{23}$ E. Hay to W. Pitt. Lisboa, 28 de março de 1761. The National Archives - Londres, State Paper Foreing Portugal, 89/54.

${ }^{24}$ E. Hay to Earl of Egremont. Lisboa, 23 de dezembro de 1761. The National Archives - Londres, State Paper Foreing - Portugal, 89/54.
} 
para justificar esse atraso. Além do atraso, a insubordinação. Olhando de longe e em retrospectiva, o caso pode ser mais um forte exemplo para ratificar o caráter autônomo, coorporativo, autogovernado e negociado das ações nos diversos lugares do império ultramarino português. Conceitos vivos nas abordagens de Maria Fernanda. Mesmo assim, as lacunas sobressalentes continuam a incomodar. Estaria o nobre luso secretário geral malinformado sobre a "reorganização" espacial do Brasil? Não tinha noção da acrescida importância relativa do Rio de Janeiro no controle e no manejo da defesa do "norte" e do "sul"? Subestimava ou era indiferente aos "novos" contornos daquele estado que era o Brasil? Provável, mas não acredito. Seu irmão, o Francisco Xavier Mendonça Furtado, responsável pelo conselho ultramarino, estava permanentemente atento aos movimentos das e nas colônias. Nenhuma das razões que Bobadela utilizara para justificar sua desobediência era novidade. Daí em diante, ao menos duas proposições podem ganhar força. O lugar da Bahia e o que realmente disse Bobadela. Mandar Bobadela para Bahia demonstrava, aqui vou me repetir, que a Bahia deveria continuar a cidade-cabeça-capital. Suas centralidade e "capitalidade" seguiam intactas. Na outra ponta, na essência do discurso de Bobadela não foi mencionado - e tenho para mim que nem insinuado - que a capital deveria mudar para o Rio de Janeiro. ${ }^{25}$ Muito embora a chamada do documento seja

1762, Abril, 12

OFÍCIO do [governador do Rio de Janeiro, Minas Gerais e São Paulo], conde de Bobadela, [Gomes Freire de Andrade], ao [secretário de estado do Reino e Mercês], conde de Oeiras, [Sebastião José de Carvalho e Melo], apresentando os resultados referentes à situação em Buenos Aires e a movimentação de D. Pedro de Cevallos e suas tropas; expondo os motivos que o impedem de recolher-se na Bahia, justificando as razões de se transferir a capital para o Rio de Janeiro, devido a sua boa localização, capacidade de defesa e importância econômica, e devido às notícias recebidas de Pernambuco que indicavam a possibilidade de uma guerra envolvendo Portugal, visto o reino de Castela ter declarado guerra a Inglaterra.

AHU- Rio de janeiro, cx. 70, docs. 28, 29, 40 e 65; Brasil Limites, cx. 2, doc. 125.

Dado ao requinte, ao esmero, o desejo inovador e a, de fato, inovação da argumentação densa e pioneira de Maria Fernanda, o diálogo pode se converter em toada sem

\footnotetext{
${ }^{25}$ AHU - Rio de Janeiro, cx. 70, docs. 28, 29, 40 e 65; Brasil Limites, cx. 2, doc. 125.
} 
fim. Abordarei apenas mais um, dois pontos antes de mudar o rumo. O ponto está no centro de tudo: sua utilização da noção de "capitalidade".

Se bem entendo, no seu entender, a realização da "capitalidade" do Rio de Janeiro ocorreu em 1808, quando a cidade se tornou "corte e capital da monarquia e do império português." Esse coroamento foi a consumação do "papel de articulação e defesa da região meridional da América portuguesa, assim como de centro-ultramarino comercial e financeiro no Atlântico-sul" fortalecido "nos últimos anos daquela centúria". ${ }^{26}$ A obviedade do argumento - tornado óbvio muito graças às explicações de Maria Fernanda - se transformou numa realidade analítica esmagadora. O feito Rio de Janeiro, em menção ao capítulo forte do livro de Catarina Madeira que sustenta Maria Fernanda ${ }^{27}$, foi uma experiência extraordinária. Mas me restam dúvidas sobre a competência dos conceitos na caracterização desse evento no momento justo da transformação do Rio de Janeiro em capital. Dito de modo mais claro: até a morte do providencial governador Bobadela em 1763, a capital na cabeça do secretário Sebastião era a Bahia. Aqui começa outra tensão com Maria Fernanda.

Na apresentação dos conceitos-base do argumento de Maria Fernanda, "capitalidade” e "centralidade" aparecem como sinônimos. Em outros termos, "capital" e "centro", forçados, também viram o mesmo. Difícil conceber que sejam iguais. O termo "capitalidade", se sigo bem, possui uma carga de intencionalidade que inevitavelmente namora o anacronismo. Sugere que determinado lugar tende a ter ou agregar disposição para virar capital. Num plano amplamente abstrato, Milton Santos, em seu incontornável A natureza do espaço, chamou a atenção para a intencionalidade dos lugares. Para tanto, projetou e defendeu a rugosidade dos espaços como uma noção essencial. Em seus termos, rugosidades são heranças físicoterritoriais e heranças socioterritoriais ou sociogeográficas que compõem a base espacial que pode se manifestar em espaço usado e espaço vivido. ${ }^{28}$ Traduzindo livremente o caráter quase críptico da formulação, o fluxo da vida dos e nos espaços pode lhes dar centralidade. Nesse sentido, Maria Fernanda foi providencial ao historicizar as razões que conduziram o Rio de Janeiro a "centro de uma complexa rede de interesses, negócios, políticas que articulavam e conferiam unidade ao Atlântico sul português". ${ }^{29}$ Entretanto, a intencionalidade dos lugares não tem poder de

\footnotetext{
${ }^{26}$ Maria Fernanda BICALHO - As noções de capitalidade no Rio de Janeiro sob a política pombalina, op. cit., p. 266.

${ }^{27}$ Ver $O$ "feito de Goa" (1510-1530) in Catarina Madeira SANTOS - "Goa É a Chave de Toda a Índia". Perfil Político da Capital do Estado da Índia (1505-1570). Lisboa: CNCDP, 1999.

${ }^{28}$ Milton SANTOS - A Natureza do Espaço. Técnica e tempo. Razão e emoção. São Paulo: Edusp, 2006.

${ }^{29}$ Maria Fernanda BICALHO - As noções de capitalidade no Rio de Janeiro sob a política pombalina, op. cit., p. 259.
} 
transformar esse lugar em capital. Dito de modo direto: ser centro não é certeza de ser capital. E mais: a unidade e unicidade do centro sempre foi algo discutível em se falando de mundo colonial e de outros mundos. Depois de Cataluña en la España Moderna, obra maior de Pierre Vilar, não fica nenhuma dúvida da fragilidade da determinação entre centro e capital. ${ }^{30}$ Catalunha e Barcelona foram perdendo a "capitalidade" em momento em que possuíam imensa condição cêntrica. Catalunha e Barcelona foram regiões de grande serventia ao império romano. Barcelona, ninguém mais duvida, fôra um dos portos mais importantes daquele império. Depois sediou a dinastia de Aragó. Isso no medievo. Pelos quatrocentos, a nova dinastia de Castilla se instalou em Valladolid - onde por fim viveu a monstruosidade em engenho e agudeza que foi el ingenioso hidalgo que criou don Quijote de la Mancha. Na sequência, a sede foi para Madrid. Desde o pós-guerra de sucessão, o brasão Bourbon se conserva no mesmo lugar n'el Prado. Catalunha e Barcelona mantiveram sua importância econômica, social, cultural e de articulação durante todo o período. Aliás, no fundo da discussão atual sobre catalanismo e separatismo catalão, esta questão segue fundamentalmente viva. A cidade e a região são materialmente centros, mas não possuem a capital. Embora o arranjo da constituição pós-Franco de 1978 tenha condicionado a Espanha em comunidades autônomas, os dias têm nos mostrado que o conflito continua. O "centro" que tem "capitalidade" segue sedento por reconhecimento. ${ }^{31}$ De volta ao passado e ao ponto com Maria Fernanda, Salvador de Sá de Charles Boxer e mais enfaticamente $O$ trato dos viventes de Luiz Felipe de Alencastro conferem substância ao reconhecimento da centralidade do Rio de Janeiro na articulação daquele mundo ultramarino português. O Rio de Janeiro se transformou em elo essencial do comércio de gente na triangulação Angola-rio da Prata, Luanda-Buenos Aires. ${ }^{32}$ Mas outras partes do Brasil mantinham sua condição de centro e de "capitalidade" intacta e dinâmica. A. J. R. Russel-Wood com seu Centros e periferias e Stuart Schwarz no seu Segredos internos demonstraram de modo irreparável isso que vou dizendo. Contrárias às aparências, e isso representa saber absolutamente sabido, a sede administrativa vai transferida para o Rio de Janeiro no momento de retomada possante da economia baiana e do norte e de declínio relativo importante da quantidade de ouro saída das minas e do porto do

\footnotetext{
${ }^{30}$ Pierre VILAR - Cataluña en la España Moderna. Barcelona: Crítica, 1989. 3vols.

31 Jordi PUJOL - Cataluña-Españha. Madrid: Edición de Ramón Pi, 1996. Ver também CLUB D’OPINIÓ ARNAU DE VILANOVA - Para entendernos - los grandes temas del debate Españha-Cataluña. Barcelona: Ariel, 2001. Josep-Maria TERRICABRAS - Raons $i$ topics: catalanisme i anticatalanisme. Barcelona: La campana, 2001. José Álvarez JUNCO - Mater dolorosa: la idea de España em el siglo XIX. Madrid: Taurus Historia, 2002.

32 Charles Ralph BOXER - Salvador de Sá and the struggle for Brazil and Angola, 1602-1686. London: Greenwood Press, 1975. Luiz Felipe de ALENCASTRO - O trato dos viventes: formação do Brasil no Atlântico Sul. São Paulo: Companhia das Letras, 2000.
} 
Rio de Janeiro. ${ }^{33}$ Em formas breves, centro, capital, centralidade, "capitalidade" são instrumentos de análise extremamente consequentes para a abordagem de nosso problema, mas carregam ambiguidades e inadequações que só pondo história para solucionar. Sem pôr história, fica difícil justificar as razões que levaram a Bahia, cidade-centro e cidade-capital, a perder sua "capitalidade" de uma hora para outra. E, por outro lado, mesmo com tudo que vem sendo dito sobre o Rio de Janeiro, ainda não ficou clarividente como essa cidade-centro com latentes potenciais de capital se tornou capital. O cotidiano em colônia possuía dinâmica própria. Essa afirmação, apresentada dessa forma, chega a ser constrangedora de tão escolar e óbvia. Mas não seria demais realçar que as decisões, querendo ou não querendo certos intérpretes no posteriori e os próprios viventes da hora marcada, vinham do centro que era Portugal e, muito especificamente, do centro-do-centro que era o gabinete do secretário Sebastião. E ainda não foram devidamente explicadas as razões que o levaram a modificar seus planos entre a carta régia de abril de 1761 e o ofício de julho de 1763.

\section{Segredos internos}

No verão europeu de 1987, Kátia Mattoso fez publicar na Histoire, économie et societé a apresentação de seu monumental Au nouveau monde que receberia tradução e edição brasileira anos depois como Bahia, século 19. O cotejo atento das versões evidencia irrisórias modificações. Umas impostas por limites da tradução. Outras por clara mudança de convicção. Foi o caso do conteúdo da nota 36 do original francês que virou texto corrente na versão brasileira. Na famigerada nota 36, Kátia Mattoso afirmara que a transferência da capital da Bahia para o Rio de Janeiro não correspondeu

à une prise de conscience de la 'montée' du sud ou d'une quelque décadence économique du nord-est. Elle fut uniquement imposée par des necessités immediates: il fallait rapprocher le centre de commandement des armées qui se battaient dans le sud contre les espagnols et mieux surveiller le port de Rio où passaient les exportations d'or du Minas, du Mato Grosso et de Goias. ${ }^{34}$

\footnotetext{
33 Stuart SCHWARTZ - Segredos internos, op. cit., cap. 15. A. J. R. RUSSEL-WOOD - Centros e Periferias no Mundo Luso-Brasileiro,1500-1808. Revista Brasileira de História, v. 18, n. 36, 1998. Kenneth MAXWELL A devassa da devassa. A Inconfidência Mineira. Brasil e Portugal (1750-1808). 5. ed. São Paulo: Paz e Terra, 2000.

${ }^{34}$ Kátia MATTOSO - Au nouveau monde: une province d'un nouvel empire: Bahia au XIX siècle. Histoire, économie et societé, 4ème trimestre, pp. 535-69, 1987.
} 
Como texto ou como nota, a afirmação pode ser entendida como o reforço da convicção da centralidade da Bahia ao longo dos setecentos e como a inevitabilidade da transferência imposta pela necessidade do momento. A inexistência d'une prise de conscience de la 'montée' du sud golpeia forte qualquer insinuação de intencionalidade que a cidade do Rio de Janeiro poderia possuir no quesito se transformar capital. Deve de ter causado surpresa imensa em todos os rincões brasileiros a notícia da mudança da capital. Fumo, couros, arroz, algodão e açúcar, produtos tipicamente baianos e do norte, sem mencionar as grandes quantidades de ouro e pedras preciosas extraídas de minas baianas, continuavam sendo os artigos de exportação mais valiosos do comércio exterior brasileiro. A dissuasão da conscience dessa condição material real demorou a se fazer. A Bahia, para retomar os termos de Marly da Motta, continuou sendo. Stuart Schwartz, que junto com Kátia Mattoso representam inquestionavelmente os maiores sabedores do que se passava na Bahia daqueles dias, afirmou em seus Segredos internos que, como não se tinha nada a fazer depois da transferência da capital para o Rio de Janeiro, sobrou aos baianos apenas o ressentimento. ${ }^{35}$ Ou seja, a irresistível "memória da capitalidade". Confesso ter passado grande do tempo lendo, entendendo, escutando e acreditando nisso. Que a mudança da capital foi um duro e rude golpe na gente baiana. Recompondo as ideias e reavaliando as informações, não encontrei nenhuma evidência de que no imediato pós-julho de 1763 o pranto colossal tenha invadido o consciente dos baianos. O mesmo questionamento invertido não tem resposta satisfatória no caso oposto experimentado pela gente do Rio de Janeiro. Então ocorre de retomar questões de princípio abandonadas na formulação da proposição. Quais eram as vantagens objetivas, percebidas e reconhecidas, de uma cidade-capital naquele mundo da colônia? A resposta a essa questão aparentemente primária e banal pode reorientar toda a avaliação sobre o assunto.

Não resta muita dúvida que a rivalidade entre os da Bahia e os do Rio de Janeiro - e entre os de outras localidades do Brasil também - foram ganhando força com a tomada de consciência da condição espacial, colonial depois imperial depois no depois, comum. ${ }^{36}$

\footnotetext{
${ }^{35}$ Stuart SCHWARTZ - Segredos internos, op. cit., p. 340.

${ }^{36}$ Para o caso baiano, ver, dentre outros, Braz do AMARAL - Recordações históricas. Porto: Typ. Econômica, 1921. Braz do AMARAL - Fatos da vida do Brasil. Bahia: Tipografia Naval, 1941. José Álvares AMARAL Resumo Chronologico e noticioso da Província da Bahia desde o seu descobrimento em 1500. Revisto e consideravelmente annotado por J. Teixeira Barros. 2. ed. Bahia: Imprensa Oficial do Estado, 1922. pp. 174-5. Francisco M. de Góes CALMON - Vida econômico-financeira da Bahia - elementos para história de 1808 a 1899. Bahia: Imprensa Oficial do Estado, 1925. pp. 50-1 ss. Francisco BORGES DE BARROS - $\grave{A}$ margem da história baiana. Bahia: Imprensa Oficial do Estado, 1934. Arnold WILDBERGER - Os presidentes da Província da Bahia. Salvador: Typ. Beneditina, 1949. pp. 67-117. Affonso RUY - História política e administrativa da cidade de Salvador. Salvador: Beneditina, 1949. p. 389. Wanderley PINHO - A Bahia,
} 
Quando o paulista, o pernambucano, o bahiense, o fluminense que havia entrado os setecentos reivindicando convictamente a condição de português, entrou e navegou os oitocentos convencendo-se progressivamente a ser brasileiro, tudo mudou. A interiorização da metrópole e o processo de independência colaboraram enormemente para essa mudança de percepção. A responsabilidade do Rio de Janeiro como cidade-capital, como centro e como pretensa síntese do país virou necessidade e obsessão. Não foi outro o contraponto senão a negação permanente dessa condição na manifestação de revoltas permanentes contra a autoridade do Rio de Janeiro. O movimento separatista baiano liderado pelo Francisco Sabino em 1837-8, para ficar apenas num exemplo, foi mostra efetiva disso. ${ }^{37}$ Desnecessário avançar mais para

1808-1856. In.: Sérgio Buarque de HOLANDA (Dir.) - História Geral da Civilização Brasileira. O Brasil monárquico: dispersão e unidade. Regência. Rio de Janeiro: Bertrand Brasil, 2002. F. W. O. MORTON - The Conservative Revolution of Independence: economy, society and politics in Bahia, 1790-1840. Oxford, 1974. (Tese apresentada à Oxford University). João José REIS - A elite baiana face aos movimentos sociais, Bahia: 1824-1840. Revista de História, São Paulo, vol. LIV, pp. 341-84, 1976. Luís Henrique Dias TAVARES - A Independência do Brasil na Bahia. Rio de Janeiro: Civilização Brasileira, 1977. João José REIS - O levante dos malês na Bahia: uma interpretação política. Estudos Econômicos, v. 17, n. Especial, pp. 131-49, 1987. João José REIS - Um balanço dos estudos sobre as revoltas escravas da Bahia. In.: João José REIS - Escravidão e invenção da liberdade: estudos sobre o negro no Brasil. São Paulo: Brasiliense, 1988. João José REIS \& Eduardo SILVA - Negociação e conflito: a resistência negra no Brasil escravista. São Paulo: Companhia das Letras, 1989. João José REIS - A morte é uma festa: ritos fúnebres e revolta popular no Brasil do século XIX. São Paulo: Companhia das Letras, 1991. Kátia MATTOSO - Bahia, século XIX: uma província no Império. Rio de Janeiro: Nova Fronteira, 1992. Lina Maria Brandão de ARAS - A Santa Federação Imperial: Bahia, 1831-1833. São Paulo, 1995. (Tese apresentada ao programa de pós-graduação do departamento de História da FFLCH-USP). João José REIS - Identidade e diversidade étnicas nas irmandades negras no tempo da escravidão. Tempo, Rio de Janeiro, v. 2, n. 3, pp. 7-33, 1997. Bert BARICKMAN - A Bahian Counterpoint: sugar, tabacco, cassava, and slavery in the Recôncavo, 1780-1860. Stanford: Stanford University Press, 1998. Cândido da COSTA E SILVA - Os Segadores e a Messe: o clero oitocentista na Bahia. Salvador: Edufba, 2000. Hendrik KRAAY - Race, state and armed forces in independence-Era Brazil. Bahia, 1790s-1840s. California: Stanford University Press, 2001. Hendrik KRAAY - "Em outra coisa não falavam os pardos, cabras, e crioulos": o "recrutamento" de escravos na guerra de Independência na Bahia. Revista Brasileira de História, São Paulo, v. 22, n. 43, pp. 109-26, 2002. João José REIS - Rebelião escrava no Brasil: a história do levante dos malês em 1835. Edição revista e ampliada. São Paulo: Companhia das Letras, 2003. Hendrik KRAAY - Identidade racial na política, Bahia, 1790-1840: o caso dos Henriques. In.: István JANCSÓ (Org.) - Brasil: formação do Estado e da Nação. São Paulo: Hucitec, 2003. Kátia MATTOSO - Da revolução dos alfaiates à riqueza dos baianos no século XIX: itinerário de uma historiadora. Salvador: Corrupio, 2004. Lucas de Faria JUNQUEIRA - A Bahia e o Prata no Primeiro Reinado: comércio, recrutamento e guerra cisplatina (1822-1831). Salvador, 2005. (Dissertação apresentada ao programa de pós-graduação do departamento de História da FFCH-UFBa).

37 O conjunto dessas proposições envolve discussões e debates historiográficos tensos e não consensuais que podem ser encontrados especialmente em Caio PRADO JR. - Formação do Brasil Contemporâneo. Colônia. São Paulo: Publifolha, 2000. Maria Silvia de Carvalho FRANCO - Homens livres na ordem escravocrata. São Paulo: Unesp, 1997. Carlos Guilherme MOTA - A idéia de revolução no Brasil (1789-1801): estudo das formas de pensamento. Petrópolis: Vozes, 1979. Ilmar Rolhoff MATTOS - O Tempo Saquarema. São Paulo: Hucitec, 1987. Richard MORSE - O espelho de Próspero: cultura e idéias nas Américas. Trad. Paulo Neves. São Paulo: Companhia das Letras, 1988. Wanderley PINHO - A Bahia, 1808-1856. In.: Sérgio Buarque de HOLANDA - História Geral da Civilização Brasileira. O Brasil monárquico: dispersão e unidade. Regência. Rio de Janeiro: Bertrand Brasil, 2002. Fernando A. NOVAIS - Portugal e Brasil na Crise do Antigo Sistema Colonial. 8. ed. São Paulo: Hucitec, 2005. Luiz Felipe de ALENCASTRO - O trato dos viventes, op. cit. João FRAGOSO \& Manolo FLORENTINO - O arcaísmo como projeto: mercado atlântico, sociedade agrária e elite mercantil no Rio de Janeiro, 1780-1840. Rio de Janeiro: Diadorin, 1993. João FRAGOSO; Maria Fernanda BICALHO; Maria de Fátima GOUVEIA (Orgs.) - O Antigo Regime nos trópicos: a dinâmica imperial portuguesa (séc. XVI-XVIII). Rio de Janeiro: Civilização Brasileira, 2001. István JANCSÓ - Na Bahia, contra 
exemplificar que a crescente identificação das pessoas com o lugar-região reconhecido como circunscrito a um território único e comum promoveu o aprofundamento do localismo. $\mathrm{O}$ mesmo localismo que dificultou a unificação nacional ao longo dos oitocentos e novecentos construiu, nos casos baiano e carioca, rixas insolúveis cujos instrumentos de guerra mais convincentes acabam sendo a disputa do passado. Daí o convencimento de que a cidade-Rio de Janeiro-capital sempre foi destino manifesto e, do contrário, perder a capital foi um golpe nos baianos.

\section{A natureza da capital}

Cidade-capital é uma prática recente. Moderna. Demanda da necessidade de centralização da autoridade. Até os inícios dos quinhentos, poder real e poder municipal eram as medidas do mundo. O primeiro estado moderno a alterar essa divisão foi o inglês. Foi com Henry II que a cidade-centro passou a cidade-capital. Essa opção foi em resposta ao aumento da burocracia e da necessidade dela. O aparato de administração financeira foi o pioneiro em centralidade. Em seguida, praticamente todos os outros offices of states. Cortes de justiça, arquivos, centros de negócios oficiais. Isso atualizou a utilização do espaço. Novas formas arquitetônicas foram pensadas e executadas. Prédios foram construídos. Sempre seguindo decoro e hierarquia. Avenidas foram abertas. Sempre inspirada em imensa sofisticação. Sistemas de proteção também. Sempre focados em certa geometria imaginária de poderes. Depois do século XVI, esse modelo era praticamente absoluto em todo o Ocidente. Não que isso tenha desmantelado os agrarian empires. Do contrário. Eles foram reforçados. Teriam ainda vida longa. Mas a cidade-capital e as cidades de modo geral passaram a monopolizar a população. Em algum momento da passagem dos quinhentos aos seiscentos, as cidades e as

o Império. História do ensaio de sedição de 1798. São Paulo: Hucitec, 1996. István JANCSÓ \& João Paulo G. PIMENTA - Peças de um mosaico (ou apontamentos para o estudo da emergência da identidade nacional brasileira). In.: Carlos Guilherme MOTA - A viagem incompleta. A experiência brasileira (1500-2000). Formação: Histórias. São Paulo: Senac, 2000. István JANCSÓ (Org.) - Brasil: formação do Estado e da Nação. São Paulo: Hucitec, 2003. István JANCSÓ - Independência no Brasil: história e historiografia. São Paulo: Hucitec, 2005. Paulo César SOUZA - A Sabinada: a revolta separatista da Bahia. São Paulo: Círculo do Livro, 1987. Daniel Afonso da SILVA - Histórias de Bahia, Histórias de Brasil: cinco estudos sobre a crise do primeiro reinado na Bahia (1828-1831). São Paulo, 2007. (Dissertação apresentada ao programa de pósgraduação do departamento de História da FFLCH-USP). Gladys Sabina RIBEIRO - A liberdade em construção. Identidade nacional e conflitos antilusos no Primeiro Reinado. Rio de Janeiro: Relume-Dumará, 2002. Marco MOREL - As transformações dos espaços públicos: imprensa, atores políticos e sociabilidades na cidade imperial (1820-1840). São Paulo: Hucitec, 2005. João José REIS - Rebelião escrava no Brasil: a história do levante dos malês em 1835. Edição revista e ampliada. São Paulo: Companhia das Letras, 2003. Hendrik KRAAY - Race, state and armed forces in independence-Era Brazil. Bahia, 1790s-1840s. California: Stanford University Press, 2001. 
redes urbanas deram de crescer muito rapidamente. Londres passou a possuir 250 mil habitantes. Nápoles, 240. Milão, 200. Paris, 180. Palermo e Roma, pouco mais que 100. Lisboa, Sevilha, Antuérpia e Amsterdam, quase 100. O reenquadramento financeiro ao longo dos seiscentos fez Moscow e São Petersburg saltaram para mais de 200 mil almas e Berlim e Copenhagem, para mais de $100 .^{38} \mathrm{O}$ efeito cidade e cidade-capital sobre as pessoas foi arrasador. Cidade supunha civilização. Civilização era, antes de tudo, coerção. Coerção em sentido de polir, policiar. Colocar diferentes em pé de igualdade. Abrandando seus costumes e educando seus espíritos. Possibilitando o desenvolvimento de sua polidez. Expondo-lhes a cultura das artes e da ciência. Possibilitando-lhes, a partir do crescimento do comércio e da indústria, a aquisição de comodidades materiais e de luxo. O polir e o policiar eram a esperança para bárbaros, selvagens, camponeses, crianças. ${ }^{39}$ Por esse momento e por essas características, campo e cidade passaram a dormir separados e terem sonhos diferentes. $\mathrm{O}$ mundo rural passou a ser entendido como o refúgio da inocência. $\mathrm{O}$ da cidade, o império da mentira. ${ }^{40}$ Não tardou o desmascaramento do efeito civilidade. Foi de pronto a afirmação da convicção de que a civilização, por si e para si, reitera, em essência, a brutalidade primitiva e o que há de pior nos homens sob aparências enganadoras e dissimuladas. ${ }^{41}$ Mas a partir daí, não tinha mais volta. A cidade e a cidade-capital passaram a ditar o destin du monde. Sua posição passou a ser privilégio. Esse privilégio, caminho de prosperidade. ${ }^{42}$

Os chineses foram dos primeiros a perceber essa força. Em 1421, o império Ming fez mudar a capital de Nanquim para Pequim. O ponto simples. Questão de estratégia. Percepção de futuro. Plano prospectivo. Pequim estava mais bem posicionada para a exploração de novas rotas de navegação. $\mathrm{O}$ exemplo invertido veio com os ibéricos. Depois do desaparecimento do rei Sebastião e da união dos reinos, Felipe II, por 1582, mandou concentrar a administração dos dois mundos, agora um, em Madrid. "Quelle erreur!", conjeturou Fernand Braudel. Deixando Lisboa se estava deixando o coração do império. Sem justificativa. Sem explicação. Foi, sim, imenso erro. Com, sim, consequências. Sem perdão. ${ }^{43}$

\footnotetext{
${ }^{38}$ Lewis MUMDORF - The culture of cities. Londres: Secker \& Warburg, 1940. pp. 78-98.

39 Jean STAROBINSKI - As máscaras da civilização. Trad. Maria Lúcia Machado. São Paulo: Companhia das Letras, 2001. pp. 14-5, 28.

${ }^{40}$ Raymond WILLIAMS - O campo e a cidade na história e na literatura. Trad. Paulo Henrique Britto. São Paulo: Companhia das Letras, 1990. pp. 69-70.

${ }^{41}$ Jean STAROBINSKI - As máscaras da civilização, op. cit., p. 19.

${ }^{42}$ Fernand BRAUDEL - Civilisation materiélle, économie et capitalisme - XVe-XVIIIe siècle. 1. Les structures du quotidien. Paris: Armand Colin, 1993. pp. 547, 571.

${ }^{43}$ Fernand BRAUDEL - Civilisation materiélle, économie et capitalisme - XVe-XVIIIe siècle. 3. Le temps du monde. Paris: Armand Colin, 1993. p. 27.
} 
O sentido da capital (1)

A intuição de Caio Prado Jr. insinuou o que muita pesquisa documental iria - e, certamente, irá - comprovar. Numa passagem discreta de seu Formação do Brasil Contemporâneo, afirmou que "O Brasil não constitui para os efeitos de administração metropolitana, uma unidade", a não ser na geografia e no "consenso de todos". ${ }^{4}$ Essa ausência de unidade real cunhava a diferença fundamental entre cidade e cidade-capital no centro, os reinos, e nas periferias dos centros, os domínios. Fora do centro, a cidade e a cidade-capital eram apenas, como bonitamente expressou Milton Santos, "a encarnação do poder longínquo, uma vontade de marcar presença num mundo distante". ${ }^{45}$ Pelo século XVI, os portugueses fundaram não mais que três cidades nas Américas. São Salvador da Bahia de Todos os Santos (1549), São Sebastião do Rio de Janeiro (1565) e Filipéia de Nossa Senhora das Neves (1585). No século XVII, umas sete. Sendo São Luís do Maranhão (1612), Nossa Senhora de Belém (1616), Olinda (1676) e Nossa Senhora da Luz dos Pinhais de Curitiba (1693) as principais. No século XVIII, em torno de dez. Sendo São Paulo (1711) a que merece menção. Em grosso, trezentos anos, vinte cidades. O que mais se viu e se fez foram vilas. 14 no século XVI; 51, no XVII; 60, no XVIII. ${ }^{46}$ Essas cidades e a capital nasceram modernas. Seguiam a matriz da centralização da autoridade. A diferença sensível estava na função. Cidade e capital, nesse mundo colonial, tinham a mesma função. O mesmo sentido. Quase a mesma utilidade. Serviam de "metrópole regional". ${ }^{47}$ Diferente da cidade, a capital dava abrigo ao vice-rei. Nada mais. Ou melhor, algo mais. Não muito. No primeiro momento, o corpo de altos funcionários portugueses foi instalado na cidade da Bahia. A administração, o expediente militar e a burocracia das finanças passavam por aí. A governação geral de geral só tinha o nome. A distância e o vazio eram reais. Sem caminhos, ficava mais operacional Lisboa falar direto com São Luís ou Curitiba que pedir intermediação de alguém em São Salvador. A autonomia das cidades frente à capital era uma realidade diante da ausência de unidade. ${ }^{48}$ A maior parte das pessoas, vivendo suas vidas, nem sabiam que existia cidade da cidade-Bahia-capital. O núcleo de peregrinação geral e quase absoluto era Portugal. Cujo Lisboa-Belém, e depois o gabinete do secretário Sebastião, era a capital.

\footnotetext{
${ }^{44}$ Caio PRADO JR. - Formação do Brasil Contemporâneo, op. cit., p. 313.

${ }^{45}$ Milton SANTOS - A urbanização brasileira. São Paulo: Edusp, 2008. p. 19.

${ }^{46}$ Nestor GOULART REIS FILHO - Contribuição ao estudo da evolução urbana do Brasil (1500-1720). São Paulo: Pioneira, 1968. Darcy RIBEIRO - O povo brasileiro. A formação e o sentido do Brasil. São Paulo: Companhia das Letras, 1995. p. 194.

${ }^{47}$ Milton SANTOS - O centro da cidade de Salvador. São Paulo: Edusp, 2008. p. 41.

${ }^{48}$ Caio PRADO JR. - Formação do Brasil Contemporâneo, op. cit., pp. 307 ss.
} 


\section{O sentido da capital (2)}

Mesmo sem o mesmo sentido e a mesma importância duma capital d'além-mar, a cidade da Bahia-capital, pelo seu caráter pioneiro, foi primaz. Nos tempos de sua fundação, a cidade-capital acumulava 8 mil almas. ${ }^{49}$ Em cinquenta anos, nos fins do século XVI, tinha mais que dobrado em população. Passou a ter mais ou menos 15 mil pessoas. Sua concorrente regional direta, Olinda-Recife, 5 mil. São Paulo, 1.500. Rio de Janeiro, não mais que mil. Cem anos depois, a população da São Salvador dobrou de novo. Agora contava mais de 30 mil. Ao passo que Recife ia com 20 mil. O Rio de Janeiro, 4 mil. E São Paulo, menos que 3 mil. Na entrada do século XIX, São Salvador não mais capital tinha 40 mil. Rio de Janeirocapital, 43 mil. Recife, 25 mil. Ouro Preto, 30 mil. São Luís, 20 mil. São Paulo, 15 mil. O impacto do século XVIII sobre a demografia da colônia foi espetacular. Quando São Salvador contava com 15 mil almas por volta de 1600, o todo colonial era de 60 mil. Em 1700, a proporção era menos vantajosa. A colônia tinha 300 mil pessoas e a capital, 30 mil. 10\%. Ao longo do século XVIII, a população geral aumentou dez vezes. Passou a 3 milhões. E foi melhor distribuída e acomodada no espaço. A miragem do ouro colaborou decisivamente. Milhões de pessoas ou atravessaram o Atlântico ou trilharam campos e serras para chegar às minas. Ao que concerniu a cidade da Bahia-capital, a perda de gente não foi tão grande. A tendência de crescimento demográfico foi claramente subvertida. Em Recife-Olinda também. E ocorreu o inverso nas capitanias do sul. O Rio de Janeiro, em cem anos, ganhou dez vezes em população. Passou de 4 mil para 43 mil. ${ }^{50}$ Mas o ouro não explica tudo.

O século XVIII presenciou o crescimento global da população mundial. A população da Europa e dos domínios europeus, em média, mais que dobrou. O relance da economia foi fator importante. A flutuação de preços deu lugar a certa estabilidade. O crescimento econômico permitiu muitos outros avanços. Especialmente científicos e políticos. Diminuição da fome. Baixa considerável da mortalidade urbana. Tudo muito em função de progressos em higiene e na medicina. Pela medicina se fez também recuar os casos de varíola e de mortalidade infantil. $\mathrm{O}$ aumento médio da idade média de casamento e procriação também concorreu decisivamente. ${ }^{51}$ Por volta de 1750 , a população mundial era de 800 milhões. Sendo apenas 12 milhões no novo mundo. Londres contava 750 mil. Paris, 500. Portugal

\footnotetext{
${ }^{49}$ Milton SANTOS - O centro da cidade de Salvador, op. cit., p. 39.

${ }^{50}$ Darcy RIBEIRO - O povo brasileiro, op. cit., p. 194.

${ }^{51}$ Fernand BRAUDEL - Civilisation materiélle, économie et capitalisme - XVe-XVIIIe siècle. 1. Les structures du quotidian, op. cit., pp. 40 ss. Richard SENNETT - Carne e pedra: o corpo e a cidade na civilização ocidental. Rio de Janeiro: Record, 2001. pp. 218 ss.
} 
europeu inteiro tinha para lá de 2 milhões e meio. No caso de Paris e Londres o incremento se deu a custa de imigração. Dum momento para outro, uma multidão de desconhecidos passou a viver e falar nos quatro cantos do Reino Unido e da França. ${ }^{52}$ No caso de Portugal, o inverso. A emigração. Emigração para o Brasil. Um cálculo oficial de 1742 estimou que entre 1.500 e 1.600 pessoas deixaram Portugal rumo Pernambuco, Bahia, São Luís do Maranhão, Rio de Janeiro e todas as regiões de minas. O que volteava esses números eram números muito superiores. Só na Bahia, em 1733, três navios de bandeira lusa foram interceptados trazendo mais de 700 passageiros sem autorização para sair de Portugal e sem autorização para entrar no Brasil. ${ }^{53}$ Somados os pés de África e os pés de outras procedências a explicação fica mais completa.

\section{O sentido da capital (3)}

Mesmo com mais gente, a colônia seguiu desunida. Sem união e sem unidade. O vicerei era enviado do rei, mas tinha pouca ou nenhuma similitude com o próprio. O brio e o brilho de sua majestade ofuscavam todo e quaisquer outros brio e brilho. Quando o vicereinado foi transferido ao Rio de Janeiro, ninguém no reino ou nos domínios imaginava outro centro e outra capital que não Portugal, que não Lisboa. Desde Lisboa e desde Londres, nada convergia para a necessidade de mudança de capital nos domínios. O ganho de importância do Rio de Janeiro e de sua área de influência era acompanhado com alguma desconfiança. Os impactos, notadamente o demográfico e o urbanístico, não tinham volta. Em meio século de ouro, muito mudou. Apenas o plano estratégico Lisboa-Londres-Lisboa que não. O ouro era componente da economia. Seu achamento, mesmo que tardio, foi motivo de alegria. Realização. Mas também de hesitação. Açúcar, fumo e negro eram o fundamento econômico da economia metropolitano-colonial(is). Mesmo assim, milhares de pessoas saíram das cidades do norte e foram para o interior. Para o sertão. Para o nada das minas. Ao centro e ao sul. Isso alterou em quase nada o quotidiano da capital. Do contrário, acrescentou trabalho. Muito do ouro encontrado em Rio de Contas, Caetité, Jacobina foi escoado pelo porto da capital da Bahia. E foi esse mesmo porto que viu aumentar consideravelmente as remessas de

\footnotetext{
${ }^{52}$ Richard SENNETT - O declínio do homem público: as tiranias da intimidade. Trad. Lygia Araujo Watanabe. São Paulo: Companhia das Letras, 1988. pp. 70-2. René RÉMOND - El antiguo regimen y la revolución 1750-1815. Trad. Marco Aurelio Galmarini. Barcelona: Vicens-vives, 1980. pp. 30-1. A. J. R. RUSSELLWOOD - Um mundo em movimento. Os portugueses na África, Ásia e América (1492-1808). Trad. Vanda Anastácio. Miraflores: Difel, 2000. pp. 95 ss.

${ }^{53}$ A. J. R. RUSSELL-WOOD - Um mundo em movimento, op. cit., p. 93-4.
} 
negros chegando e fumo saindo. Sem contar o açúcar que ganhou impulso no segundo quartel do século XVIII. O lucro médio do açúcar era mais constante. E após certo desaquecimento decorrente dos efeitos Antilhas e ouro, a produção voltou a patamares importantes. E essa retomada se deu justamente no momento em que o açúcar se afirmou como a primeira mercadoria sobre a base de valor das transações de comércio internacional. Retomar o açúcar era reforçar o negócio do negro. O negócio negro do imundo comércio fazia girar a máquina de maneira estrutural. No espaço Brasil, a produção do açúcar continuava na região de influência da capital. Essa região que dava o mais seguro e essencial ao sustento do reino. Lisboa sabia disso. Londres, pouco se interessava. Seu negócio era outro. Enquanto os reinos hegemônicos, Inglaterra e França, e periféricos, Portugal e Espanha, se engalfinhavam na guerra dos sete anos, o Brasil era o segundo produtor e vendedor de açúcar no mundo. Perdia apenas para o Haiti. Em 1760, conseguiu exportar 34 mil toneladas. 16\% do comércio absoluto. Com retorno absoluto. Ao passo que muito do que saía de Jamaica e Barbados, do Haiti e da Martinica, e mesmo de Cuba ia suprir consumo interno. ${ }^{54}$ Ainda entre 1759 e 1760 , o enviado inglês em Lisboa notou que fazia meses que não via navio chegando com ouro ou diamantes.

Mesmo assim, em 1763 o rei José e o secretário Sebastião mandaram um vice-rei para o Rio de Janeiro. O efeito não fôra positivo nem negativo. A cidade da Bahia não era a Lisboa e o Rio de Janeiro não era a Madrid dos tempos de união ibérica. Talvez tenha sido justamente e somente por isso que se mudou. Mudou o estatuto. Mas a memória de cidadeBahia-capital demoraria ainda muito para se perder. Ou jamais se perderia.

\footnotetext{
${ }^{54}$ Manuel Moreno FRAGINALS - El ingenio. Complejo económico social cubano del azúcar. Barcelona: Crítica, 2001. p. 11-30.
} 


\section{Fatos diversos}

Não escreveremos sucesso que não seja feliz.

Governadores do Brasil, 1762.

A lealdade dos pernambucanos não estima outrossim senão o que oxalá o fogo do amor que professa ao seu soberano.

Luís José Corrêa de Sá

Pernambuco, 1756.

[é] da obrigação do seu ofício administrar justiça dos vassalos de Vossa Majestade que vivem de minerar pelos vastos sertões e povoados daquelas minas.

Pedro Dias Paes Leme Ouro Preto, 1750.

A visita do conde d'Arché ao Rio de Janeiro naqueles dias de julho de 1757 teve repercussão imensa. Escancarou a sabida fragilidade do sistema de defesa da colônia. Mostrou que terra e mar, mais que nunca, estavam desprotegidos. Que as carências navais e militares eram gigantescas. Que o "empório" do comércio brasileiro estava desamparado. Que os "preciosíssimos tesouros de cujos depósitos ou Minas [era] a chave o Rio de Janeiro" estavam susceptíveis à "ardentíssima e pungentíssima inveja" francesa. ${ }^{1}$ Mas muito mais que isso, colocou o Brasil na guerra das potências europeias. Ao menos em sensação e percepção. O "horror" e o "pânico" que invadiram as ruas do Rio de Janeiro não demoraram a se espalhar por toda parte. Toda cidade portuária foi posta em sobreaviso. Notadamente a cidade da Bahia, então capital do Brasil. Depois que a Espanha aderiu ao pacto com a França e abriu

\footnotetext{
${ }^{1}$ Memória de Carvalho de Melo sobre a expedição do conde de Arché apud Maria Fernanda BICALHO - As noções de capitalidade no Rio de Janeiro sob a política pombalina. In.: Ana Cristina ARAÚJO; José Luis CARDOSO; Nuno Gonçalves MONTEIRO et all. (Org.). O terremoto de 1755: impactos históricos. Lisboa: Livros Horizonte, 2007. p. 261.
} 
guerra contra a Inglaterra, a percepção ganhou nuanças de certeza. De Lisboa até seus domínios.

Em meio a toda conversação e estresse que acometia a corte lusa desde os fins de dezembro de 1761, o secretário Sebastião escreveu longa carta ao governo interino na Bahia. Toda tensão das negociações vinha descrita na missiva. A fúria dos espanhóis. As maquinações dos franceses. A incerteza com relação ao apoio dos ingleses. O fim da neutralidade portuguesa diante da possibilidade de agressão franco-espanhola a qualquer instante. Os dias de guerra que estavam vivendo e vivenciando. Todos os domínios do reino deveriam se pôr preparados para coagir o avanço inimigo. No caso do Brasil, reforçar a defesa das fortalezas e das costas marítimas era imprescindível. Embora tudo fosse evidente, o secretário Sebastião fez questão de reavisar. ${ }^{2} \mathrm{O}$ reaviso veio em momento excepcional e por razão excepcional. Ambos, momento e razão, óbvios. Mas quando chegou à Bahia, no dia 12 de fevereiro de 1762, aparecia quase um ano depois de duas cartas régias de 19 de abril de 1761 que serviram de resposta, claramente em atraso, ao incidente de julho de 1757 e de 1759. Em 22 de julho de 1759, esquadra francesa havia adentrado o porto da Bahia e causado péssima impressão aos baianos. De todo modo, as cartas régias de 1761 conferiam aos "governadores do Estado do Brasil" instrumentos legais para se precaver de interesses estrangeiros difusos. Em tempo de guerra iminente como aquele, todos os meios de "prudência" eram essenciais. Nesse sentido, as cartas determinavam que toda embarcação, fosse mercante ou de guerra, seria bloqueada e inspecionada antes de atracar. Mesmo as de bandeira amiga. Mesmo as dos próprios vassalos. O artifício impeditivo, antes das cartas régias, constava da lei de 28 de setembro de 1703 que restringia a inspeção a naus mercantes. ${ }^{3}$ O agravante dessa determinação real não era outro senão a dificuldade de aplicação. Pouca gente e pouca gente competente para fazê-lo. O reaviso do secretário Sebastião, meses depois vinha convencido dessa fragilidade material. Mas insistia na necessidade. A primeira resposta apareceu no dia 4 de abril de 1762 com a assinatura do chanceler-governador interino da Bahia, José Carvalho de Andrade. Manifestação rápida e protocolar. ${ }^{4}$ Seis dias depois, no 10 de abril, junto com seu colega de administração, o frade Antonio de Santa Ignês, o chancelergovernador, enfim, respondeu mais ampla e adequadamente. Fôra dos relatos mais completos que o secretário Sebastião recebera da situação do lado de americano.

\footnotetext{
${ }^{2}$ BNRJ - AMU - Bahia, 5827.

${ }^{3}$ Cartas de 19 de abril de 1761. In.: Marcos Carneiro MENDONÇA - O Marquês de Pombal e o Brasil. São Paulo: Companhia Editora Nacional, 1960. pp. 114-6.

${ }^{4}$ BNRJ - AMU - Bahia, 5827.
} 
"Estamos animados e determinados a uma vigorosa resistência até a última gota de sangue”. Era a convicção dos governadores que acrescentaram que não escreveriam, dali em diante, "sucesso que não fosse feliz". Pura e simplesmente porque, caso ocorresse sucesso que feliz não fosse, estavam dispostos a perder suas vidas "em defesa do rei e da pátria". 5 Longe de qualquer aparência de dissimulação, artifício retórico ou mesmo adulação, os governadores sabiam perfeitamente da gravidade da crise europeia, do esforço da corte lusa para se proteger e dos desafios do Brasil para não trocar de mãos.

A "gente do povo", ciente da guerra, vinha, desde muito, deixando a cidade. Em Recife e no Rio de Janeiro ocorria o mesmo. No temor de perder suas economias, suas mulheres, seus filhos e filhas ou sua própria vida, muita gente fugia para vilas e distritos distantes. Muita vez, ia mata adentro. Esse êxodo da capital era grande empecilho. Era difícil encontrar "homens brancos" para ampliar as forças do exército. Mesmo para os serviços cotidianos, o contingente estava rareado. Exceto um e outro mestre e oficial de ourives, um e outro carpinteiro e pedreiro, a massa da gente do comércio e das tendas, dos lavradores e dos oficiais de trabalhos mecânicos eram todos "pretos". 6 Isso era gerador de desconforto e sensação de abandono. A "nobreza" na cidade estava se sentindo duplamente intimidada. Mesmo que empenhada a lutar até a morte "pelo reino", esses nobres da terra clamavam por segurança. "Soldados pagos de baixo nascimento" tinham sido contratados. Mas era insuficiente. Os capitães-mores das vilas e distritos tinham ordem para fiscalizar o passaporte de toda "gente livre" estranha ao local e fazê-la sair se fosse o caso. Não estava resolvendo. Seria, antes de tudo, fundamental, confidenciavam os governadores, extrair do imaginário dos "bons da terra" o medo da guerra. Mesmo que a guerra fosse um fato difícil de acobertar. ${ }^{7}$

Imediatamente depois de receber o aviso do secretário Sebastião, mandaram reforçar em pólvora os fortes, redutos e fortalezas mais importantes da costa. No dia 5 de abril, transmitiram a ordem ao governador do Rio de Janeiro no primeiro navio que partiu. A Bahia possuía uns quatrocentos barris que foram acrescidos de mais cem chegados de Portugal. Cada barril tinha umas duas arrobas. Por serem "pequenos", poderiam ser transportados em sigilo. Na mesma sequência e com grande discrição, mandaram ordens para os oficiais maiores para alistarem gente para o exército. Comunicaram os "pretos livres" do batalhão de Henrique Dias. Despacharam avisos para todas as câmaras ordenarem aos senhores armarem,

\footnotetext{
${ }^{5}$ BNRJ - AMU - Bahia, 5828.

${ }^{6}$ Id., ibid.

${ }^{7}$ Id., ibid.
} 
“o melhor que pudessem", seus escravos e os mandassem para a capital. Essa gente seria necessária, sobretudo, para o reforço dos contingentes em todas as "peças das fortalezas, cortinas, fortes e marinha". A função essencial, para ficar na discrição, era pôr em execução as cartas régias de 1761. Precisavam de gente para neutralizar os navios em passagem e, mesmo sendo "português", "reconhecer a equipagem" e "a gente que trazia". Em caso de dúvida, mandar alguém rapidamente à terra consultar um superior. Em caso de intransigência, meter o navio "a pique". 8

Muita gente esteve implicada nessa operação. O provedor da fazenda. O fidalgo da casa real. O provedor-mor da fazenda real. Enfim, gente que não necessariamente era amiga. Não necessariamente se gostava. Mas, como informavam os governadores, trabalhavam "alegre e gostosamente de dia e de noite sem descanso" pela convicção de estarem atuando "fidelissimamente" em "serviço de Deus, do rei, do reino e dos seus domínios.",

O núcleo da estratégia geral de vigilância e "defesa vigorosa" dos portos e da costa marítima, preparação de militares e melhoramento das fortificações foi estabelecido na Bahia e pelos governadores interinos, na ausência de vice-rei. O secretário Sebastião confiou a tarefa aos ditos governadores. Uma vez que o governador Bobadela, mesmo no Rio de Janeiro, tinha as preocupações voltadas massivamente para Sacramento.

\section{Donativos}

Após vinte e quatro anos arrecadando e enviando donativos para a reconstrução de Lisboa, num montante próximo de 120 mil cruzados por ano, a gente do Rio de Janeiro decidiu, em reunião sediada em sua câmara, que deveria suspender a ação. ${ }^{10}$ Os fiadores do esforço de arrecadação, o secretário Sebastião e o rei José, não mais governavam Portugal. Muita água movera os moinhos da corte e da colônia.

A matriz da representação endereçada à rainha Maria I alude a um dos eventos mais importantes daqueles 1750s que foi o terremoto de 1755 e sua repercussão. Não apenas em Lisboa. Nas Américas. No Brasil. As "horrorosas e lastimáveis notícias do terremoto" chegaram, em versão oficial, no início de 1756. Somente mês e meio depois do desastre,

\footnotetext{
${ }^{8} I d$., ibid.

${ }^{9}$ Id., ibid.

${ }^{10}$ AHU - Rio de Janeiro, documentos avulsos, cx. 125, doc. 22.
} 
Diogo de Mendonça Corte Real, então secretário do conselho ultramarino, escreveu e remeteu o comunicado aos vassalos do rei José pelos domínios. No caso do Brasil, o destinatário exclusivo foi o conde dos Arcos, vice-rei do Brasil, domiciliado a menos de mês na cidade da Bahia. Após receber a descrição da tragédia, foi o conde dos Arcos quem retransmitiu a notícia aos demais governadores e administradores espalhados por todo o território. Mandou fazer cópias da carta do secretário Sebastião e apensou outra sua e fez entregar em tudo que era relação, câmara, junta, comarca, ouvidoria. ${ }^{11}$ Essa ação aniquilou toda dúvida ou ressabios que rondavam as mentes e começavam a incomodar a paz pública. Sim, porque no dia $1^{\circ}$ de novembro, pessoas do povo e da nobreza disseram ter visto ou sentido coisas estranhas para as quais não tinham explicação. Na cidade da Bahia, pescadores descreveram que as águas tinham chegado a lugares aonde jamais chegara. No bispado de Pernambuco, pescadores foram em comitiva se aconselhar com algum religioso, pois tinham visto e sentido o mesmo que os baianos e temiam ser sinal dos tempos. No Rio de Janeiros, diversas pessoas que estavam em certas praias ou próximos alegaram ter ouvido "um grande ronco" vindo dos mares, que as fez correr, como toda sorte de animais, para o "mais alto dos montes". Por não ter sido experiência vivida por maioria, algumas dessas pessoas, na Bahia, em Pernambuco, no Rio de Janeiro, passaram a quase ser tidas por loucas ou insanas ou mentirosas. A carta do secretário Diogo Corte Real juntada à do conde dos Arcos desfez todo mal-entendido e prenúncios de confusão. Assim apreciou o arcebispo da Bahia meses depois. ${ }^{12}$ Mas, de maneira geral, abriram lastro para discussões e polêmicas.

A carta do secretário do conselho ultramarino, além de participar a "triste notícia da calamidade", que massacrara a corte e o reino, informava que ficava expressa a necessidade de reconstrução da vida em Portugal. Isso queria dizer, refazer Lisboa. Que queria dizer, com a imprescindível ajuda dos vassalos. A carta do conde dos Arcos distribuída aos governadores e administradores do Brasil já sugeria a necessidade, referente a cada um deles, da "eleição dos meios que se achassem mais proporcionados" para essa ajuda, com, nas palavras do conde, o "importante fim da reedificação dos edifícios públicos, sagrados e profanos da capital deste reino e seus domínios". ${ }^{13}$ Feito. Essa, que foi a primeira manifestação desse nobre senhor, que chegara à Bahia no dia 23 de dezembro de 1755 vindo de Luanda, marcaria, para o bem e mal, o conjunto de suas preocupações ao longo de seu mandato de vice-rei.

\footnotetext{
${ }^{11}$ Carolina Chaves FERRO - Terremoto em Lisboa, tremor na Bahia. Um protesto contra o donativo para a reconstrução de Lisboa. Niterói, 2009. (Dissertação apresentada à Universidade Federal Fluminense), p. 50.

${ }^{12}$ BNRJ - AMU - Bahia, 2077.

${ }^{13}$ Id., ibid.
} 
Também para servir de exemplo, a Bahia foi a primeira a se organizar para contribuir. A contribuição era voluntária. Mas precisava se manter regular. Era a norma do donativo. Uma oferta voluntária compulsória. Com essa pauta, teve lugar, no dia 30 de março de 1756, a sessão na câmara baiana. Como de costume, a discussão não foi pacífica. Mais ainda por se tratar de dinheiro. ${ }^{14}$ Mas, por fim, foi decidida a soma de 3 milhões de cruzados em 30 anos, na razão média de 100 mil por ano. Mais importante que os números, foi a estratégia, acordada, para ser mantida a regularidade do empenho. De toda transação envolvendo carne, água ardente, azeites e escravos, durante os trinta anos, seria subtraído um percentual. 160 réis, por exemplo, de cada arroba de carne, que tinha o preço médio de 640 réis. 160 réis para cada "canada" de água ardente. 80 réis para o azeite de peixe. No caso dos escravos, o montante era mais importante. Cada vivente chegado da Costa da Mina, Cacheu, Ilhas de São Thomé e do Príncipe e vendido na alfândega "renderia" 3 mil réis em donativo. O sistema de cobrança do imposto poderia variar. Os representantes de Cachoeira, por exemplo, sugeriram diminuir em 40 réis o imposto estipulado para cobrança dos açougues daquela vila. Nenhum problema. Assim se fez. Vários outros casos particulares foram acordados ali mesmo. Sergipe del Rey, Jacobina, Ilhéus, Porto Seguro foram alguns desses casos daquela sessão. De modo geral, ficou decidido que, no tempo, o povo de cada localidade poderia, através de seus juízes, vereadores, procuradores ou escrivães, modificar e melhorar o sistema da "maneira que julgasse mais conveniente". O importante era fazer cumprir a regularidade. ${ }^{15}$

Dias depois, o conde dos Arcos reuniu a ata e todos os documentos da sessão, fez copiar, e enviou para todos os governadores do Brasil para que lhes servisse de modelo. No dia 14 de maio de 1756, escreveu ao secretário do conselho ultramarino contando do "sucesso" da discussão na Bahia. No dia 5 de setembro, foi a vez de escrever ao secretário geral do reino dizendo que o "sucesso" cobria quase todo o Brasil. ${ }^{16}$

\section{Pernambucanos}

No dia 15 de novembro de 1756, Luís José Corrêa de Sá, antigo governador de Pernambuco, deu conta, a pedido extraordinário do secretário do conselho ultramarino, da posição de sua capitania. Luís Diogo Lobo da Silva, governador de fato, estava envolvido em

\footnotetext{
${ }^{14}$ cf. Carolina Chaves FERRO - Terremoto em Lisboa, tremor na Bahia, op. cit.

${ }^{15}$ BNRJ - AMU - Bahia, 2079.

${ }^{16}$ BNRJ - AMU - Bahia, 2297.
} 
problemas outros sem fim. Fazendo saber da liderança do vice-rei e do importante esforço dos baianos, fez, Corrêa de Sá, lembrar que Pernambuco não era a Bahia. Embora a lealdade e o amor dos pernambucanos ao soberano fossem fervorosos e inquebrantáveis. Sua contribuição à reconstrução do reino ficaria na casa dos apenas vinte mil cruzados por ano. As câmaras de Olinda e de Recife não conseguiram estabelecer maior valor ao donativo. Mesmo com importante esforço dos procuradores. $4 \$ 000$ réis ano foi o estipulado a cada senhor de fazenda. O percentual sobre os produtos ainda seria melhor estudado. O comércio e as contas públicas iam mal. Em nenhuma hipótese seguiriam os baianos. ${ }^{17}$ Não seguiriam, sobretudo, porque a situação geral do sistema de proteção e vigilância da capitania necessitava de reforma urgente. Junto com o parecer de Corrêa de Sá, o secretário do conselho ultramarino analisou a justificativa do governador Lobo da Silva. Lobo da Silva informara que a situação das fortalezas do Recife e de seus funcionários era inimaginavelmente péssima. Importante praça do império não poderia, reclamava o governador, estar exposta daquela maneira. A fortaleza Pau Amarelo estava, dizia, tão maltratada “que muita parte está no chão, e cheia de cascão, recomida de ferrugem, por não haver meios para lhes fazer reparos e se lhes dar suas mãos de tinta, e refrescar de tempo em tempo os canos das mesmas com sebo". A artilharia estava sem armas e sem munição. Muito da munição disponível não servia nas armas. Muitas das armas não serviam nem de bastão. Nas contas do governador, e também do exgovernador, seriam necessárias duas mil arrobas de pólvora, duas mil armas e mais pederneiras para lançar o sistema de defesa da praça e da fortaleza do Recife digno desse nome. A reação imediata do secretário Corte Real foi avaliar que tudo era possível, desde que nada, ou muito pouco, saísse de Lisboa. ${ }^{18}$ Reunidos em Lisboa no dia 2 de dezembro, o conselho resumiu as reclamações dos pernambucanos e elaborou um parecer para fazer saber o rei José. No sumário das informações, os conselheiros afirmavam ter nos armazéns reais apenas 2.172 espingardas e 1.758 quintais de pólvora. E que número sem fim de cartas vindas das diversas "provedorias das conquistas" reivindicava o mesmo. Sendo sua sugestão responder à demanda dos pernambucanos, pois a situação era realmente intrépida, mas de modo proporcional. Recomendaram remeter quinhentas espingardas e quinhentas arrobas de pólvora. ${ }^{19}$ Não se sabe se o rei José acatou o parecer do conselho. Oficializada a guerra franco-britânica, o secretário Sebastião preferiu nada fazer antes de ouvir atentamente o

\footnotetext{
${ }^{17}$ Luís José Corrêa de Sá, 15 de novembro de 1756. Consultas do conselho ultramarino. Bahia. Códice I-8,4,7. BNRJ-DH, vol. 92, pp. 7-10.

${ }^{18}$ Luís Diogo Lobo da Silva, 15 de maio de 1756. Consultas do conselho ultramarino. Bahia. Códice I-8,4,7. BNRJ-DH, vol. 92, pp. 5-7.

${ }^{19}$ Parecer do conselho ultramarino. 2 de dezembro de 1756. Consultas do conselho ultramarino. Bahia. Códice I8,4,7. BNRJ-DH, vol. 92, pp. 10-1.
} 
secretário Luiz da Cunha que vinha de Londres. Certos dessa situação, os conselheiros apensaram discreta sugestão ao parecer: "que Vossa Majestade mande ouvir o vice-rei da Bahia, que pela sua capacidade e experiência que tem com o governo de Pernambuco é digno de ser ouvido". 20

\section{A viagem da relação}

Nos dias 26 de fevereiro e 13 de outubro de 1751, o rei José assinou o decreto e regimento para a criação da relação na cidade de São Sebastião do Rio de Janeiro. O documento sugeria que a relação da Bahia era longe. Os trâmites, demorados. Os custos, altos. Os deslocamentos, perigosos. A relação no Rio de Janeiro seria, portanto, providencial. Cobriria além do Rio de Janeiro, São Paulo, Ouro Preto, Rio das Mortes, Sabará, Rio das Velhas, Serra do Frio, Cuiabá, Guyazes, Paranaguá, Espirito Santo, Itacazes e a ilha de Santa Catarina. ${ }^{21}$ Visto em frio, a decisão sustava a importância da relação da Bahia. Representava a redefinição do poder na colônia. A mudança gravitacional das autoridades. O começo do fim do isolamento do sul. O, enfim, reconhecimento do Rio de Janeiro. Visto em claro, sim e não. A decisão do rei de Portugal, dos Algarves, África, Senhor de Guiné, Etiópia, Arábia, Pérsia, Índia e Brasil envolveu variantes mais específicas. Nada contraditórias com a supremacia da Bahia. Despidas de rivalidades. Fruto de simples necessidade. Demanda de gente sedenta por justiça.

Seria redundante afirmar que a justiça praticada na colônia era precária. Precária, injusta e insuficiente. Com o aumento demográfico e a variação das áreas ocupadas a partir do advento do ouro, a discórdia passou a imperar. Aumento de pessoas e de vilas gerou aumento de problemas. Os documentos que regiam a exploração das minas davam margem a toda sorte de conflitos. Os principais foram de 1702 e 1718. Guardas-mores de minas e ouvidores de comarca entraram no bate-cabeça quotidiano.

Adiantava pouco eliminar o desafeto a bala. Embora muitos empregassem essa solução. Gente forte das minas recorria a advogados para resolver problemas de interpretação dos regimentos e crimes do ouro. O julgamento desses problemas e conflitos judiciais era

\footnotetext{
${ }^{20}$ Id.,ibid.

${ }^{21}$ Colecção da legislação novíssima do Ultramar. Lisboa: Imprensa Nacional/Companhia Tipográfica, 18951913. p. 102.
} 
submetido à relação. Aos homens de São Salvador. Das minas à relação, eram 300 a 700 léguas. Os autos demoravam a chegar. Muitos eram extraviados. Muitos eram confundidos. Sua multiplicação foi constante. Pelo excesso e pelos percalços, o tempo médio de resposta era de um, dois, três anos. Essa morosidade conjugada a corrente impunidade incitava delitos. Podia mais que mais podia. E quem podia, fazia sua lei. Com seus homens. Com seu ouro. Mas esse ouro permitia a ascensão econômica rápida de muita gente a uma certa condição mediana, média, remediada. Essa gente média ascendida e ascendente acreditava na lei. Melhor, só tinha, teria, na lei justiça. Por isso, juntaram forças na reivindicação. A justiça vinda da Bahia chegava, mas com retardo. Por 1723, advogados mineiros esboçaram solicitação de tribunal da relação para a Vila Rica. Nada. E pior: agravos e apelações e demora das decisões e extravios de autos aumentaram como aumentou o custo das operações. Isso conduzia a desistência das partes. Mais desistência, mais violência. Em junho de 1730, vereadores das câmaras de Vila Rica e Ribeirão do Carmo se uniram em petição ao conselho ultramarino solicitando relação no Rio de Janeiro. Por ser o núcleo de influência da região, poderia ter mais aceitação que Vila Rica ou algures. Com anuência da população, os vereadores propunham isentar a fazenda real de qualquer ônus. A gente de Vila Rica daria auxílio de 4.000 cruzados anuais. A de Ribeirão do Carmo, 3.000. Ano e tanto depois, a resposta do conselho ultramarino animou a todos. Embora não em absoluto. Em 7 de fevereiro de 1732, o parecer de Lisboa, que não dizia nem sim nem não, ordenava aos representantes de Rio de Janeiro, Minas Gerais e São Paulo que averiguassem mais vilas dispostas a contribuir. O Rio de Janeiro foi o primeiro a manifestar o interesse dos locais. Nos fins daquele ano, Cabo Frio, Santo Antônio de Sá, São Salvador, São João confirmavam empenho de 250.000 réis anuais. Em Minas Gerais e São Paulo se seguiu o mesmo. As petições com os números das contribuições voltaram para Portugal, mas jamais retornaram à colônia como decisão. Precisou chegar 1750 para se voltar a falar nisso. ${ }^{22}$

No dia 4 de novembro de 1750, o secretário Corte Real reuniu seus homens para decidir sobre a petição do guarda-mor das minas de Ouro Preto, Pedro Dias Paes Leme, referente à duplicação da relação. Nos vinte, trinta anos de discussão sobre o novo tribunal na colônia, muitos detalhes foram apurados. Dúvidas, retiradas. Convicções, afirmadas. O pedido de Paes Leme vinha respaldado numa já longa história de solicitações. Os argumentos eram praticamente os mesmos. A justiça estava longe. Difícil. Cara. Perigosa. Ausente. Isso

\footnotetext{
${ }^{22}$ Arno WEHLING \& Maria José WEHLING - Direito e justiça no Brasil colonial: o tribunal da Relação do Rio de Janeiro (1751-1808). Rio de Janeiro: Renovar, 2004. pp. 125-9. Graça SALGADO (Org.) - Fiscais e meirinhos. A administração no Brasil Colonial. 2. ed. Rio de Janeiro: Nova Fronteira, 1985. pp. 173-81.
} 
promovia prejuízos públicos e particulares aos envolvidos em questões mineiras. As soluções eram mais concretas. Consistentes. Definitivas. A nova relação seria no Rio de Janeiro. Dois palácios, do governador e do provedor da fazenda, foram sondados para sede. Casas nobres com quartos capazes foram indicadas para hospedar os ministros. O modelo da relação da Bahia foi finamente estudado. A relação do Rio de Janeiro não seria concorrente. Muito menos rival. Elas iriam se complementar. O projeto envolvia mútua relação. Dois dos dez desembargadores da Bahia seriam destituídos. Oito deveria ser o número deles servindo em cada uma das casas. Sendo que poderiam despachar nas duas. Duas relações. Dezesseis ministros. Ordenado de $600 \$ 000$ réis cada. Com acréscimo de $100 \$ 000$ réis ao chanceler. As câmaras de Minas Gerais e do Rio se prontificavam em arcar com esses valores. E ainda o aluguel das salas de conferência e os $350 \$$ réis pagos a guarda-mor, meirinho, porteiro e capelão. $^{23}$

O parecer do conselho foi terminal. Sugeria ao rei José a instalação da relação no Rio de Janeiro. Mesmo com o não-retorno do governador da capitania, Bobadela, sobre a viabilidade. Propunha que o tribunal no Rio fosse em tudo igual ao da Bahia. Dez ministros cada. E que as despesas fossem pagas pela fazenda real. Sem nada pedir ao povo. ${ }^{24}$ Isso inibiria o aumento da corrupção. Conferiria maior neutralidade à relação. Daria respeitabilidade aos ministros. Tiraria da vulnerabilidade completa os sem nome nem sangue.

O rei José acatou a postura do conselho. Em meses, a nova relação ganhou alvará para funcionar.

A mobilização das câmaras do sul foi intensa na solicitação de justiça. Sua gente estava disposta a pagar. Arcar com os altos custos de operação do tribunal. Exemplo genuíno de comprometimento e autodeterminação. Conseguiram o que queriam. Ganharam a relação. Nada parecido ocorreu no quesito capital. Ninguém pediu. Ninguém chorou. Ninguém mercadejou. Ela veio.

\footnotetext{
${ }^{23}$ Pedro Dias Paes Leme, 1750. Consultas do conselho ultramarino. Rio de Janeiro. BNRJ-DH, vol. 94, pp. 18692.

${ }^{24}$ Parecer do conselho ultramarino. 4 de novembro de 1750. Consultas do conselho ultramarino. Rio de Janeiro. BNRJ-DH, vol. 94, pp. 193-5.
} 


\section{Entre eles}

En politique comme en amour on ne sort de l'ambiguïte qu'à son detriment.

Pierre de Bernis

É perigoso quando se tem um inimigo fazer qualquer outra coisa que não matá-lo.

Ernest Hemingway

Perdoa-lhes: não sabem o que fazem. Lucas, 23, 34

Paris-Fontainebleau-Versailles, abril de 1763. Havia não mais que algumas semanas que o tratado de paz tinha sido ratificado por todas as partes. Os enviados extraordinários de Portugal, Espanha e Inglaterra ainda estavam na cidade. O conde de Bedford fechava as malas para voltar para Londres. Martinho de Mello e Castro e Girolamo Grimaldi ainda aguardavam segunda ordem de suas cortes quando chegou a notícia da morte do governador Bobadela no Rio de Janeiro e os detalhes da capitulação de Sacramento. Em Lisboa, esses ocorridos eram sabidos. Em Londres, bastante provável que não. Em Versailles, que desde o setembro próximo passado vivia em função da feitura do tratado, claramente não. A reação de Martinho de Mello e Castro não foi diferente da de seus colegas lusos e ingleses. Sentiu ter desaparecido um grande homem. Todos sabiam da importância do governador Bobadela para a administração portuguesa e todos sabiam da gravidade do assalto à colônia do sul ao processo de manutenção do equilíbrio do tratado que acabara de ser firmado. Envolvido de certa perplexidade, no dia 29 daquele abril, ele, Martinho de Mello, escreveu ao chanceler da corte inglesa, o conde de Egremont. O assunto não foi Bobadela, mas Sacramento. Em tom nada formal, escrevendo como quem escreve a um íntimo amigo mas sem perder a magia do verbo, apresentou ao colega inglês as sensibilidades do problema e sugeriu estratégia. Em sua 
concepção, o fim da guerra de sete anos não era o fim da aliança diferenciada entre suas cortes lusa e inglesa. Preocupações e dificuldades de uma seguiam concernindo à outra. Em seu ponto de vista, a Inglaterra precisava pressionar os espanhóis a devolver aos portugueses o que lhes pertencia. No estágio do conflito, apoiar com o envio de reforço armado ajudaria, mas possível não resolveria. Sua proposta era fazer um ultimato qual eles haviam feito a Portugal, mas com notas ligeiramente invertidas. Ou bem as terras eram restituídas ao Brasil ou bem seria promovido novo assalto a Havana. ${ }^{1}$ Sabendo da correspondência de Martinho de Mello com Egremont, pois por certo Martinho de Mello postara com cópia para Lisboa, Edward Hay, embaixador inglês em Portugal, escreveu imediatamente para Londres apresentando sua impressão de tudo que se passava. Em seu correio do dia 9 de maio, acentuou a consternação que tomara conta da corte lusa depois de apreender a notícia do desaparecimento do governador Bobadela. Contava que a mesma tristeza que o anúncio da morte do governador do Rio de Janeiro promovera no Brasil avançava pelos gabinetes dos secretários do rei José em Lisboa. ${ }^{2}$ Por esse momento, Grimaldi, não se sabe se por algum espião espanhol em Lisboa ou Londres, soube do conteúdo da carta de seu colega Martinho de Mello. Diferente de Martinho de Mello, que passara diversos anos em Londres e tinha boa relação com o alto corpo diplomático inglês, o contado de Grimaldi era unicamente o conde de Bedford. Foi a ele, portanto, que Grimaldi manifestou toda sua insatisfação e sensação de traição. Com o objetivo de fazer saber ao chanceler inglês, no dia 28 de maio, questionou a Bedford por que era que os portugueses não falavam diretamente com os espanhóis sobre assuntos que eram de portugueses e espanhóis. ${ }^{3}$ Egremont foi participado, mas os conflitos internos dos ingleses em Europa e Américas eram tamanhos que fingiu que não viu, ouviu. Martinho de Mello entendeu a provocação, mas não demorou a ser removido de Paris. O próprio Grimaldi foi instado a Madrid meses depois.

\section{Diplomatas}

Martinho de Mello, Bedford e Grimaldi estavam em uma missão extraordinária em Paris. Estavam ministros plenipotenciários. Possuíam, por assim dizer, todo o foro especial

\footnotetext{
${ }^{1}$ Martinho de Mello e Castro to Earl of Egrement. Paris, 29 de abril de 1763. The National Archives - Londres, State Paper Foreing - France, 78/256.

${ }^{2}$ E. Hay to Earl of Egrement. Lisboa, 29 de abril de 1763. The National Archives - Londres, State Paper Foreing - Portugal, 89/58.

${ }^{3}$ G. Grimaldi to Earl of Egrement. Paris, 28 de maio de 1763. The National Archives - Londres, State Paper Foreing - France, 78/257 - folio 90.
} 
que o momento exigia. A biografia deles se confundia com a história recente de seus países. Martinho de Mello foi quem substituiu Luiz da Cunha na embaixada de Portugal em Londres a partir de 1755-6 e teve papel decisivo em toda mediação política junto ao parlamento inglês da gestão da aliança luso-inglesa nos tempos de guerra. Bedford foi quem assumiu a embaixada da Inglaterra em Paris depois que a Espanha entrou na guerra em 1761. Grimaldi foi quem negociou, do lado espanhol, o pacto de família em Versailles. Na negociação da paz, os soberanos nos principais países envolvidos tinham sua atenção voltada para Paris. Simplesmente porque, da atuação de seus enviados dependiam os destinos de seus reinos. Fôra, sim, um momento diferenciado. Sobretudo, de modo geral, porque as cortes ainda não entendiam política externa como real problema de administração pública. ${ }^{4}$ Para além de resolver problemas e desentendimentos e alimentar suas cortes com informações e instruções, o enviado seguia necessariamente o decoro. Cuidava de cultivar boa relação com os locais. Dissimulação e hipocrisia eram regra. O contexto de alianças, mais ou menos fortes, entre os países dava a alguns enviados mais ou menos poder e importância e autonomia. Enviados portugueses na Inglaterra e ingleses em Portugal, franceses em Espanha e espanhóis em França, assim como portugueses na Espanha e na França e o contrário, durante aqueles anos de guerra e antes, influíam crescentemente na política dos países. Embora, muita vez, desprezados publicamente, internamente eram ouvidos e levados em conta tanto em seu país de origem, quanto onde serviam. Muitos deles tinham formação militar, alguns eram clérigos, outros, das leis. ${ }^{5}$ Mas o traço mais decisivo era o coeficiente de nobreza de cada um.

\section{Diplomacia}

Diante da multiplicação dos conflitos ao longo dos 1750s entre os reinos europeus, a consolidação de alianças foi decisiva. A aliança envolvia fidelidade e respeito. A gestão externa desses predicados nem sempre era pacífica. A desconfiança estava sempre presente. Mas inimigo comum era inimigo comum. Aquém e além-mar. A indefinição do tempo de conflitos multiplicava as animosidades e os rumores. As cortes desde Londres ou Versailles aguardavam e acompanhavam com imensa apreensão os cables de seus enviados. O caso dos enviados em Portugal tinha algo de especial. Em primeiro lugar, era imperativo conhecer a

\footnotetext{
${ }^{4}$ Jeremy BLACK - British foreign policy in the Eighteenth century: a survey. Journal of British Studies, 26, pp. 26-53, jan. 1987.

${ }^{5}$ Ricardo de OLIVEIRA - Política, diplomacia e o império colonial português na primeira metade do século XVIII. História: Questões \& Debates, n. 36, pp. 251-278, 2002.
} 
posição dos lusos com relação aos conflitos. A ascensão do dr. Sebastião a secretário de estado causou desconforto em toda parte. Certa imprevisibilidade tomou conta das impressões. No pós-sismo, essa incerteza ficou ainda maior. Era consenso a importância do Brasil na composição daquele reino. Assim como a centralidade do contencioso Sacramento em suas preocupações. Entretanto, não havia nenhuma ilusão ou ingenuidade da parte dos enviados em Lisboa com relação às prioridades de seus reinos. Portugal e Brasil eram apenas uma das peças daquele imenso mosaico de tensões que estavam perdendo o controle, especialmente, no além-mar - Américas do norte e central, Filipinas, costas africanas e das Índias. ${ }^{6}$ A importância de Portugal, portanto, no espectro global da guerra ia relativamente declinando. Entretanto, a guerra para Portugal foi se tornando crescentemente determinante. Isso aumentava a presença dos enviados estrangeiros na confecção das estratégias lusas. Muito especialmente os ingleses possuíam exclusividades nas secretarias do rei José. Tanto para contribuir na formulação de decisões como para tomar decisões pro-lusas. Enviados franceses e espanhóis eram tratados nos limites do decoro. Até serem expulsos ou enfaticamente convidados a sair, esses homens procuraram ampliar as relações, sobretudo, referentes ao comércio. Crises econômica e social assolavam os dois países. Não queriam nem podiam abdicar duma tão interessante fonte de negócios que incluía também e especialmente o Brasil. Esse interesse mesclado a cobiça impôs ao elo luso-inglês decisões ou o agir rápido para. Alguns desses episódios talvez mereçam destaque.

\section{Londres-Lisboa-Brasil}

No dia 14 de setembro de 1756, o enviado inglês na Madeira, Matthew Hiccox, escreveu para seu superior em Londres, sir Henry Fox, contando que naus francesas tinham atracado, inesperadamente, na ilha Grande, ao sul do Rio de Janeiro, com objetivo de tranquilizar a tripulação e rumar para a Índia. ${ }^{7}$ Desde Madeira, essa informação era corriqueira. Não representava mais que mais uma notícia. Mais um expediente. Em Londres, esse comunicado foi traduzido em dupla preocupação. Era preciso reforçar a proteção das rotas para a Índia. Era imperativo reforçar a proteção do Brasil. Proteger o Brasil teria dois significados. Inibir a presença de naus inimigas e avigorar a aliança com Portugal. Portugal

\footnotetext{
${ }^{6}$ Paul KENNEDY - The Rise and Fall of the Great Powers. Economic Change and Military Conflict from 1500 to 2000. New York: Random House 1987. pp. 147-77.

${ }^{7}$ M. Hiccox to H. Fox. Madeira-Portugal, 14 de setembro de 1756. The National Archives - Londres, State Paper Foreing - Portugal, 89/50.
} 
vivia o imediato pós-sismo. Carestia e debilidade em todas as áreas. O Brasil era o espaço português dos mais prósperos. Ajudar a salvaguardar era a missão dos aliados. Os relatórios de Abraham Castres, embaixador inglês em Portugal, indicavam a desolação lusa. Mais de meio ano depois do fatídico $1^{\mathrm{o}}$ de novembro, a sensação em Lisboa era de fim do mundo. ${ }^{8}$ Edward Hay, então cônsul inglês em Lisboa, foi participado do informe de Hiccox e das intenções de Londres. Imediatamente se pôs a estudar a situação da marinha portuguesa. Seu interesse era saber que tinha restado e avaliar sua capacidade de combate. Nesse meio tempo, Castres morreu e Hay foi elevado a embaixador. Como embaixador, sua preocupação seguiu a mesma. Entretanto, problemas cotidianos o absorviam. Ingleses de Lisboa e do Porto estavam descontentes com as políticas do secretário Sebastião. O secretário Sebastião estava descontente com as manifestações dos ingleses. Cabia ao embaixador Hay, como tinha sido com Castres, contemporizar. Em Londres, Willian Pitt assumia a chancelaria em lugar do sir Henry Fox. Pitt entendia que era preciso dar agilidade ao apoio e à proteção de Portugal e Brasil. Com esse intuito, mandou marinheiros diretamente ao Brasil. Os escolhidos foram ingleses que serviam em rotas das Índias. Sua função seria ir fazer o trajeto inverso que os franceses estavam fazendo, aportar na capital do Brasil e avaliar as suscetibilidades daquela parte de Portugal.

Benjamim Keene foi um dos responsáveis pela expedição. Chegou à Bahia com mais quatro emissários. Não se sabe quanto tempo ficou, nem o que viu e estudou e com quem falou. Keene, que estava com a saúde debilitada, disse a Hay que daria o quadro da situação somente pessoalmente em Lisboa e, em seguida, em Londres. As águas estavam mais perigosas que nunca. A guerra tinha invadido todos os seus sentidos. Mas não se furtou a contar a última novidade que tinha sido a visita do conde d'Aché ao Rio de Janeiro. O horror que esse esquadrão francês causou aos moradores foi rapidamente sabido na cidade da Bahia. Não se sabia muito bem que fazer. Por intermédio de Keene, Hay foi, provavelmente, um dos primeiros em Portugal a saber das naus d'Aché nas costas fluminenses. ${ }^{9}$ Mesmo que as investidas francesas não fossem contra o Brasil, para Hay e Pitt era necessário neutralizá-las. Uma das estratégias foi forçar o aumento do comércio com o Brasil. Frotas inglesas serviriam para mostrar aos inimigos a força da aliança entre os reinos. Com isso, intimidar qualquer tipo

\footnotetext{
${ }^{8}$ List of British subjects killed by the earthquake at Lisbon Nov. 1, 1755. The National Archives - Londres, State Paper Foreing - Portugal, 89/50.

${ }^{9}$ E. Hay to W. Pitt. Lisboa, 9 de dezembro de 1757. The National Archives - Londres, State Paper Foreing Portugal, 89/51.
} 
de ataque e atacar caso necessário. Pelo sim pelo não, em 1760, as exportações de Inglaterra para o Brasil via Portugal chegaram a representar quase $50 \%$ do conjunto das importações. ${ }^{10}$

No dia 19 de maio de 1759, o embaixador Hay finalmente enviou seu relatório sobre a marinha portuguesa. Não informou mais que o que conhecido de Londres e de todos. Tudo ia muito mal. Seu maior espanto, no entanto, era com a economia. Como também Londres e todos sabiam, Portugal tinha "economic situation bad". E tendia a ficar ainda pior. Segundo informava, tinha quase um ano que não chegava dinheiro do Brasil. Nenhum navio sequer. $\mathrm{E}$ essa era uma péssima novidade. ${ }^{11}$ A importância da colônia do Brasil para Portugal era um consenso para todos os enviados. Muito embora Goa, Macau, Moçambique, Angola e Índia sempre viessem referidas como complementos decisivos. Praticamente todos os enviados ficaram impressionados com o volume de ouro, prata, diamantes e dinheiro em espécie que aquela colônia fazia fazer chegar ao porto de Lisboa. Não menos que no mínimo 10 milhões de cruzados em cada embarcação. Como parte desse montante pertencia à Inglaterra, cabia aos ingleses uma preocupação sempre especial com a situação do Brasil.

Quando da morte do rei João, grande comoção cobriu a maior parte dos reinos europeus. A ascensão do rei José e a nomeação do secretário Sebastião causaram, de fato, grande apreensão. Malta, Turim e Nápoles enviaram representantes exclusivos para o coroamento do novo rei. Londres e Versailles orientaram seus enviados a observarem cautelosamente os primeiros passos do novo governo. Muito especialmente os do novo secretário de estado. Desde os primeiros momentos, muita especulação foi sendo gerada em torno dos dois. ${ }^{12}$ A opinião interna sobre o rei José não era satisfatória. Como não o era acerca do rei João em seus últimos momentos. O tratado de Madrid tinha sido o grande acontecimento. A capacidade do novo rei em executá-lo punha dúvidas. Ao mesmo tempo, enviados franceses e ingleses em Lisboa alimentavam dúvidas com relação ao destino do Brasil. No início de 1751, Castres enviou um primeiro relatório mais substantivo. Comentava a ampla aceitação ocorrida pela intenção do rei João em tornar mais clara a taxação do ouro e

\footnotetext{
${ }^{10}$ Augusto A. Alves SALGADO - O poder naval português no Atlântico Séculos XVI a XVIII. In.: ACTAS do Congresso Internacional Espaço Atlântico de Antigo Regime: poderes e sociedades. Lisboa, 2005.

${ }^{11}$ E. Hay to W. Pitt. Lisboa, 19 de maio de 1759. The National Archives - Londres, State Paper Foreing Portugal, 89/51.

${ }^{12}$ A. Castres to R. N. Aldworth. Lisboa, 8 de dezembro de 1750. The National Archives - Londres, State Paper Foreing - Portugal, 89/47.
} 
do açúcar vindos das colônias. No entanto, houve vasta perplexidade com a indicação do irmão do secretário geral para o governo do Maranhão. Isso denotava indesejada crescente influência do dr. Sebastião sobre o rei. ${ }^{13}$ Com os anos, a perplexidade acerca dele só fez crescer. No mesmo momento que o embaixador Hay comunicava que o tesouro vindo do Brasil tinha minguado, pois navio algum aportara nos últimos meses, reafirmava que o povo de Portugal considerava que o secretário Sebastião era tido como "ditador tirano" absoluto. ${ }^{14}$ Justamente nesse momento chegou o novo enviado francês a Lisboa. O conde de Merle.

Com Merle chegou a Portugal o rumor de que os franceses estavam preparados para invadir a Amazônia e todo o estado do Maranhão. Rumor ou não, o enviado inglês notificou à sua corte.

\section{Segredos}

Instalado em Lisboa, Merle enviou sua primeira notícia para Versailles no dia 22 de janeiro de 1760. Dizia estar bem. Tranquilo. Bem acomodado. Duas situações lhe incomodavam: o ouro e os tolos. Com tom rancoroso, informava que o navio holandês acabara de sair do porto de Lisboa carregado com 6 milhões em ouro vindo do Brasil. Sua indagação era precisa. Queria entender por que algum desse ouro não poderia ir para sua majestade o rei da França. Parte da resposta foi no seu primeiro relatório mais substancioso postado dois dias depois, no 24 de janeiro. ${ }^{15}$ Nele, Merle fala dos tolos. Portugueses e espanhóis que quase caíram na artimanha inglesa de abocanhamento da América meridional em 1752-4. Seu relato veio em momento oportuno. O rei Fernando da Espanha vinha de morrer. Sobre seu sucessor, o rei Carlos, a indefinição dos contenciosos luso-espanhóis nas Américas tendia a aumentar. O secretário Ricardo Wall havia muito apenas aguardava o momento para implodir o tratado de limites de 1750. A morte da mulher do rei Fernando, dona Maria Bárbara, irmã do rei José de Portugal, foi o início. A decorrente demência e morte do rei espanhol foi o avanço certeiro. A ascensão do rei Carlos representou forte simples detalhe. A raiz dessa aversão ao acordo de 1750 foi o que Merle descortinou com perícia.

\footnotetext{
13 A. Castres to Duke of Bedford. Lisboa, 17 de abril de 1751. The National Archives - Londres, State Paper Foreing - Portugal, 89/48.

${ }^{14}$ E. Hay to Willian Pitt. Lisboa, 19 de maio de 1759. The National Archives - Londres, State Paper Foreing Portugal, 89/51.

${ }^{15}$ Quadro elementar das relações políticas e diplomáticas de Portugal com diversas potências do mundo desde o princípio da monarquia portuguesa até os nossos dias ordenado e composto pelo visconde de Santarém. Lisboa: Typ. da Academia Real das Sciencias, tomo 6, 1864. pp. 187-95.
} 
Estava de ruim a péssima a situação econômica de todas as potências do espaço europeu. De Inglaterra e França, muito especialmente. Vizinhos na Europa e em várias conquistas, os reinos inglês e francês lutavam desbragadamente pela autoafirmação. Os custos militares dessa empresa tinham lhes arruinados os cofres. Revalorização de seus produtos conjugada a ampliação de fluxos comerciais era das primeiras escolhas. A opção mais plausível era o aumento de seus negócios com o consequente aumento de vassalos. Mais vassalos era sinônimo de mais territórios. A América do sul era o ponto mais favorável. Mas mais que armas, era preciso inteligência. A crescente aproximação de França e Espanha na passagem dos 1740s aos 1750s levou os ingleses a recear a perda de Gibraltar. Gibraltar atrapalhava o avanço de franceses e espanhóis nos mercados do Mediterrâneo. Espanha com expedientes francesas poderiam reivindicar fortemente essa possessão. Em caso de avanço armado inglês direto contra Espanha ou França, Gibraltar seria das primeiras a cair. O plano inglês foi, portanto, conquistar espaços americanos usando aliados lusitanos. Convencidos da nebulosidade do tratado de 1750, os ingleses decidiram influir na sua implementação. Enviaram agentes a Lisboa e a Madrid para persuadir pessoas influentes. Dona Maria Bárbara foi objeto de diversas reuniões secretas com ingleses. Em Portugal não foi preciso muita discrição. Os homens falaram direto com o rei José. A proposta era fazer avançar o processo de cessão, por parte de Portugal, de Sacramento aos espanhóis e, ao revés, que passassem imediatamente ao lado luso as sete colônias às margens setentrionais do rio da Prata. Consumado o acordo, Portugal, e Inglaterra, teria incremento de 300 mil vassalos. O argumento dos ingleses para os espanhóis reforçava a importância de Sacramento como núcleo de escoamento dos minérios coloniais. Sua sugestão era, em se fazendo o trato, ajudar a eliminar de vez com o contrabando. Participado do projeto, o rei Fernando enviou correspondência ao governador de Montevideo reivindicando parecer. Concomitantemente, ingleses e portugueses, inclusive residindo no Brasil, começaram a pressionar esse governador a dar as melhores informações para o sucesso rápido do acordo. Foi o que fez. Apreciado o parecer favorável vindo das Américas, o rei Fernando enviou procurador mais dois engenheiros para executar, o quanto antes, a troca. O procurador de Madrid foi direto a Buenos Aires com cartas de apresentação e recomendação. O governador de Buenos Aires se opôs em tom grave. Escreveu ao rei Fernando justificando ser imenso engano. Um equívoco. Uma armação. Nada daquilo poderia se consumar. Notou que nada se deveria fazer na região sem ouvir os padres do Paraguai; pois, o governador de Montevideo pouco ou nada sabia. E, 
certamente, foi por isso que entraram em contato primeiro e direto com ele. Informou que a margem que se queria dar para os portugueses, e ingleses, estava frondosamente povoada de árvores do melhor tipo de madeira para construção naval e civil. Isso facilitaria que ingleses, e portugueses, se armassem in loco. O que fragilizaria sobremodo a presença espanhola na região. Uma vez nessa área, e especialmente ao norte do rio Paraguai, os adversários estariam a dez léguas de Potosí e rapidamente se fariam os "senhores das minas d'ouro". Não sobrando nada para ser contrabandeado ou exportado por Sacramento. Com isso, o plano inglês fôra desmascarado.

Muita gente em Lisboa, Madrid e Londres não esteve a par do plano. Mas as consequências de seu desmascaramento foram rapidamente percebidas. No dia 23 de fevereiro de 1754, o embaixador Castres noticiou ao seu chanceler a situação no Prata vista desde Portugal. Disse ao chanceler Amyand que deveria de ter cerca de 20 mil homens nas reduções do Paraguai de armas nas mãos contra brasileiros, portugueses e ingleses. Sendo a maior parte de ameríndios que se opunham fortemente a serem transferidos para Portugal. ${ }^{16} \mathrm{O}$ papel dos jesuítas foi decisivo. O correio do cônsul inglês em Lisboa, no dia seguinte, foi ainda mais enfático nesse sentido. "The Jesuits are reported to be stirring up the Amerindians against giving any Spanish territory to the Portuguese". ${ }^{17}$

Daí a pouco mais de cinco anos, os jesuítas seriam expulsos dos domínios. Um pouco mais à frente, foi a vez do tratado de 1750.

\footnotetext{
16 A. Castres to C. Amyand. Lisboa, 23 de fevereiro de 1754. The National Archives - Londres, State Paper Foreing - Portugal, 89/48.

${ }^{17}$ G. Crowle to C. Amyand. Lisboa, 24 de fevereiro de 1754. The National Archives - Londres, State Paper Foreing - Portugal, 89/49.
} 


\section{Antonio Gomes Ferrão Castelo Branco}

Quem é pobre não tem vícios. Antonio Gomes Ferrão Castelo Branco

'Que duas gerações há só diferente, Virtude, e Vicio; tudo mais é engano.'

Cipriano Barata, Desengano ao público.

Homine imperito numquam quidquam injustius.

Terêncio

Pedro de Unhão Ferrão Castelo Branco foi o primeiro representante da linhagem dos Castelo Branco na Bahia. Durante anos fôra ouvidor geral do Rio de Janeiro. Portador de personalidade forte e gênio difícil, acabou contraindo numerosos desafetos e enormes dificuldades para exercer sua função. Diante da situação, aplicou para integrar a suprema corte de justiça. O tribunal da relação. Em funcionamento apenas na Bahia. Conseguiu indicação em 1689, ano em que se mudou para São Salvador da Bahia de Todos os Santos. Na relação, foi pouco a pouco se afirmando como importante desembargador. $\mathrm{Na}$ sociedade baiana, não demorou a adquirir prestígio e reputação. Entrou rapidamente na rotina local. Especialmente afirmando objetivos pessoais - econômicos e sociais. Comprou terras, gado, fazendas, escravos. Casou-se com a lisboeta Damiana Francisca da Silva, filha da elite instalada. Construiu a "mansão da praia" - o hodierno Solar do Unhão que segue impactante pela suntuosidade. Com seus salários de desembargador e lucros de seus negócios somados ao dote de sua mulher, legou aos seus herdeiros considerável fortuna. Maria Francisca Castelo Branco e Antonio Castelo Branco, seus filhos, ficaram incumbidos de preservar e multiplicar o dinheiro, as posses e a força do nome. Maria Francisca se casou com Antonio Gomes Ferrão. Dessa união nasceu Alexandre Gomes Ferrão Castelo Branco, quem efetivamente deu seguimento à glória de Pedro de Unhão que morrera em 1738. Recebeu, Alexandre Gomes, a fidalguia do avô e foi tornado, ainda moço, cavaleiro da ordem de cristo. Em seguida, assumiu 
a patente de coronel de milícia. Dos 1730s aos 1740s, ampliou consideravelmente os domínios materiais e simbólicos da família. Comprou imensas extensões de terras às margens do São Francisco e se tornou um dos irmãos da Santa Casa de Misericórdia. Casado com Maria Cardoso de Oliveira, filha de riquíssima família baiana, teve quatro filhos. Dentre os quais, Antonio Gomes Ferrão Castelo Branco. Como a maior parte dos homens de poder daquele mundo, e em todos os outros mundos, Alexandre Gomes possuía muitos adversários e inimigos. Alguns eram simples rivais de sua família. Outros o odiavam e lhe queriam num caixão. Em algum momento dos 1740s, por razões ainda pouco fiáveis, mas provavelmente relacionadas a esses contrários, abandonou a cidade da Bahia. Mesmo sendo naquela cidade, além de sua casa e família imediata, os núcleos operacionais e referenciais de reprodução de sua vida. O porto, os negócios, a política, a religiosidade, a intelectualidade, muitos amigos. Em sua ausência, Alexandre Gomes deixou tudo aos cuidados de Antonio Gomes. Instalado nas distantes margens do São Francisco, manteve correspondência permanente com seu filho que, por sua vez, fazia o mesmo com todos os links de sua vida - família, negócios, amigos, relações e gente da relação. O registro dessas cartas foi deixado em uma espécie de anotador pessoal, o borrador. ${ }^{1}$ Alguns aspectos daquela sociedade baiana, a partir das impressões desse borrador, vão mostrados a seguir.

\section{Leitores}

O Borrador de Antonio Gomes Ferrão Castelo Branco é um manuscrito de mais de 220 folhas com a cópia de cartas de enviadas e recebidas por Antonio Gomes de agosto de 1749 a março de $1759 .^{2}$ Quem primeiro localizou e analisou o documento em profundidade foi Mary Del Priore. Seu Ritos da vida privada foi nele enormemente baseado. Em seguida, István Jancsó passou alguns anos meditando sobre o manuscrito e lhe fez referência em duas ocasiões: Independência, independências e Brasil e brasileiros. ${ }^{3}$ Sem entrar no mérito das

\footnotetext{
${ }^{1}$ Admissão de Pedro de Unhão Ferrão Castelo Branco à Santa Casa de Misericórdia da Bahia. Bahia, 06 de abril de 1732 - SCMBA - Tr. Ir. 504, L. 3, 355 (614v). Genealogia baiana ou o catálogo genealógico de fr. Antônio de S. Maria Jaboatão, adaptado e desenvolvido por Afonso Costa. RIHGB, tomo 191, p. 198, abr./jun. 1946. Stuart SCHWARTZ - Burocracia e sociedade no Brasil colonial. A suprema corte da Bahia e seus juízes: 1609-1751. São Paulo: Perspectiva, 1979. pp. 251 ss.

${ }^{2}$ Borrador de Antonio Gomes Ferrão Castelo Branco. Biblioteca Guita e José Mindlin.

${ }^{3}$ Mary del PRIORE - Ritos da vida privada. In.: Laura de MELLO E SOUZA (Org.) - Cotidiano e vida privada na América portuguesa. São Paulo: Companhia das Letras, 1997. István JANCSÓ - Independência, independências. In.: István JANCSÓ (Org.) - Independência do Brasil: história e historiografia. São Paulo: Hucitec, 2005. Istvan JANCSÓ - Brasil e brasileiros - Notas sobre modelagem de significados políticos na crise do Antigo Regime português na América. Estudos Avançados, n. 22 (62), 2008.
} 
interpretações de Del Priore e Jancsó, noções de crise e transição estão no cerne de suas abordagens. Ambos identificam determinada crise estrutural daquela sociedade de ancien régime em vias de transição para algo ainda indefinido nas mentes e nos dias dos viventes. Ambos também observam determinada crise econômica e social na estrutura da sociedade baiana que precipitaria sua decadência com a transição da capital da Bahia para o Rio de Janeiro em 1763. Sem reduzir grosseiramente a abordagem deles - que, em verdade, representam duas muito interessantes e importantes avaliações da história e da vida na porção americana do império português naqueles meados dos setecentos - , ambos, consciente ou inconscientemente, elegem 1763 a referência principal da transição. Como se a mudança da capital fosse a constatação da crise da e na Bahia. E, mesmo que não de modo explicito, ainda fica a impressão de que a agonia e as dificuldades dos Castelo Branco poderiam refletir e ser reflexo da crise e transição social e estrutural que, supostamete, se vivia. Tendo a acreditar que parece que não foi bem assim.

\section{Em nome do pai}

No dia 8 de junho de 1752, Antonio Gomes escrevera mais uma carta ao seu pai, Alexandre Gomes. O assunto versava sobre dinheiro e negócios, família e trabalho. Negócios e trabalho de toda sorte eram essenciais para garantir dinheiro suficiente para o "luzimento da casa" e da família. Vender e comprar terras. Comprar e vender escravos. Negociar açúcar, bois, madeira. Manter as corriqueiras boas relações com ministros. Falar e ter a confiança de religiosos. Cobrar devedores. Aliciar credores. Arranjar bons casamentos para parentes. Respeitar os amigos. Corromper conhecidos influentes dando dinheiro e "mimos". Não era outro o objetivo de Antonio Gomes senão mostrar ao pai seu esforço naquilo que não era "pequena proeza" que era continuar "conservando as posses" (fl. 43f). Essas posses consistiam em bens tangíveis e intangíveis. Para além das terras e do gado, o nome da família precisava continuar sendo honrado. Nesse intuito, duas estratégias foram empregadas: bons casamentos e bons cargos públicos. Ainda durante os 1740s, Antonio Gomes contraiu casamento com Maria Felícia de Albernás que era filha do ouvidor de Sergipe e desembargador da Bahia Tomás Feliciano Albernás. ${ }^{4}$ Durante os 1750s, reivindicou promoção em cargos militares, muita vez, acumulando funções. Em 1755, foi vereador, para

\footnotetext{
${ }^{4}$ Stuart SCHWARTZ - Burocracia e sociedade no Brasil colonial, p. 282.
} 
angariar mais visibilidade e poder de negociação. ${ }^{5}$ Em toda essa movimentação, que nem sempre fôra tranquila, Alexandre Gomes esteve presente.

Ainda não se sabe ao certo quando e por que Alexandre Gomes foi se instalar em suas propriedades às margens do rio São Francisco deixando seu filho no comando na capital. Embora Jancsó insista que Alexandre Gomes fugira da cidade por "ter entrado em rota de colisão com o vice-rei André de Melo e Castro"6, o confronto das conjunturas políticas da época e das próprias impressões do borrador enfraquecem a hipótese do nobre historiador. Contrária a toda insinuação e aparência, a influência dos Castelo Branco continuaram decisivas na praça da Bahia e na corte em Lisboa. Alexandre Gomes teve correspondência particular e afável com os sucessores de Melo e Castro, o conde de Athouguia e o conde dos Arcos. De todo modo, desde os primeiros registros do borrador, agosto de 1749, Alexandre Gomes esteve ausente.

No dia 4 de outubro de 1749, Alexandre Gomes escreveu para seu irmão Thomas da Costa de Almeyda Castelo Branco pedindo que intercedesse para que Antonio Gomes fosse promovido a capitão de infantaria (fls. 3-4). Havia mais de nove anos que Antonio Gomes servia como oficial de ordenança. Esgotado e isolado, Antonio Gomes não suportava mais o "subalterismo" de "postinhos" (fls. 7-9). Alexandre Gomes então pedia que Thomas da Costa articulasse toda sorte de contato e artifício "nem que custe algumas moedas" (fl. 3). Em menos de um ano, Antonio Gomes foi elevado a tenente. Essa promoção teve a intermediação do novo vice-rei, o conde de Athouguia, que já estava pela Bahia (fls. 6v e 7f). Antonio agradeceu, mas não se deu por satisfeito. Continuou reivindicando a patente desejada. Por isso, no dia $1^{\circ}$ de abril de 1750 , escreveu a Dionísio de Carvalho expondo suas razões. E, como seu pai, fôra enfático ao afirmar estar preparado para agradecer com bons "mimos" aos que ajudassem em sua promoção (fls. 7-9). A essa altura, dezenas de contatos haviam sido estabelecidos. Pessoas em diversas partes do Brasil e de Portugal e mesmo da Índia estavam "prontas" para colaborar. No início de 1752, foi elevado a sargento-mor de auxiliares do regimento que guardava a marinha da Torre de Garcia d'Ávila. Não desgostou de tudo, embora o destacamento estivesse longe da cidade. No entanto, exigiu honrarias militares, soldo nivelado aos das demais capitanias e, em seu caso particular, soldo especial tendo em

\footnotetext{
${ }^{5}$ BNRJ - AMU - Bahia, 1951.

${ }^{6}$ István JANCSÓ - Brasil e brasileiros, p. 262.
} 
vista seus anos de serviços prestados "à farda" (fls. 34f e v). Mesmo não sendo o resultado desejado, essa nomeação levou pai e filho a perceberem uma "ampliação gradual" de seu poder de influência na praça da Bahia sob a direção do conde de Athouguia. Por isso, de imediato, Alexandre Gomes enviou carta pessoal ao vice-rei solicitando para si a patente de sargento-mor da vila de São Francisco (fls. 63f-68v). Não se sabe se Alexandre Gomes conseguiu a nomeação. Do lado de Antonio Gomes, mesmo nomeado, não assumiria enquanto não lhe fossem garantidas as promoções requeridas. Em 1754, ainda estava discutindo no senado da câmara sobre as condições (fl. 93f.). Queria que seu soldo fosse dobrado. A essa altura falava diretamente com o vice-rei. $\mathrm{O}$ que não se diferenciou com a vinda do conde dos Arcos (fl. 161). Nos anos que se seguiram foi finalmente nomeado capitão da infantaria e passou a requerer todos os "soldos atrasados" (fl. 182).

Toda essa operação, ao longo de quase dez anos, envolveu muitos "mimos". "Muitas moedas" foram necessárias para consolidar os objetivos. Portadores de cálculo de risco aguçado, pai e filho promoviam toda sorte de negócio para conseguir as "moedas" para subornar e corromper os homens de poder. Muita vez, o retorno era demorado e isso forjava tensão na relação dos dois. Da mesma forma que emprestavam, tomavam dinheiro emprestado. Da mesma forma que, muita vez, não pagavam seus credores, recebiam calotes de seus devedores. Tentavam, de todo modo, diversificar suas áreas de atuação e seus contatos. Afinal, "bom era fazer negócio por todos os caminhos" (fl. 77v).

\section{Damaso}

Damaso Gomes da Cruz. Amansador de cavalos. Homem de confiança dos Ferrão Castelo Branco. Ajudante preferido de Antonio Gomes. Em meados de 1756, foi-se embora levando um redomão e pertences de seus senhores. Ninguém jamais teve dele, deles, notícias. Fugiu e desapareceu. Alexandre e Antonio Gomes ficaram irados e frustrados. Irritadíssimos e frustradíssimos. Não pelos bens que o mulato Damaso levou. Mas pela lealdade que se quebrou. O mercado de amansadores de cavalo era abundante. A própria quantidade de cavalos disponíveis para compra e venda também. Assistentes fiéis, ordeiros, competentes era raridade. Damaso reunia todos esses predicados (fl. 144v). Além do mais, era tido como ente da família. Alguém de casa. Uma referência masculina de respeito e dignidade para os demais criados. E mesmo para os escravos. Naquele mundo baiano e brasileiro, desentendimentos patrão-criado eram comuns. Fugas, constantes. Especial e majoritariamente de escravos. Os 
Ferrão Castelo Branco já tinham por muito experimentado e vivenciado. Ora entre os seus. Ora entre os de seus conhecidos. Entre 1751 e 1752, a família de Antonio José Victoriano Borges, muito próxima dos Ferrão Castelo Branco, viveu drama similar. Seu "escravo de confiança" fugira (fls. 30v, 31f). Como de uso, todos os amigos e conhecidos, autoridades ou não, foram informados. Toda informação seria recompensada. Para o caso Damaso, Antonio Gomes passou mais de dois anos contatando pessoas. Elegeu inclusive o padre José da Cunha como seu procurador na ocorrência. O desejo de vingança não tinha preço. A traição de Damaso não poderia passar sem punição.

A ação de Antonio Gomes era resultado de múltiplas variantes. A lealdade interrompida feria sobremodo a autoridade de pai e representante maior da casa que Antonio Gomes agora acumulava. Localizar e castigar o prófugo eram uma questão de honra. Estatuto muito caro naquele mundo nitidamente patriarcal e religioso, de aparências e distinção. ${ }^{7}$ Ninguém da família, exceto o pai Alexandre Gomes e um e outro tio, foi comunicado do incidente. As irmãs de Antonio Gomes, alojadas em conventos em Portugal, e seu irmão Pedro, caso tenham tomado conhecimento foi por boca de outros.

\section{A bolsa e a vida}

Em todo período de ausência de Alexandre Gomes, Antonio Gomes seguiu mercadejando e administrando os interesses da família. Esse ofício envolvia compra e venda de rês, madeira, cavalo, terras, escravos, farinha, feijão. Negociação de dívidas. Execução de devedores. Identificação de credores. Arrendamento de engenhos. Essa condição exigia atenção, informação e malícia. Os negócios e os patrimônios se alastravam por toda a capitania da Bahia, mas dependiam do conhecimento e da percepção das tendências d'alémmar. Especialmente Europa, Costa da Mina e Índia. O porto da cidade era o local ideal para saber das novas. Antonio Gomes frequentemente ia ou mandava ir. O seu olheiro mais constante era João Dias da Cunha. As novidades não eram apenas escravos ou produtos. Embora a qualidade dos escravos chegados e a quantidade de produtos fossem informação de importância. Antonio Gomes aguardava com certa ansiedade as cartas das irmãs e dos amigos e parentes. Nessas cartas, vinham as resenhas dos assuntos internacionais em primeira mão. $\mathrm{Ou}$, ao menos, deveriam vir. Entretanto, nada do que foi definidor para os administradores em Lisboa apareceu nessas cartas. Nem o terremoto. Nem o atentado ao rei. Nem o caso dos

\footnotetext{
${ }^{7}$ Gilberto FREYRE - Casa-Grande \& Senzala. 51. ed. São Paulo: Global, 2006.
} 
Távoras. Nem a cruzada aos jesuítas. O imperativo para Antonio Gomes era sua família. E isso já envolvia muita dedicação. Mesmo envolvido em cargos e ocupações "públicas”, os Ferrão Castelo Branco, ao menos em suas correspondências, não discutiram conjunturas. Fossem internas ou externas. Tinham imenso senso prático. Esse pragmatismo levou Antonio Gomes a reprochar seu irmão Pedro quando este solicitava permissão para compra de cavalo. “Se V. M. (sem moedas) pode negociar cavalo murzelo bom fora; porém quem é pobre não tem vícios; procure-nos antes cavalo singelo" (fl. 70f.).

Os Ferrão Castelo Branco não eram pobres. Eram convictos disso. O pecado mais imperioso era ser vulgar. O vulgar vivia no império dos vícios. Possuir cavalo singelo, com ou sem moedas, era uma maneira de manter a discrição. De ser discreto. De fugir do vício e dos olhares. Pedro Ferrão, irmão mais moço de Antonio Gomes, administrava um dos sítios da família. Estava longe e sozinho. Tinha Antonio Gomes como referência para suas ações e atitudes. Antonio Gomes, por seu turno, era pedagógico. "Quem é pobre não tem vícios”. Ao mesmo momento, para com as irmãs, em convento em Lisboa, Antonio Gomes nada interferia. Sua função era apenas fornir as provisões.

\section{Crises?}

Os dias de Antonio Gomes administrador dos Ferrão Castelo Branco foram agitados. Instáveis. Difíceis. Pouco provável que por crise econômica, financeira ou por decência. Os 1750s foram anos de decisão. Deixou de ser fácil viver na Bahia. O comércio ficou mais e mais disputado. Os mercados exteriores, rigorosos. Bandeirantes baianos acharam ouros e diamantes e investiram massivamente na capital. Houve real multiplicação dos interesses na cidade da Bahia. A cidade foi ficando pequena. Muita riqueza. Muita fortuna. Muita gente rica em fortunas. Era mais que nunca importante se manter na cidade. $\mathrm{O}$ diferencial para isso era a inteligência. Dinheiro e influência, bem ou mal, todos tinham. Nas contas de José Antonio Caldas, nesse decênio, a capitania comportava mais de 150 senhores de engenho e a capital, mais de 120 homens de negócios. Senhores de engenho, não raro, tinham alambiques e produziam cachaça. Além de plantar cana, tinham gado, cultivavam arroz, mandioca, cacau e fumo e cortavam madeira. Os homens da cidade, que muita vez também tinham engenhos ou cultivos de campo, eram mercadores e traficantes fixados nas casas de comércio ou nos 
segmentos de inteligência mercantil. ${ }^{8}$ Embora muitos baianos tenham se embrenhando pelos grotões dos metais de Jacobina a Paranaguá, os negócios na capital continuaram firmes e fortes. A população, isso foi decorrência da corrida do ouro, estagnou nos 23, 24, 25 mil habitantes contados em 1724..$^{9}$ Mas a força dos que ficaram ou vieram se mostrou mais dominante, dominadora e determinante. Por 1755, eram 14 os homens de grande cabedal e 20, os de importante cabedal. ${ }^{10} 50,100$ anos antes, só gente dos Garcia d'Ávila e de uma e outra família detinham essa alcunha. Essa conjuntura tirava o sono de Antonio Gomes. Suas cartas ao pai deixam nítida a percepção da transição. Mas, contrárias às aparências, essa transição induzia mais ao sabido que a indefinido futuro. O que parecia estar em negociação era a afirmação do statu quo ante, mas sem a proeminência natural dos mesmos senhores.

O negócio do ouro havia muito vinha dando mostras de esgotamento. O negócio do açúcar havia muito vinha reganhando sua importância no imaginário dos brasílicos. No primeiro quarto dos setecentos, a euforia do ouro começou a perder paulatinamente sua força nos três lados do Atlântico. Brasis-Portugal-Africas. Os baianos foram incentivados a melhorar seu tabaco. O objetivo era quebrar o monopólio das colônias inglesas no mercado fino europeu. Vez que em Áfricas, o fumo do jeito que ia servia de escambo. O que era bom. Mas se queria conseguir ainda mais. No mesmo diapasão houve estímulos de aprimoramento de técnicas para o aproveitamento de cana. A instauração, em 1751, das mesas de inspeção nos principais portos da colônia e especialmente no da Bahia foi o cume dessa requalificação do fumo e do açúcar no mercado internacional. ${ }^{11}$ Mas quem estava fora do processo combativo de produção de açúcar e tabaco, como era o caso dos Ferrão Castelo Branco, atacava em outras frentes.

Reis do gado

Comprar e vender gado eram das atividades mercantis mais importantes dos Ferrão Castelo Branco. Na seguida, comprar e vender terras. Um não vinha sem o outro. Desde o

\footnotetext{
${ }^{8}$ José Antonio CALDAS - Notícia geral de toda esta Capitania da Bahia desde seu descobrimento até o presente ano de 1759. Salvador: Beneditina, 1951.

${ }^{9}$ Stuart SCHWARTZ - Segredos internos: Engenhos e escravos na sociedade colonial, 1550-1835. São Paulo: Companhia das Letras, 2000. p. 87.

${ }^{10}$ José Antonio CALDAS - Notícia geral, op. cit. (vide anexos).

${ }^{11}$ Stuart SCHWARTZ - Segredos internos, op. cit., pp. 337-42.
} 
advento das minas, o gado se tornou negócio de ouro para os baianos. Vivos, bois eram meios de transporte e de tração. Muito eficientes por sinal. Abatidos, eram formas de subsistência. Serviam de alimento e insumos para produção de derivados de couro e sebo. Eram comuns propriedades rurais com 2, 3 mil cabeças de gado. Sempre nos sertões. Quase sempre, afastadas das plantações de cana. Por 1710, a estimativa era de mais de um milhão desses víveres nas terras baianas e pernambucanas. Esses números foram multiplicados nos anos seguintes. O consumo preferencial de carne bovina foi se afirmando na Bahia. Muitos açougues foram estabelecidos na capital para suprir essa demanda crescente. ${ }^{12}$ Seria difícil estimar o tamanho das boiadas dos Ferrão Castelo Branco. Depois de tantas compras e vendas e perdas, muito do plantel de fins dos 1740s foram acrescidos ou o inverso. Mas esse negócio lhes retinha a atenção. Era dinheiro garantido. Rápido e custo baixo. Afora isso, auxiliava na manutenção de territórios. Geralmente, ao vender boiadas, arrendavam as terras. Com o dinheiro dos bois e do arrendo, compravam mais terras. Tudo isso feito desde a capital. Onde todos se encontravam.

Esse negócio envolvia riscos. Um e outro davam calote. Desapareciam da cidade e da capitania levando os bois. Antonio Gomes sofreu alguns. Não corriqueiros, nem muitos. O sistema de fiadores era bastante forte. E Antonio Gomes sabia bem utilizar. Quase nunca se vendia nada sem o avalista indicado pelo pai. Sempre se aconselhava com parente, desembargador ou clérigo, sobre a procedência do comprador. Muita vez também, a indicação do comprador vinha do pai ou dos parentes.

Apostar em gado e terras foi claramente a alternativa dos Ferrão Castelo Branco para se firmar naquele mundo em transformação. Iam os bois, ficavam as terras. Foi estratégia comum de quem acreditava na volta forte do açúcar. O açúcar continuou sempre produzido. Inclusive com lucro médio superior ao do ouro para os cofres de Portugal. Mas os baianos não percebiam assim. Nos anos de Antonio Gomes, essa mentalidade começou a mudar. Da economia de coleta complexa de prata e ouro as pessoas se moveram novamente para a de produção. Os Ferrão Castelo Branco estavam na expectativa. Contrária a qualquer sensação de fim do mundo, esperavam dias ainda melhores. Os ventos - com açúcar, fumo, arroz, gengibre, cacau, mandioca e gado - começaram mover mais assiduamente os moinhos da Bahia. Nada temiam. Apenas aguardavam.

\footnotetext{
${ }^{12}$ Milton SANTOS - O centro da cidade de Salvador. São Paulo: Edusp, 2008. pp. 41 ss. Stuart SCHWARTZ Segredos internos, op. cit., p. 88.
} 


\section{Capitais}

Em todo o gênero de ocupação falta sempre geralmente a probidade e boa economia, que não há no Brasil. Em tudo o mais pelo conseguinte reina sempre o ócio e tudo é mal governado.

Wenceslau Pereira da Silva Bahia, 1755.

\section{Changes in the colonial} governors in Brazil.

Edward Hay Lisboa, 1763.

Não há nesta capital quartéis para o regimento de artilharia (...) e ainda que sua Majestade a queira mandar fazer, nunca os soldados serão neles bem acomodados.

Conde da Cunha Rio de Janeiro, 1764

1763. Rio de Janeiro-Brasil, $1^{\circ}$ de janeiro. Silêncio de sepulcro começou a preencher as casas, os casebres e as mansões. Olhar nenhum conseguia disfarçar a contrição. Muitos, não continham a lágrima. A surpresa indesejada avançava produzindo assombro. Mesmo os mais discretos tiveram dificuldades em dissimular o espanto ao saber que o governador Gomes Freire de Andrade, o conde de Bobadela, vinha de morrer. Uma tragédia. Uma perda irreparável. Um estranho vazio que impunha certo obscurantismo severo que parecia vir do fundo dos tempos. Desde 1733, o nobre administrador português fazia parte do imaginário dos brasílicos do centro ao norte ao sul do domínio Brasil. Nas cortes dos principais reinos, era admirado, cortejado, reverenciado. Os que se bateram a favor ou contra ele, a favor ou contra suas causas, no Brasil e fora, agora, começavam a se sentir um pouco culpados. Quando não encarnaram uma espécie de orfandade. Em Lisboa, Rio de Janeiro, ilha de Santa Catarina, Vila de Santos, Rio Grande de São Pedro, e por outras partes do reino e das conquistas, a gente ficou habituada a ver nele um salvador. Fôra assim nos tempos do rei João. Continuava assim nos do rei José. Por tudo isso, os vassalos de todas as partes 
consentiam mal acreditar que o ilustre governador lhes havia abandonado para sempre. Somente 6, 7 dias depois, uma autoridade do Rio de Janeiro se encorajou a informar a tragédia à sua majestade o rei José em Portugal. O frade Antônio do Desterro, bispo da cidade, escreveu ao secretário do conselho ultramarino notificando a desgraça e suas razões: para ele e para todos, a capitulação em Sacramento. ${ }^{1}$ Ilha das Cobras-Rio de janeiro, 10 de janeiro. O escolhido responsável causador de toda desventura, preso e reprimido e açoitado e humilhado, também escreveu ao secretário do conselho da marinha contando sua versão e tentando se eximir das acusações. Vicente da Silva da Fonseca se dizia fiel a deus e ao soberano, mas temeroso da morte. Fugira, explicava, de ter tido seu sangue em mãos estrangeiras. Agora rogava em súplicas ao seu soberano o rei José em Lisboa para não ter seu sangue em mãos de iguais. ${ }^{2}$ Sabendo do teor desse agravo do comandante Vicente da Silva, o bispo contestou diretamente ao secretário Sebastião. Mas acrescentou, sem qualquer sutileza, a necessidade imperativa de sucessor imediato e imediatamente ao governo do Rio de Janeiro. $^{3}$

Enquanto essas notas atravessavam o Atlântico, a distensão na Europa estava em vias de se consolidar. Com dificuldades, conflitos, tensões.

Lisboa-Paris-Londres, 5-12 de janeiro. A feitura do tratado de paz beirou desandar. A França, conluiada com a Espanha, sugeriu impor trato de comércio especial de produtos agrícolas com Portugal. Isso sobreporia interesses da Inglaterra e desrespeitaria os interesses de Portugal. Martinho de Mello e Castro, enviado plenipotenciário português em Fontainebleau-Versailles, ameaçou abandonar as negociações caso fossem adicionadas essas cláusulas comerciais. O secretário Sebastião ficou irritadiço e irredutível. Despachou dura e fracamente com o embaixador inglês em Lisboa. Exigiu apoio incondicional de Londres em mostra da força de sua aliança. Edward Hay participou Londres. Martinho de Mello fez o mesmo. O duque de Bedford, negociador inglês, foi obrigado a entrar na discussão em favor de Portugal - e deles, ingleses, mesmos. O acordo estava havia dias no impasse. Com esse esforço, foram acertados os detalhes e, no dia 12, enviados para os reinos os instrumentos para ratificação do tratado. ${ }^{4}$ Londres, 18 de janeiro. O rei George mandou agradecer a cooperação do rei José no desfecho da guerra. No mesmo dia, o chanceler Egremont, por

\footnotetext{
${ }^{1}$ AHU - Rio de Janeiro, cx. 72, docs. 2, 1, 8 .

${ }^{2}$ AHU - Rio de Janeiro, cx. 72, doc. 4.

${ }^{3}$ AHU - Rio de Janeiro, cx. 72, doc. 8; cx. 70, doc. 79.

${ }^{4}$ E. Hay to Earl Egremont. Londres, 12 de janeiro de 1763. The National Archives - Londres, State Paper Foreing - Portugal, 89/58. Duke of Bedford to Earl Egremont. Paris, 12 de janeiro de 1763. The National Archives - Londres, State Paper Foreing - France, 78/256.
} 
demanda do parlamento e do próprio rei George, mandou o conde de Lippe iniciar o plano de retirada das tropas britânicas dos campos de atuação. Para auxiliá-lo, foi nomeado o conde de Loudoun, substituto do lord Tyrawly à frente das forças inglesas em Portugal. Salvaterra de Magos, 5 de fevereiro. O conde de Lippe mandou avisar o embaixador Hay e indagar o secretário Sebastião dos procedimentos para a retirada das forças. Em resposta, o secretário português e o embaixador inglês enviaram para Londres cópia integral do relatório de Lippe acrescida de documentos "relevantes" da administração lusa em tempos de guerra. ${ }^{5}$ Paris, 10 de fevereiro. França, Inglaterra, Portugal, Espanha e aliados assinaram tratado de paz. Londres, 22 de fevereiro. O chanceler Egremont solicitou ao embaixador Hay que cumprimentasse pessoalmente o secretário Sebastião por sua serenidade. Lisboa, 23 de fevereiro. Loudoun queixou para o chanceler Egremont certo ar evasivo nas decisões do secretário Sebastião referentes às tropas. ${ }^{6}$ Belém, 18 de março. O rei José e o secretário Sebastião convocaram o embaixador Hay para conversa reservada. Queriam agradecer o empenho dos ingleses na manutenção da integridade do reino. Deixaram em mãos cartas de agradecimento endereçadas ao rei George e ao duque de Bedford. No mesmo dia, chegara a notícia de que Madrid ordenara a retiradas das tropas espanholas de solo português. Horas depois, o secretário Sebastião chamou Loudoun para negociar a retirada das tropas inglesas. No mês de abril, representantes de reinos outrora ingratos começaram a chegar. Diplomatas espanhóis foram pouco a pouco se instalando na corte do rei José. Traziam, em vão, cumprimentos do rei Carlos. Ninguém queria aceitar. A mágoa continuava grande. Muitas das armas do exército português capturadas pelo espanhol ainda não tinham sido devolvidas. Como muitas das armas dos espanhóis estavam em posse dos ingleses que lutaram em Havana. A imposição do secretário Sebastião para os homens do rei George era que não devolvessem as armas de Havana antes de serem entregues as de Portugal. O embaixador Martinho de Mello, que viera de Paris a Lisboa antes de retornar a Londres, foi orientado a forçar os ingleses a, mais decididamente, interceder. O secretário Sebastião estava disposto a manter e ampliar a aliança anglo-portuguesa. Mas reivindicava mais igualdade. Os parlamentares ingleses queriam mais informações sobre as condições concretas para essa

\footnotetext{
${ }^{5}$ Earl of Egremont to E. Hay. Londres, 18 de janeiro de 1763. The National Archives - Londres, State Paper Foreing - Portugal, 89/58. Earl of Egremont to Count Schaumburg-Lippe. Londres, 18 de janeiro de 1763. The National Archives - Londres, State Paper Foreing - Portugal, 89/58. Count Schaumburg-Lippe to E. Hay. Salvaterra de Magos, 5 de fevereiro de 1763. The National Archives - Londres, State Paper Foreing - Portugal, $89 / 58$.

${ }^{6}$ Earl of Egremont to E. Hay. Londres, 22 de fevereiro de 1763. The National Archives - Londres, State Paper Foreing - Portugal, 89/58. Earl of Loudoun to Earl of Egremont. Lisboa, 23 de fevereiro de 1763. The National Archives - Londres, State Paper Foreing - Portugal, 89/58. Earl of Loudoun to Earl of Egremont. Lisboa, 7 de março de 1763. The National Archives - Londres, State Paper Foreing - Portugal, 89/58.
} 
empresa. O embaixador Hay foi lacônico. Duvidava que "the Portuguese have suficiente capital". Os homens de Londres orquestraram silêncio. A não-resposta indicava que as guerras, doravante, seriam em tom particular. Cada qual com seus problemas. O secretário Sebastião estava se convencendo disso. E, ao mesmo tempo, amargando a desilusão de não saber ao certo o que fazer sem Bobadela. ${ }^{7}$

A notícia da morte de Bobadela chegou a Lisboa por esses dias. Por onde passava, desolava. O vazio imenso que o governador deixou fez a corte inteira repensar a importância que ele tinha para ela. No momento que ocorrera, o incidente impôs a todos reconhecer que, em verdade, uma página da história do reino e da colônia vinha de ser tornada. Na fluidez dos dias e dos fatos, se fazia difícil reter alguma lição. Mas o secretário Sebastião sabia da urgência de se firmar uma decisão.

Vinte e poucos dias depois da morte do governador, os oficiais da câmara do Rio de Janeiro informaram ao rei José da constituição do governo interino. Fizeram como se fizera na Bahia quando da morte do conde de Lavradio. Mas sem as complicações de lá. Apanharam o superior da igreja, da relação e do exército. O bispo, o chanceler e o brigadeiro. Frei Antonio do Desterro, desembargador João Alberto de Castelo Branco e o militar José Fernandes Pinto Alpoim. Pelo dia 22 de janeiro já estavam empossados e dando ordens. ${ }^{8}$ Antes disso, no dia 15 de janeiro, o bispo começou a solicitar novo governador. Não por suposta e real impotência do governo interino em governar. Mas pela incapacidade de se substituir Bobadela. A pressão sobre qualquer não-governador de fato e direito e de grandeza seria insuportável. A complexidade dos interesses convergidos no Rio de Janeiro tornava inviável ser governador sendo outra coisa. Bispo, chanceler, brigadeiro, por exemplo. Cada uma dessas funções colaborava para fazer inferno o cotidiano de seus titulares. ${ }^{9}$ Fora isso, mesmo um substituto a Bobadela teria dificuldade em harmonizar as demandas. Era Sacramento, era o ouro das minas, eram os escravos de Angola, eram os navios inimigos pelas costas, eram os conflitos internos. Não seria fácil ser governador. Pior ainda na sucessão de Bobadela. As lamúrias do bispo, por certo, sensibilizaram os homens do rei José em Lisboa. Era notório

\footnotetext{
${ }^{7}$ E. Hay to Earl of Egremont. Lisboa, 18 de março de 1763. The National Archives - Londres, State Paper Foreing - Portugal, 89/58. E. Hay to Earl of Egremont. Lisboa, 18 de março de 1763. The National Archives Londres, State Paper Foreing - Portugal, 89/58. E. Hay to Earl of Egremont. Lisboa, 2 de abril de 1763. The National Archives - Londres, State Paper Foreing - Portugal, 89/58.

${ }^{8}$ AHU - Rio de Janeiro, cx. 72, doc. 17.

${ }^{9}$ AHU - Rio de Janeiro, cx. 72, doc. 4.
} 
para todos o bate-cabeça na Bahia. A importância da Bahia e de sua área de influência estavam absolutamente desconsideras sem governador. Tudo era mal governado na visão e nos tempos do intendente Wenceslau Pereira da Silva na Bahia, quando se aguardava, sem ninguém no posto, a chegada o conde dos Arcos. ${ }^{10} \mathrm{E}$ continuou sendo desde que o governo interino sucedeu o falecido conde de Lavradio. A decisão de Lisboa, em termos proporcionais, foi astuta e veloz. O rei José nomeou o novo governador como vice-rei. Essa determinação foi simbólica e litúrgica e sensata e operacional. Verdadeira grande aposta. Somente o simbolismo e a liturgia de um vice-rei poderia se impor diante da grandeza da memória da presença de Bobadela.

Ser vice-rei envolvia cuidar de assuntos fiscais, econômicos, de segurança, defesa costeira, colonato, da presidência da relação e dos assuntos seculares da igreja. Suprir essas demandas exigia experiência militar e no ultramar. ${ }^{11} \mathrm{O}$ conde da Cunha preenchia as prerrogativas. Nascera em 1700. Tinha, portanto, mais de sessenta anos. Vinha da linhagem dos Tábua. Casou-se com a condessa de Vale dos Reis - mulher duma das famílias mais influentes na corte desde os tempos de Felipe II quando o vice-rei de Portugal, no contexto de união ibérica, iniciou a linhagem dos Vale dos Reis. O berço e o casamento do distinto conde, agora governador vice-rei, definiram sua trajetória e seu destino. Acumulou diversas funções. Foi trinchante-mor da casa real. Comendador de Almendra e Idanha-a-Nova. Deputado em juntas de estado. Mestre de campo, general de guerra. Governador e capitão-mor em Mazagão, importante possessão portuguesa no norte da África, Marrocos, de 1745 a 1752. Governador de Angola de 1753 a 1758. De volta ao reino, foi conselheiro de guerra e chefe de artilharia. ${ }^{12}$ Esteve entre os secretários do rei José nos momentos decisivos da guerra dos sete anos. Ajudou a administrar a crise com os franceses que o incidente de Lagos provocou. Trabalhou hand by hand com o enviado inglês portador das desculpas ao reis de França e Portugal por aquela derrapagem militar. Despachou e se entrevistou com o enviado francês

\footnotetext{
${ }^{10}$ BNRJ - AMU - Bahia, 2018.

11 A. J. R. RUSSEL-WOOD - Governantes e agentes. In.: Francisco BETHENCOURT \& Kirti CHAUDHURI História da expansão portuguesa. 3. O Brasil na balança do império. Lisboa: Círculo de leitores, 1998. pp. 177 Ss.

${ }^{12}$ Izabela Gomes GONÇALVES - A sombra e a penumbra: o vice-reinado do conde da Cunha e as relações entre centro e periferia no Império português (1763-1767). Niterói, 2010. (Dissertação apresentada ao departamento de História da Universidade Federal Fluminense), pp. 60 ss. Nuno Gonçalo MONTEIRO Trajetórias sociais e governo das conquistas. Notas preliminares sobre os vice-reis e governadores-gerais do Brasil e da Índia nos séculos XVII e XVIII. In.: João FRAGOSO; Maria Fernanda BICALHO; Maria de Fátima GOUVÊA - O antigo regime nos trópicos: a dinâmica imperial portuguesa (séculos XVI-XVIII). Rio de Janeiro: Civilização brasileira, 2001. pp. 266-7.
} 
quando foi indicado para substituir o embaixador luso em Paris. Esteve próximo do embaixador Hay em Lisboa. Permaneceu junto ao secretário Sebastião durante a noite sem fim, da entrada da Espanha em guerra e da seguinte iminência de o reino ser invadido e dominado. Acompanhou de perto as incursões de seu irmão, o secretário do exterior do rei José. Foi dos entusiasmados com os avanços de Martinho de Mello em Paris. Foi dos incrédulos da morte de Bobadela no Rio de Janeiro. Surpresa maior - carregada de honra - foi ter sido escolhido para substituí-lo.

Solucionada em tese a situação do Rio de Janeiro, mas não de fato as do reino e do Brasil. As reclamações de todas as partes contra todas as partes só fizeram se multiplicar depois do 10 de fevereiro. Os diplomatas, verdadeiros agentes pacificadores em tempos de paz, passaram a ter excessivo trabalho. Os homens do rei Carlos visitavam diariamente um e outro secretário do rei José em Lisboa com um e outro protesto. O embaixador Hay recorrentemente entregava queixas dos ingleses ao tratamento recebido em terras portuguesas. O secretário Sebastião respondia constantemente aludindo à aliança anglo-lusa e à necessidade de se repelir os espanhóis dos negócios do reino. Sacramento era um dos negócios em questão. Ainda em janeiro, os governadores interinos do Rio de Janeiro informavam o secretário da marinha em Lisboa e mandavam agradecer aos ingleses pelo envio "dos esforços de socorros para a defesa da nova colônia do Sacramento". Contavam que as duas naus de guerra do capitão Macnamara haviam bem aportado na cidade. ${ }^{13}$ Entretanto, era preciso cautela na travessia do oceano sentido Brasil. Toda a costa estava infestada de navios de bandeira francesa repletos de gente nada amistosa. ${ }^{14}$ Nesse ambiente, foi que Martinho de Mello, em trânsito entre Paris e Lisboa, escreveu ao chanceler Egremont reconsideração da execução do tratado de paz. Como os franceses estavam zanzando pelas costas do Brasil aterrorizando as gentes e os espanhóis haviam anexado Sacramento e não queriam devolver, que os britânicos rescindissem as ordens de restituição de Havana. ${ }^{15}$

O secretário Sebastião tinha sugerido essa manifestação de Martinho de Mello e reforçou em duras conversas com o embaixador Hay. Que seguida de poucas palavras. Como toda a gente de Londres. Era sentido em Lisboa que o reino ainda corria riscos. Os homens do

\footnotetext{
${ }^{13}$ AHU - Rio de Janeiro, cx. 72, doc. 15A; cx 75, doc. 81.

${ }^{14}$ AHU - Rio de Janeiro, cx. 72, doc. 16A; cx 75, doc. 80; cx 70, doc. 79.

${ }^{15}$ Martinho de Mello e Castro to Earl of Egremont. Figuera, 29 de abril de 1763. The National Archives Londres, State Paper Foreing - France, 78/256.
} 
rei José sabiam que a melhor maneira de avançar para tranquilidade era pelo reforço da aliança com a Inglaterra. De tanto forçar, o rei George e o parlamento inglês vigoraram sua contribuição. No dia 20 de maio, o chanceler Egremont enviou ao embaixador Bedford em Paris duplicatas de ordens de sua majestade britânica para restituição de Manila e das Filipinas aos espanhóis. Essas duplicatas deveriam ser entregues a Girolamo Grimaldi, enviado do rei Carlos em Versailles. Em contraponto, a Grimaldi ficava a incumbência de convencer os homens del Prado a restituir aos concernentes territórios agregados em tempos de guerra. ${ }^{16}$ Resolveria em nada a pressão. Mas com isso, pouco a pouco, a Inglaterra ia se desvencilhando dos negócios de Portugal. Embora Portugal seguisse fortemente dependente dela e ela, a vencedora da guerra dos sete anos, seguisse interessada nas coisas de Portugal e do Brasil.

No dia 9 de maio, o embaixador Hay informou a Londres da morte de Bobadela e de toda comoção que ela vinha causando. No dia 23, informou da decisão do rei José de mandar o substituto como vice-rei. Foi totalmente frio. Escreveu "changes in the colonial governors in Brazil”. Nada especialmente relevante a mais. ${ }^{17} \mathrm{O}$ Brasil parecia estar distante. Infinitamente mais distante que antes. O que interessava, como sempre interessara, eram os cargo-lists dos navios chegados de lá. O enviado inglês em Lisboa noticiava com entusiasmo, referente ao Brasil, apenas a quantidade de açúcar, de rolos de tabaco, de barris de arroz, de cruzados em prata e ouro que vinham vindo do Portugal americano. ${ }^{18}$

Os sucederes do fim da guerra, como as barcas do Brasil, também interessava aos ingleses. Em poucos meses, os homens do rei José promoveram "drastic reform of the Portuguese army". Com o auxílio de Lippe e Loudoun, a retirada das tropas foi efetuada. Muitos recrutados forçadamente foram devolvidos às suas famílias. Diversos presos de guerra foram entregues à liberdade. Os mercenários suíços foram devidamente punidos. E novo plano militar foi instaurado. Promessa de vencimentos, de carreira, de decência. Isso seria

\footnotetext{
${ }^{16}$ Earl of Egremont to Duke of Bedford. Whitehall, 20 de maio de 1763. The National Archives - Londres, State Paper Foreing - France, 78/257.

${ }^{17}$ E. Hay to Earl of Egrement. Lisboa, 9 de maio de 1763. The National Archives - Londres, State Paper Foreing - Portugal, 89/58. E. Hay to Earl of Egrement. Lisboa, 23 de maio de 1763. The National Archives - Londres, State Paper Foreing - Portugal, 89/58 - fólio 136.

${ }^{18}$ E. Hay to Earl of Egrement. Lisboa, 22 de agosto de 1763. The National Archives - Londres, State Paper Foreing - Portugal, 89/58.
} 
essencial para o reino luso. Especialmente para suas conquistas. Decididamente para o Brasil. Cinco meses da paz de Paris tinham se passado e Sacramento continuava embargada. ${ }^{19}$

No dia 16 de setembro, o conde da Cunha chegou ao Rio de Janeiro. Foram 57 dias de viagem desde Lisboa. Os governadores foram apanhá-lo. Havia mais de mês se sabia que ele viria. Homens bons e gente do povo estavam em alerta e sobreaviso. No dia 19 foram ajudar a lotar as salas da câmara e no dia 29, da relação, cheios de poejo e boas-vindas, para prestigiar a posse do novo governador. Houve festas. Moradores estiveram muito entusiasmados. ${ }^{20}$ Contentes. Esperançosos. Muitos, mesmo com alguma idade, jamais tinham participado duma cerimônia coletiva similar. A notícia da assinatura da paz de Paris tinha dado refrigério a muitos corações. Desde julho, era assunto na cidade. Acreditavam ser o lance importante para o fim das injúrias. $\mathrm{O}$ adeus ao fantasma inversor de bandeira inimiga. A perda das praças do sul promoveu desgosto e prejuízos insofismáveis. O mais duro foi o desaparecimento do governador salvador. A chegada do conde da Cunha selava a possibilidade concreta de dias melhores. Ao menos, menos carregados de medo. O governador apreendeu de imediato essa expectativa da gente. De suas primeiras determinações foi enviar o brigadeiro José Fernandes Pinto de Alpoim para Buenos Aires para negociar com o Pedro Cevallos. ${ }^{21}$ Em seguida, passou a estudar e avaliar de corpo presente a situação e as condições do Rio de Janeiro. Isso já era outubro entrado. Por meados de dezembro, saiu seu relatório dando conta do que viu, sentiu e ouviu.

O Rio de Janeiro era um lugar lastimoso. Uma cidade febril. Infestada de varíola e lepra. Quase tudo era precário. Dos prédios e ruas aos portos e praças. Os soldados eram moles. Mal fardados, mal alimentados. Sem uniformidade. Com soldos atrasados. Inclusive os daqueles que faziam a segurança pessoal dos homens do rei na cidade. Nenhuma condição mais favorável para desvios de conduta e corrupção. Os cofres da fazenda real e os armazéns estavam em ocos. As fortalezas, sem fortes. As tropas, sem armas. Sabe-se lá o que deve ter imaginado o secretário do ultramar, quem recebera esse relatório. ${ }^{22}$

\footnotetext{
${ }^{19}$ E. Hay to Earl of Egrement. Lisboa, 22 de julho de 1763. The National Archives - Londres, State Paper Foreing - Portugal, 89/58.

${ }^{20}$ AHU - Rio de Janeiro, cx. 76, doc. 41.

${ }^{21}$ AHU - Rio de Janeiro, cx. 76, doc. 11.

${ }^{22}$ AHU - Rio de Janeiro, cx. 73, docs. 39, 40.
} 
Até o fim de seus dias no governo, o conde não fez que reclamar melhoramentos. Tudo faltava para a cidade do Rio de Janeiro ser capital. Inclusive, e mais importante, a própria noção de capital.

Enquanto isso, a Bahia seguia sem governador. Os interinos seguiam batendo cabeça. As notícias do sul eram sempre as piores. Pedro Cevallos estava duro na queda. Os esforços dos homens do rei George foram vertidos para a extremidade norte das Américas. Ninguém por lá queria saber de pagar tributos de guerra. A gente de Versailles passou a amargar a concretude do declínio. A afirmação mundial dos ingleses ia estragando o petit-déjeuner diário dos homens do rei Louis. O conde da Cunha continuava veiando por sua capitania. Reclamando constantemente em função da sua real condição de não-capital. O secretário Sebastião continuou com a cabeça nas capitais - Paris, Londres, Madrid - e com a esperança de do Brasil jamais cessar de vir capitais - commodities tipo ouro, açúcar, fumo. 
Epílogo 


\section{A ubiquidade do memento more}

Cualquier destino, por largo $\mathrm{y}$ complicado que sea, consta en realidad de un solo momento: el momento en que el hombre sabe para siempre quién es.

Jorge Luis Borges, Biografía de Tadeo Isidoro Cruz (1829-1874)

Mis arreos son las armas, mi descanso el pelear.

Miguel de Cervantes, Don Quijote de la Mancha, (I, 2).

Dio me la dona, guai a chi la tocca.

Napoleão Bonaparte

A onipresença do desassossego corroeu os sentidos do reinado do rei José e da gestão do secretário Sebastião. Impertinentes ventos boreais os faziam lembrar permanentemente dos perigos de reinar e das desilusões do administrar. Suas obrigações lhes impunham dias rudes. Jamais foi, nem jamais será, fácil tomar decisão. De fato reinar e governar jamais perderá essa sua dimensão forçosamente deliberativa. Decisão: il faut la prendre. A arte de bem fazê-lo em tempos de guerra e em tempos de paz continuará, por certo, sendo imperioso enigma. Algo meio mágico que parece vir do fundo dos anos. Escolher o certo no momento oportuno não ficou para quaisquer. Nos 12,13, 14 primeiros anos do rei José e do secretario Sebastião à frente de Portugal o que se viu foram homens fortes. Gente que não comenta cenário. Efetivamente os modifica. Essa gente misteriosa envolta na mística de decidir marcou profundamente a história de seu tempo e de sua geração. O destino do Brasil, embora não fosse tão claro, já estava mais ou menos selado. A escolha de Angola, desde os tempos dos Sá, havia comprometido para todo o sempre o que éramos e o que viríamos a ser. Nem o ouro 
nem a prata nem os diamantes mudariam esse devir. Os pés e os braços negros imporiam uma complexidade inimaginável à sociedade que os portugueses na América viam se construir. Quando o rei José e o secretário Sebastião chegaram em cena não havia mais muito que fazer. O infame imundo comércio tinha se imposto como o ethos do tempo e o sentido da civilização. O pecado hiperdescomunal tinha se firmado inexpugnável. No entanto, sob as palmeiras, nada é tão comportado que agregue apenas um pecado. Fosse nas Américas, fosse nas pátrias-mães, o povo, em geral, acreditava profundamente em Deus. O medo do juízo final fazia de todos penitentes. Crentes. Consequentes. Ninguém admitia imaginar acordar no além fora do mundo melhor. Tudo faziam para estar no suprassumo de seus ânimos para quando Ele desse de voltar. Amar o rei, homem d'Ele na terra, era o bom primeiro começo. $\mathrm{O}$ mundo era, certo, já imperfeito. Isso ao menos desde a maldita maçã. Os reis traíam. Os padres fornicavam. Os fiéis se desviavam. Alguns até ao cúmulo de atentar contra a existência do ungido que era o rei. Mas a retórica da salvação ainda conseguia amarrar um sistema e um regime. Ambos mutuamente consequentes. O antigo regime, que imiscuía gente que acreditava muito em Deus com aqueles que gostavam acima de tudo de dinheiro, conseguiu fazer muito da gente de mesmo sangue europeu peregrinando em terras distantes e desconhecidas reconhecer em seu rei o próprio salvador. Essa devoção, somada a outras variantes, dificultaria definitivamente o menosprezo de onde tudo começou: Portugal. Nesse quesito, o rei José estava ainda um pouco garantido. Com poder e aura intransferíveis, sua gente, mesmo os degredados e desgraçados além-mar, tinha quase que como mal debandar. Essa fidelidade semicelestial garantiu, e continuaria garantindo, certa autoridade intransferível ao monarca.

A força e a autonomia do vil negócio de mercadejar gentes para o mundo agrário americano e de enviar produtos semimanufaturados - fumo, cachaça, chocolate - para o mundo tribal africano não quebraria o encanto que a referência real representava e impunha. O calor da bilateralidade existencial soldada ao sul em cinta no Atlântico não apagava a chama solitária viva ao norte onde residia em pessoa sua majestade o rei. Do Rio de Janeiro, da Bahia, de Luanda, de Goa, de Macau, os tinos singravam irresistivelmente para Belém, para Lisboa, para Portugal. A externalidade da devoção nos domínios era um fato violentamente incontestável. Nada sinalizou melhor isso que a solidariedade pós-sismo de Lisboa de 1755 para reconstruir a casa e a cidade-morada do rei e de seus próximos. Gentes de todas as praças do império se empenharam dia e noite e dia para mandar dinheiro e desejo de vida longa ao soberano. Quando cretinos tentaram exterminar o rei José em 1758, muita gente se pôs perplexa e em vigília mandando boas intenções para sacar seu senhor da 
inominável agonia da morte. Muitos que, por viver em colônia, perderam, gostariam de estar na praça do cais de Belém, no 13 de janeiro de 1759, para saborear com espírito e olhos o sangue dos tidos canalhas lavar as lâminas e cordas da justiça real. A reciprocidade dessa devoção era paga no simples detalhe de o rei ser rei.

Mesmo em se sendo rei, a vida era real. Contingente. Nada de celestial. O atentado imperfeito de 1758 deu bem a mostra disso. Coube massivamente ao secretário Sebastião manejar as aporias da concretude dessa danação do cotidiano. O governador Bobadela foi um braço forte do secretário nessa empreitada além-mar, nas Américas, no Brasil. Muito mais que se poderia supor. Sendo o Brasil importante empório de Portugal e estando Portugal em seus dias infernais com seus inimigos europeus pelos idos dos 1750s, quanto mais autonomia e autodeterminação o nobre governador aplicasse em seu ofício, muito que melhor para o secretário Sebastião que tentava garantir a salubridade dos dias do rei em seu reino. A insanidade dos outros na guerra poderia fazer tudo de e em Portugal se perder.

O que venho aqui tentando dizer é que o núcleo geral de peregrinação e de absoluta preocupação do mundo português era, e continuaria sendo, Belém-Lisboa-Portugal. Era Belém-Lisboa, antes e acima de tudo, a genuína capital. Isso pode beirar o truísmo, mas, reforçado, pode pôr em reexame tudo que se argumentou ao longo deste estudo.

A questão fundamental dessa fixação natural de Belém-Lisboa como centro, central, capital sugere indagar se fora de Portugal o império português tinha capitais. Não se trata de mero jogo de escalas, tampouco de palavras. A casa do vice-rei, fosse onde fosse, configurava capital? Ainda não parece suficientemente convincente. A centralidade do rei em seu palácio ao certo não admitia concorrência. Redizendo de modo direto: existiam de fato capitais nas colônias? Existia de fato capital no Brasil da colônia quando este não era bem ele ainda?

Em tudo que escrevi até aqui, supus que sim. A partir daqui, fica a dúvida. 
Fontes e referências bibliográficas 


\section{Arquivo Histórico Ultramarino}

(Projeto Resgate e Acervo da Biblioteca Nacional do Rio de Janeiro)

AHU - Rio de Janeiro, cx. 70, docs. 28, 29, 40 e 65; Brasil Limites, cx. 2, doc. 125.

AHU - Rio de Janeiro, cx. 72, doc. 15A; cx 75, doc. 81.

AHU - Rio de Janeiro, cx. 72, doc. 16A; cx 75, doc. 80; cx 70, doc. 79.

AHU - Rio de Janeiro, cx. 72, doc. 17.

AHU - Rio de Janeiro, cx. 72, doc. 22.

AHU - Rio de Janeiro, cx. 72, doc. 4.

AHU - Rio de Janeiro, cx. 72, doc. 8; cx. 70, doc. 79.

AHU - Rio de Janeiro, cx. 72, docs. 2, 1, 8.

AHU - Rio de Janeiro, cx. 73, docs. 39, 40.

AHU - Rio de Janeiro, cx. 76, doc. 11.

AHU - Rio de Janeiro, cx. 76, doc. 41.

AHU - Rio de Janeiro, documentos avulsos, cx. 125, doc. 22.

BNRJ - AMU - Bahia, 1951.

BNRJ - AMU - Bahia, 2018.

BNRJ - AMU - Bahia, 2077.

BNRJ - AMU - Bahia, 2079.

BNRJ - AMU - Bahia, 2297.

BNRJ - AMU - Bahia, 5033.

BNRJ - AMU - Bahia, 5041.

BNRJ - AMU - Bahia, 5083.

BNRJ - AMU - Bahia, 5322.

BNRJ - AMU - Bahia, 5332.

BNRJ - AMU - Bahia, 5629.

BNRJ - AMU - Bahia, 5636.

BNRJ - AMU - Bahia, 5765.

BNRJ - AMU - Bahia, 5766.

BNRJ - AMU - Bahia, 5767.

BNRJ - AMU - Bahia, 5827.

BNRJ - AMU - Bahia, 5828.

BNRJ - AMU - Bahia, 6000.

BNRJ - AMU - Bahia, 6001. 
BNRJ - AMU - Bahia, 6009.

BNRJ - AMU - Bahia, 6039.

BNRJ - AMU - Rio de Janeiro, 6039.

\section{The National Archives - Londres}

A. Castres to A. Amyand. Lisboa, 12 de novembro de 1753. The National Archives Londres, State Paper Foreing - Portugal, 89/48.

A. Castres to C. Amyand. Lisboa, 23 de fevereiro de 1754. The National Archives - Londres, State Paper Foreing - Portugal, 89/48.

A. Castres to Duke of Bedford. Lisboa, 17 de abril de 1751. The National Archives - Londres, State Paper Foreing - Portugal, 89/48.

A. Castres to Earl of Holdernesse. Londres, 3 de julho de 1751. The National Archives Londres, State Paper Foreing - Portugal, 89/48.

A. Castres to R. N. Aldworth. Lisboa, 8 de dezembro de 1750. The National Archives Londres, State Paper Foreing - Portugal, 89/47.

Comentário avulso e secreto. Paris, 22 de setembro de 1761. The National Archives Londres, State Paper Foreing - State Paper Foreing - France, 78/252.

Count Schaumburg-Lippe to E. Hay. Salvaterra de Magos, 5 de fevereiro de 1763. The National Archives - Londres, State Paper Foreing - Portugal, 89/58.

Duke of Bedford to Earl Egremont. Paris, 12 de janeiro de 1763. The National Archives Londres, State Paper Foreing - France, 78/256.

E. Hay to Earl Egremont. Londres, 12 de janeiro de 1763. The National Archives - Londres, State Paper Foreing - Portugal, 89/58.

E. Hay to Earl of Egrement. Lisboa, 22 de agosto de 1763. The National Archives - Londres, State Paper Foreing - Portugal, 89/58.

E. Hay to Earl of Egrement. Lisboa, 23 de dezembro de 1761. The National Archives Londres, State Paper Foreing - Portugal, 89/54.

E. Hay to Earl of Egrement. Lisboa, 23 de maio de 1763. The National Archives - Londres, State Paper Foreing - Portugal, 89/58 - fólio 136.

E. Hay to Earl of Egrement. Lisboa, 29 de abril de 1763. The National Archives - Londres, State Paper Foreing - Portugal, 89/58. 
E. Hay to Earl of Egrement. Lisboa, 9 de dezembro de 1761. The National Archives Londres, State Paper Foreing - Portugal, 89/54.

E. Hay to Earl of Egremont. Lisboa, 12 de março de 1762. The National Archives - Londres, State Paper Foreing - Portugal, 89/55.

E. Hay to Earl of Egremont. Lisboa, 14 de outubro de 1762. The National Archives - Londres, State Paper Foreing - Portugal, 89/57.

E. Hay to Earl of Egremont. Lisboa, 15 de outubro de 1762. The National Archives - Londres, State Paper Foreing - Portugal, 89/57.

E. Hay to Earl of Egremont. Lisboa, 17 de janeiro de 1762. The National Archives - Londres, State Paper Foreing - Portugal, 89/55.

E. Hay to Earl of Egremont. Lisboa, 18 de março de 1763. The National Archives - Londres, State Paper Foreing - Portugal, 89/58.

E. Hay to Earl of Egremont. Lisboa, 2 de abril de 1763. The National Archives - Londres, State Paper Foreing - Portugal, 89/58.

E. Hay to Earl of Egremont. Lisboa, 22 de março de 1762. The National Archives - Londres, State Paper Foreing - Portugal, 89/55.

E. Hay to Earl of Egremont. Lisboa, 23 de dezembro de 1761. The National Archives Londres, State Paper Foreing - Portugal, 89/54.

E. Hay to Earl of Egremont. Lisboa, 27 de abril de 1762. The National Archives - Londres, State Paper Foreing - Portugal, 89/55, folio 280.

E. Hay to Earl of Egremont. Lisboa, 8 de novembro de 1762. The National Archives Londres, State Paper Foreing - Portugal, 89/57.

E. Hay to Earl of Egremont. Lisboa, 9 de novembro de 1762. The National Archives Londres, State Paper Foreing - Portugal, 89/57.

E. Hay to R. Wood. Lisboa, 6 de maio de 1759. The National Archives - Londres, State Paper Foreing - Portugal, 89/51, folio 153.

E. Hay to W. Pitt. Lisboa, 19 de maio de 1759. The National Archives - Londres, State Paper Foreing - Portugal, 89/51.

E. Hay to W. Pitt. Lisboa, 28 de março de 1761. The National Archives - Londres, State Paper Foreing - Portugal, 89/54.

E. Hay to W. Pitt. Lisboa, 19 de maio de 1759. The National Archives - Londres, State Paper Foreing - Portugal, 89/51.

E. Hay to W. Pitt. Lisboa, 9 de dezembro de 1757. The National Archives - Londres, State Paper Foreing - Portugal, 89/51. 
Earl of Egrement to E. Hay. Londres, 21 de novembro de 1761. The National Archives Londres, State Paper Foreing - Portugal, 89/54.

Earl of Egremont to Count Schaumburg-Lippe. Londres, 18 de janeiro de 1763. The National Archives - Londres, State Paper Foreing - Portugal, 89/58.

Earl of Egremont to Duke of Bedford. Whitehall, 20 de maio de 1763. The National Archives - Londres, State Paper Foreing - France, 78/257.

Earl of Egremont to E. Hay. Londres, 13 de abril de 1762. The National Archives - Londres, State Paper Foreing - Portugal, 89/55, folios 174-200.

Earl of Egremont to E. Hay. Londres, 18 de janeiro de 1763. The National Archives Londres, State Paper Foreing - Portugal, 89/58.

Earl of Egremont to E. Hay. Londres, 18 de maio de 1762. The National Archives - Londres, State Paper Foreing - Portugal, 89/56.

Earl of Egremont to E. Hay. Londres, 22 de fevereiro de 1763. The National Archives Londres, State Paper Foreing - Portugal, 89/58.

Earl of Egremont to E. Hay. Londres, 7 de setembro 1762. The National Archives - Londres, State Paper Foreing - Portugal, 89/57.

Earl of Egremont to Lord Tyrawly. Londres, 15 de junho de 1762. The National Archives Londres, State Paper Foreing - Portugal, 89/56, folio 19.

Earl of Egremont to Martinho de Mello e Castro. Londres, 13 de abril de 1762. The National Archives - Londres, State Paper Foreing - Portugal, 89/55.

Earl of Kinnoull to W. Pitt. Lisboa, 10 de março de 1760. The National Archives - Londres, State Paper Foreing - Portugal, 89/52.

Earl of Kinnoull to W. Pitt. Lisboa, 11 de outubro de 1760. The National Archives - Londres, State Paper Foreing - Portugal, 89/53 - folio 105.

Earl of Kinnoull to W. Pitt. Lisboa, 14 de abril de 1760. The National Archives - Londres, State Paper Foreing - Portugal, 89/52.

Earl of Kinnoull to W. Pitt. Lisboa, 16 de abril de 1760. The National Archives - Londres, State Paper Foreing - Portugal, 89/52 - folios 73-8 e 81-87.

Earl of Kinnoull to W. Pitt. Lisboa, 21 de junho de 1760. The National Archives - Londres, State Paper Foreing - Portugal, 89/52 - folio 108.

Earl of Kinnoull to W. Pitt. Lisboa, 7 de junho de 1760. The National Archives - Londres, State Paper Foreing - Portugal, 89/52.

Earl of Loudoun to Earl of Egremont. Lisboa, 23 de fevereiro de 1763. The National Archives - Londres, State Paper Foreing - Portugal, 89/58. 
Earl of Loudoun to Earl of Egremont. Lisboa, 7 de março de 1763. The National Archives Londres, State Paper Foreing - Portugal, 89/58.

G. Crowle to C. Amyand. Lisboa, 24 de fevereiro de 1754. The National Archives - Londres, State Paper Foreing - Portugal, 89/49.

G. Grimaldi to Earl of Egrement. Paris, 28 de maio de 1763. The National Archives Londres, State Paper Foreing - France, 78/257 - folio 90.

Instructions from the King to the Duke of Bedford. St. James, 4 de setembro de 1762. The National Archives - Londres, State Paper Foreing - France, 78/253, folio 7.

List of British subjects killed by the earthquake at Lisbon Nov. 1, 1755. The National Archives - Londres, State Paper Foreing - Portugal, 89/50.

Lord Holdernesse to G. Growle. Londres, 26 de junho de 1753. The National Archives Londres, State Paper Foreing - Portugal, 89/49.

Lord Tyrawly to Earl of Egremont. Lisboa, 12 de março de 1762. The National Archives Londres, State Paper Foreing - Portugal, 89/55.

Lord Tyrawly to Earl of Egremont. Lisboa, 22 de março de 1762. The National Archives Londres, State Paper Foreing - Portugal, 89/55.

Lord Tyrawly to Earl of Egremont. Lisboa, 22 de março de 1762. The National Archives Londres, State Paper Foreing - Portugal, 89/55, folio 82.

Lord Tyrawly to Earl of Egremont. Lisboa, 26 de junho de 1762. The National Archives Londres, State Paper Foreing - Portugal, 89/56.

Lord Tyrawly to Earl of Egremont. Lisboa, 29 de maio de 1762. The National Archives Londres, State Paper Foreing - Portugal, 89/56.

M. Hiccox to H. Fox. Madeira-Portugal, 14 de setembro de 1756. The National Archives Londres, State Paper Foreing - Portugal, 89/50.

Martinho de Mello e Castro to Earl of Egrement. Paris, 29 de abril de 1763. The National Archives - Londres, State Paper Foreing - France, 78/256.

Martinho de Mello e Castro to Earl of Egremont. Figuera, 29 de abril de 1763. The National Archives - Londres, State Paper Foreing - France, 78/256.

Martinho de Mello e Castro to Earl of Egremont. Londres, 28 de abril de 1762. The National Archives - Londres, State Paper Foreing - Portugal, 89/55, folios 208-13.

Martinho de Mello e Castro to Earl of Egremont. Londres, 3 de maio de 1762. The National Archives - Londres, State Paper Foreing - Portugal, 89/55.

Martinho de Mello e Castro to Earl of Egremont. Londres, 8 de abril de 1762. The National Archives - Londres, State Paper Foreing - Portugal, 89/55, folios 178-82. 
Martinho de Mello e Castro to Earl of Egremont. Londres, 9 de dezembro 1762. The National Archives - Londres, State Paper Foreing - Portugal, 89/57.

Martinho de Mello e Castro to Earl of Egremont. Londres, 9 de outubro 1762. The National Archives - Londres, State Paper Foreing - Portugal, 89/57.

Royal instructions for the Earl of Kinnoull as Ambassador Extraordinary and Plenipotentiary of King Joseph I. Londres, 18 de janeiro de 1760. The National Archives - Londres, State Paper Foreing - Portugal, 89/52.

Secret and Separate instruction for Lord Tyrawly as Minister Plenipotentiary to Court of Portugal. Londres, 22 de fevereiro de 1752. The National Archives - Londres, State Paper Foreing - Portugal, 89/48.

Separate Instructions for the care of Kinnoull. Londres, 18 de janeiro de 1760. The National Archives - Londres, State Paper Foreing - Portugal, 89/52.

Sir H. Frankland to Earl of Egrement. Lisboa, 15 de janeiro de 1762. The National Archives Londres, State Paper Foreing - Portugal, 89/55.

Sir H. Frankland to Earl of Egrement. Lisboa, 5 de janeiro de 1762. The National Archives Londres, State Paper Foreing - Portugal, 89/55.

Sir. H. Frankland to R. Wood. Londres, 18 de julho de 1761. The National Archives Londres, State Paper Foreing - Portugal, 89/53 - folios 157-71.

W. Pitt to Earl of Kinnoull. Londres, 30 de maio de 1760. The National Archives - Londres, State Paper Foreing - Portugal, 89/52 - folios 51-61.

Archives du ministère des affaires étrangères - Paris

Correspondence du cardinal de Bernis, Ministre d'État, avec M. Paris du Verney, Conseiller d'État, depuis 1752 jusqu'em 1769, précédée d'une notice historique, 1790.

Correspondences de Portugal. Archives du ministère des affaires étrangères - Paris. Mémoires et documents - Portugal 1, folio 86.

Mémoire pour servir d'instruction au sieur comte de Merle, cornette de la première compagnie des mousquetaires de la garde du roi, allant a Lisbonne em qualité d'ambassadeur de as majesté auprès du roi de Portugal. Versailles, 15 de janvier 1759. Archives du ministère des affaires étrangères - Paris. Mémoires et documents - Portugal, 1.

Mémoire pour servir d'instruction au sieur O’Dune, allant a Lisbonne pour y résider em qualité de Ministre Plénipotentiaire du roi auprès du roi de Portugal. Versailles, 15 novembre 
1761. Archives du ministère des affaires étrangères - Paris. Mémoires et documents Portugal 1, minutes, folio 255.

Merle. Archives du ministère des affaires étrangères - Paris. Mémoires et documents Portugal, 1 - avulsos.

Biblioteca Guita e José Mindlin - São Paulo

Borrador de Antonio Gomes Ferrão Castelo Branco - cartas expedidas e recebidas de 1749 a 1759.

Question des limites du Brésil et de la Guyane Anglaise soumise a l'arbitrage de S. M. Le Roi D'Italie. Paris: Ducourtioux et Huillard, 1903.

Santa Casa de Misericórdia da Bahia-Salvador

Admissão de Pedro de Unhão Ferrão Castelo Branco à Santa Casa de Misericórdia da Bahia. Bahia, 06 de abril de 1732 - SCMBA - Tr. Ir. 504, L. 3, 355 (614v).

Fontes primárias impressas

ACCIOLI, Ignácio de Cerqueira e Silva. Memórias históricas e políticas da Bahia. Anotado por Braz do Amaral. Salvador: Imprensa Oficial, 1931. 6 vols.

ANDREONI, João António. Cultura e opulência do Brasil. São Paulo: Companhia Editora Nacional, 1967.

CALDAS, José Antonio. Notícia geral de toda esta Capitania da Bahia desde seu descobrimento até o presente ano de 1759. Salvador: Beneditina, 1951.

CÂMARA MUNICIPAL DE LISBOA - Exposição Comemorativa do Terramoto de 1755. Catálogo. Exposição realizada de 1 a 15 de Novembro de 1934, no Pavilhão de festas do Parque Eduardo VII, na cidade de Lisboa. Lisboa: Câmara Municipal, 1934.

CAPITULAÇÃO da colônia do Santíssimo Sacramento concluída a 30 de outubro de 1762. In.: Frei Cláudio da CONCEIÇÃO - Gabinete Histórico. Desde 1760 até 1762. 2. ed. Lisboa: Imprensa Nacional, tomo XV, 1881. 
CARTAS de 19 de abril de 1761. In.: Marcos Carneiro MENDONÇA - O Marquês de Pombal e o Brasil. São Paulo: Companhia Editora Nacional, 1960. pp. 114-6.

CARTAS e outras obras selectas do Marques de Pombal. Lisboa: Typographia de Costa Sanches, 1861.

CATÁLOGO dos capitães móres governadores, capitães generais, e vice-reis, que tem governado a capitania do Rio de Janeiro, desde a sua primeira fundação em 1565 até o presente anno de 1811. RIHGB, tomo 21, p. 94, 1858.

COLECÇÃO da legislação novíssima do Ultramar. Lisboa: Imprensa Nacional/Companhia Tipográfica, 1895-1913.

CONCEIÇÃO, Frei Cláudio da. Gabinete Histórico. Desde janeiro de 1755 até dezembro de 1758. 2. ed. Lisboa: Imprensa Nacional, 1881.

CORRESPONDÊNCIA do Governador e Capitão-general do Estado do Grão-Pará e Maranhão, Francisco Xavier de Mendonça Furtado (1751-1759). Organização de Marcos Carneiro de Mendonça. Brasília: Senado, 2004. 3 vols.

CORTESÃO, Jaime. Alexandre de Gusmão e o Tratado de Madrid. Rio de Janeiro: Instituto Rio Branco, 1950. 9 vols.

DISCURSO político sobre as vantagens que o reino de Portugal pode tirar da sua desgraça por ocasião do terremoto do $1^{\circ}$ de novembro de 1755. In.: CARTAS e outras obras selectas do Marques de Pombal. Lisboa: Typographia de Costa Sanches, tomo II, 1861.

DUGUAY-TROUIN, René. Relation de ce qui s'est passé pendant la campagne de Rio de Janeiro. Angers: Chez Jean Hubault, 1712.

FUNDAÇÃO CALOUSTE GULBENKIAN - Cartografia Portuguesa do Marquês de Pombal a Filipe Folque. 1750-1900: o património histórico e cartográfico do Instituto Geográfico e Cadastral. Lisboa, 1982.

GENEALOGIA baiana ou o catálogo genealógico de fr. Antônio de S. Maria Jaboatão, adaptado e desenvolvido por Afonso Costa. RIHGB, tomo 191, p. 198, abr./jun. 1946.

LUÍS Diogo Lobo da Silva, 15 de maio de 1756. Consultas do conselho ultramarino. Bahia. Códice I-8,4,7. BNRJ-DH, vol. 92, pp. 5-7.

LUÍS José Corrêa de Sá, 15 de novembro de 1756. Consultas do conselho ultramarino. Bahia. Códice I-8,4,7. BNRJ-DH, vol. 92, pp. 7-10.

MEMOIRES de monsieur du Guay Trouin, Lieutenant Géneral des Armées Navales de France et Commandeur de l'ordre Royal \& Militaire de Saint Louis, 1740.

MÉMOIRES du Duc de Choiseul. Préface et textes de liaison de Jean-Pierre Guicciardi. Notes de Philippe Bonnet. Paris: Mercure de France, 1982. 
MEMÓRIA do Abade Salema com queixas contra o conde de Merle. In.: Quadro elementar, op. cit., tomo 6, pp. 221-241.

MEMÓRIAS das principais providências que se derão no terremoto que padeceo a Corte de Lisboa no ano de 1755, ordenadas, e oferecidas à Majestade Fidelíssima de El Rey D. Joseph I, nosso senhor por Amador Patrício de Lisboa. Lisboa, 1758. Estragos do Terremoto. Vatecinio de felicidades. Sobre os habitadores da nobilíssima Villa de Setuval na jusfificada aflição em que se virão no primeiro de novembro de 1755 . Oferecido ao Ilmo. Senhor D. Antonio Luiz Caetano de Souza Marques das Minas, conselheiro de guerra, Gentil-Homem da Camara de sua Majestade Fidelíssima. Por Francisco de Santo Alberto. Lisboa, 1757.

MINISTÉRIO DA CULTURA E COORDENAÇÃO CIENTÍFICA - Marquês de Pombal: Catálogo Bibliográfico e Iconográfico, edição para a comemoração do $2{ }^{\circ}$ Centenário da morte de Marquês de Pombal. Lisboa: Biblioteca Nacional, 1982.

O JUÍZZO da verdadeira causa do terremoto... e o sacrifício simbólico do Pe. Gabriel Malagrida; seguido do fac-simíle da edição princeps desta obra (Lisboa, oficina de Manuel Soares, 1756) e outros documentos sobre a circulação da obra e punição deste jesuíta / direcção e edição de Manuel Cadafaz de Matos. Lisboa: Távola Redonda, 2008.

OLIVEIRA, Francisco Xavier de. Discurso patético sobre as calamidades presentes sucedidas em Portugal: seguimento do discurso patético. Lisboa: Frenesi, 2004.

OZANNE, Jeanne Françoise. Recueil des combats de Duguay-Trouin. N. Ozanne delineavit, Jna. Fca. Ozanne sculpsit. Paris: Chez le Sr. le Gouaz, graveur [1734?].

PARECER do conselho ultramarino. 2 de dezembro de 1756. Consultas do conselho ultramarino. Bahia. Códice I-8,4,7. BNRJ-DH, vol. 92, pp. 10-1.

PARECER do conselho ultramarino. 4 de novembro de 1750. Consultas do conselho ultramarino. Rio de Janeiro. BNRJ-DH, vol. 94, pp. 193-5.

PEDRO Dias Paes Leme, 1750. Consultas do conselho ultramarino. Rio de Janeiro. BNRJDH, vol. 94, pp. 186-92.

PRIMEIRA Carta secretíssima de Sebastião José de Carvalho e Melo, para Gomes Freire de Andrade, para servir de suplemento às instruções que lhe foram enviadas sobre a forma de execução do Tratado Preliminar de Limites, assinado em Madrid a 13 de janeiro de 1750. Lisboa, 21 de setembro de 1751.

QUADRO elementar das relações políticas e diplomáticas de Portugal com diversas potências do mundo desde o princípio da monarquia portuguesa até os nossos dias ordenado e composto pelo visconde de Santarém. Lisboa: Typ. da Academia Real das Sciencias, 1867. 20 vols. 
RECUEIL des instructions donnés aux ambassadeurs et ministres de France depuis les traités de Westphalie jusqu'a la Revolution Française publié sous les áuspices de la commission des Archives diplomatiques au Ministère des affaires étrangéres. Portugal - avec une introduction et des notes par le Vte. De Caix de Saint-Aymour. Paris, ancienne librairie Germer Baillière et Félix Alcan, éditeur, 1886.

RELATÓRIO de Antônio Luiz Gonçalves da Câmara Coutinho, governador da Bahia. 4 de julho de 1692. In.: Inês INÁCIO \& Tania Regina DE LUCA - Documentos do Brasil Colonial. São Paulo: Ática, 1993. pp. 112-5.

ROCHA PITA, Sebastião da. História da América portuguesa. Bahia: Imprensa econômica, 1878.

SEGUNDA Carta secretíssima de Sebastião José de Carvalho e Melo para Gomes Freire de Andrade, sobre os oficiais militares que se lhes enviaram, assim, nacionais, como estrangeiros, com motivo da execução do Tratado de Limites. Lisboa, 21 de setembro de 1751.

SOUTHEY, Robert. História do Brasil. Trad. Luis Joaquim de Oliveira e Castro. Rio de Janeiro: Garnier, 1862.

TOCQUEVILLE, Alexis de. De la démocratie en Amérique. Paris: Gallimard, 1961.

TRATADO llamado Pacto de família ajustado entre su Magestad Católica y su Magestad Christianíssima, em Paris à quince de agosto del año mil setecentos sessenta y uno. In.: Coleccion de los tratados de paz, alianza, comercio \&c. ajustados porla corona de España com las potencias extrangeras desde el reynado del señor don Felipe quinto hasta el presente. Madrid en la Imprenta real año de 1796.

VARNHAGEN, Francisco Adolfo. História Geral do Brasil. Antes de sua separação e independência de Portugal. Notas de Rodolfo Garcia. 8. ed. São Paulo: Melhoramentos, 1975.

\section{Referências bibliográficas}

AGUILAR PIÑAL, Francisco. Bibliografía de estudios sobre Carlos III y su época. Madrid: Consejo Superior de Investigaciones Científicas, 1988.

ALDEN, Dauril. Royal government in colonial Brazil: with special reference to the administration of the Marquis of Lavradio, viceroy, 1769-1779. Berkeley: University of California Press, 1968. 
ALENCASTRO, Luiz Felipe de. O trato dos viventes. A formação do Brasil no Atlântico Sul. São Paulo: Companhia das Letras, 2000.

AMARAL, Braz do. Fatos da vida do Brasil. Bahia: Tipografia Naval, 1941. Recordações históricas. Porto: Typ. Econômica, 1921.

AMARAL, José Álvares. Resumo Chronologico e noticioso da Província da Bahia desde o seu descobrimento em 1500. Revisto e consideravelmente annotado por J. Teixeira Barros. 2. ed. Bahia: Imprensa Oficial do Estado, 1922.

ANDERSON, Benedict. Introdução. In.: Gopal BALAKRISHNAN - Um mapa da questão nacional. Trad. Vera Ribeiro. Rio de Janeiro: Contraponto, 2000.

Nação e consciência nacional. Trad. Lólio Lourenço de Oliveira. São Paulo: Ática, 1989.

ANDERSON, Fred \& CAYTON, Andrew. The Dominion of War: Empire and Liberty in North America 1500-2000. New York: Penguin Books, 2005.

ANDERSON, Fred. Crucible of War: the seven years' war and the fate of empire in British North America, 1754-1766. London: Faber and Faber, 2001.

ARAÚJO, Ana Cristina; CARDOSO, José Luis; MONTEIRO, Nuno Gonçalves et all (Org.). O terremoto de 1755: impactos históricos. Lisboa: Livros Horizonte, 2007.

ARENDT, Hannah. Da revolução. Trad. Fernando Dídimo Vieira. Brasília: Editora da UnB, 1988.

ARGAN, Giulio. L'Europe des capitales. Genebra: Albert Skira, 1984.

ARRIGHI, Giovanni. O longo século XX. Dinheiro, poder e as origens de nosso tempo. Trad. Vera Ribeiro. Rio de Janeiro: Contraponto, 1996.

ASTON, T. H. \& PHILPIN, C. H. E. (Org.). El debate Brenner: estructura de clases agraria y desarrollo econômico en la Europa preindustrial. Trad. Isabel Moll y Paulino Irdiel. Barcelona: Editorial Crítica, 1988.

AVILÉS FERNÁNDEZ, Miguel. Carlos III y el fin del Antiguo régimen. Madrid: EDAF, 1973.

AZEVEDO, João Lúcio de. Épocas de Portugal Económico. Esboço de História. Lisboa: Clássica Editora, 1988.

O Marquês de Pombal e a sua Época. Lisboa: Clássica, 1990.

BAIARDO, Luís José. O Marquês de Pombal, Sebastião José de Carvalho e Melo, ou o Terramoto de 1755. Lisboa: Tipografia António José da Costa, 1839.

BARICKMAN, Bert. A Bahian Counterpoint: sugar, tabacco, cassava, and slavery in the Recôncavo, 1780-1860. Stanford: Stanford University Press, 1998. 
BAYLY, C. A. The birth of modern world 1780-1914. Global connections and comparisons. Oxford: Blackwell Publishing, 2005.

BELO, Conde de Campo. Governadores gerais e vice-reis do Brasil. Lisboa: Divisão de Bibliotecas e Publicações/Agência Geral das Colônias, 1935.

BÉLY, Lucien et all. Dictionaire des ministres des affaires étrangeres. Paris: Fayard, 1995.

BENZONI, G. GRIMALDI, Girolamo. In.: DIZIONARIO Biografico degli Italiani. Roma: Istituto dell'Enciclopedia Italiana, vol. LIX, 1998.

BETTENCOURT, Francisco \& CHAUDHURI, Kirti. História da Expansão Portuguesa. Lisboa: Círculo de Leitores, 1998. 5 vols.

BICALHO, Maria Fernanda. A cidade e o império. O Rio de Janeiro no século XVIII. Rio de Janeiro: Civilização Brasileira, 2003.

As noções de capitalidade no Rio de Janeiro sob a política pombalina. In.: Ana Cristina ARAÚJO; José Luis CARDOSO; Nuno Gonçalves MONTEIRO et all. (Org.). $O$ terremoto de 1755: impactos históricos. Lisboa: Livros Horizonte, 2007.

O Rio de Janeiro no século XVIII: A transferência da capital e a construção do território centro-sul da América portuguesa. (mimeo)

BILLIG, Michael. Banal nacionalism. Londres: Sage, 1995.

BLACK, Jeremy. British foreign policy in the Eighteenth century: a survey. Journal of British Studies, 26, pp. 26-53, jan. 1987.

Eighteenth century Europe. 1700-1789. London: The Macmillan Press, 1990.

Pitt the Elder. Cambridge: Cambridge University Press, 1992.

BLACKBURN, Robin. The overthrow of colonial slavery, 1776-1848. Londres: Verso, 2011.

BORGES DE BARROS, Francisco. À margem da história baiana. Bahia: Imprensa Oficial do Estado, 1934.

BOXER, Charles Ralph. The Golden Age of Brazil, 1695-1750. Berkeley: University of California Press, 1964.

- Salvador de Sá and the struggle for Brazil and Angola, 1602-1686. London: Greenwood Press, 1975.

BRAUDEL, Fernand. Civilisation materiélle, économie et capitalisme - XVe-XVIIIe siècle. Paris: Armand Colin, 1993. 3. vols.

Grammaire des civilisations. Paris: Les Éditions Arthaud, 1987.

. La Méditerranée et le monde méditerranéen à l'époque de Philippe II. 2. Destins collectifs et mouvements d'ensemble. Paris: Armand Colin, 1990. 
CAETANO, Marcelo. Do conselho ultramarino ao conselho do império. Portugal: Divisão de publicações e Biblioteca Agência das Colônias, 1943.

CALMON, Francisco M. de Góes. Vida econômico-financeira da Bahia - elementos para história de 1808 a 1899. Bahia: Imprensa Oficial do Estado, 1925.

CANNETTI, Elias. Massa e Poder. Trad. Rodolfo Krestan. Brasília: Editora UnB, 1983.

CARDOSO, Ciro. Escravo ou camponês? O protocampesinato negro nas Américas. São Paulo: Brasiliense, 1987.

CARNAXIDE, Visconde de. O Brasil na Administração Pombalina: Economia e Política Externa. São Paulo: Editora Nacional, 1940.

CARREIRA, António. As Companhias Pombalinas de Grão-Pará e Maranhão e Pernambuco e Paraíba. 2. ed. Lisboa: Editorial Presença, 1983.

CARTER, Alice Clare. The Dutch Republic in Europe in the Seven Years War. London: MacMillan, 1971.

CARVALHO, José Murilo de. A construção da ordem: a elite política imperial/Teatro de sombras: a política imperial. 2. ed. Rio de Janeiro: UFRJ/Relume-Dumará, 1996.

CHARTIER, Roger. Au bord de la falaise. L'histoire entre certitudes et inquiétude. Paris: Albin Michel, 1998.

- Cardenio entre Ceravantes et Shakespeare. Histoire d'une pièce perdue. Paris: Gallimard, 2001. Inscrire et effacer. Culture écrite et littérature (XIe-XVIIIe siècle). Paris: Gallimard, 2005.

CIDADE, Hernâni. O marquês de Pombal. O Homem e a Obra na Metrópole e no Ultramar. Lisboa: Agência Geral do Ultramar, 1963.

CLUB D'OPINIÓ ARNAU DE VILANOVA - Para entendernos - los grandes temas del debate Españha-Cataluña. Barcelona: Ariel, 2001.

COSTA E SILVA, Cândido da. Os Segadores e a Messe: o clero oitocentista na Bahia. Salvador: Edufba, 2000.

CUNHA, Pedro Octavio Carneiro da. Política e administração de 1640 a 1763. In.: Sérgio Buarque de HOLANDA - História da civilização brasileira. 1. A época colonial. 2. Administração, economia, sociedade. Rio de Janeiro: Bertrand Brasil, 1997.

. Política e administração sob os últimos vice-reis. In.: Sérgio Buarque de HOLANDA

- História da civilização brasileira. 1. A época colonial. 2. Administração, economia, sociedade. Rio de Janeiro: Bertrand Brasil, 1997. 
DAMATTA, Roberto. Carnavais, Heróis e Malandros: para uma sociologia do dilema brasileiro. Rio de Janeiro: Guanabara, 1990.

DELGADO, José Miguel. El proyecto político de Carvajal: pensamiento y reforma en tiempos de Fernando VI. Madrid: CSIC, 2001.

DIAS, Maria Odila Leite da Silva. A interiorização da metrópole e outros ensaios. 2. ed. São Paulo: Alameda, 2009.

DICKINSON, H. T. A companion to eigheteen-century Britain/Blackwell Companions to British History. London: Wiley-Blackwel, 2002.

DOBB, Maurice. A evolução do capitalismo. Trad. Manuel do Rêgo Braga. 7. ed. Rio de Janeiro: Zahar Editores, 1980.

DOMÍNGUEZ ORTIZ, Antonio. Carlos III y la España de la Ilustración. Madrid: Alianza, 1988.

DONATO, Hernâni. Dicionário das batalhas brasileiras. São Paulo: Ibrasa, 1996.

DUERR, Hans Peter. Nudez e pudor. O mito do processo civilizacional. Lisboa: Editorial Notícias, 2002.

ELEY, Geoff \& SUNY, Ronald Grigor. Introduction: from the moment of social history to the work of cultural representation. In.: Geoff ELEY - Becoming national. A reader. Oxford: Oxford University Press, 1996.

ELIAS, Norbert. A sociedade de corte. Trad. Ana Maria Alves. Lisboa: Estampa, 1987. O processo civilizador. Trad. Rui Jungmann. Rio de Janeiro: Jorge Zahar, 1994.

FALCON, Francisco José Calazans. A Época Pombalina. Política Económica e Monarquia Ilustrada. São Paulo: Ática, 1982.

FERGUSON, Niall. A lógica do dinheiro. Trad. Maria Teresa Machado. Rio de Janeiro: Record, 2007.

- The ascent of money. A financial history of the world. New York: Penguin Books, 2008.

FERRO, João Pedro. A População Portuguesa no Final do Antigo Regime (1750-1815). Lisboa: Presença, 1995.

FLORENTINO, Manolo. Em costas negras. São Paulo: Companhia das Letras, 1997.

FONSECA, João Duarte. 1755, o Terramoto de Lisboa. Lisboa: Argumentum, 2004.

FRAGINALS, Manuel Moreno. El ingenio. Complejo económico social cubano del azúcar. Barcelona: Crítica, 2001. La historia como arma y otros estúdios sobre esclavos, ingenios y plantaciones. Barcelona: Crítica, 1999. 
FRAGOSO, João \& FLORENTINO, Manolo. O arcaísmo como projeto: mercado atlântico, sociedade agrária e elite mercantil no Rio de Janeiro, 1780-1840. Rio de Janeiro: Diadorin, 1993.

FRAGOSO, João Luís Ribeiro. Homens de grossa aventura: acumulação e hierarquia na praça mercantil do Rio de Janeiro, 1790-1830. Rio de Janeiro: Arquivo Nacional, 1992.

FRAGOSO, João; BICALHO, Maria Fernanda; GOUVEIA, Maria de Fátima (Orgs.) - $O$ Antigo Regime nos trópicos: a dinâmica imperial portuguesa (séc. XVI-XVIII). Rio de Janeiro: Civilização Brasileira, 2001.

FRANCO, Maria Silvia de Carvalho. Homens livres na ordem escravocrata. São Paulo: Unesp, 1997.

FREYRE, Gilberto. Casa-Grande \& Senzala. Formação da família brasileira sob o regime da economia patriarcal. 51. ed. São Paulo: Global, 2006.

Sobrados e mucambos. Decadência do patriarcado rural e desenvolvimento urbano. Edição comemorativa de 70 anos. São Paulo: Global, 2006.

FURTADO, Celso. Formação econômica do Brasil. 27. ed. São Paulo: Publifolha, 2000.

GILROY, Paul. O Atlântico negro. Modernidade e dupla consciência. Trad. Cid Knipel Moreira. São Paulo: 34, 2008.

GINZBURG, Carlo. Mitos, emblemas, sinais. Morfologia e história. São Paulo: Companhia das Letras, 1998.

Olhos de madeira. Nove reflexões sobre a distância. São Paulo: Companhia das Letras, 2005.

O fio e os rastros: verdadeiro, falso, fictício. Trad. Rosa Freire d'Aguiar e Eduardo Brandão. São Paulo: Companhia das Letras, 2007.

GODINHO, Vitorino Magalhães. Prix et monnaies au Portugal. Paris: Armand Colin, 1955.

GOMES, Laurentino. 1808: como uma rainha louca, um príncipe medroso e uma corte corrupta enganaram Napoleão e mudaram a história de Portugal e do Brasil. São Paulo: Planeta, 2007.

GORENDER, Jacob. O escravismo colonial. São Paulo: Ática, 1990.

GOULART REIS FILHO, Nestor. Contribuição ao estudo da evolução urbana do Brasil (1500-1720). São Paulo: Pioneira, 1968.

GREENFELD, Liah. Nacionalismo. Cinco vías hacia la modernidad. Trad. Jesús Cuéliar Menezo. Madrid: Centro de Estúdios Políticos y Constitucionales, 2005.

GUILLAMÓN, Javier. Las reformas de la administración local durante el reinado de Carlos III. Madrid: Instituto de Estudios de Administración Local, 1980. 
HANDLEY, Stuart. Second Baron Tyrawley and Baron Kilmaine (1681/2-1773). In.: Oxford Dictionary of National Biography http://dx.doi.org/10.1093/ref:odnb/20634. Consultado em 10 de julho de 2011.

HANSEN, João Adolfo. A Sátira e o Engenho. Gregório de Matos e a Bahia do século XVII. 2. ed. rev. São Paulo: Ateliê Editorial, 2004.

HERRERO SUÁREZ, Henar. El monopolio de una pasión: las reales loterías en tiempos de Carlos III. Valladolid: Universidad de Valladolid, 1992.

HESPANHA, Antonio Manuel. O antigo regime. Lisboa: Estampa, 1998.

HIBBERT, Christopher. George III: A Personal History. London: Penguin, 1999.

HOBSBAWM, Eric. A era das revoluções. Europa 1789-1848. Trad. Maria Tereza Lopes Teixeira e Marcos Penchel. 16. ed. São Paulo: Paz e Terra, 2002.

HOCHSCHILD, Adam. Enterrem as correntes. Profetas e rebeldes na luta pela libertação dos escravos. Trad. Wanda Brant. Rio de Janeiro: Record, 2007.

HOLANDA, Sérgio Buarque de. Raízes do Brasil. Edição comemorativa de 70 anos. Ricardo Benzaquen de Araújo e Lília Moritz Schwarcz organizadores. São Paulo: Companhia das Letras, 2006.

HULL, Anthony. Charles III and the Revival of Spain. Washington: Rowman \& Littlefield, 1980.

JAMES, C. L. R. The Black Jacobins: Toussaint L'Ouverture and the San Domingo Revolution. Londres: Allison and Busby Limited, 1980.

JANCSÓ, István \& PIMENTA, João Paulo G. Peças de um mosaico (ou apontamentos para o estudo da emergência da identidade nacional brasileira). In.: Carlos Guilherme MOTA - A viagem incompleta. A experiência brasileira (1500-2000). Formação: Histórias. São Paulo: Senac, 2000.

JANCSÓ, István (Org.). Brasil: formação do Estado e da Nação. São Paulo: Hucitec, 2003.

. Brasil e brasileiros - Notas sobre modelagem de significados políticos na crise do Antigo Regime português na América. Estudos Avançados, n. 22 (62), 2008.

Independência no Brasil: história e historiografia. São Paulo: Hucitec, 2005.

. Na Bahia, contra o Império. História do ensaio de sedição de 1798. São Paulo:

Hucitec, 1996.

JUNCO, José Álvarez. Mater dolorosa: la idea de España em el siglo XIX. Madrid: Taurus Historia, 2002.

KENNEDY, Paul. The Rise and Fall of the Great Powers. Economic Change and Military Conflict from 1500 to 2000. New York: Random House, 1987. 
KISSINGER, Henry. Diplomacy. New York: Simon \& Schuster paperbaks, 1994.

KOSELLECK, Reinhart. Futuro Passado: contribuição à semântica dos tempos históricos. Trad. Wilma Patrícia Maas e Carlos Almeida Pereira. Rio de Janeiro: Contraponto, 2006.

KRAAY, Hendrik. "Em outra coisa não falavam os pardos, cabras, e crioulos": o "recrutamento" de escravos na guerra de Independência na Bahia. Revista Brasileira de História, São Paulo, v. 22, n. 43, pp. 109-26, 2002.

Identidade racial na política, Bahia, 1790-1840: o caso dos Henriques. In.: István JANCSÓ (Org.) - Brasil: formação do Estado e da Nação. São Paulo: Hucitec, 2003.

. Race, state and armed forces in independence-Era Brazil. Bahia, 1790s-1840s. California: Stanford University Press, 2001.

LENHARO, Alcir. As tropas da moderação: o abastecimento da Corte na formação política do Brasil - 1808-1842. Rio de Janeiro: Secretaria Municipal de Cultura, Turismo e Esportes Departamento Geral de Documentação e Informação Cultural - Divisão de Editoração, 1993. LEVER, Évelyne. Madame de Pompadour. Paris: Perrin, 2003.

LLOBERA, Josep R.. El dios de la modernidade. Barcelona: Anagrama, 1994.

LYNCH, John. El siglo XVIII. Barcelona: Crítica, 1991.

MACEDO, Jorge Borges de. O Marquês de Pombal. 1699-1782. Lisboa: Biblioteca Nacional, 1982.

MALERBA, Jurandir. A corte no exílio: civilização e poder no Brasil às vésperas da independência (1808-1821). São Paulo: Companhia das Letras, 2001.

MARCOS, Rui de Figueiredo. As Companhias Pombalinas: Contributo para a História das Sociedades por Acções em Portugal. Coimbra, 1997.

MARIZ, Vasco. Brasil-França: Relações históricas no período colonial. Rio de Janeiro: Biblioteca do Exército, 2006.

MARQUEZ, Macarena. Bárbara de Braganza. Madrid: Eila Editores, 2011.

MARX, Karl. $O$ capital. Crítica da economia política. 1. O processo de produção do capital. Trad. Regis Barbosa e Flávio R. Kothe. São Paulo: Abril Cultural, 1983.

MATTOS, Ilmar Rolhoff. O Tempo Saquarema. São Paulo: Hucitec, 1987.

MATTOSO, José (dir.). História de Portugal. Lisboa: Círculo de Leitores, vol. 4, 1993.

MATTOSO, Kátia. A opulência na Província da Bahia. In.: Luiz Felipe de ALENCASTRO História da vida privada no Brasil. Império: a corte e a modernidade nacional. São Paulo: Companhia das Letras, 1997.

Au nouveau monde: une province d'un nouvel empire: Bahia au XIX siècle. Histoire, économie et societé, 4ème trimestre, pp. 535-69, 1987. 
Bahia, século XIX: uma província no Império. Rio de Janeiro: Nova Fronteira, 1992.

- Da revolução dos alfaiates à riqueza dos baianos no século XIX: itinerário de uma historiadora. Salvador: Corrupio, 2004.

MAURO, Frédéric. Nova história e novo mundo. 3. ed. São Paulo: Perspectiva, 1973.

MAXWELL, Kenneth R. Pombal and the Nationalization of the Luso-Brazilian Economy.

The Hispanic American Historical Review, vol. 48, n. 4, pp. 608-631, nov. 1968.

. A devassa da devassa. A Inconfidência Mineira. Brasil e Portugal (1750-1808). 5. ed.

São Paulo: Paz e Terra, 2000.

. Marquês de Pombal. Paradoxo do Iluminismo. 2. ed. São Paulo: Paz e Terra, 1996.

MAZZARI, Marcus Vinicius. Apresentação. In.: Johann Wolfgang GOETHE GOETHE - Os anos de aprendizado de Wilhelm Meister. São Paulo: 34, 2006.

MCLYNN, Frank. 1759: The Year Britain Became Master of the World. London: Pimlico, 2005.

MELLO E SOUSA, Laura de. O sol e a sombra: política e administração na América portuguesa do século XVIII. São Paulo: Companhia das Letras, 2006.

MONIZ BANDEIRA, Luiz Alberto. O Feudo: a casa da Torre de Garcia d'Ávila - da conquista dos sertões à Independência. Rio de Janeiro: Civilização Brasileira, 2000.

MONTEIRO, Nuno Gonçalo. Trajetórias sociais e governo das conquistas. Notas preliminares sobre os vice-reis e governadores-gerais do Brasil e da Índia nos séculos XVII e XVIII. In.: João FRAGOSO; Maria Fernanda BICALHO; Maria de Fátima GOUVÊA - $O$ antigo regime nos trópicos: a dinâmica imperial portuguesa (séculos XVI-XVIII). Rio de Janeiro: Civilização brasileira, 2001.

MORAES, Antonio Carlos Robert. Bases da formação territorial do Brasil. O território colonial brasileiro no "longo" século XVI. São Paulo: Hucitec, 2000.

MORAES, José Geraldo Vinci de \& REGO, Mário. Conversas com historiadores brasileiros. Rio de Janeiro: 34, 2002.

MOREL, Marco. As transformações dos espaços públicos: imprensa, atores políticos e sociabilidades na cidade imperial (1820-1840). São Paulo: Hucitec, 2005.

MORSE, Richard. O espelho de Próspero: cultura e idéias nas Américas. Trad. Paulo Neves. São Paulo: Companhia das Letras, 1988.

MOTA, Carlos Guilherme. A idéia de revolução no Brasil (1789-1801): estudo das formas de pensamento. Petrópolis: Vozes, 1979.

. A viagem incompleta. A experiência brasileira (1500-2000). Formação: Histórias. São Paulo: Senac, 2000. 
- Viagem incompleta: experiência brasileira (1500-2000). A grande transição. São Paulo: Senac, 2000.

MOTTA, Marly Silva da. O Rio de Janeiro continua sendo: de cidade-capital a estado da Guanabara. Niterói: ICHF-UFF, 1997.

. O Rio de Janeiro continua sendo: de cidade-capital a estado da Guanabara. Niterói: ICHF-UFF, 1997.

O Rio de Janeiro continua sendo? Rio de Janeiro: CPDOC , 2000.

. Que será do Rio? Refletindo sobre a identidade política da cidade do Rio de Janeiro.

Tempo, Rio de Janeiro, vol. 4, pp. 146-174, 1997.

MUMDORF, Lewis. The culture of cities. Londres: Secker \& Warburg, 1940.

NOVAIS, Fernando A. Condições de privacidade na colônia. In.: Laura de MELLO E SOUZA - História da Vida Privada: o cotidiano e a vida privada na América portuguesa. São Paulo: Companhia das Letras, 1997.

. Portugal e Brasil na Crise do Antigo Sistema Colonial. 8. ed. São Paulo: Hucitec, 2005.

OLIVEIRA, Ricardo de. Política, diplomacia e o império colonial Português na primeira metade do século XVIII. História: Questões \& Debates, n. 36, pp. 251-278, 2002.

OZANAM, D. La diplomacia de Fernando VI. Correspondencia entre Carvajal y Huéscar, 1746-1749. Madrid: Escuela de Historia Moderna, Madrid, 1975.

PERES, Wilma. Do domínio à nação: os impasses da fiscalidade no processo de Independência. In.: István JANCSÓ - Brasil: formação do Estado e da Nação. São Paulo: Hucitec, 2003.

PETRIE, Charles. King Charles III of Spain. Londres, 1971.

PINHO, Wanderley. A Bahia, 1808-1856. In.: Sérgio Buarque de HOLANDA (Dir.) História Geral da Civilização Brasileira. O Brasil monárquico: dispersão e unidade. Regência. Rio de Janeiro: Bertrand Brasil, 2002.

PRADO JR, Caio. Formação do Brasil Contemporâneo. Colônia. São Paulo: Publifolha, 2000.

PRIORE, Mary del. Ritos da vida privada. In.: Laura de MELLO E SOUZA (Org.) Cotidiano e vida privada na América portuguesa. São Paulo: Companhia das Letras, 1997.

PUJOL, Jordi. Cataluña-Españha. Madrid: Edición de Ramón Pi, 1996.

RAMOS, Luís A. de Oliveira. Sob o Signo das Luzes. Lisboa: INCM, 1987.

REIS, João José \& SILVA, Eduardo. Negociação e conflito: a resistência negra no Brasil escravista. São Paulo: Companhia das Letras, 1989. 
REIS, João José. A elite baiana face aos movimentos sociais, Bahia: 1824-1840. Revista de História, São Paulo, vol. LIV, pp. 341-84, 1976.

- A morte é uma festa: ritos fúnebres e revolta popular no Brasil do século XIX. São Paulo: Companhia das Letras, 1991.

. Identidade e diversidade étnicas nas irmandades negras no tempo da escravidão.

Tempo, Rio de Janeiro, v. 2, n. 3, pp. 7-33, 1997.

. O levante dos malês na Bahia: uma interpretação política. Estudos Econômicos, v. 17, n. Especial, pp. 131-49, 1987.

Rebelião escrava no Brasil: a história do levante dos malês em 1835. Edição revista e ampliada. São Paulo: Companhia das Letras, 2003.

Um balanço dos estudos sobre as revoltas escravas da Bahia. In.: João José REIS -

Escravidão e invenção da liberdade: estudos sobre o negro no Brasil. São Paulo: Brasiliense, 1988.

RÉMOND, René. El antiguo regimen y la revolución - 1750-1815. Trad. Marco Aurelio Galmarini. Barcelona: Vicens-vives, 1980.

RIBEIRO, Darcy. O povo brasileiro. A formação e o sentido do Brasil. São Paulo: Companhia das Letras, 1995.

RIBEIRO, Gladys Sabina. A liberdade em construção. Identidade nacional e conflitos antilusos no Primeiro Reinado. Rio de Janeiro: Relume-Dumará, 2002.

RICOEUR, Paul. Temps et récit. Paris: Seuil, 1985.

RISÉRIO, Antonio. A utopia brasileira e os movimentos negros. São Paulo: 34, 2007.

ROCHA, João Cezar de Castro. "Nenhum Brasil existe”: poesia como história cultural. In.: João Cezar de Castro ROCHA (Org.) - Nenhum Brasil Existe. Pequena Enciclopédia. Rio de Janeiro: Topbooks, 2003.

RODGER, N. A. M. Command of the Ocean: A Naval History of Britain, 1649-1815. London: Penguin, 2006.

RUBIO, María José. Reinas de España. Siglos XVIII al XXI. De María Luisa Gabriela de Saboya a Letizia Ortiz. Madrid: Editorial La Esfera de los Libros, 2009.

RUSSELL-WOOD, A. J. R. Um mundo em movimento. Os portugueses na África, Ásia e América (1492-1808). Trad. Vanda Anastácio. Miraflores: Difel, 2000.

. Centros e Periferias no Mundo Luso-Brasileiro,1500-1808. Revista Brasileira de História, v. 18, n. 36, 1998. 
Governantes e agentes. In.: Francisco BETHENCOURT \& Kirti CHAUDHURI -

História da expansão portuguesa. 3. O Brasil na balança do império. Lisboa: Círculo de leitores, 1998.

RUY, Affonso. História política e administrativa da cidade de Salvador. Salvador: Beneditina, 1949.

SAES, Décio. A formação do Estado burguês no Brasil (1888-1891). Rio de Janeiro: Paz e Terra, 1985.

SAID, Edward W. Culture and imperialism. New York: Alfred Knopf, 1994.

SALGADO, Augusto A. Alves. O poder naval português no Atlântico Séculos XVI a XVIII. In.: ACTAS do Congresso Internacional Espaço Atlântico de Antigo Regime: poderes e sociedades. Lisboa, 2005.

SALGADO, Graça (Org.). Fiscais e meirinhos. A administração no Brasil Colonial. 2. ed. Rio de Janeiro: Nova Fronteira, 1985.

SANTOS, Catarina Madeira. «Goa É a Chave de Toda a Índia». Perfil Político da Capital do Estado da Índia (1505-1570). Lisboa: CNCDP, 1999.

SANTOS, Maria Helena Carvalho dos. Pombal Revisitado. Lisboa: Estampa, 1984.

SANTOS, Milton. A Natureza do Espaço. Técnica e tempo. Razão e emoção. São Paulo: Edusp, 2006.

. A urbanização brasileira. São Paulo: Edusp, 2008.

. Espace et méthode. Trad. Marie-Hélène Triercelin. Paris: Publisud, 1989.

O centro da cidade de Salvador. São Paulo: Edusp, 2008.

SCHAMA, Simon. Citizens: a chronicle of the French Revolution. New York: Alfred A. Knopf, 1990.

SCHWARCZ, Lilia Moritz; COSTA, Angela Marques da; AZEVEDO, Paulo Cesar de. A longa viagem da biblioteca dos reis: do terremoto de Lisboa à independência do Brasil. São Paulo: Companhia das Letras, 2002.

SCHWARTZ, Stuart. Burocracia e sociedade no Brasil colonial. A suprema corte da Bahia e seus juízes: 1609-1751. São Paulo: Perspectiva, 1979.

. Segredos internos: engenhos e escravos na sociedade colonial, 1550-1835. São Paulo:

Companhia das Letras, 2000.

SENNETT, Richard. Carne e pedra: o corpo e a cidade na civilização ocidental. Rio de Janeiro: Record, 2001.

_. O declínio do homem público: as tiranias da intimidade. Trad. Lygia Araujo Watanabe. São Paulo: Companhia das Letras, 1988. 
SERRÃO, José Vicente. Do Antigo Regime ao Liberalismo. 1750-1850. Lisboa: Vega, 1989. SIMMS, Brendan. Three Victories and a Defeat: The Rise and Fall of the First British Empire. London: Penguin, 2008.

SOUZA, Paulo César. A Sabinada: a revolta separatista da Bahia. São Paulo: Círculo do Livro, 1987.

STAROBINSKI, Jean. As máscaras da civilização. Trad. Maria Lúcia Machado. São Paulo: Companhia das Letras, 2001.

STEIN, Stanley J. \& STEIN, Barbara H. El apogeo del imperio: España y Nueva España en la era de Carlos III, 1759-1789. Barcelona: Crítica, 2005.

SWEEZY, Paul M. Teoria do desenvolvimento capitalista. Princípios de economia política marxista. Trad. Waltensir Dutra. 2. ed. Rio de Janeiro: Zahar Editores, 1967.

TAVARES, Luís Henrique Dias. A Independência do Brasil na Bahia. Rio de Janeiro: Civilização Brasileira, 1977.

TÉLLEZ ALARCIA, D. La supuesta anglofilia de D. Ricardo Wall. Filias y fobias políticas durante el reinado de Fernando VI. Revista de Historia Moderna. Anales de la Universidad de Alicante, 21, pp. 501-36, 2003.

. Richard Wall: light and shade of an Irish minister in Spain (1694-1777). Irish Studies Review, 11.2, pp. 123-36, aug. 2003.

TERRICABRAS, Josep-Maria. Raons i topics: catalanisme i anticatalanisme. Barcelona: La campana, 2001.

URICOECHEA, Fernando. O minotauro imperial: a burocratização do Estado Patrimonial brasileiro no século XIX. Rio de Janeiro/São Paulo: DIFEL, 1978.

VATTIMO, Gianni \& ROVATTI, P. A. Il pensiero debole. Milano: Feltrinelli, 1983.

VATTIMO, Gianni. La fine dela modernità. Milano: Garzanti, 1985.

VIANNA, Francisco José de Oliveira. Populações meridionais do Brasil. História, organização e psicologia. Populações rurais do centro sul. Paulistas, fluminenses, mineiros. Belo Horizonte: Itatiaia, 1987.

VILAR, Pierre. Cataluña en la España Moderna. Barcelona: Crítica, 1989. 3vols. Estat, Nació, Socialisme. Estudis sobre el cas espanyol. Barcelona: Curial, 1981. . Oro y moneda en la historia (1450-1920). 6. ed. Barcelona: Ariel, 1982.

VOLTES BOU, Pedro. Carlos III y su tiempo. Barcelona: Juventud, 1964. Fernando VI. Barcelona: Planeta, 1996. 
WALLERSTEIN, Immanuel. El moderno sistema mundial II: el mercantilismo y la consolidación de la economia-mundo europea, 1600-1750. Trad. Pilar López Máñez. Madrid: Siglo XXI de España editores, 1984.

WEHLING, Arno \& WEHLING, Maria José. Direito e justiça no Brasil colonial: o tribunal da Relação do Rio de Janeiro (1751-1808). Rio de Janeiro: Renovar, 2004.

WILDBERGER, Arnold. Os presidentes da Província da Bahia. Salvador: Typ. Beneditina, 1949.

WILLIAMS, Raymond. O campo e a cidade na história e na literatura. Trad. Paulo Henrique Britto. São Paulo: Companhia das Letras, 1990.

Dissertações e teses

ARAS, Lina Maria Brandão de. A Santa Federação Imperial: Bahia, 1831-1833. São Paulo, 1995. (Tese apresentada ao programa de pós-graduação do departamento de História da FFLCH-USP).

DIAS, Silvana Moreli. Cartas provincianas: a correspondência entre Gilberto Freyre e Manuel Bandeira. São Paulo, 2009. (Tese apresentada ao departamento de Literatura Brasileira da FFLCH-USP)

FERRO, Carolina Chaves. Terremoto em Lisboa, tremor na Bahia. Um protesto contra o donativo para a reconstrução de Lisboa. Niterói, 2009. (Dissertação apresentada à Universidade Federal Fluminense)

GONÇALVES, Izabela Gomes. A sombra e a penumbra: o vice-reinado do conde da Cunha e as relações entre centro e periferia no Império português (1763-1767). Niterói, 2010. (Dissertação apresentada ao departamento de História da Universidade Federal Fluminense) JUNQUEIRA, Lucas de Faria. A Bahia e o Prata no Primeiro Reinado: comércio, recrutamento e guerra cisplatina (1822-1831). Salvador, 2005. (Dissertação apresentada ao programa de pós-graduação do departamento de História da FFCH-UFBa)

LAHUERTA, Flora. Geografias em movimento: território e centralidade no Rio de Janeiro (1808-1821). São Paulo, 2010. (Dissertação apresentada ao departamento de Geografia da FFLCH-USP)

MORTON, F. W. O. The Conservative Revolution of Independence: economy, society and politics in Bahia, 1790-1840. Oxford, 1974. (Tese apresentada à Oxford University) 
NARITOMI, Joana. Herança colonial, instituições \& desenvolvimento. Um estudo sobre a desigualdade entre os municípios brasileiros. Rio de Janeiro, 2007. (Dissertação apresentada ao departamento de Economia da PUC-RIO)

SILVA, Daniel Afonso da. Histórias de Bahia, Histórias de Brasil: cinco estudos sobre a crise do primeiro reinado na Bahia (1828-1831). São Paulo, 2007. (Dissertação apresentada ao programa de pós-graduação do departamento de História da FFLCH-USP)

Outros

BALZAC, Honoré de. Le père Goriot. Paris: Librairie Générale Française, 1995.

BÍBLIA de Jerusalém. São Paulo: Paulus, 2002.

BORGES, Jorge Luis. El Aleph. Buenos Aires: La Nación, 2005.

BLOOM, Harold. Charlie Rose, Shakespeare Series: why Shakespeare? With Harold Bloom, Oskar Eustis, Michel Boyd. New York, CBS, 10/11/2011, 60 min.

CASTElO BRANCO, Camilo. Perfil do Marquês de Pombal. Porto, Porto Editora, 1962.

CERVANTES, Miguel. El ingenioso Hidalgo don Quijote de la Mancha. Barcelona: Mediasat, 2001.

CIPRIANO BARATA. Desengano ao público ou exposição dos motivos da minha arbitrária prisão na Província da Bahia (primeira parte). Rio de Janeiro: Typ. de Lessa \& Pereira, 1831.

COPOLA, Sofia. Marie Antoinette. EUA-França-Japão, 2006. 123 min.

DIAS, Clara. Marquês de Pombal. Porto: Asa, 1993.

DONNE, John. The Works of John Donne: with a memoir of his life. Londres: John Parker, 1938.

HUGO, Victor. Les Misérables. Paris: Librairie Générale Française, 1985.

KANT, Immanuel. Escritos sobre o terramoto de Lisboa. Trad. Benedith Bettencourt. Coimbra: Almedina, 2005.

MACHADO DE ASSIS. O espelho. In.: MACHADO DE ASSIS - Contos. São Paulo: Paz e terra, 1996.

PLUTARCO. Como tirar proveito de seus inimigos. Trad. Isis Borges B. da Fonseca. São Paulo: Martins Fontes, 2003.

SARAMAGO, José. O evangelho segundo Jesus Cristo. São Paulo: Companhia das Letras, 1998.

SCOLA, Ettore. La nuit de Varennes. Paris-Roma, 1982. 150min. 
SHAKESPEARE, William. The tragedy of Macbeth. Londres, s. d.

SWIFT, Jonathan. Ode to the honourable Sir William Temple. In.: The poetical words of Jonathan Swift. London: William Pickering, vol. 1, 1833.

TORRES, Antonio. O nobre sequestrador. Rio de Janeiro: Record, 2002.

VOLTAIRE - Candide, Zadig. Paris: Bibliothèque Calles, 1988. 
Anexos 
Os dados a seguir foram extraídos da Notícia geral de toda esta Capitania da Bahia desde seu descobrimento até o presente ano de 1759 (Salvador: Beneditina, 1951) de José Antonio Caldas. 
Senhores de Engenho

Bahia, 1750-1760 


\begin{tabular}{|l|}
\hline \multicolumn{1}{|c|}{ Senhores de engenho } \\
\hline Albano do Prado Pimentel \\
\hline Alexandre Gomes Ferrão \\
\hline Andre de Brito de Castro \\
\hline Anna Maria \\
\hline Anna Sutil \\
\hline Antonio Alves da Silva \\
\hline Antonio Alves Fiuza \\
\hline Antonio Borges de Barros \\
\hline Antonio Brandão \\
\hline Antonio Correa Dantas \\
\hline Antonio da Costa Rocha \\
\hline Antonio Dutra de Almeida \\
\hline Antonio Gonçalves da Rocha \\
\hline Antonio Homem de Carvalho \\
\hline Antonio Joze de Távora \\
\hline Antonio Manoel Sarmento \\
\hline Antonio Munis \\
\hline Antonio Nunes de Souza \\
\hline Antonio Pereira de Simas \\
\hline Antonio Roiz Lisboa \\
\hline Balthazar da Costa Bulcão \\
\hline Balthazar de Vasconcellos \\
\hline Balthazar de Vasconcellos \\
\hline Bartholomeo de Argollo \\
\hline Bartholomeo Soares \\
\hline Bento Ferreira Ribeiro \\
\hline Bernabe Cardozo \\
\hline Bernardo da Silveira \\
\hline Bernardo de Souza Estrella \\
\hline Bras Vieira da Rocha \\
\hline Caetano Lopes Vilas Boas \\
\hline Caetano Machado \\
\hline Catharina Borges \\
\hline Catharina do Prado \\
\hline Clemente Luis \\
\hline Constantino Velho de Moura \\
\hline Diogo Alves Campos \\
\hline Diogo Pereira do Lago \\
\hline Domingos da Costa de Almeida \\
\hline Domingos Dias Coelho \\
\hline Domingos Ferreira Leite \\
\hline Domingos Garcia de Aragão \\
\hline Egas Carlos \\
\hline Elena \\
\hline Estevão de Brito Freire \\
\hline Feliciano Gomes Viana \\
\hline Francisco Afonso Barbosa \\
\hline
\end{tabular}




\begin{tabular}{|l|}
\hline Francisco Alves da Rocha \\
\hline Francisco Cabral \\
\hline Francisco Correa de Vasconcellos \\
\hline Francisco da Rocha \\
\hline Francisco da Silva Ribeiro \\
\hline Francisco de Arahujo Silva \\
\hline Francisco de Góes Telles \\
\hline Francisco Moreira de Pinho \\
\hline Francisco Pacheco de Lima \\
\hline Francisco Teixeira \\
\hline Francisco Teles Barreto \\
\hline Gaspar Maciel \\
\hline Gonçallo Cardozo Botelho \\
\hline Gonçallo Paes de Azevedo \\
\hline Gonçallo Pinheiro da Costa \\
\hline Gonçalo Marinho \\
\hline Guiomar Cacilda de Jesus \\
\hline Hyeronimo Sodré \\
\hline Ignacio Barbalho \\
\hline Ignacio de Serqueira \\
\hline Izabel Soares \\
\hline Jeronimo da Silveira \\
\hline Jeronimo de Souza Carvalho \\
\hline Joao Bautista de Arahujo \\
\hline João Calmon \\
\hline João da Rocha \\
\hline João de Aguiar \\
\hline João de Andrade de Moura \\
\hline João Dias da Costa \\
\hline João Felis Machado \\
\hline João Felis Machado (outro) \\
\hline João Gonçalves Franco \\
\hline João Lopes Fiuza \\
\hline João Marinho \\
\hline João Paes de Azevedo \\
\hline João Pereira Alvarenga \\
\hline João Sudré Pereira \\
\hline Joao Teixeira Barboza \\
\hline João Telles Barreto \\
\hline Joze Carlos de Tavora \\
\hline Joze Correa da Gama \\
\hline Joze Correa de Arahujo \\
\hline Joze da Costa Bulcão \\
\hline Jozé Garcia Cavalcante \\
\hline Joze Gonçalves Fiuza \\
\hline Joze Pacheco da Pas \\
\hline Jozé Pacheco de Almeida \\
\hline Leandro de Oliveira \\
\hline \\
\hline
\end{tabular}




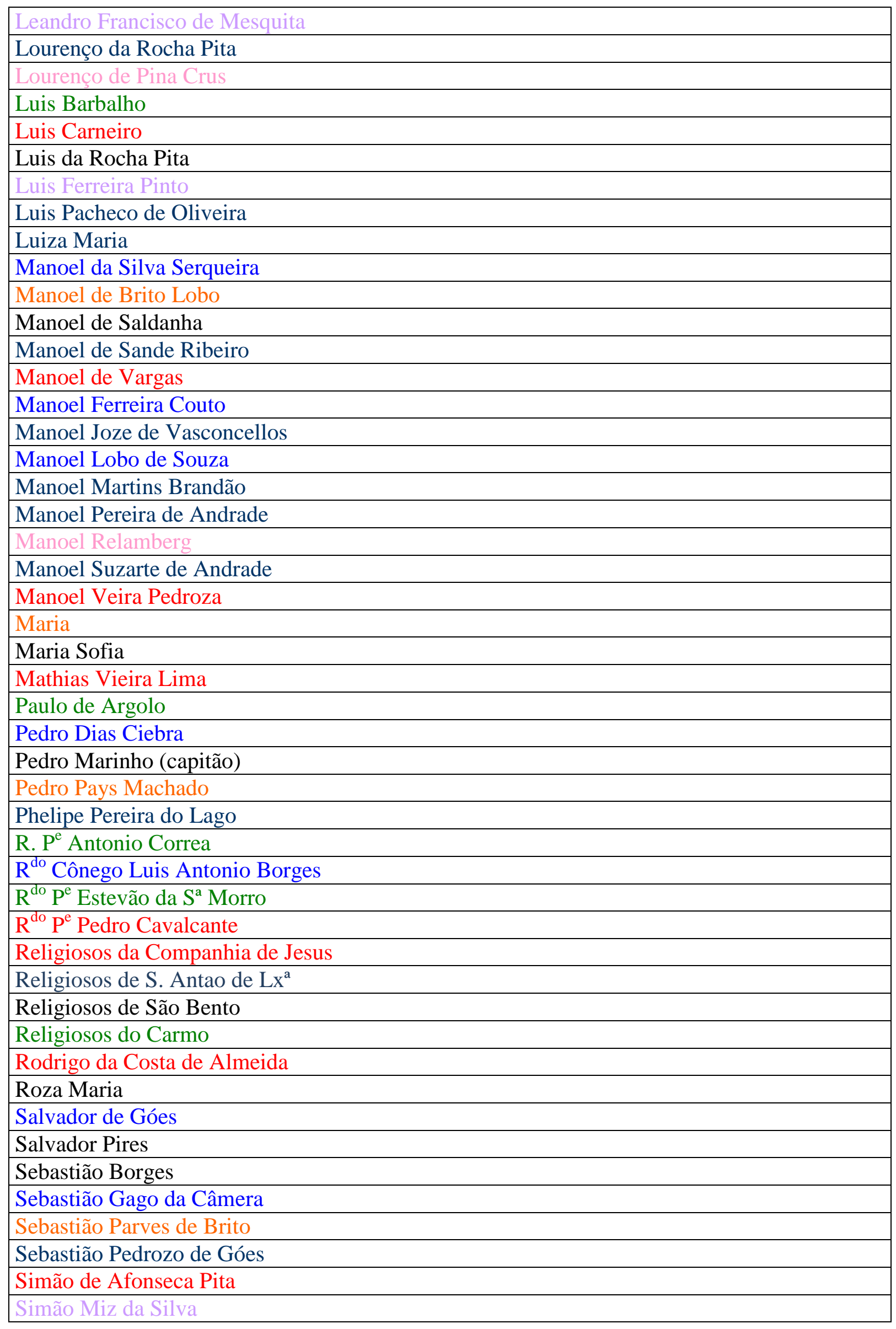


Theotonio Teixeira de Magalhães

Thereza Nunes Teles

Ursula Bezerra

Localização dos Engenhos

Santo Amaro $\square$ Matoim $\square$ Beira Mar $\square$ Mato das Seytas $\square$ Iguape

Contiguiba Guarajau Sergipe de El Rey 
Donos de alambiques

Bahia, c. 1750-1760 


\begin{tabular}{|l|}
\hline \multicolumn{1}{|c|}{ Donos de alambiques } \\
\hline Alexandre da Silva Menezes \\
\hline Amaro de Souza Coutinho \\
\hline Andre de Brito e Castro \\
\hline Andre Pires \\
\hline Anna da Graça do Espírito Santo \\
\hline Antonio Borges \\
\hline Antonio da Rocha Pita \\
\hline Antonio de Argolo dos Santos \\
\hline Antonio Dias da Costa \\
\hline Antonio Gonçalves da Rocha \\
\hline Antonio Pires Monção \\
\hline Antonio Roiz Lisboa \\
\hline Antonio Teixeira de Castro \\
\hline Clemente Luis Moreira \\
\hline Custodio de Aguiar \\
\hline Domingos Antonio Manoel de Moraes \\
\hline Domingos Joze Pires de Carvalho \\
\hline Florêncio Paes de Vasconcelos \\
\hline Francisco Borges dos Santos \\
\hline Francisco da Silveira Cunha \\
\hline Francisco de Souza Matos \\
\hline Francisco Gomes Corte Real \\
\hline Francisco Henriques \\
\hline Francisco Joze \\
\hline Francisco Luis Pereira \\
\hline Francisco Moreira de Pinho \\
\hline Francisco Vieira da Silva \\
\hline Ignacio Cardozo Jardim \\
\hline Ignacio Ribeiro de Andrade \\
\hline Ignes Duarte de Azevedo \\
\hline Jacinto Thomas de Faria \\
\hline Jacome Joze de Seixas \\
\hline Jeronimo da Maya Guimarães \\
\hline João Lopes Fiuza \\
\hline João Lourenço Velozo \\
\hline João Velho de Argolo e Azevedo \\
\hline Joze de Arahujo Vieira \\
\hline Joze Gonçalves Maya \\
\hline Joze Pires de Carvalho \\
\hline Joze Roiz \\
\hline Luis Carneiro \\
\hline Luis da Rocha Pita \\
\hline Manoel da Silva de Menezes \\
\hline \\
\hline
\end{tabular}




\begin{tabular}{|l|}
\hline Manoel de Andrade \\
\hline Manoel de Saldanha \\
\hline Manoel de Souza de Vasconcellos \\
\hline Manoel Ferreira da Rocha \\
\hline Manoel Ferreira dos Santos Maya \\
\hline Manoel Gomes \\
\hline Manoel João Coimbra \\
\hline Manoel Marques de P \\
\hline Manoel Teixeira Barboza \\
\hline Manoel Vieira Pederoza \\
\hline Maria Antonio de Vasconcelos \\
\hline Mathias Vieira \\
\hline Mônica de Arahujo Rocha \\
\hline Pantaleão Alves \\
\hline Pe Estevão da Silva Morro \\
\hline Pedro A. da Silva \\
\hline Pedro Ferreira Lemos \\
\hline Pedro Gomes Caldeira \\
\hline Sebastião Gago da Câmera \\
\hline Simão de Afonseca Pita \\
\hline Theodozio Gonçalves Silva \\
\hline Theodozio Velozo Paes \\
\hline Theotonio Vas Rabelo \\
\hline Thereza Eugenia de Menezes \\
\hline
\end{tabular}


Homens de negócios

Bahia, c. 1750-1760 


\begin{tabular}{|l|}
\hline \multicolumn{1}{|c|}{ Homens de negócios } \\
\hline Agostinho Gomes \\
\hline Alexandre Manzoni \\
\hline Andre Antonio Marques \\
\hline Antonio Alves Lima \\
\hline Antonio Alvez dos Reis \\
\hline Antonio Cardozo dos Santos \\
\hline Antonio da Costa Moreira \\
\hline Antonio da Cunha Pereira \\
\hline Antonio da Silva Pereira \\
\hline Antonio de Novais e Souza \\
\hline Antonio dos Santos Palheiros \\
\hline Antonio Duarte \\
\hline Antonio Gonsalves Viana \\
\hline Antonio Joze de Ebrea \\
\hline Antonio Lopes de Miz \\
\hline Antonio Luis do Vale \\
\hline Antonio Pereira de Arahujo \\
\hline Antonio Pinto de Carvalho \\
\hline Antonio Pires Monsam \\
\hline Antonio Rodrigues \\
\hline Antonio Rodrigues Leite \\
\hline Antonio Vaz de Carvalho \\
\hline Bento Fernandes da Galiza \\
\hline Bernardo da Silva Costa \\
\hline Caetano de Freitas Carvalho \\
\hline Cipriano da Costa Sampaio \\
\hline Clemente Joze da Costa \\
\hline David de Oliveira Lopes \\
\hline Domingos da Rocha Barros \\
\hline Domingos dos Santos Pereira \\
\hline Domingos Ribeiro \\
\hline Domingos Ribeiro Guimarães \\
\hline Domingos Roiz da Costa Braga \\
\hline Domingos Simoens da Cunha \\
\hline Faustino Luis dos Santos \\
\hline Felis de Arahujo Aranha \\
\hline Felis Manoel Dias \\
\hline Fernando Luis de Oliveira \\
\hline Florencio Lopes \\
\hline Francisco Borges dos Santos \\
\hline Francisco dos Santos Abreo \\
\hline Francisco Fernandes Vieira Guimarães \\
\hline Francisco Gomes Loures \\
\hline Francisco Gonçalves Lima \\
\hline Francisco Marques da Silva \\
\hline Francisco Rodrigues Viana \\
\hline Francisco Roiz Simões \\
\hline
\end{tabular}




\begin{tabular}{|l|}
\hline Francisco Teixeira Alvez \\
\hline Francisco Xavier da Costa \\
\hline Francisco Xavier de Almeida \\
\hline Frutuozo da Silva Henriques \\
\hline Frutuozo Vicente Viana \\
\hline Henrique Ribeiro Neves \\
\hline Jacinto Joze Coelho \\
\hline Jacome Joze de Seixas \\
\hline Jeronimo de Arahujo Pimenta \\
\hline João Alves Ferreira \\
\hline João Antonio Mansão \\
\hline João Batista Ferreira \\
\hline João Coelho de Sampaio \\
\hline João da Costa Braga \\
\hline João da Rocha \\
\hline João Dias da Cunha \\
\hline João dos Santos Horta \\
\hline João Ivo dos Santos Chaves \\
\hline João Joze de Oliveira \\
\hline João Luis da Silva \\
\hline João Luis de Deos \\
\hline João Machado de Miranda \\
\hline João Martins do Rio \\
\hline João Pereira dos Fiais \\
\hline João Roiz de Almeida \\
\hline Joaquim de Arahujo Guimarães \\
\hline Joaquim Ignacio da Cruz \\
\hline Joze Alves da Silva \\
\hline Joze Alves dos Reis \\
\hline Joze Alves Ferreira \\
\hline Joze Antunes de Carvalho \\
\hline Joze Carneiro de Campos \\
\hline Joze da Silva Costa \\
\hline Joze da Silva Tavares \\
\hline Joze de Abreo Lisboa \\
\hline Joze de Souza Reis \\
\hline Joze Fernandes Pereira \\
\hline Joze Lopes Ferreira \\
\hline Joze Lopes Viene Guimarães \\
\hline Joze Vas de Carvalho \\
\hline Joze Viciza Torres \\
\hline Joze Vieira Torres \\
\hline do. João Cardozo de Miranda \\
\hline L \\
\hline Lo. João Roiz Teixeira \\
\hline Lourenso Fernandes Crespo \\
\hline Lourenzo da Silva Niza \\
\hline Luis Coelho Ferreira \\
\hline \\
\hline
\end{tabular}




\begin{tabular}{|l|}
\hline Luis da Silva Pinto \\
\hline Manoel Alves Barboza \\
\hline Manoel Alves de Carvalho \\
\hline Manoel Alvez Monteiro \\
\hline Manoel Barboza Pereira \\
\hline Manoel Bernardo de Castro \\
\hline Manoel da Costa Lima \\
\hline Manoel da Silva Ribeiro \\
\hline Manoel Dantas Barboza \\
\hline Manoel de Souza Meira \\
\hline Manoel do Oh Freire \\
\hline Manoel Fernandes da Costa \\
\hline Manoel Gonsalves Chaves \\
\hline Manoel Ignacio Ferreira \\
\hline Manoel Joam Viana \\
\hline Manoel João Viana \\
\hline Manoel Joze de Carvalho \\
\hline Manoel Marques de Gueiros \\
\hline Manoel Teixeira Bastos \\
\hline Narciso Miz da Costa Guimarães \\
\hline Pedro Gomes Caldeira \\
\hline Pedro Rodrigues Bandeiras \\
\hline Simão Pinto de Gueiros \\
\hline Theodozio Gonçalves da Silva \\
\hline Thomas da Silva Ferrás \\
\hline Thomas Pinto Camelo \\
\hline Ventura Alves Viana \\
\hline
\end{tabular}

